FRANCISCO MARIANO DA ROCHA DE SOUZA LIMA

A FORMAÇÃO DA MINERAÇÃO URBANA NO BRASIL RECICLAGEM DE RCD E A PRODUÇÃO DE AGREGADOS

São Paulo

2013 
FRANCISCO MARIANO DA ROCHA DE SOUZA LIMA

\section{A FORMAÇÃO DA MINERAÇÃO URBANA NO BRASIL RECICLAGEM DE RCD E A PRODUÇÃO DE AGREGADOS}

Área de Concentração:

Engenharia Mineral

Orientador:

Prof. Dr. Arthur Pinto Chaves

São Paulo 
FRANCISCO MARIANO DA ROCHA DE SOUZA LIMA

\section{A FORMAÇÃO DA MINERAÇÃO URBANA NO BRASIL RECICLAGEM DE RCD E A PRODUÇÃO DE AGREGADOS}

Tese apresentada à Escola Politécnica da Universidade de São Paulo para obtenção do título de Doutor em Engenharia Mineral

Área de Concentração:

Engenharia Mineral

Orientador:

Prof. Dr. Arthur Pinto Chaves

São Paulo 
Este exemplar foi revisado e corrigido em relação à versão original, sob responsabilidade única do autor e com a anuência de seu orientador.

São Paulo, de abril de 2013.

Assinatura do autor

Assinatura do orientador

FICHA CATALOGRÁFICA

Lima, Francisco Mariano da Rocha de Souza

A formação da mineração urbana no Brasil: reciclagem de RCD e a produção de agregados / F.M.R.D. Lima. - versão corr. -São Paulo, 2013.

$154 \mathrm{p}$.

Tese (Doutorado) - Escola Politécnica da Universidade de São Paulo. Departamento de Engenharia de Minas e de Petróleo.

1. Resíduos de construção (Reciclagem) 2. Reciclagem de resíduos urbanos 3. Sustentabilidade I. Universidade de São Paulo. Escola Politécnica. Departamento de Engenharia de Minas e de Petróleo II. t. 


\section{Universidade de São Paulo}

\section{RELATÓRIO DE DEFESA}

Aluno: 3134 - 5960971 - 2 / Página 1 de 1

Relatório de defesa pública de Tese do(a) Senhor(a) Francisco Mariano da Rocha de Souza Lima no Programa: Engenharia Mineral, do(a) Escola Politécnica da Universidade de São Paulo.

Aos 07 dias do mês de março de 2013, no(a) realizou-se a Defesa da Tese do(a) Senhor(a) Francisco Mariano da Rocha de Souza Lima, apresentada para a obtenção do título de Doutor intitulada:

"A formação da mineração urbana no Brasil: reciclagem de RCD e a produção de agregados"

Após declarada aberta a sessão, o(a) Sr(a) Presidente passa a palavra ao candidato para exposição e a seguir aos examinadores para as devidas arguições que se desenvolvem nos termos regimentais. Em seguida, a Comissão Julgadora proclama o resultado:

$\begin{array}{llll}\text { Nome dos Participantes da Banca } & \text { Função } & \text { Sigla da CPG } & \text { Resultado } \\ \text { Arthur Pinto Chaves } & \text { Presidente } & \text { EP - USP } & \text { APROVADO } \\ \text { Wanda Maria Risso Günther } & \text { Titular } & \text { FSP - USP } & \text { APROVADO } \\ \text { Manoel Rodrigues Neves } & \text { Titular } & \text { EP - USP } & \text { A PROVADO } \\ \text { Yara Kulaif } & \text { Titular } & \text { Externo } & \text { APROVADO } \\ \text { Jose Renato Baptista de Lima } & \text { Suplente } & \text { EP - USP } & \text { APROVADO }\end{array}$

Resultado Final: APDOVADU

Parecer da Comissão Julgadora *

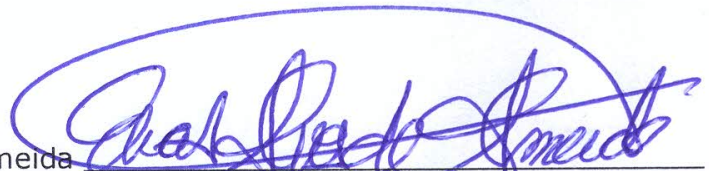
Eu, Elias Alves de Almelda

, lavrei a presente ata, que assino juntamente

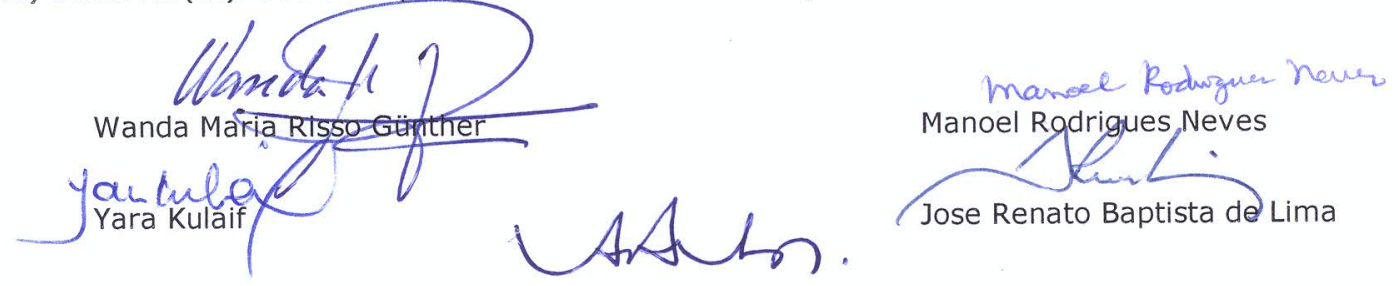

Arthur Pinto Chaves

Presidente da Comissão Julgadora

* Obs: Se o candidato for reprovado por algum dos membros, o preenchimento do parecer é obrigatório.

A defesa foi homologada pela Comissão de Pós-Graduação em $11 / 03 / 13$ título de Doutor em Ciências obtido no Programa Engenharia Mineral.

e, portanto, o(a) aluno(a) faz jus ao

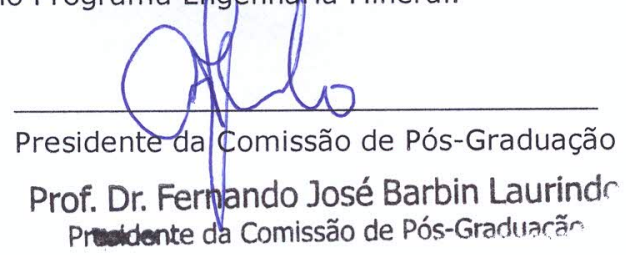




\section{DEDICATÓRIA}

A memória de meus pais Salvador e Terezinha 


\section{AGRADECIMENTOS}

Agradeço a todos que de alguma forma sugeriram ideias, incentivaram caminhos e criticaram propostas deste estudo interdisciplinar.

Agradeço ao departamento de Minas da Escola Politécnica pela abertura em acolher esta tese. De modo especial, ao Dr. Arthur Pinto Chaves, meu orientador e conselheiro nas horas difíceis. A sua visão ampla da tecnologia mineral transcende ao Tratamento de Minérios. A exemplo dos pioneiros e clássicos tratamentistas que se perguntavam acerca da viabilidade do processo que tinham criado ou aperfeiçoado, professor Arthur me indicou o caminho para desenhar a viabilidade da indústria recicladora de RCD no Brasil.

Agradeço ao CETEM que proporcionou essa experiência extraordinária de tratar e manipular centenas de amostras de RCD armazenados em volumosos big bags por meses na sua área de estocagem, na usina piloto e laboratórios. Em especial, ao colega Salvador de Almeida, coordenador do projeto FINEP HABITARE (2004) "Aperfeiçoamento do processo de reciclagem da fração mineral dos resíduos de construção e demolição". Ao colega Lauro Norbert da Costa, que supervisionou o trabalho das amostras na planta piloto e nos seus laboratórios. Agradeço aos técnicos Marcelo Andrade e Leonardo Silva Santos e ao auxiliar técnico Wagner Braz Gomes, pela dedicação em toda fase de processamento dessas amostras.

Agradeço ao Dr. Vanderley M. John e ao Dr. Sérgio Ângulo, professores da Engenharia Civil da Escola Politécnica da USP e colegas responsáveis pela parte de engenharia civil da pesquisa acima. Em especial, ao Dr. Sérgio Ângulo, parceiro em muitas visitas técnicas nas usinas brasileiras, usinas na Alemanha e na Holanda. A eles devo meus conhecimentos nesta área. Agradeço à Dra. Carina Ulsen, professora da Engenharia de Minas, que participou da elaboração dos resultados da referida pesquisa. Muito importante foi a participação do professor Paulo Cesar Gomes da Universidade Federal de Alagoas que realizou com seus alunos amostragem na cidade de Maceió. Agradeço a bibliotecária Cristina Martinez Bonésio, sempre simpática e solícita para atender às demandas dos alunos do PMI. 
Agradeço ao Dr. Mauro Wanderley Lima da COMLURB-RJ pelos valiosos conselhos e ao André Felipe Campos de Andrade, diretor da empresa Ambiente Responsável, pelas informações de dentro da indústria recicladora de RCD brasileira.

Agradeço à minha família maravilhosa que me suportou neste período. A minha esposa Ana cujo convívio me deu tranquilidade espiritual e cuja alegria me animou nos momentos adversos. Aos meus amados João, Diogo, Lucas e Guilherme, cada um traçando seu caminho, exemplos de filhos que me dão muito orgulho. Ao meu irmão Evandro, ex-professor da Engenharia Elétrica da UNB incentivador da minha carreira de pesquisador por universos que ele já alcançou nos seus trabalhos. 
"The biggest problem is not to let people accept new ideas, but to let them forget the old ones"

\section{Lord Keynes}

"A dificuldade não está em aceitar as ideias novas, mas livrar-se das antigas." Lord Keynes 


\section{RESUMO}

A nova Política Nacional de Resíduos Sólidos no Brasil, consubstanciada na lei 12305 /2010, possibilita o emprego de instrumentos econômicos para o fortalecimento de um mercado de agregados reciclados ainda nascente, no qual a maior parte dos resíduos de construção e demolição (RCD) ainda não é reciclada.

Este trabalho tem fundamentos técnicos em duas áreas do conhecimento: a engenharia mineral e a construção civil. $\mathrm{Na}$ área mineral, será analisado o tratamento do RCD, processado como um minério. Na cadeia da construção civil, o foco é o uso dos agregados reciclados obtidos a partir dos resíduos da construção e demolição, que permite a valorização do RCD como insumo para estes agregados.

O conceito de mineração urbana diz respeito à procura e ao processo de tratamento dos RCDs como matéria prima para o mercado de agregados reciclados que se formou no marco regulatório da resolução CONAMA 307 de 2002.

Neste mercado de agregados reciclados nascente, usa-se o conceito de Indústria Recicladora Emergente para traçar as possíveis estratégias para alcançar o nível qualitativo dos produtos de indústrias recicladoras maduras, localizada nos países pós-industriais.

Para dar conta da complexidade de ações da gestão dos RCDs no novo marco regulatório, empregou-se a modelagem dinâmica para os modelos de Custo Benefício em São Paulo, Macaé e Maceió e de Viabilidade da implantação de plantas de reciclagem na cidade de Macaé. A modelagem baseia-se no trabalho empírico de amostragem do RCD das três cidades brasileiras e em visitas a plantas de reciclagem no Brasil e no exterior

Os resultados obtidos mostram:

1) A heterogeneidade das cidades amostradas no tocante a qualidade do RCD originários de distintos processos de urbanização;

2) O modelo de Custo - Benefício para as três cidades mostra que os benefícios superam os custos na seguinte ordem: São Paulo, Macaé e Maceió; 
3) Plantas móveis de reciclagem são mais viáveis do que as fixas na cidade de Macaé;

4) A região de São Paulo, devido ao maior volume de RCD e maiores estímulos à reciclagem, é a única entre as três que não precisa de subsídios;

5) O modelo de viabilidade mostra que a qualidade do resíduo tem considerável influência na viabilidade das empresas de reciclagem;

6) Os fatores mais sensíveis ao modelo de viabilidade são nesta ordem: o valor cobrado pelo terreno, a taxa cobrada na entrada do RCD na planta de reciclagem, os custos de operação da planta e os impostos em vigor. 


\begin{abstract}
The new National Policy of Solid Waste in Brazil (Política Nacional de Resíduos Sólidos) based on the law 12305/2010, allows the use of economic instruments for the strengthening of the market of recycled aggregates still nascent, where the major part of its construction and demolition waste $(C D \& W)$ is not recycled yet

This work has technical roots in two knowledge fields: mining and construction. In the mining field it will be analyzed the CD\&W treatment, processed as an ore. In the construction chain the focus will be at the application of the recycled aggregates obtained, that allows the valorization of the CD\&W as a raw material of these aggregates.
\end{abstract}

The concept of urban mining refers to the searching and the process of treating the $\mathrm{CD} \& \mathrm{~W}$ as raw material for the market of recycled aggregates formed in the regulatory framework of CONAMA Resolution 307.

In this nascent market for recycled aggregates we use the concept of recycling emerging industry and determined possible strategies to reach the quality level of the products of recycling industries located in mature post-industrial countries.

To solve the complexity of the inherent management actions of CD\&W in the new regulatory framework, it was employed dynamic modeling models of Cost Benefit analysis in Sao Paulo, Macaé and Maceió and also Feasibility models to implement recycling plants in the city of Macaé. The modeling is based on the empirical work of CD\&W sampling of the three Brazilian cities and visits to recycling plants in Brazil and abroad.

The results show:

1) The heterogeneity of the cities surveyed regarding the quality of the CD\&W due to the different processes of urbanization;

2) The model of Cost - Benefit for the three cities shows that the benefits are greater than the costs in the following order: São Paulo, Macaé, Maceió;

3) In the city of Macaé, recycling mobile plants are more economic viable; 
4) The region of Sao Paulo, due to higher volume and higher RCD incentives recycling, is the only one among the three which do not need subsidies;

5) The feasibility model shows that the difference in qualities of the waste has considerable influence on the viability of recycling companies;

6) The most sensitive factors in the viability model are in this order: the amount charged for the land, the tax fee into the recycling plant, the plant's operational costs and the taxes. 


\section{LISTA DE ILUSTRAÇÕES}

Figura 2.1 - Municípios, total e com serviço de manejo de resíduos sólidos, por natureza dos serviços, segundo os grupos de tamanho dos municípios e a densidade populacional de 2008 .

Figura 2.2 - Processamento de resíduos por parte das pedreiras.................................. 14

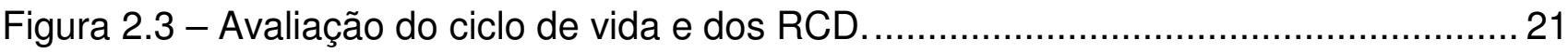

Figura 3.1 - Pátio de recepção de RCD cimentício e RCD cerâmico.................................... 31

Figura 3.2 - (a) Ambiente aberto, catação em esteira (Usina da CEMARA, Americana-SP);

(b) Ambiente fechado, com esteira e abatimento de poeira (Usina da AMAND,

Dresden, Alemanha) ............................................................................ 32

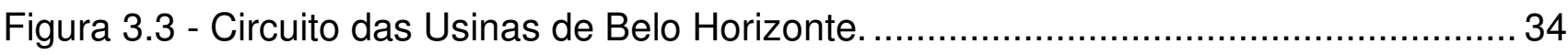

Figura 3.4 - Detalhes da Usina BR-040: (a) escalpe/britador martelo e ao fundo britador cônico (secundário); (b) produto na forma de bica corrida e ao fundo, na última pilha, aparece a brita reciclada. 34

Figura 3.5 - Fluxograma de processamento da Amand, Dresden, Maxener Strasse. Os números acima são as dimensões mínima e máxima $(\mathrm{em} \mathrm{mm})$ dos produtos da

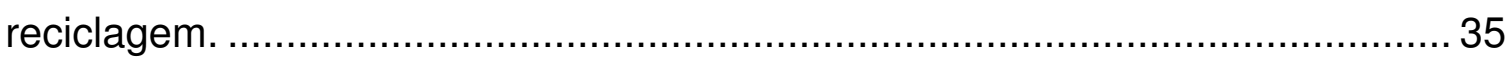

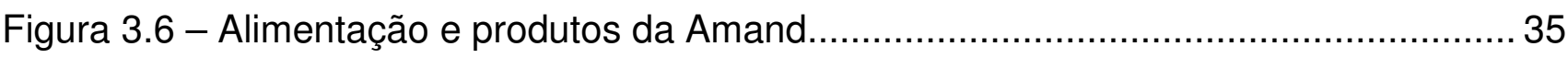

Figura 3.7 - Jigues da Deisl-Beton, Salzburg, Áustria.................................................... 36

Figura 3.8 - Circuito típico da indústria recicladora madura existente na Alemanha e Holanda para obtenção de brita de concreto.

Figura 3.9 - Circuitos típicos da indústria recicladora emergente em países como Brasil e China para produção de bica corrida e rachão. 38

Figura 4.1 - Diagrama dos ensaios de sink and float com as densidades de corte. 42

Figura 4.2 - Massa mínima representativa da amostra em função do teor de materiais orgânicos leves e a dimensão máxima dos fragmentos. 45

Figura 4.3 - Vista da área do Babal, na cidade de Macaé.............................................. 48

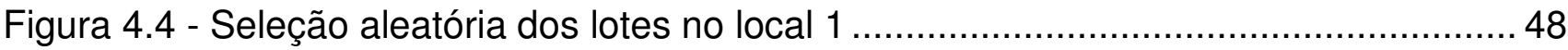

Figura 4.5 - Seleção aleatória dos lotes no local 2 ................................................... 49

Figura 4.6 - Seleção aleatória dos lotes no local 3 ....................................................... 49

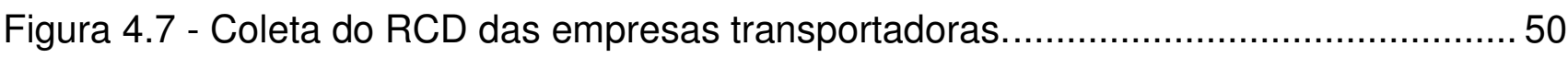

Figura 4.8 - Local de redução e preparação de amostras na cidade de Macaé...................51 
Figura 4.9 - Redução do tamanho do material no lote, através do martelete pneumático (a), e catação dos materiais indesejáveis (b).

Figura 4.10 - Procedimento de redução do tamanho e homogeneização da amostra. 52

Figura 4.11 - Redução de amostra por padejamento alternado, empregando retroescavadeira. 52

Figura 4.12 - Procedimento de formação das pilhas alongadas prismáticas dos lotes de RCD mineral. 53

Figura 4.13 - Amostras coletadas de Macaé armazenadas no Centro de Tecnologia Mineral. 54

Figura 4.14 - ATT Base Ambiental, na cidade de São Paulo. 55

Figura 4.15 - Localidades de coleta de amostras e suas frequências de ocorrências. Os percentuais da origem do RCD foram obtidos através das guias de transporte das caçambas. 55

Figura 4.16 - Procedimento de redução e preparação de amostras. 57

Figura 4.17 - Síntese da classificação visual dos lotes de Macaé: a) cinza e vermelho e b) concreto.

Figura 4.18 - Presença de materiais indesejáveis e contaminantes nos lotes de RCD mineral de Macaé.

Figura 4.19 - Amostras do RCD mineral de São Paulo: (a) origem (frequência); (b) presença de concreto/rocha. 66

Figura 4.20 - Presença de materiais indesejáveis e contaminantes nos lotes de RCD mineral de São Paulo.

Figura 4.21 - Distribuição granulométrica do RCD para diversas caçambas..................... 68

Figura 4.22 - Esquema da caracterização da composição para as três cidades ................ 69

Figura 4.23 - Fluxograma geral das atividades de caracterização dos lotes. 71

Figura 4.24 - Pilhas alongadas da fração menor que $25,4 \mathrm{~mm}$ e da fração menor que 4,8 $\mathrm{mm}$.

Figura 4.25 - (a) Peneirador vertical inclinado, escala piloto e (b) peneirador vibratório horizontal.

Figura 4.26 - Peneiramento a úmido com peneiras circulares 73

Figura 4.27 - Cone de separação em meio denso (a) e desenho esquemático do funcionamento (b) 74

Figura 4.28 - Distribuição por densidade dos lotes que compõem os grupos de qualidade, RCD Macaé. 
Figura 4.29 - Distribuição por densidade dos grupos de qualidade, RCD Macaé.

Figura 4.30 - Distribuição por densidade dos lotes que compõem os grupos de qualidade, RCD Maceió.

Figura 4.31 - Distribuição por densidade dos grupos de qualidade, RCD Maceió. 78

Figura 4.32 - Massa acumulada por fração granulométrica, lotes da $1^{\underline{a}}$ amostragem, Macaé. 79

Figura 4.33 - Massa acumulada por fração granulométrica, lotes da $2^{\mathrm{a}}$ amostragem, Macaé.

Figura 4.34 - Distribuição granulométrica média da cidade de Macaé. 80

Figura 4.35 - Massa acumulada por fração granulométrica, lotes (1 a 26) de São Paulo (primeira amostragem).

Figura 4.36 - Massa acumulada por fração granulométrica, lotes (1 a 26) de São Paulo (segunda amostragem) 82

Figura 4.37 - Distribuição granulométrica média da cidade de São Paulo. 83

Figura 4.38 - Massa acumulada por fração granulométrica, lotes de Maceió 84

Figura 4.39 - Distribuição granulométrica média na cidade de Maceió. 84

Figura 4.40 - Distribuição granulométrica da fração -63 mm, após o escalpe. 86

Figura 4.41 - Teor de contaminantes dos lotes de RCD da $1^{\text {a }}$ amostragem, Macaé. 87

Figura 4.42 - Teor de contaminantes dos lotes de RCD da $2^{\text {a }}$ amostragem, Macaé. 87

Figura 4.43 - Teores médios de contaminantes e valores limites, Macaé. 88

Figura 4.44 - Contaminantes por intervalo granulométrico, Macaé. 88

Figura 4.45 - Distribuição de contaminantes nos lotes de Macaé..... 89

Figura 4.46 - Distribuição de densidade dos agregados graúdos, lotes de Macaé. 90

Figura 4.47 - Distribuição média de densidade dos agregados graúdos, lotes de Macaé.. 91

Figura 4.48 - Distribuição dos lotes de alta qualidade dos lotes de Macaé. 91

Figura 4.49 - Distribuição de densidade dos agregados graúdos, lotes de São Paulo....... 92 Figura 4.50 - Distribuição média de densidade dos agregados graúdos, lotes de São Paulo.

Figura 4.51 - Distribuição dos lotes de alta qualidade dos lotes de São Paulo 93

Figura 4.52 - Massa específica aparente $x$ densidade, fração -25,4 +4,8 mm, São Paulo.. 93 Figura 4.53 - Distribuição de densidade dos agregados graúdos, lotes de Maceió............ 94

Figura 4.54 - Distribuição de densidade dos agregados graúdos, lotes de Maceió............ 95

Figura 4.55 - Distribuição dos lotes de alta qualidade dos lotes de Maceió. ....................... 95

Figura 4.56 - Resumo das qualidades das três cidades 
Figura 5.1 - Elementos básicos na modelagem de sistemas dinâmicos. 99

Figura 5.2 - Modelagem como um processo interativo.

Figura 5.3 - Ciclo simplificado de consumo e descarte de agregados na Construção Civil. 101

Figura 5.4 - Modelo dinâmico 1 para análise de custo-benefício da reciclagem nas cidades 105

Figura 5.5 - Densidade populacional como a maior influência na quantidade de RCD gerada em cada região.

Figura 5.6 - Efeito do preço cobrado na entrada (a) e da quantidade que é reciclada (b) sobre os percentuais.

Figura 5.7 - Resultado simulado do espaço disponível para descarte para cada cenário na cidade de Macaé.

Figura 5.8 - Resultado simulado do custo total ao meio ambiente com a ilegalidade para cada cenário considerado na cidade de Macaé. 114

Figura 5.9 - Resultado simulado do valor acumulado de subsídio nos três cenários considerados para Macaé. 115

Figura 5.10 - Resultado simulado da relação custo benefício para cada cenário da taxa de entrada na planta de reciclagem em Macaé.(1-5,00R $\$ / t ; 2-10,00 R \$ / t$, 3$5,00 \mathrm{R} \$ / \mathrm{t})$. 116

Figura 5.11 - Relação custo-benefício do gerenciamento do RCD para as três cidades. 1Macaé, 2-São Paulo, 3-Maceió 119

Figura 5.12 - Ocupação de um aterro virtual com a mesma área para as três cidades. ... 120 Figura 5.13 - Custo total proveniente do descarte ilegal nas malhas urbanas nas três cidades. 121

Figura 5.14 - Subsídio acumulado nas três cidades ao longo dos 20 anos com suas plantas de reciclagem. 121

Figura 5.15 - "Circuitos emergentes" simplificado de beneficiamento nas plantas de reciclagem no Brasil. 124

Figura 5.16 - Exemplo de planta móvel de reciclagem de RCD. 125

Figura 5.17 - Modelo dinâmico 2 proposto para análise de viabilidade econômica de usinas de reciclagem. 128

Figura 5.18 - Lucro anual antes do Imposto de Renda para cada um dos cenários considerados na cidade de Macaé 134

Figura 5.19 - Valor Presente Líquido em cada cenário em Macaé 135 
Figura 5.20 - Resultado do VPL simulado com redução de imposto e terreno para as plantas fixas e móveis em Macaé................................................................. 137 


\section{LISTA DE TABELAS}

Tabela 2.1 - Município com ou sem acesso a serviços de limpeza e/ou coleta de lixo. 10

Tabela 2.2 - Municípios com e sem serviço de manejo de RCD e o tipo de processamento dos resíduos.

Tabela 2.3 - Forma de disposição do RCD 11

Tabela 3.1 - Composição do RCD em alguns países. 25

Tabela 3.2 - Composição do RCD no Brasil. 25

Tabela 4.1 - Principais áreas de deposições irregulares de RCD da cidade de Macaé 47

Tabela 4.2 - Coleta privada do RCD por empresa de caçambas estacionárias, por dia, na cidade de Macaé 47

Tabela 4.3 - Classificação visual do RCD mineral antigo de Macaé 60

Tabela 4.4 - Classificação visual do RCD mineral antigo de Macaé 61

Tabela 4.5 - Classificação visual e da origem dos lotes da cidade de São Paulo. 64

Tabela 4.6 - Lotes que compõem os grupos de qualidade, RCD Macaé. 76

Tabela 4.7 - Lotes que compõem os grupos de qualidade, RCD Maceió. 77

Tabela 5.1 - Resumo das premissas consideradas para o modelo 1 112

Tabela 5.2 - Valores aproximados dos subsídios para cada cenário 115

Tabela 5.3 - Dados de entrada pesquisados para as três cidades para a aplicação do modelo 1.

Tabela 5.4 - Equações dos percentuais determinadas a partir dos valores iniciais pesquisados e espectativas de comportamento nos 20 anos.

Tabela 5.5 - Subsídios acumulados em cada cidade ao longo dos 20 anos. 122

Tabela 5.6- Estimativa de custos para as versões de plantas de reciclagem estudadas. . 126 Tabela 5.7 - Composição dos resíduos de alta e média qualidade na cidade analisada. . 129 Tabela 5.8 - Tabela de preços médios de venda dos agregados reciclados em Macaé ... 132 Tabela 5.9 - Cenários considerados na simulação do modelo de viabilidade econômica para a cidade de Macaé. 133

Tabela 5.10- VPL e Payback dos resultados simulados 135

Tabela 5.11 - Cenários das propostas de solução para a viabilidade das plantas com circuito emergente em Macaé 


\section{SIGLAS}

ABNT- Associação Brasileira de Normas Técnicas

ABRECON - Associação Brasileira para a Reciclagem dos Resíduos da Construção Civil e Demolição

ACV - Análise do Ciclo de Vida

ATT - Área de Triagem e Transbordo

CETEM - Centro de Tecnologia Mineral

CONAMA - Conselho Nacional do Meio Ambiente

COMLURB - Companhia Municipal de Limpeza Urbana

PNRS - Política Nacional de Resíduos Sólidos

PNSB - Pesquisa Nacional de Saneamento Básico

RCD - Resíduos da Construção e Demolição

RCC- Resíduos da Construção Civil

RSU- Resíduo Sólido Urbano

UFBA - Universidade Federal da Bahia

USP- Universidade de São Paulo

UTE - Usina Termoelétrica 


\section{SUMÁRIO}

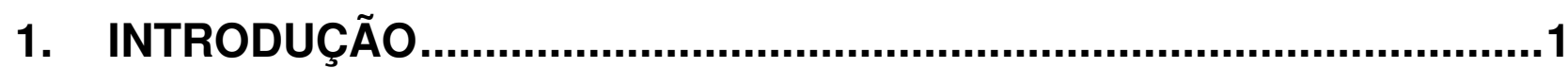

1.1 OBJETIVOS DA PESQUISA ……………………………………………....

1.2 A REVISÃO DA BIBLIOGRAFIA ............................................................

1.3 PROPOSTA INOVADORA E ESTRUTURA DA TESE...................................

2. GESTÃO DE RESÍDUOS SÓLIDOS E A MINERAÇÃO URBANA.........7

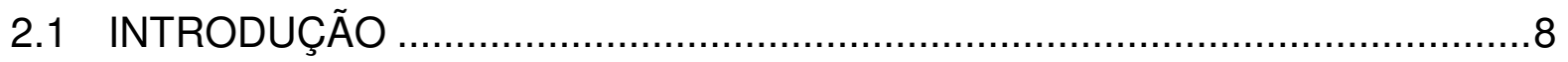

2.2 O MERCADO DE RCD EM FORMAÇÃO ..................................................11

2.3 LEGISLAÇÃO E CICLO DO PRODUTO ………………………………......16

2.3.1 A mudança do marco regulatório na área ambiental.........................16

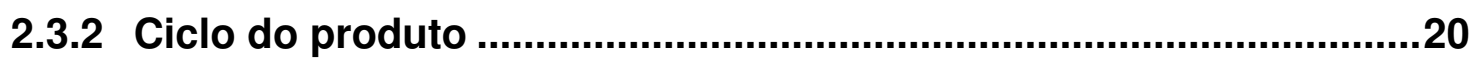

3. A INDÚSTRIA RECICLADORA EMERGENTE E A MADURA.............22

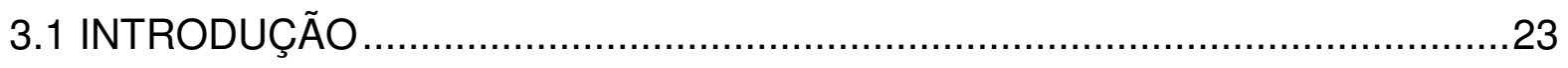

3.126

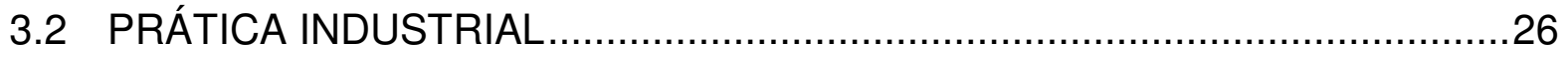

3.2.1 A área da engenharia civil .........................................................26

3.2.2 A área da engenharia mineral ........................................................29

3.3 COMPARAÇÃO DOS FLUXOGRAMAS DE OPERAÇÃO ENTRE AS RECICLADORAS NA INDÚSTRIA RECICLADORA EMERGENTE E NA

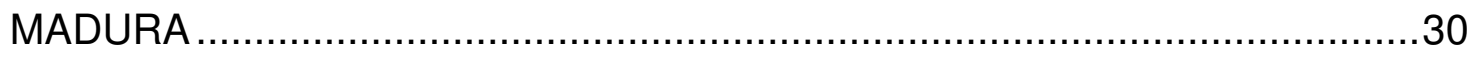

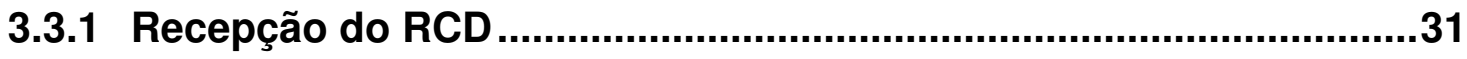

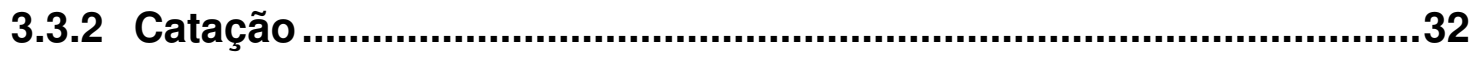

3.4 ESCALPE + BRITAGEM + PENEIRAMENTO: COMPARAÇÃO DAS PLANTAS BH-BR-04 E AMAND EM DRESDEN NA ALEMANHA ..................32

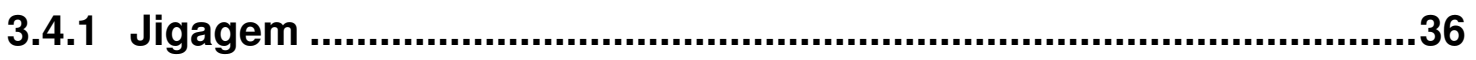

3.4.2 Comparação esquemática entre circuitos típicos da indústria

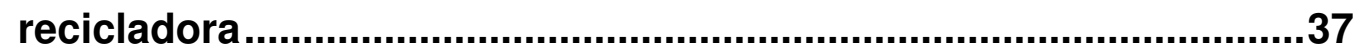

4. TRABALHO EXPERIMENTAL .......................................................40 
4.1 INTRODUÇÃO

4.2 AMOSTRA REPRESENTATIVA DOS RCDS DE MACEIÓ, SÃO PAULO E MACAÉ E ANÁLISE DA SUA VARIABILIDADE..........................................43

4.2.1 Procedimentos adotados: ................................................................43

4.2.2 Definição da Amostra representativa.............................................43

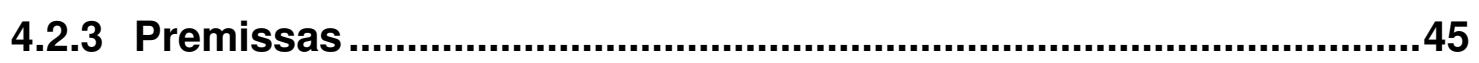

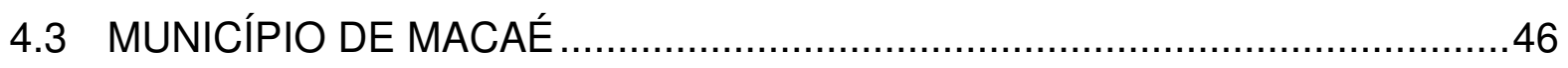

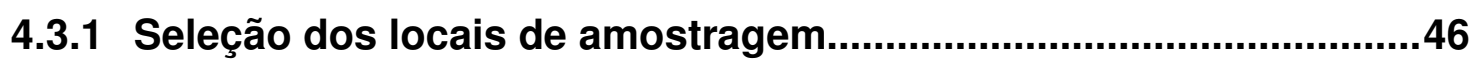

4.3.2 Critérios de classificação dos lotes ...............................................50

4.3.3 Redução e preparação das amostras.............................................50

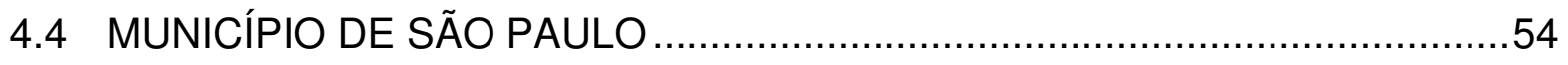

4.4.1 Seleção dos locais de amostragem.................................................54

4.4.2 Critério de classificação dos lotes ..................................................55

4.4.3 Redução e preparação das amostras...............................................56

4.5 MUNICÍPIO DE MACEIÓ.........................................................................57

4.5.1 Características da área de estudo ..................................................57

4.5.2 Seleção dos locais de amostragem.................................................58

4.5.3 Critério de classificação dos lotes ................................................59

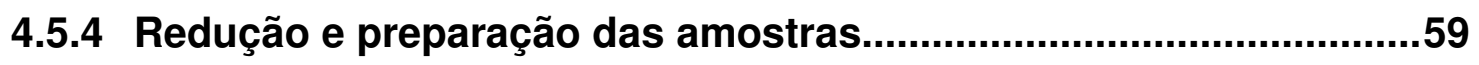

4.6 CLASSIFICAÇÃO DOS LOTES E SUA VARIABILIDADE.............................59

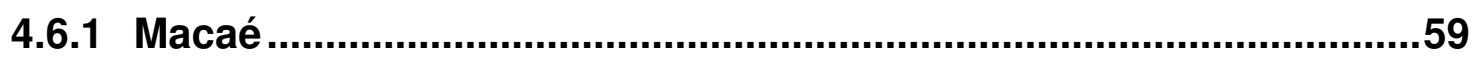

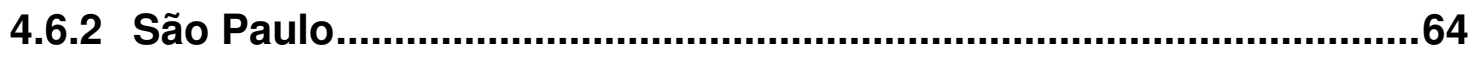

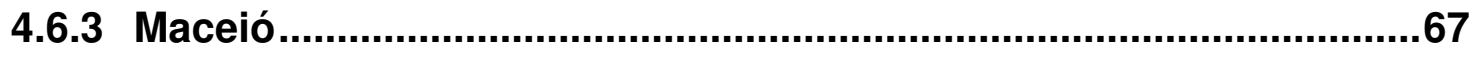

4.6.4 $O$ balanço de massa dos materiais indesejáveis e a separação visual do RCD em classes............................................................67

4.7 CARACTERIZAÇÃO DOS RCD E AGREGADOS REGIONAIS ......................70

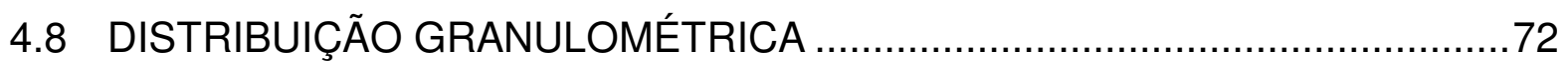

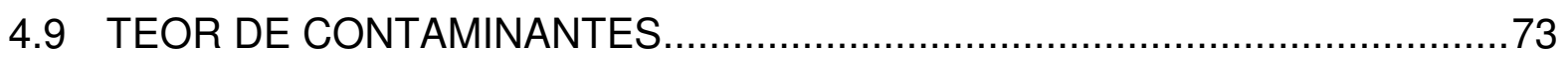


4.11 CLASSIFICAÇÃO DOS LOTES DE RCD PELA DISTRIBUIÇÃO DE DENSIDADE.

4.12 COMPOSIÇÃO DOS LOTES NOS GRUPOS DE QUALIDADE. 75

4.12.1 Macaé .76

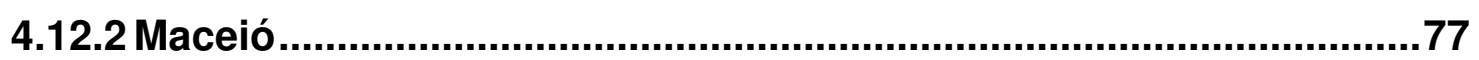

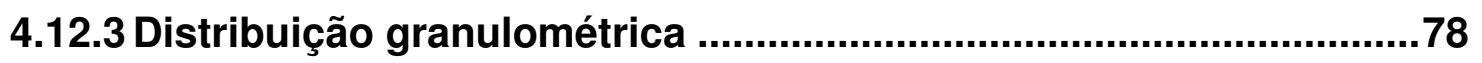

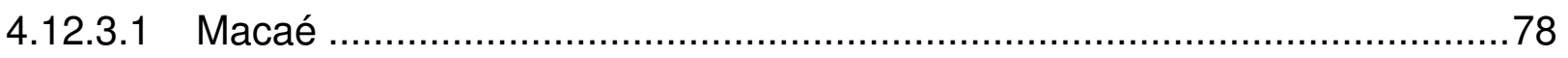

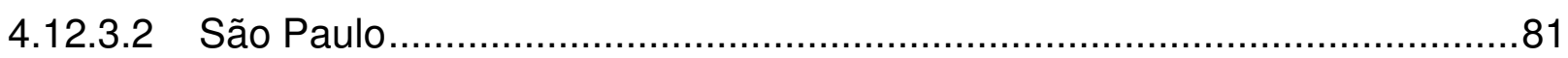

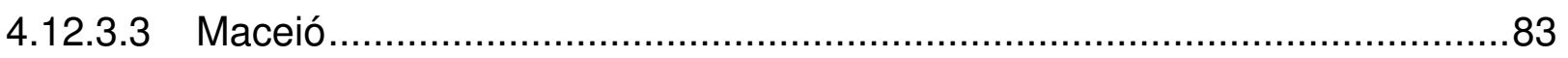

4.13 COMPARAÇÃO ENTRE AS CIDADES ………................................... 85

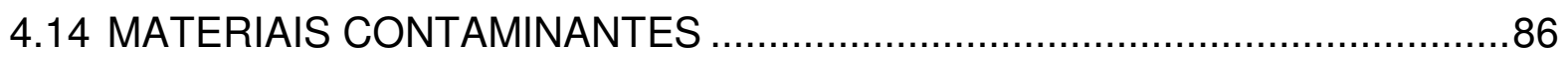

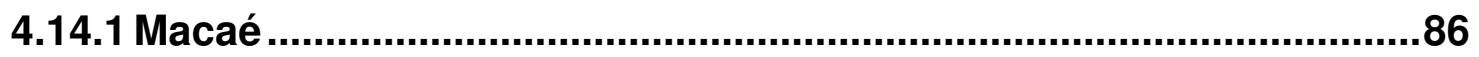

4.15 DISTRIBUIÇÃO DE DENSIDADE, MASSA ESPECÍFICA APARENTE,

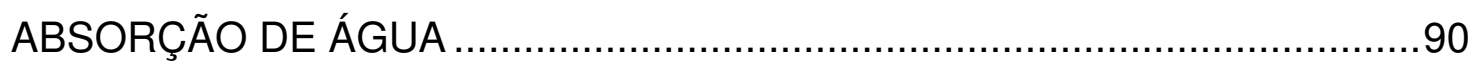

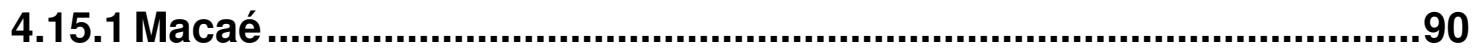

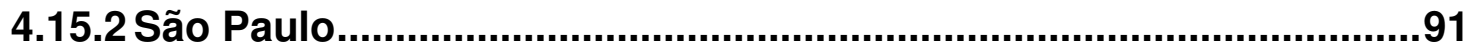

5. MODELO DINÂMICO PARA GERENCIAMENTO DO RCD NA CADEIA DA CONSTRUÇÃO CIVIL...................................................97

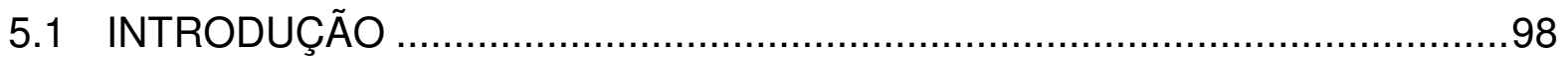

5.2 APLICAÇÕES DO SISTEMA DINÂMICO (SD) ……...............................100

5.3 MODELO 1: ANÁLISE CUSTO-BENEFÍCIO ...............................................103

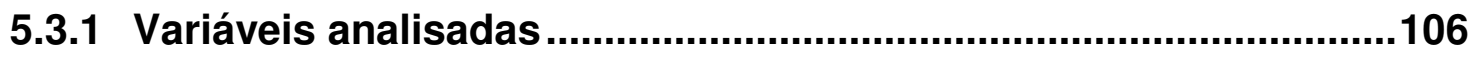

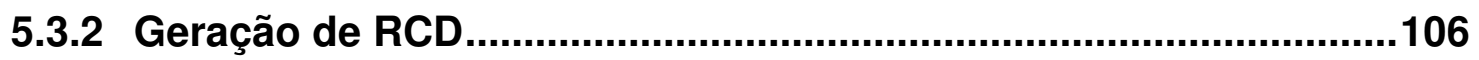

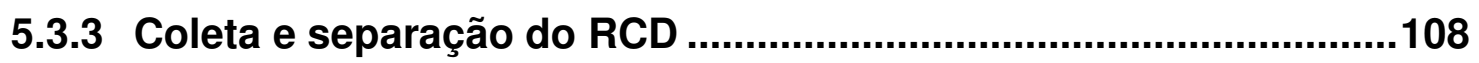

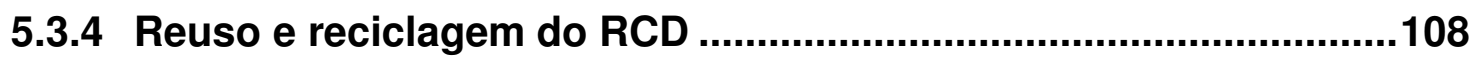

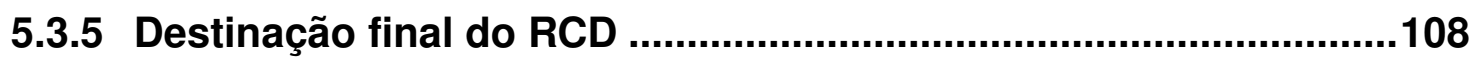

5.3.6 Os benefícios da reciclagem do RCD............................................111 
5.3.7 Análise de custo-benefício..............................................................111

5.3.8 Cenários considerados ….............................................................112

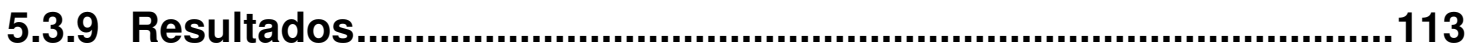

5.3.10 Comparativo entre as cidades analisadas......................................117

5.4 MODELO 2: VIABILIDADE A PARTIR DA QUALIDADE .............................122

5.4.1 Os circuitos em uma planta de reciclagem fixa ..............................123

5.4.2 As plantas móveis de reciclagem...................................................124

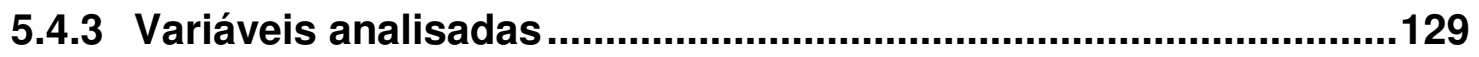

5.4.3.1 Variáveis de entrada na planta: ..........................................................129

5.4.3.2 Variáveis Operacionais e Financeiras ……...............................................130

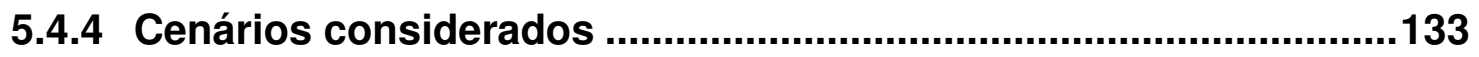

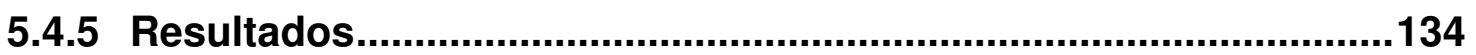

5.4.6 Propostas de solução da viabilidade da reciclagem em Macaé ...135

6. CONCLUSÕES E SUGESTÕES DE NOVOS ESTUDOS...................138

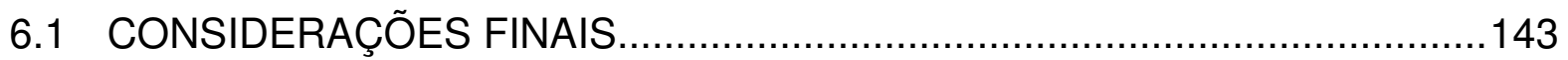

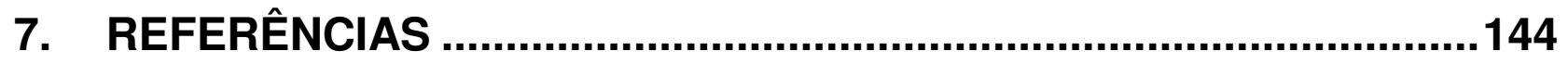

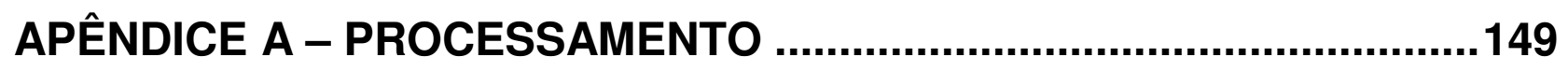

A.1 INFLUÊNCIA DOS DIFERENTES PROCEDIMENTOS DE CATAÇÃO NA DESCONTAMINAÇÃO DOS LOTES DE RCD ........................................150

A.2 INFLUÊNCIA DO TIPO DE BRITAGEM E DA ORIGEM NA QUALIDADE DO

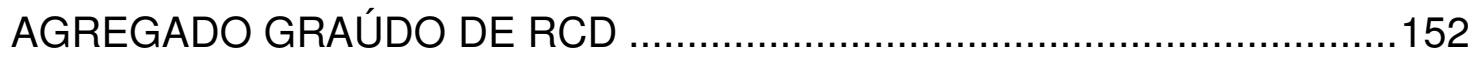

Britagem por impacto e por mandíbula ....................................................152

Definição dos circuitos fechados de britagem .........................................152

A.3 CARACTERIZAÇÃO DO AGREGADO GERADO PELO PROCESSAMENTO154 


\section{INTRODUÇÃO}

A indústria da construção civil é um dos mais importantes segmentos da economia e da sociedade. Na economia, se destaca por meio de capitais que mobiliza nas empresas construtoras, no emprego intensivo de mão de obra e na renda gerada como investimento de longo prazo. Já na sociedade, através da malha viária e das residências e escritórios onde os habitantes moram e trabalham.

Por sua vez, é intensiva em insumos não renováveis principalmente de origem mineral que respondem por $90 \%$ do volume total. Do ponto de vista da sustentabilidade, inclusive para marketing próprio, duas ações principais estão na agenda prioritária desta indústria. Uma linha, que não será ratada aqui, é quanto aos projetos amigáveis ao entorno e ao meio ambiente com materiais leves, duráveis. A segunda linha de ação relaciona-se com os Resíduos de Construção e Demolição (RCD), objeto desta tese.

No Brasil, foram geradas 70 milhões de t/ano de RCD em 2002 (ÂNGULO, S. et al., 2004) e um aumento da sustentabilidade da indústria requer a redução, reuso e a reciclagem (conhecido como os 3 R's) destes resíduos. A gestão do RCD, principalmente nos países em desenvolvimento, tem mais do que uma interface com os serviços públicos de coleta, descarte e, eventualmente, reciclagem. Na maioria dos municípios brasileiros há uma dependência do setor público nesta área, que tende a diminuir pela ação da indústria em paralelo à mudança da legislação nacional e aos procedimentos e normas municipais, o que resultam em taxas e subsídios a este nível.

A atuação da cadeia da construção civil pauta-se, além das considerações ambientais, por sofrer aumento dos preços dos agregados naturais associado à possibilidade de complementação da oferta dos mesmos por agregados reciclados. Isso acarreta redução de custos de transporte dos materiais e dos resíduos.

$\mathrm{Na}$ área pública, há pouco mais de uma década, em 2002, foi sancionada a resolução 307 do Conselho Nacional do Meio Ambiente (CONAMA) para gerenciamento dos resíduos da construção e demolição. 
Este marco regulatório definia o que eram estes resíduos, as classes, a triagem, o transporte, a reciclagem e o descarte. Além disso, criava o "Plano Integrado de Gerenciamento de Resíduos da Construção Civil”, elaborado pelos Municípios e pelo Distrito Federal. Criou-se um sistema tanto para os serviços públicos como para os grandes e pequenos geradores que era lógico, de fácil entendimento e aparentemente factível.

No entanto, somente a taxa de crescimento da construção civil se elevou na última década, em média, 8,5\% ao ano, como no ano 2000 a urbanização intensiva tinha sido, em grande medida, finalizada; o número de demolições, supõe-se, cresceu a taxas superiores (infelizmente não existem dados sobre demolições), elevando a taxa de geração de entulhos na década a mais de $10 \%$ ao ano. Levando em conta a geração média por habitante de 0,5 t/ano, teríamos 70 milhões (em 2002) de RCD gerado. A uma taxa de crescimento de $10 \%$ do entulho gerado, teríamos a cada ano um acréscimo de 7 milhões de toneladas no estoque de RCD.

Poucos municípios cumpriram parcialmente a norma. A esmagadora maioria dos municípios não cumpriu a Resolução Conama 307 de 2002. Por exemplo: Rio de Janeiro, a segunda maior cidade do país, permitiu o descarte dos resíduos de construção e demolição até o fechamento do Aterro Controlado do Jardim Gramacho em 2012. O Art. 13 vedava a disposição em aterros de resíduos domiciliares e Belo Horizonte, a capital mais avançada nesta área, alcançou a cifra máxima de $30 \%$ de tratamento dos resíduos gerados.

Este sistema dava mostra de fraqueza e esgotamento quando, em 2010, foi sancionada a lei 12305 que mudou o marco regulatório com princípios modernizantes como o do Poluidor Pagador e que instituiu a Política Nacional de Resíduos Sólidos (PNRS), possibilitando o uso de instrumentos econômicos para aumentar a sustentabilidade da cadeia da construção civil.

Em termos objetivos, a resolução Conama 307/2002 passou a fazer parte da história da Política Ambiental no Brasil. 


\subsection{OBJETIVOS DA PESQUISA}

O objetivo deste trabalho consiste em propor modelos dinâmicos para o gerenciamento dos resíduos da construção e demolição a nível municipal, visando aumentar a sustentabilidade da indústria mineral e da construção civil. A ferramenta utilizada foi o software l-think e os dados alimentados a partir de amostragens realizadas em três cidades brasileiras (São Paulo, Macaé, Maceió), bem como visitas a plantas de reciclagem no Brasil e no exterior.

Os modelos conceituais propostos são: o de Custo Benefício para as três cidades e o de Viabilidade para a cidade de Macaé.

O marco regulatório nacional define que cada município ajuste a gestão de resíduos sólidos às novas diretrizes. Estes modelos podem ser referência e contribuir para uma gestão do RCD mais eficiente e sustentável.

Outro objetivo consistiu em propor uma conceituação para a indústria recicladora emergente com a criação de um sub setor industrial distinto pertencente à cadeia da construção civil.

\subsection{A REVISÃO DA BIBLIOGRAFIA}

A preocupação com a viabilidade econômica e financeira nas atividades de reciclagem de $R C D$, incluindo o emprego dos agregados reciclados na construção civil, existia nos estudos acadêmicos, porém em número e profundidade muito menor que os trabalhos na área acadêmica com pesquisa experimental.

No entanto, pesquisadores da área experimental propunham trabalhos multidisciplinares para dar conta desta lacuna.

John, V. (2001) afirmou que a viabilidade financeira é algo fundamental em todas as etapas e deve ser avaliada em função do valor do mercado do produto, dos custos 
do processo de reciclagem e do custo de disposição em aterro. Segundo ele, uma metodologia específica precisava ser desenvolvida.

O potencial de mercados para emprego de agregados reciclados foi considerado promissor segundo Ângulo, S. (2002). O autor chegou à conclusão de que existia um mercado para o uso em pavimentação, mas levando em conta o enorme volume de RCD gerado, dever-se-ia dar ênfase aos reciclados de concreto, que remuneram melhor o reciclador. Para que este fato ocorresse, seria necessário utilizar práticas, oriundas da indústria mineral, como triagem e separação dos resíduos mais eficientes.

Uma abordagem um pouco diferente, mas com o mesmo propósito, isto é, selecionando cidades brasileiras com maior potencial para a viabilidade da reciclagem encontra-se em Planejamento de Programas de Reciclagem de Resíduos da Construção e Demolição no Brasil: uma análise multivariada (COSTA, N. et al, 2007).

No entanto, estudos completos sobre viabilidade econômica e financeira de empresas recicladoras e com as ferramentas da matemática financeira para avaliação de investimentos para Projetos Industriais, existem dois trabalhos a serem considerados:

Jadovski (2005) em seu trabalho utilizou os modelos de avaliação de investimento corretos, mas como tais modelos eram para diretrizes na área de reciclagem, havia nele hipóteses muito otimistas como, por exemplo, supunha diferenciais de preços para o agregado reciclado de concreto em relação ao agregado natural, baseado em mercados consolidados e principalmente não se apoiou em medição dos custos e receitas das empresas. A meu ver, o mercado de reciclados, naquele período, estava em formação, isto é, era uma "quase-mercadoria" que não tinha preço definido no tempo, oscilava muito com o momento das transações. O autor registrava a viabilidade positiva para empresa pública e privada em plantas a partir da produção de 30 t/h e 40 t/h, respectivamente.

Em pesquisa realizada em 2003, por Nunes et al. (2007) foram processados os dados obtidos através de questionários, entrevistas e em alguns casos acesso a dados econômico-financeiros das recicladoras. Embora tenha assumido um 
referencial de preços entre agregados naturais e reciclados semelhante ao trabalho anterior as informações de custos das recicladoras são muito detalhadas e foram obtidos em exaustivo trabalho de campo. Mesmo sendo benevolente em relação aos preços; os números obtidos eram mais próximos da realidade. A autora citou "a nãoviabilidade das empresas da iniciativa privada para implantação e operação de reciclagem de RCD (Resíduos de Construção e Demolição), nas atuais condições de mercado", e concluiu que as Centrais de Reciclagem públicas existiam devido à tomada de decisão de levar em conta também a contabilidade social e ambiental, não só a econômico-financeira na área.

Estas duas teses anteriores usavam modelos estáticos para avaliar os investimentos, desempenho e a viabilidade das centrais de reciclagem existentes naquele período.

\subsection{PROPOSTA INOVADORA E ESTRUTURA DA TESE}

A abordagem do resíduo da construção como mercadoria, que forma um mercado de reciclados e uma indústria recicladora emergente, que possibilita uma modelagem dinâmica a nível municipal, é pioneira na literatura desta área no Brasil. Este trabalho contém os seguintes capítulos:

No capítulo II: para planejar o futuro da gestão dos RCD temos que entender a experiência da década passada e utilizar a noção de criação do valor econômico do resíduo como insumo para os agregados reciclados, concomitante a um processo formativo do mercado de reciclados e da indústria recicladora emergente, em um processo que denominamos "A Formação da Mineração Urbana no Brasil".

A formação deste mercado dentro do marco regulatório da Resolução CONAMA 307 de 2002 é que permite a constituição da indústria de reciclagem emergente através de uma série de empresas com capacidade de produzir agregados reciclados com qualidade, possibilitando ganhos de escala de mercado bem além daqueles utilizados na pavimentação. 
No capítulo III - "A indústria recicladora emergente e a madura" propomos uma reflexão entre uma trajetória industrial consolidada, isto é, madura, na qual se formou um mercado de reciclados com propriedades semelhantes aos naturais, sendo certificados pelos órgãos reguladores e a trajetória da indústria nascente. A proposta é investigar o que é necessário realizar para chegar-se a este nível de produtos.

No capítulo IV - O trabalho experimental - foi realizada uma amostragem dos RCD inovadora pela sua metodologia e extensão, principalmente na cidade de Macaé, considerando o RCD histórico (depositado nos aterros) e o presente (gerado no período de amostragem). Além disto, realizamos amostragens considerando o entulho presente gerado em uma região da cidade de São Paulo e na cidade de Maceió. Os dados obtidos permitiram a modelagem dinâmica.

No capítulo V - os estudos publicados na área de gestão (viabilidade econômica financeira) de RCD no Brasil utilizavam modelos estáticos que não davam mais conta da realidade e da complexidade que o tema revestiu-se. Aumentaram o número dos agentes econômicos e regulatórios alem das várias atividades e destinações possíveis na gestão do RCD, a nível municipal. Tornou-se indispensável para a tomada de decisões, na esfera municipal, a modelagem dinâmica.

Na literatura em geral deste assunto, existem vários modelos dinâmicos a nível do município ou regional que será comentado no Capítulo $V$, em que os dados alimentados dos resíduos (método direto ou indireto de coleta) são da indústria da construção civil (construção, renovação e demolições) por meio de amostragem dos contratos e entrevistas ou balanços de massa, mas o diferencial na nossa pesquisa é que os dados que foram apresentados no tocante ao conteúdo dos resíduos foram obtidos por amostragem como se a coleta ocorresse no momento do descarte, isto é, aumentando o viés metodológico do estudo com técnicas da indústria mineral.

No capítulo VI apresenta-se a conclusão geral, destacando as conclusões dos modelos dinâmicos que dão sentido à "Formação da Mineração Urbana no Brasil”. 
2. GESTÃo DE RESÍDUOS SÓLIDOS E A MINERAÇÃO URBANA

"As coisas estão no mundo, só que eu preciso aprender".

Letra de Paulinho da Viola em As coisas do mundo, minha nega. 


\subsection{INTRODUÇÃO}

A urbanização no Brasil realizou-se principalmente após os anos 60 com o grande fluxo migratório do campo para a cidade. Cerca de $40 \%$ da população estava no campo em 1950 e nos dias de hoje inverteram-se estas posições com mais de 86\% da população vivendo nas cidades. O aumento da população deveu-se à industrialização e melhoria dos serviços como saúde, transporte e comunicação nos núcleos urbanos.

Devido a este crescimento das cidades, os serviços como esgotamento sanitário, coleta e tratamento de resíduos sólidos formaram uma área de política pública e também acadêmica que se denomina saneamento básico. Esta área compreende quatro esferas de atividades e competências, a saber:

1) abastecimento de água;

2) coleta e tratamento dos esgotos sanitários;

3) gerenciamento dos resíduos sólidos urbanos;

4) drenagem urbana.

No tocante ao abastecimento de água, os índices da Pesquisa Nacional de Saneamento Básico (PNSB), de 2008, mostram a universalização (99,4\%) destes serviços nos municípios brasileiros. Entretanto, durante a coleta e destinação de efluentes líquidos temos uma situação diversa, somente 55,2\% dos municípios (pouco mais da metade) têm esgotamento sanitário compreendendo a coleta e não necessariamente o tratamento destes efluentes.

Igualmente universal é a coleta dos resíduos sólidos urbanos. No tocante aos RCD temos $71 \%$ dos municípios com serviço de coleta destes resíduos. Porém, em 1.579 municípios brasileiros ${ }^{1}$ os RCD são depositados em lixões ${ }^{2}$. Os problemas principais do saneamento básico estão na coleta e no tratamento dos esgotos sanitários efluentes e na disposição final em locais totalmente inadequados dos RSU's, como os lixões.

\footnotetext{
${ }^{1}$ Dados da ABRELPE mostrando a grande precariedade do sistema

${ }^{2}$ A lei 12350/2010 prevê a extinção dos lixões em 2014
} 


\begin{tabular}{|c|c|c|c|c|c|c|c|c|c|c|}
\hline \multirow[b]{4}{*}{$\begin{array}{c}\text { Grupos de tamanho dos municípios } \\
\text { e densidade populacional }\end{array}$} & \multicolumn{10}{|c|}{ Municípios } \\
\hline & \multirow[b]{3}{*}{ Total } & \multicolumn{9}{|c|}{ Com serviço de manejo de resíduos sólidos } \\
\hline & & \multirow[b]{2}{*}{ Total } & \multicolumn{8}{|c|}{ Natureza dos serviços } \\
\hline & & & $\begin{array}{c}\text { Coleta } \\
\text { domiciliar } \\
\text { regular de } \\
\text { lixo }\end{array}$ & \begin{tabular}{|c|} 
Varrição \\
de ruas \\
públicas
\end{tabular} & 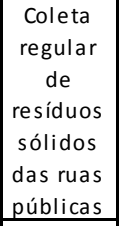 & $\begin{array}{c}\text { Coleta } \\
\text { seletiva } \\
\text { de } \\
\text { resíduos } \\
\text { sólidos } \\
\text { recicláveis }\end{array}$ & $\begin{array}{l}\text { Triagem } \\
\text { de } \\
\text { resíduos } \\
\text { sólidos } \\
\text { recicláveis }\end{array}$ & $\begin{array}{l}\text { Coleta } \\
\text { de RCD }\end{array}$ & \begin{tabular}{|c|} 
Coleta de \\
resíduos \\
sólidos \\
especiais: \\
de saúde e \\
industriais
\end{tabular} & \begin{tabular}{|c|} 
capina \\
de ruas \\
públicas
\end{tabular} \\
\hline Total & 5564 & 5562 & 5540 & 5403 & 5446 & 994 & 990 & 3985 & 4464 & 5404 \\
\hline $\begin{array}{l}\text { Até } 50000 \text { habitantes e densidade } \\
\text { menor que } 80 \text { hab. } / \mathrm{km} 2\end{array}$ & 4511 & 4509 & 4490 & 4382 & 4424 & 633 & 684 & 3338 & 3560 & 4403 \\
\hline $\begin{array}{l}\text { Até } 50000 \text { habitantes e densidade } \\
\text { maior que } 80 \text { hab./km2 }\end{array}$ & 487 & 487 & 485 & 475 & 468 & 103 & 96 & 328 & 398 & 474 \\
\hline $\begin{array}{l}\text { De } 50000 \text { a } 100000 \text { habitantes e } \\
\text { densidade menor que } 80 \text { hab./km2 }\end{array}$ & 148 & 148 & 148 & 146 & 147 & 39 & 32 & 101 & 130 & 142 \\
\hline $\begin{array}{l}\text { De } 50000 \text { a } 100000 \text { habitantes e } \\
\text { densidade maior que } 80 \text { hab./km2 }\end{array}$ & 165 & 165 & 164 & 158 & 159 & 76 & 60 & 77 & 140 & 153 \\
\hline $\begin{array}{l}\text { De } 100000 \text { a } 300000 \text { habitantes e } \\
\text { densidade menor que } 80 \text { hab./km2 }\end{array}$ & 39 & 39 & 39 & 39 & 38 & 13 & 9 & 20 & 36 & 37 \\
\hline $\begin{array}{l}\text { De } 100000 \text { a } 300000 \text { habitantes e } \\
\text { densidade maior que } 80 \text { hab./km2 }\end{array}$ & 135 & 135 & 135 & 125 & 132 & 75 & 62 & 69 & 130 & 121 \\
\hline De 300000 a 500000 habitantes & 43 & 43 & 43 & 42 & 43 & 26 & 21 & 21 & 39 & 41 \\
\hline De 500000 a 1000000 habitantes & 22 & 22 & 22 & 22 & 21 & 16 & 14 & 19 & 19 & 20 \\
\hline Mais de 1000000 habitantes & 14 & 14 & 14 & 14 & 14 & 13 & 12 & 12 & 12 & 13 \\
\hline
\end{tabular}

Figura 2.1 - Municípios, total e com serviço de manejo de resíduos sólidos, por natureza dos serviços, segundo os grupos de tamanho dos municípios e a densidade populacional de 2008.

Fonte: Pesquisa do Saneamento Básico de 2008

A gestão do RCD é realizada por meio dos procedimentos e atividades obedecendo à logística da gestão dos resíduos sólidos no âmbito municipal e em grande parte vinculada aos resíduos domiciliares. A coleta e o transporte são obrigações dos grandes geradores; no caso dos pequenos geradores a competência é da empresa municipal ou terceirizada. A destinação ao local de descarte e da gestão deste sistema é, na maioria das vezes, de responsabilidade da Prefeitura.

Pode-se afirmar que ocorreu uma evolução positiva no país no tocante a esta questão. Houve uma universalização da coleta de resíduos sólidos neste período, como mostra a comparação dos dados do censo de 2000 com os dados provenientes da Pesquisa do Saneamento Básico de 2008.

Em 2000 não foram coletados dados de resíduos de construção e demolição, mas em 2008 constata-se um número expressivo de municípios (72\%) com serviço de manejo de resíduos de construção e demolição; cerca de 4.000 em um universo de 5564 municípios. No entanto, somente cerca de 390 apresentam algum tipo de 
processamento dos resíduos de construção e demolição, cerca de 10\% destes municípios. Deste total tem-se 124 que possuem triagem simples dos resíduos de construção e demolição reaproveitáveis (classe A e B), sendo 14 com classificação granulométrica e $20 \mathrm{com}$ triagem de resíduos de classe A. Somente em 1979 há o reaproveitamento dos agregados produzidos na fabricação de componentes construtivos. Embora não existam dados sobre a produção destas plantas de reciclagem ou qualquer balanço de massa, observamos que estas plantas concentram-se nos municípios de população maior do que 50 mil habitantes.

No tocante à disposição, os dados mostram que cerca de 1.330 municípios, ou seja, $33 \%$ destes colocam o RCD em vazadouro ou lixões em conjunto com os demais resíduos; 442 dispõem controladamente em aterro convencional em conjunto com os demais resíduos; 176 dispõem em pátio ou galpão específico para resíduos especiais; 448 dispõem sob controle em aterros específico para resíduos especiais e 795 têm utilização definitiva e controle dos resíduos como material de aterro após triagem e remoção dos resíduos classe B, C, D. Somando estes municípios que estão pelo menos dispondo separadamente os resíduos, encontramos 1.419, um número bastante expressivo, formando uma massa considerável de RCD que pode ser tratada e recuperada (PNSB, 2008).

Quanto ao descarte clandestino, não temos dados concretos sobre este fenômeno encontrado em todas as cidades brasileiras, mas sem dúvida é alto.

Tabela 2.1 - Município com ou sem acesso a serviços de limpeza e/ou coleta de lixo.

\begin{tabular}{cccc}
\hline $\begin{array}{r}\text { Município com ou sem acesso a serviços de } \\
\text { limpeza e/ou coleta de lixo }\end{array}$ & $\begin{array}{c}\text { Número de } \\
\text { municípios } \\
\text { brasileiros }\end{array}$ & $\begin{array}{c}\text { \% em relação ao número } \\
\text { total de municípios } \\
\text { brasileiros }\end{array}$ \\
\hline Sem serviços de limpeza e/ou coleta de lixo & 2 & $0,04 \%$ \\
\cline { 2 - 4 } & Coleta nas vias públicas & 5446 & $97,88 \%$ \\
\cline { 2 - 4 } $\begin{array}{c}\text { Com serviços de } \\
\text { limpeza e/ou } \\
\text { coleta de lixo }\end{array}$ & Coleta seletiva & 5540 & $99,57 \%$ \\
\cline { 2 - 4 } & Remoção de entulho & 994 & $17,86 \%$ \\
\cline { 2 - 4 } & Coleta de lixo especial & 4990 & $17,79 \%$ \\
\cline { 2 - 4 } & Total & 5562 & $71,62 \%$ \\
\hline
\end{tabular}

Fonte: IBGE/PNSB (2008) 
Tabela 2.2 - Municípios com e sem serviço de manejo de RCD e o tipo de processamento dos resíduos.

\begin{tabular}{|c|c|c|c|}
\hline \multicolumn{3}{|c|}{ Existência e tipo de processamento do RCD } & $\begin{array}{l}\text { Quantidade de } \\
\text { municípios }\end{array}$ \\
\hline \multicolumn{3}{|c|}{ Sem serviço de manejo de RCD } & 1533 \\
\hline \multirow{8}{*}{$\begin{array}{l}\text { Com serviço } \\
\text { de manejo de } \\
\text { RCD }\end{array}$} & & n processamento do RCD & 3639 \\
\hline & \multirow{6}{*}{$\begin{array}{c}\text { Com } \\
\text { processamento } \\
\text { do RCD }\end{array}$} & Triagem simples (classe $\mathrm{A}$ e $\mathrm{B}$ ) & 124 \\
\hline & & Triagem e trituração simples do classe $\mathrm{A}$ & 14 \\
\hline & & $\begin{array}{l}\text { Triagem e trituração simples do classe A, } \\
\text { com classificação granulométrica }\end{array}$ & 20 \\
\hline & & Com reaproveitamento & 79 \\
\hline & & Outros & 204 \\
\hline & & Total & 392 \\
\hline & & Total & 4031 \\
\hline
\end{tabular}

Fonte: IBGE/ PNSB (2008)

Tabela 2.3 - Forma de disposição do RCD.

\begin{tabular}{ccc}
\hline Formas de disposição do RCD no solo & Munic. & $(\%)$ \\
\hline Em vazadouro, com outros resíduos & 1330 & $32,99 \%$ \\
\hline Em aterros controlados, misturados & 442 & $10,97 \%$ \\
\hline Pátios de estocagem específicas & 176 & $4,37 \%$ \\
\hline Em aterros controlados, separados & 267 & $6,62 \%$ \\
\hline Em aterros de terceiros específicos & 181 & $4,49 \%$ \\
\hline Utilização pela prefeitura, após triagem & 503 & $12,48 \%$ \\
\hline Utilização por terceiros, após triagem & 292 & $7,24 \%$ \\
\hline Outros & 1235 & $30,64 \%$
\end{tabular}

Fonte: IBGE/ PNSB (2008)

A PNSB 2008 é a primeira pesquisa com dados de abrangência nacional que mostra que a resolução CONAMA 307/02, a qual dispõe sobre descarte e reciclagem de $R C D$, foi importante no sentido da conscientização de que a gestão dos RCD deveria superar a simples coleta do resíduo. Esta resolução levou a criação de uma infraestrutura de aterros de transporte mesmo que imperfeita e lançou as bases do reuso e reciclagem dos $\mathrm{RCD}$.

\subsection{O MERCADO DE RCD EM FORMAÇÃO}

Os resíduos da construção e demolição têm sua origem nas atividades da construção civil. Segundo John; Agopyan (2001), os resíduos provêm de uma ampla variedade de produtos e podem ser classificados em: 
a) solos;

b) materiais cerâmicos: rochas naturais, concreto, argamassas e base de cimento e cal; resíduos de cerâmica vermelha como tijolos e telhas; cerâmica branca, especialmente a de revestimento; cimento-amianto; gesso-pasta e placa, vidro;

c) materiais metálicos: como aço para concreto armado, latão, chapas de aço galvanizado, etc;

d) materiais orgânicos: como madeira natural ou industrializada; plásticos diversos; materiais betuminosos; tintas e adesivos; papel de embalagem; restos de vegetais e outros produtos de limpeza de terrenos.

Fazendo a leitura da Resolução 307/2002 como um marco que seleciona e estimula a valorização de resíduos como oferta complementar no mercado da construção civil, foram elegíveis "os de classe A": resíduos reutilizáveis ou recicláveis como agregados, tais como: a) de construção, demolição, reformas e reparos de pavimentação e de outras obras de infraestrutura, inclusive solos provenientes de terraplanagem; b) de construção, demolição, reformas e reparos de edificações: componentes cerâmicos (tijolos, blocos, telhas, placas de revestimento etc.) argamassa e concreto; c) de processo de fabricação e/ou demolição de peças prémoldadas em concretos (blocos, tubos, meio fios) produzidas nos canteiros de obra e "os de classe B": os resíduos recicláveis para outras destinações, tais como: plásticos, papel/papelão, metais, vidros, madeiras e outros.

A partir dos anos 90, iniciam-se uma série de estudos sistemáticos sobre RCD no Brasil em centros Universitários como na USP, Ribeirão Preto e UFBA.

A urbanização acelerada com a reestruturação de áreas causadas pelo adensamento, bem como o crescimento das cidades de médio e pequeno porte e a formação das regiões metropolitanas suscitaram questões ligadas à gestão dos resíduos sólidos, os problemas gerados e como solucioná-los. Uma das teses mais representativas é de Pinto,T. (1999), da Engenharia Civil da USP, intitulada "Metodologia para a Gestão Diferenciada de Resíduos Sólidos da Construção Urbana" cuja ênfase é na gestão diferenciada do resíduo, constituída por um conjunto de ações que corporificam um novo serviço público com captação máxima dos resíduos gerados, sua reciclagem, bem como alteração de procedimentos e de culturas (p.108). Em 2002, a cidade de Belo Horizonte já era um ícone de grande 
cidade com duas plantas de reciclagem, 22 pontos de coleta de resíduos espalhados na malha urbana, cooperativa de catadores organizada, programas com o SEBRAE, em suma, uma vitrine que permanece até hoje embora processe somente cerca de $30 \%$ do total do entulho produzido.

Este modelo se contrapunha à Gestão Corretiva que se caracterizava por englobar atividades não preventivas, repetitivas e custosas das quais não surtiam resultados adequados. A Gestão Corretiva sustenta-se na "inevitabilidade" de áreas com deposição irregular, degradando o ambiente urbano, e as proximidades das regiões fortemente geradoras de RCD enquanto houver a disponibilidade de áreas de aterramento. Sem tirar o mérito do trabalho, porque a ênfase é na gestão diferenciada, o autor aponta para valores na ordem de $R \$ 5,00$ (p. 96) por tonelada de RCD processada, ressalvando que a questão tornava-se muito complexa no tocante à determinação do custo porque eram autarquias controladas pelo poder público. Nunes, K.R.A 2004 tinha como foco a viabilidade das plantas de reciclagem, efetuando estudo completo dos custos: os valores encontrados são bem superiores para $\mathrm{BH}$, na ordem de 10,00 R\$/t, Ribeirão Preto 28,40 R\$/t, São Paulo 23,50 R\$/t. Independente dos valores encontrados nestes estudos pioneiros, há uma clara preocupação em atribuir um valor ao RCD.

Mesmo antes da resolução, alguns serviços públicos municipais já tinham planos de gestão de RCD, inclusive com triagem e reciclagem como Belo Horizonte, ao passo que outros municípios tinham "mera aquisição de equipamentos descoordenada de um planejamento de ações, o que inevitavelmente compromete os resultados a serem alcançados" (Pinto, T., 1999).

A resolução suscitou uma série de ações indutivas a práticas sustentáveis nos vários níveis de governo e na sociedade. No âmbito federal: o financiamento dos equipamentos de britagem e moagem e o financiamento a fundo perdido de valores para terrenos destinados ao transbordo e à reciclagem de RCD. No nível estadual, parte dos fundos para o meio ambiente, cujos valores eram originados das multas e compensações financeiras pagas pelas empresas aos Estados, foi dirigida ao financiamento de aterros públicos municipais ou regionais para atender vários municípios. 
Neste período, informalmente, pedreiras já em fase de esgotamento da brita ou devido ao crescimento urbano que impedia explosões, processaram de forma descontínua resíduos nos equipamentos de britagem/peneiramento, por encomenda de construtoras ou de Prefeituras, conforme a Figura 2.2.

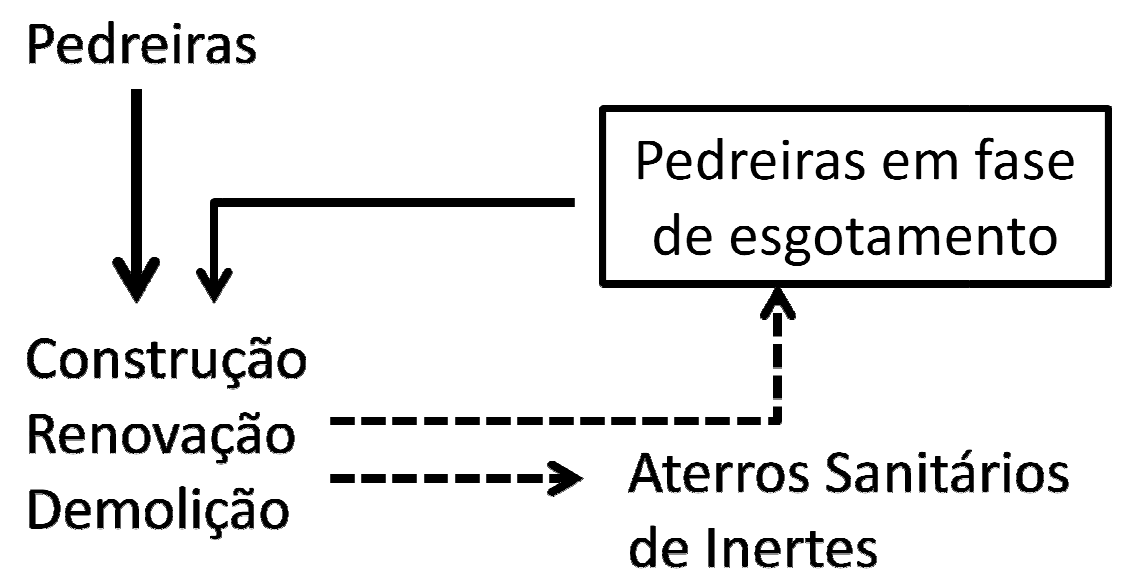

Figura 2.2 - Processamento de resíduos por parte das pedreiras.

Por sua vez, sintetizando a análise dos dados da PNSB (IBGE,2008) observa-se que 390 municípios realizavam processamento dos resíduos de construção, sendo que em 79 havia o reaproveitamento dos agregados produzidos na fabricação de componentes construtivos, em 2008.

Em números absolutos, 390 municípios com processamento de RCD e o conjunto dos dados circunstanciados acima nos permite concluir que existia um mercado secundário em formação para reuso e reciclagem dos RCD.

Por isso, adotou-se o conceito de Mineração Urbana que, em uma versão mais ampla, a Waste Management 32 (2012, p.1737) define: "A mineração urbana comporta as ações e as tecnologias utilizadas para a recuperação dos recursos provenientes dos resíduos produzidos pelo catabolismo urbano (resíduos municipais, industriais ou agrícolas, seja da produção recente como de antigos depósitos) em termos de matéria-prima secundária e energia". Neste estudo há uma definição mais restrita vinculada aos resíduos gerados na cadeia da construção civil e principalmente ao estoque mineral, à disposição das empresas recicladoras de $\mathrm{RCD}$, que, por analogia, são as mineradoras urbanas. 
A formação da mineração urbana no Brasil diz respeito à mudança do tratamento do RCD da esfera do saneamento básico para o âmbito do resíduo como matéria-prima secundária para agregados. Neste sentido, houve uma acumulação de condições de mercado como formação de estoques inicialmente públicos, estações de transbordo, práticas e uso destes resíduos na pavimentação. Por outro lado em movimento auxiliar se editam normas da ABNT que normatizam o emprego dos resíduos na construção civil, como agregados reciclados.

No Brasil, os municípios são os responsáveis pela gestão do RCD dos pequenos geradores. Em geral, os grandes geradores realizam o transporte e o aterro sanitário ou lixão é gerido por uma empresa ou autarquia municipal. A coleta seletiva de RCD não é adotada. A demolição seletiva é realizada em situações específicas, como a demolição de um prédio histórico ou de grande valor arquitetônico devido aos elevados custos envolvidos. Poucos municípios adotam a licença de demolição como registro legal desta atividade. Já em alguns estados há fiscalização da movimentação do RCD através de guia de transporte de resíduos emitidos pelo órgão ambiental estadual.

A partir de uma perspectiva histórica, constata-se que as empresas recicladoras públicas ou concessionárias de RCD têm relação com a área do saneamento ambiental. No Brasil esta relação é dominante; as usinas de reciclagem na sua maioria pertenciam às empresas municipais ou eram privadas e operavam em regime de concessão. Inclusive, vários municípios outorgavam conjuntamente a coleta dos lixos e do RCD.

Esse cenário mudou nos últimos anos: estão se multiplicando as empresas privadas de reciclagem de RCD no país, principalmente no Centro-Sul. Estas empresas são essencialmente vinculadas ou mesmo originárias da cadeia da Construção Civil. Estão formando-se entidades associativas destas empresas, como a Associação Brasileira para Reciclagem dos Resíduos da Construção Civil e Demolição, fundada em fevereiro de 2011 e que registra cerca de 117 plantas de reciclagem em operação. Além destes números, o ambiente de negócios no mercado dos agregados reciclados está favorável às estas empresas, ofertando produtos mais 
homogêneos e valiosos como a areia e a brita reciclada ${ }^{3}$, além da tradicional bica corrida $^{4}$ e do rachão ${ }^{5}$.

\subsection{LEGISLAÇÃO E CICLO DO PRODUTO}

\subsubsection{A mudança do marco regulatório na área ambiental}

$\mathrm{Na}$ Política Ambiental das sociedades modernas houve uma mudança do termo "Governo" para caracterizar as decisões oriundas somente dos vários níveis de Poder(federal,estadual , municipal) para " Governança” onde considera-se alem do Governo, outros atores da sociedade civil como ONGs, grupos de pressão, setor privado para à tomada de decisões na área ambiental. Esta mudança deve-se a complexidade dos diversos interesses em jogo nas comunidades urbanas que são administrados por pressão e contra pressão destes atores nas varias instâncias de governo. Ver (Marshall,R.;Farahbakhsh,K. 2013.)

Na construção civil são gerados "custos ambientais" que são levados em conta na Governança para a gestão dos resíduos sólidos das cidades.

Os custos ambientais gerados na produção dos agregados naturais começam no momento da extração dos agregados (recursos não renováveis) com prejuízo ao meio ambiente. A população circunvizinha às pedreiras e aos areais são afetadas pelo ruído e pelos particulados dispersos no ambiente. Além disso, o descarte

\footnotetext{
${ }^{3}$ Brita reciclada: Material com dimensão máxima característica inferior a $39 \mathrm{~mm}$, isento de impurezas, proveniente da reciclagem de concretos e blocos de concretos da construção civil. Seu uso é recomendado para fabricação de concretos não estruturais e drenagens. (Disponível em <http://www.urbem.com.br/principal.htm>. Acesso em: 18 abr. 2013).
}

\footnotetext{
${ }^{4}$ Bica corrida: Material proveniente da reciclagem de resíduos da construção civil, livre de impurezas, com dimensão máxima característica de $63 \mathrm{~mm}$. Seu uso é recomendado para obras de base, subbase, reforço do subleito e subleito de pavimentos, além de regularização de vias não pavimentadas, aterros e acerto topográfico de terrenos. (Disponível em <http://www.urbem.com.br/principal.htm>. Acesso em: 18 abr. 2013).

${ }^{5}$ Rachão: Material com dimensão máxima característica inferior a $150 \mathrm{~mm}$, isento de impurezas, proveniente da reciclagem de concretos e blocos de concretos da construção civil. Seu uso é recomendado para obras de pavimentação, drenagens, terraplenagem, etc. (Disponível em <http://www.urbem.com.br/principal.htm>. Acesso em: 18 abr. 2013).
} 
irregular dos resíduos origina áreas degradadas e possíveis criadouros de vetores de doenças como a dengue. Os terrenos próximos a qualquer lugar de descarte é desvalorizado. Mesmo aqueles RCD descartados em aterros apropriados, os quais ocupam espaço desnecessário, poderiam ser reusados e reciclados.

O paradigma em que a governança ambiental atuava era conhecido como COMANDO e CONTROLE. Isto é, a governança estabelecia leis, normas, procedimentos e estabelecia mecanismo de controle através dos organismos de fiscalização em cada nível da governança. Um exemplo é a conhecida resolução CONAMA 307/2002, que foi o marco regulatório nacional até recentemente, contendo diretrizes para gestão dos resíduos que ocorriam nos municípios e que se adaptavam ou não a estas diretrizes, mas procuravam de acordo com fatores locais gerir estes resíduos e controlavam principalmente a disposição irregular dos mesmos.

Por sua vez, o desenvolvimento econômico e a urbanização amplificaram os problemas relatados acima, mas ao mesmo tempo criaram possíveis soluções em adotar mecanismos econômicos para solucionar estes problemas, como no caso, fomentando o mercado de reciclados. Esta solução vem ao encontro aos construtores porque os mesmos fatores citados provocaram um aumento dos preços dos agregados naturais.

Exemplo é a lei 12.305 de 2010 que institui a Política Nacional de Resíduos Sólidos que tem dentre os seus Princípios no Art. 6을

I) O poluidor-pagador e o protetor-recebedor;

II) Responsabilidade compartilhada pelo Ciclo de Vida do produto.

Dentre seus Objetivos no Art. 7은

I) Os serviços públicos de limpeza urbana e de manejo de resíduos sólidos com adoção de mecanismos gerenciais e econômicos que assegurem a recuperação dos custos dos serviços prestados, como forma de garantir sua sustentabilidade operacional e financeira, observada a Lei no 11.445 de 2007.

A nova lei coloca o agente poluidor para ressarcir a sociedade sobre a emissão de poluentes e a responsabilidade do gerador dos resíduos desde o início até a 
disposição final do produto, bem como incentiva a criação de mecanismos de mercado no gerenciamento dos resíduos sólidos.

No caso de RCD, a cadeia da construção civil terá a responsabilidade compartilhada de arcar com os custos do gerenciamento dos resíduos, exceto para os grandes geradores.

Existe uma explícita mudança do marco regulatório do sistema ambiental de "COMANDO E CONTROLE" vigente até então para o paradigma "POLUIDORPAGADOR" a partir dos desdobramentos desta lei.

Em cada município, estão ocorrendo formas de adaptação às novas leis através de taxas, subsídios, incentivos, permutas, obrigatoriedade de uso do RCD nas obras licitadas pela Prefeitura, isto é, instrumentos econômicos no gerenciamento dos resíduos e incentivando o fortalecimento de um mercado de agregados reciclados.

Em grande parte dos municípios brasileiros, até o momento, onde existe o gerenciamento dos resíduos, o RCD é pago totalmente ou em parte com fundos oriundos do contribuinte de maneira genérica.

É usual o proprietário de imóveis, através de uma alíquota do IPTU conhecida como "taxa do lixo", arcar com estes custos de gerenciamento. A lei veta o descarte de RCD conjuntamente com os RSU's.

Em municípios como o Rio de Janeiro, a Companhia de Limpeza (COMLURB) recolhia gratuitamente o RCD tanto do pequeno gerador como do grande gerador para depositar no aterro público de Gramacho que foi fechado em 2012. A solução foi licitar áreas públicas para instalação de empresas recicladoras, isto é, subsídio na forma de comodato do terreno.

Por outro lado, criaram-se, nos últimos anos, conjunturas econômicas em regiões altamente industrializadas onde ocorreram reduções da oferta de agregados naturais com preços aumentados devido ao aumento dos custos de transporte, e as restrições ambientais à sua exploração causando escassez da brita e areia. Houve um aumento dos RCD disponíveis com elevado conteúdo de concreto oriundo das construções e demolições em zonas industriais ou pós-industriais como o da cidade 
de SP, em região com infraestrutura inativa devido à descentralização industrial para o interior.

Na região do entorno de Campinas (SP), onde empresas privadas como a SOLOS, pertencente à cadeia da construção civil, estabeleceram-se, de início com acordo informal com as prefeituras de Americana e Nova Odessa, mas cresceram, diversificaram seus produtos e firmaram-se em um mercado do agregado reciclado estável. Nestas cidades, cerca de $80 \%$ do entulho gerado é reutilizado e reciclado (Pinto, T., 2011).

Outro aspecto da lei de resíduos sólidos foi alterar a lei 9.065, de 12 de fevereiro de 1998, porque revogou a responsabilidade exclusiva dos municípios sobre a gestão dos resíduos sólidos, instituindo a responsabilidade compartilhada dos geradores durante o ciclo de vida do produto.

A lei 12.305/2010 é uma tendência modernizadora e tramitou durante dezessete anos no Congresso, evidenciando as dificuldades e impasses das leis ambientais que responsabilizam monetariamente os geradores.

Nos países da Europa, EUA e Japão, os custos da gestão do RCD são privados e os geradores pequenos ou grandes pagam o descarte ou reciclagem através de empresas especializadas. Em alguns, como na Holanda, desde 1997 é vedado o descarte em aterros, ou seja, a reciclagem é obrigatória. Na Espanha e Portugal o descarte é feito em aterros públicos ou privados sendo que as taxas de entrada não podem ser menores que o mínimo dos preços cobrados por aterros privados por caçamba em cada região. No nosso caso, cada município terá autonomia de escolher os procedimentos mais recomendados para se adequar ao "espírito da lei".

Uma mudança no marco regulatório é condição necessária, mas não suficiente para que a cadeia da construção civil absorva estes custos. Os instrumentos econômicos têm que ser dosados adequadamente para que os preços dos reciclados sejam absorvidos de maneira harmônica com o crescimento da cadeia da construção civil.

A experiência internacional mostra que em alguns países em desenvolvimento houve retrocesso dos indicadores ambientais como o descarte ilegal com medidas adotadas na mudança dos paradigmas sem sustentação econômica do mercado da construção civil (Luppi et al., 2012). O retrocesso nestes indicadores ambientais 
acontece também nos países desenvolvidos; com a crise econômica em Portugal e Espanha, o nível da atividade da construção civil sofreu quedas anuais de $20 \%$ nos últimos quatro anos. Em visita às empresas recicladoras espanholas em 2011, como a UTE Planta de Navalcarnero, nas cercanias de Madrid, constatou-se circuitos de produção de agregados reciclados inoperantes e na Galícia, empresas recicladoras desativaram plantas por falta de demanda de reciclado.

\subsubsection{Ciclo do produto}

O marco regulatório traz o conceito do Ciclo de Produto, que em instância legal, vincula a responsabilidade da cadeia da construção civil pelos produtos desde o préuso até a reciclagem ou descarte.

A nível acadêmico, desenvolveu-se um grande número de trabalhos com esta abrangência temporal e com objetivo de fazer um inventário ou um cenário com varias alternativas para a gestão ambiental, onde o foco pode ser um produto como uma edificação ou um serviço como a gestão do RCD de uma cidade ou região e mesmo país. Estes estudos conhecidos como Avaliação do Ciclo de Vida tornaramse uma ferramenta de apoio para a decisão ambiental nos EUA e na União Europeia.

Existe uma Avaliação do Ciclo de Vida (ACV) (Nunes, K. et al., 2010) para a gestão do RCD no município do Rio de Janeiro (onde os impactos medidos foram em relação à Saúde Humana, Recursos Minerais e Combustíveis e Qualidade do Ecossistema). Os cenários considerados foram: reciclagem na fonte de geração dos resíduos com pequenos moinhos, reciclagem em centrais de reciclagem, deposição em cavas de pedreiras e deposição em aterros de resíduos sólidos urbanos. Os resultados da ACV mostram que a combinação de $20 \%$ para reciclagem na fonte de geração e $80 \%$ para as cavas de pedreira têm o melhor desempenho em relação aos impactos ambientais. A pergunta que fica é: como o município produz 618.000 t/ano de RCD e 494.400 t/ano, ou seja, $80 \%$ de RCD seriam destinadas a obturar cavas de pedreira, por quanto tempo seria viável esta decisão? Necessitar-se-ia de uma disponibilidade de volume de cava considerável. Para dar conta desta realidade que ficou complexa pelo número de variáveis e de fatores envolvidos, optamos pela modelagem dinâmica para a gestão do RCD a nível municipal. 


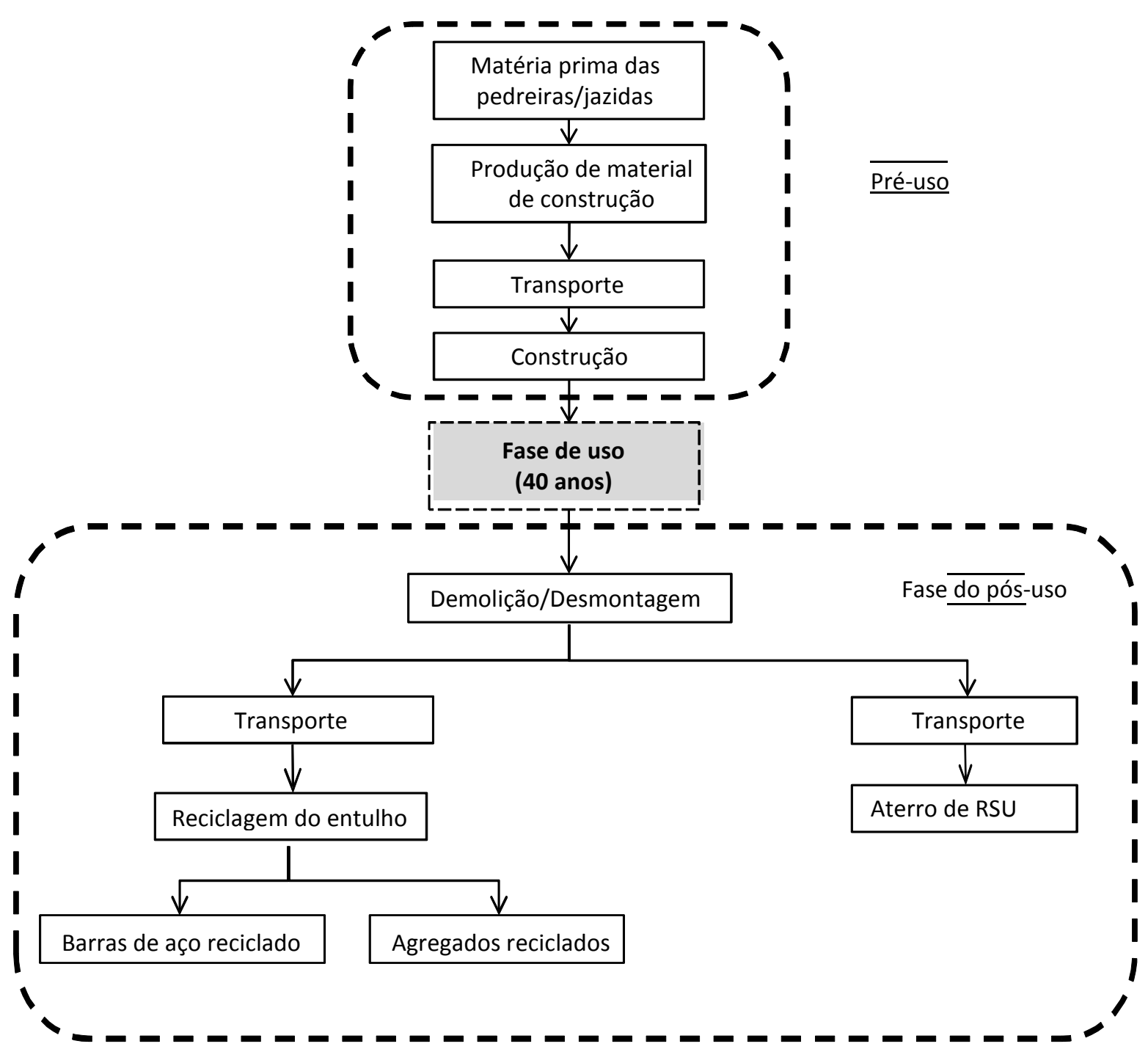

Figura 2.3 - Avaliação do ciclo de vida e dos RCD.

Fonte: Amelia Craighill and Jane C. Powel, Working Paper 99-03.CSERGE 1999

A Figura 2.3 mostra as várias fases que podem ser quantificadas com seus impactos com várias dimensões, desde uma edificação, uma região ou um país.

A tomada de decisão na área ambiental na Comunidade Europeia e nos EUA é comum a nível municipal ou regional e deve se levar em conta estas AVC.

O propósito do legislador brasileiro foi colocar no marco regulatório o Ciclo de Vida para que os outros níveis da governança usem esta ferramenta. 
3. A INDÚSTRIA RECICLADORA EMERGENTE E A MADURA

"De te fabula narratur"

"Esta história nos diz respeito"

Horácio 


\subsection{INTRODUÇÃO}

O objetivo deste capítulo é traçar um paralelo entre duas trajetórias da indústria recicladora de RCD através das semelhanças e diferenças em práticas industriais em usinas onde a reciclagem está em difusão, mas o mercado de reciclados ainda não está consolidado, principalmente nas qualificações dos produtos, as quais se denominaram de emergente e de indústria recicladora madura, onde os agregados reciclados são mercadoria corrente e certificada, dispostos à venda nas lojas de material de construção.

A proposta não tem qualquer caráter determinista, no sentido que a trajetória da reciclagem de RCD no Brasil vai acompanhar pari passu a trajetória da indústria madura, porque o leque de opções é muito amplo para a indústria nascente, começando pelos conteúdos macro estruturais a exemplo dos índices de concreto. Porém, o caminho já percorrido pela indústria madura mostra, a princípio, quais práticas sistêmicas podem ser adotadas e em cada caso aprofundar estudos para sua viabilidade. O pressuposto é que a organização industrial nascente vai deslocar sua fronteira tecnológica juntamente com o nível qualitativo dos produtos para os parâmetros da indústria recicladora madura. Existem estudos (Tam et al., 2009) de práticas dentro de um paradigma da indústria recicladora, comparando Japão versus Austrália, sendo o Japão a referência das melhores práticas. $O$ estudo concentra-se em vários aspectos acerca de reciclados de concreto como o marco regulatório dos mercados, a capacidade empresarial das indústrias da construção civil e a mão de obra especializada que produz e usa estes produtos.

O ponto central é que reciclagem como grande indústria é uma atividade que cresce e se expande nas sociedades pós-industriais no conceito proposto por Bell (1973). Isto é, o dinamismo das economias modernas desloca-se para o setor de serviços e para a economia do conhecimento depois de atravessar todas as fases da industrialização, desde a mais leve como a de bens de consumo, até a pesada como a siderurgia e a de bens de capital. Este movimento do centro dinâmico da economia associado à urbanização é que proporciona a destruição/renovação desta enorme macro estrutura de fábricas, edificações e infraestrutura viária, incorporando a indústria recicladora como setor essencial da economia. 
Esta constatação se aplica ao Brasil de maneira diversa porque o país tem sistema produtivo onde existem subsistemas de diferentes idades produtivas e tecnológicas, às vezes no mesmo ramo industrial, como as siderúrgicas modernas do litoral e os guseiros do interior do país. Por isso, somente algumas regiões com eixo em São Paulo podem ser classificadas de "pós-industriais".

O referencial teórico mais amplo, fora do escopo deste trabalho, é verificar a partir das Industrializações Tardias (Mello, J.M.C,1984), a exemplo da brasileira, como se constitui a indústria recicladora emergente dos RCD. Isto é, como o desenvolvimento industrial, incluindo o da construção civil e a urbanização, formaram o mercado de reciclados e constituem a indústria recicladora emergente com empresas com padrão industrial de grande indústria.

Neste capítulo, a meta é conferir um status teórico à indústria recicladora emergente enquanto organização industrial específica com os seus equipamentos e nível tecnológico de suas plantas, seus procedimentos e como recebe sua matéria prima e produz os agregados reciclados.

A grande maioria das empresas recicladoras e/ou plantas ainda é vinculada ou pertence aos serviços públicos de coleta de Resíduos Sólidos Urbanos, mas este quadro está se transformando. Como exemplo desta realidade, em 2011, fundou-se em São Paulo a ABRECON (Associação Brasileira para Reciclagem dos Resíduos da Construção Civil e Demolição) congregando as empresas recicladoras (cerca de 20) mais importantes do país com estratégias empresariais em consonância com o amplo mercado de agregados reciclados que se descortina a partir do novo marco regulatório.

Uma primeira consideração importante a balizar esta trajetória da indústria emergente é que a urbanização brasileira, de maneira geral, não produziu estruturas urbanas e edificações em que o concreto foi o principal material. As taxas encontradas (veja na Tabela 3.1) são bastante diversas, mas são ilustrativas da composição da fração mineral. Tem-se que relativizar estes dados porque as metodologias de coleta e amostragem são diferentes, pouco abrangentes (a exceção de Macaé) e não consideram resíduos da pavimentação no caso brasileiro.

Por sua vez, a indústria recicladora madura, em geral, produz preferencialmente os reciclados do concreto incluindo os originários da pavimentação com asfalto. 
Estes dados sugerem que a indústria recicladora emergente será diversificada, tanto no ritmo de crescimento quanto na proporção das fases dos reciclados. Como exemplo a nível de pesquisa temos a o trabalho experimental (Ulsen, C. 2011) que trata da separabilidade do RCD para obter agregados reciclados miúdos.

As taxas encontradas em algumas regiões do mundo com na Galícia (Espanha) para concreto são de $29,3 \%$ e cerâmica $44,6 \%$, para Europa como um todo atinge a $39,0 \%$ de concreto, devido à proporção maior de concreto no RCD da Alemanha. Já no Japão 81,8 \% do RCD gerado é concreto.

Tabela 3.1 - Composição do RCD em alguns países.

\begin{tabular}{cccc}
\hline Região & \%Concreto & \%Cerâmica & Fonte \\
\hline Espanha (Galícia) & $29,3 \%$ & $44,6 \%$ & Isabel Martinez Lage et al.,2010 \\
\hline Alemanha & $70 \%$ & - & Coronado, M. et al., 2011 \\
\hline Japão & $81,8 \%$ & - & V. W. Y.Tam, 2009 \\
\hline Holanda & $40 \%$ & - & Coronado, M. et al., 2011 \\
\hline
\end{tabular}

Tabela 3.2 - Composição do RCD no Brasil.

\begin{tabular}{cccccc}
\hline Região & $\begin{array}{c}\% \\
\text { Concreto }\end{array}$ & $\begin{array}{c}\% \\
\text { Argamassa }\end{array}$ & $\begin{array}{c}\% \text { Rochas } \\
\text { e britas }\end{array}$ & $\begin{array}{c}\% \\
\text { Cerâmica }\end{array}$ & Fonte \\
\hline Itatinga - SP & 15,0 & - & - & 38,0 & De Baptisti (1999, p. 113) \\
\hline Ribeirão Preto & 21,0 & 37,0 & 18,0 & 24,0 & Zordan (1997, p.89) \\
\hline Ribeirão Preto & 14,0 & 48,0 & 23,0 & 15,0 & Machado Jr. Et al. (2000, p.4) \\
\hline Santo André & 4,0 & 64,0 & 11,0 & 11,0 & Pinto (1999, p.19 e 20) \\
\hline
\end{tabular}

Esta diversidade de composição sugere uma possibilidade diferente nas trajetórias desta indústria nascente no Brasil, mas que deve ser relativizada porque são dados da macroestrutura urbana e a viabilidade de cada empresa recicladora ocorre por aumento ou escassez de preços dos agregados naturais, custo de transporte e operacionais, ou seja, uma série de preços relativos somente visíveis no cenário micro regional.

\footnotetext{
${ }^{6}$ Isabel Martinez Lage etal. "Estimation of the annual production and composition of C\&D debris" WASTE MANAGEMENT n³0,2010, pag 636-645

${ }^{7}$ Coronado, M.; Dosal, E.;Coz, A; Viguri, J. R.; Estimation of construction and demolition waste (C\&DW) generation and multicriteria analysis of C\&DW management alternatives: a case study in Spain. Waste Biomass Valor 2011 2:209-225

${ }^{8}$ V. W. Y.Tam/Journal of Cleaner Production no17,2009, p. 688-702.
} 
O que é mais relevante para este estudo é verificar as práticas na cadeia da construção civil, como o resíduo é gerado e coletado, e o respectivo tratamento como material alternativo para a transformação em agregado reciclado.

\subsection{PRÁTICA INDUSTRIAL}

A prática industrial da reciclagem de resíduos de construção e demolição objetiva a transformação dos mesmos em materiais aproveitáveis. A maior parte destes resíduos constitui a sua fração mineral (80\% a 95\%), que contém concreto, alvenaria, terra, brita, areia, argamassa, tijolos, azulejos, cerâmica branca e vermelha, gesso, amianto. São também parte destes resíduos o vidro, metais, madeira, plásticos, embalagens, restos de material elétrico e de tubulação.

A principal característica dos RCDs é a variabilidade do material, principalmente dos resíduos mistos. Para reduzir e limitar esta ampla variabilidade, utilizam-se procedimentos seja na área da engenharia civil, seja na área da engenharia mineral.

Tanto em uma área como em outra, desenvolveram-se técnicas de classificação e separação dos materiais do entulho capazes de reduzir esta variabilidade ou, dito de outra forma, de homogeneizar a matéria-prima para obtenção de propriedades físicas nos padrões técnicos adequados ao uso futuro como material substituto dos agregados naturais.

A prática industrial independentemente da localização (no Brasil ou no Exterior) trabalha para atingir a máxima homogeneização dos resíduos. No entanto, a diferença é que na reciclagem emergente a heterogeneidade da alimentação e dos produtos requer circuitos mais simples do que nas indústrias de reciclagem maduras.

\subsubsection{A área da engenharia civil}

Nas usinas brasileiras, a maior parte do material que entra para o processamento é constituída de resíduos mistos, que contêm alvenaria e concreto. No pátio de recepção do entulho são classificados visualmente entre vermelho (com maior parte de materiais cerâmicos como tijolos) e cinza (com a maior parte de material 
cimentício e concreto). Na entrada, não há uma inspeção detalhada da carga porque o preço do descarte na planta é muito semelhante ou idêntico para resíduos de concretos ou mistos que não tenham contaminação.

No exterior, o RCD é taxado na entrada da planta em faixas de preços, tendo em conta a heterogeneidade das fases como concreto, mistos, terra, madeira, metais e uma severa penalidade devido à presença de materiais indesejáveis e contaminantes. Desta forma, cada caçamba contém, na medida do possível, a mesma fase. Nas usinas visitadas, para uma carga ser considerada concreto deve conter no mínimo 95\% da fase para a Espanha e 99\% na Alemanha

Esse diferencial ocorre como resultado da coleta e a Demolição Seletiva (DS). Essas práticas, principalmente a DS, estão diretamente vinculadas à reciclagem e ao reuso.

Para que ocorra a coleta seletiva são destacados os seguintes fatores (Nunes, 2004):

- Tamanho do canteiro para a disponibilidade de espaço para o armazenamento temporário de RCD;

- Prazo da obra;

- Materiais empregados e processos de construção;

- Distância/localização das centrais de reciclagem e de aterros sanitários;

- Existência de mercado para a venda dos materiais resultantes da coleta seletiva.

A Demolição Seletiva é realizada por partes e com desmonte preciso de cada uma delas. Utiliza-se intensivamente de mão de obra especializada e ocorrem as seguintes etapas:

- Retirada de materiais com risco de contaminação, materiais a segregar-se;

- Materiais passíveis de valorização;

- Demolição da estrutura;

- Selagem de fossas;

- Modelagem do terreno.

A experiência internacional (Tam et al., 2009) mostra que a separação na fonte 
geradora dos resíduos é indispensável para a obtenção de reciclados com melhor qualidade.

Os dois procedimentos acima não são de fácil implantação, devido ao tempo e ao trabalho gasto, mas tornam-se fundamentais para aumentar a qualidade dos produtos.

A partir dos anos 80, a Alemanha, país com muita pesquisa e experiência na reciclagem, difundiu em larga escala a tecnologia e os bens de capital dedicados à produção dos agregados reciclados. Em uma revisão de Tränkler et al.(1996) sobre o período anterior de dez anos passados, assinala que, no início, para a grande indústria alemã da reciclagem, não era evidente que a demolição seletiva era um obstáculo econômico a ser ultrapassado em busca da melhoria da qualidade dos reciclados, porque o baixo custo das técnicas de demolição tradicional produzindo agregados heterogêneos satisfazia o mercado. Mas o que era exceção no início, ou seja, a combinação de técnicas de demolição seletiva tinha se tornado regra comum na indústria, transcorrido este período, devido as exigências de produtos mais elaborados no mercado de agregados reciclados.

Em Hong Kong, onde não existe disponibilidade de terrenos para descarte, POON et al. (2001) relata que os construtores/demolidores foram relutantes na separação de resíduos nos canteiros de obra e demolições e não foi suficiente impor pesadas multas para quem não a realizasse. Foi necessário modificar a legislação específica, obrigando-os a executar estas práticas.

Em resumo, a experiência internacional registra que, em determinado momento, a cadeia da construção civil torna viável a Coleta e a Demolição Seletiva, porque consegue praticar os preços relativos aos reciclados de alta qualidade em condições competitivas aos naturais.

No Brasil, a Demolição Tradicional é a regra e os serviços públicos nem mesmo fazem registro da qualidade do material demolido, poucos municípios fazem de volumes aproximados e a maioria não há registro qualquer acerca de demolições/renovação. Em geral, os municípios cobram uma taxa de demolição de acordo com área demolida, que passa para a condição de terreno apto para receber novos projetos. 
A coleta não é seletiva e uma dificuldade adicional na quantificação é a quantidade de resíduos de geração informal que não passa por qualquer controle, segundo Pinto (1999), é uma parcela importante dos resíduos gerados nos municípios.

A nova Política Nacional dos Resíduos Sólido (PNRS) prioriza a Coleta e a Demolição Seletiva e cabe aos municípios implementá-las. Cumpre destacar que as taxas de descarte do resíduo heterogêneo são muito baixas em geral e são necessários estudos de viabilidade sistêmica, para lograr êxito nesta mudança. Empresas de demolição consultadas que realizam Demolição Seletiva, o fazem de maneira artesanal, com custos bem superiores para os clientes que a solicitam. Uma das maiores dificuldades na área é a mão de obra especializada, porque a Demolição Seletiva é uma combinação de técnicas de demolição, desmonte e separação das partes construídas, como uma logística reversa da construção que exige marceneiros, pedreiros, eletricistas, responsáveis pelo isolamento térmico, encanadores e outros. Este é um desafio para a indústria da construção civil brasileira, visto que estas práticas são ligadas não só a qualidade do agregado reciclado, mas também a quantidade do que é reciclado, porque, nesta mudança, há um ganho em escala do mercado dos reciclados, pois se torna mercadoria corrente para diferentes áreas da indústria civil muito além da base para pavimentação.

\subsubsection{A área da engenharia mineral}

$\mathrm{Na}$ área da engenharia mineral, o Tratamento de Minérios subsidia os procedimentos adotados nas plantas recicladoras.

Segundo Chaves,A.P. (2002), "o tratamento dos minerais é o conjunto de operações unitárias de redução de tamanhos, separação de tamanhos, separação de espécies minerais e separação de sólidos e líquidos, bem como a arte de combiná-las em fluxogramas de modo a obter concentrados e produtos aceitáveis pelo mercado".

As usinas das empresas recicladoras, a exemplo das mineradoras, realizam estas operações unitárias através dos equipamentos combinados para tratar os resíduos visando sua nova utilização. Devido à extensa variabilidade do RCD, a combinação destes equipamentos difere das encontradas nas mineradoras, mas a maioria destes equipamentos é oriunda desta indústria, com algumas adaptações devido às características do material. 
As principais operações da Tecnologia Mineral aplicada na reciclagem seriam (Chaves et al., 2006):

- Separação por tamanho: peneiramento com peneiras vibratórias ou peneira rotatória e trommel (encontrado na empresa Solos) quando a eficiência das peneiras for prejudicada por grande quantidade de partículas planas como plásticos ou filamentosas como barbantes e fibras;

- Cominuição: britadores convencionais como de impacto, cônicos, mandíbulas com certa predominância dos de impacto como primários. Vem sendo usado o "sizer" que é uma modificação do britador de rolos dentados ou do "feeder breaker" utilizado na mineração subterrânea. Britadores não convencionais como VSI;

- Concentração gravítica: realizada por jigues industrialmente em Usinas no exterior e como aparelhos de pesquisa no IPT, USP e no CETEM;

- Eliminação de finos: realizada por classificadores em espiral e ciclones;

- Catação: realizada manualmente em esteiras;

- Sorting ótico: separa as partículas por cor, equipamento de alto preço.

As plantas das recicladoras são de dois tipos: móveis e fixas.

\subsection{COMPARAÇÃO DOS FLUXOGRAMAS DE OPERAÇÃO ENTRE AS RECICLADORAS NA INDÚSTRIA RECICLADORA EMERGENTE E NA MADURA}

As operações envolvidas nas empresas consistem nas operações de catação (sorting), redução do tamanho das partículas (britagem), separação das partículas em classes de tamanho, eliminação de elementos indesejáveis, manuseio dos resíduos entre as operações sucessivas a seco e operações a úmido como separações gravíticas (por jigagem) ou densitária (classificação espiral). No Brasil somente a Usina do Socorro apresenta processo a úmido de separação densitária com classificador espiral. 


\subsubsection{Recepção do RCD}

No pátio de recepção do entulho são classificados visualmente entre vermelho (com maior parte de materiais cerâmicos como tijolos) e cinza (com a maior parte de material cimentício e concreto).

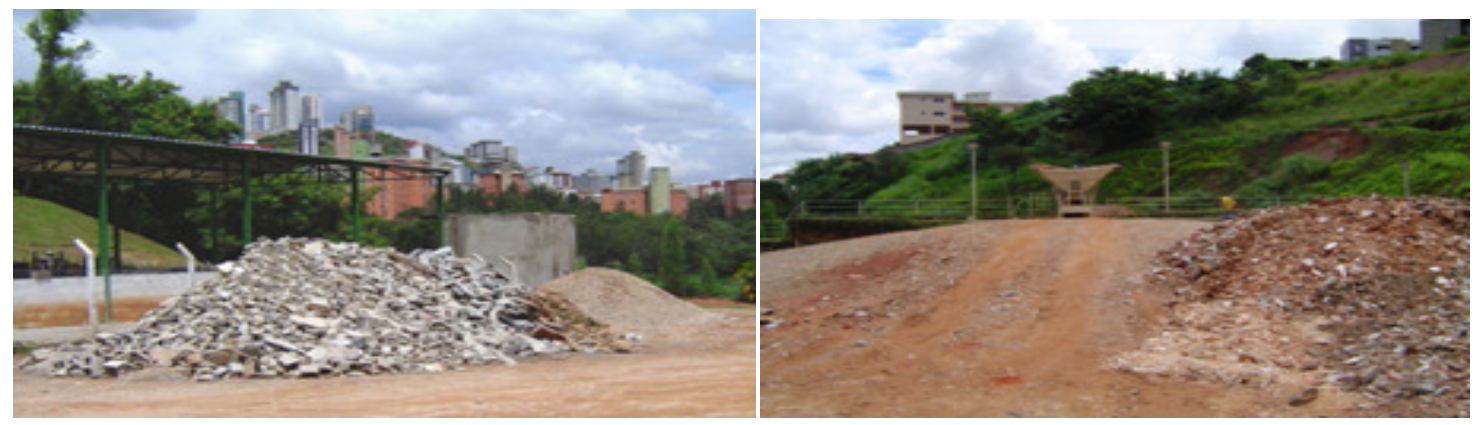

Figura 3.1 - Pátio de recepção de RCD cimentício e RCD cerâmico.

Entrada na usina de reciclagem: a triagem nas usinas é feita por inspeção visual das caçambas.

No Brasil, as plantas têm chuveiros na entrada para abater poeiras no pátio de recepção. As balanças de caçambas existem em poucas usinas, mas elas praticamente não são usadas.

O valor da taxa de entrada da carga tem pouca variação e muitas vezes não é cobrada quando se trata de concreto limpo. Quando existe quantidade considerável de material classe B e C (Resolução 307/2002) a carga é rejeitada.

O RCD mineral é geralmente classificado como RCD cinza (predominância de matérias cimentícios) e vermelho (predominância de cerâmica vermelha). O material é disposto no pátio segundo esta classificação.

No exterior, a carga é pesada, sendo posteriormente feita uma inspeção visual e, sobre a carga, é definida uma taxa de entrada. Esta taxa é relacionada à heterogeneidade do material (quanto maior volume de concreto, menor a taxa), aos materiais indesejáveis como gesso e aos contaminantes como amianto, os quais são segregados. As diferenças das taxas de reciclagem são acentuadas principalmente na presença de contaminantes. Quando há divergência, é feita uma amostragem expedita para definir a taxa de entrada. Não existe rejeição da carga, pois são cobrados valores diferenciados. 


\subsubsection{Catação}

As caçambas aceitas com predominância do RCD mineral apresentam ainda uma parcela de material orgânico leve, que necessita ser removida, e vidro. Esta catação, nas usinas nacionais, é feita no chão, antes da cominuição, como na Usina da BR040 em Belo Horizonte. Após a cominuição, ela pode ser feita sobre transportadores de correia, como na usina da empresa Solos de Americana/SP. A colocação da catação na saída do britador diminui sua eficiência pela poeira ambiente.

A catação, no exterior, é feita após a britagem, mas existem equipamentos como os separadores pneumáticos abatedores de poeira (Windshift) que separam, retiram e extraem os papéis, folhas e plásticos, antes de qualquer operação de cominuição.

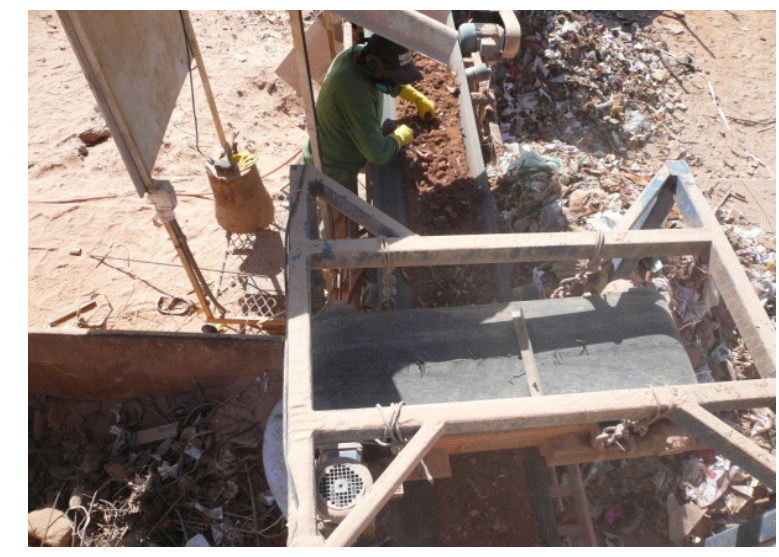

(a)

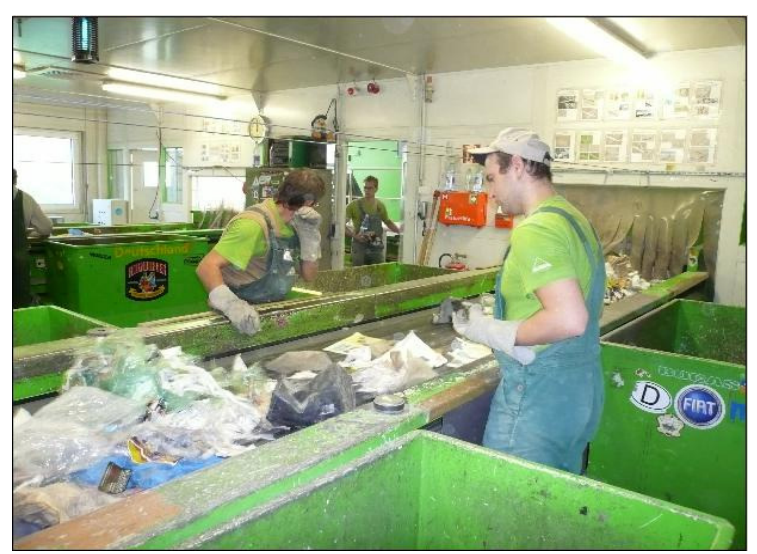

(b)

Figura 3.2 - (a) Ambiente aberto, catação em esteira (Usina da CEMARA, Americana-SP); (b) Ambiente fechado, com esteira e abatimento de poeira (Usina da AMAND, Dresden, Alemanha).

\subsection{ESCALPE + BRITAGEM + PENEIRAMENTO: COMPARAÇÃO DAS PLANTAS BH-BR-04 E AMAND EM DRESDEN NA ALEMANHA}

Serão analisadas conjuntamente estas operações em uma comparação entre as plantas da Usina da BR-040 em Belo Horizonte, que pertence a uma autarquia do Serviço de Limpeza Urbana da Prefeitura Municipal de Belo Horizonte, com a de Amand, em Dresden, Alemanha. A planta brasileira, a maior planta operando no Brasil, ocupa pequena porção em uma imensa área da Prefeitura onde se encontra 
o aterro controlado de descarte dos resíduos domiciliares. A fração não mineral descartada da recicladora de RCD é encaminhada para o aterro controlado.

A planta da Amand é uma das cinco maiores recicladoras com plantas fixas de grande porte para RCD com sede na cidade de Dusseldorf. A empresa recicla outros resíduos que são recolhidos no comércio e em escritórios como papel, vidro, vasilhame pet e de alumínio, tecidos, madeira (mas não domiciliares) em uma planta vizinha e recebe estes materiais que são descartados da planta de reciclagem e RCD.

As duas Usinas têm layout com aproveitamento da gravidade para a alimentação dos britadores, sendo que em Dresden foi construído um prédio com esteira rolante para alimentação e o material no pátio de estocagem é coberto. Em Belo Horizonte, a planta é a céu-aberto e foi aproveitada uma cava, sendo que alimentação é realizada por cima, aproveitando o desnível do terreno.

Nas duas plantas de reciclagem de RCD os equipamentos têm as mesmas capacidades iniciais dos britadores de martelo de 100t/h. A catação em BH é realizada antes da britagem no chão e em Dresden na sala com abatimento de poeira onde passa a esteira após britagem.

Nas duas existem escalpe sendo que $\mathrm{BH}$ é um escalpe inicial do material para uso na pavimentação como rachão. Na Amand é pelo top size de britagem.

Em Belo Horizonte existe um britador cônico secundário quando o material é de qualidade para reciclados de concreto. Os RCD concreto ficam acumulando em pilha e a britagem e peneiramento funcionam quando material é solicitado, não é contínua.

O produto principal de $\mathrm{BH}$ é a bica corrida com $80 \%$ da produção, segundo informações da SLU e em Dresden reciclados de concreto.

As operações são quase idênticas e os equipamentos idem. Em BH temos britagem secundária e a catação em esteira em Dresden é mais eficiente.

Afora estes detalhes, a diferença que salta aos olhos é a heterogeneidade das alimentações e dos produtos obtidos no caso brasileiro e a homogeneidade dos concretos obtidos na empresa Amand em Dresden. 


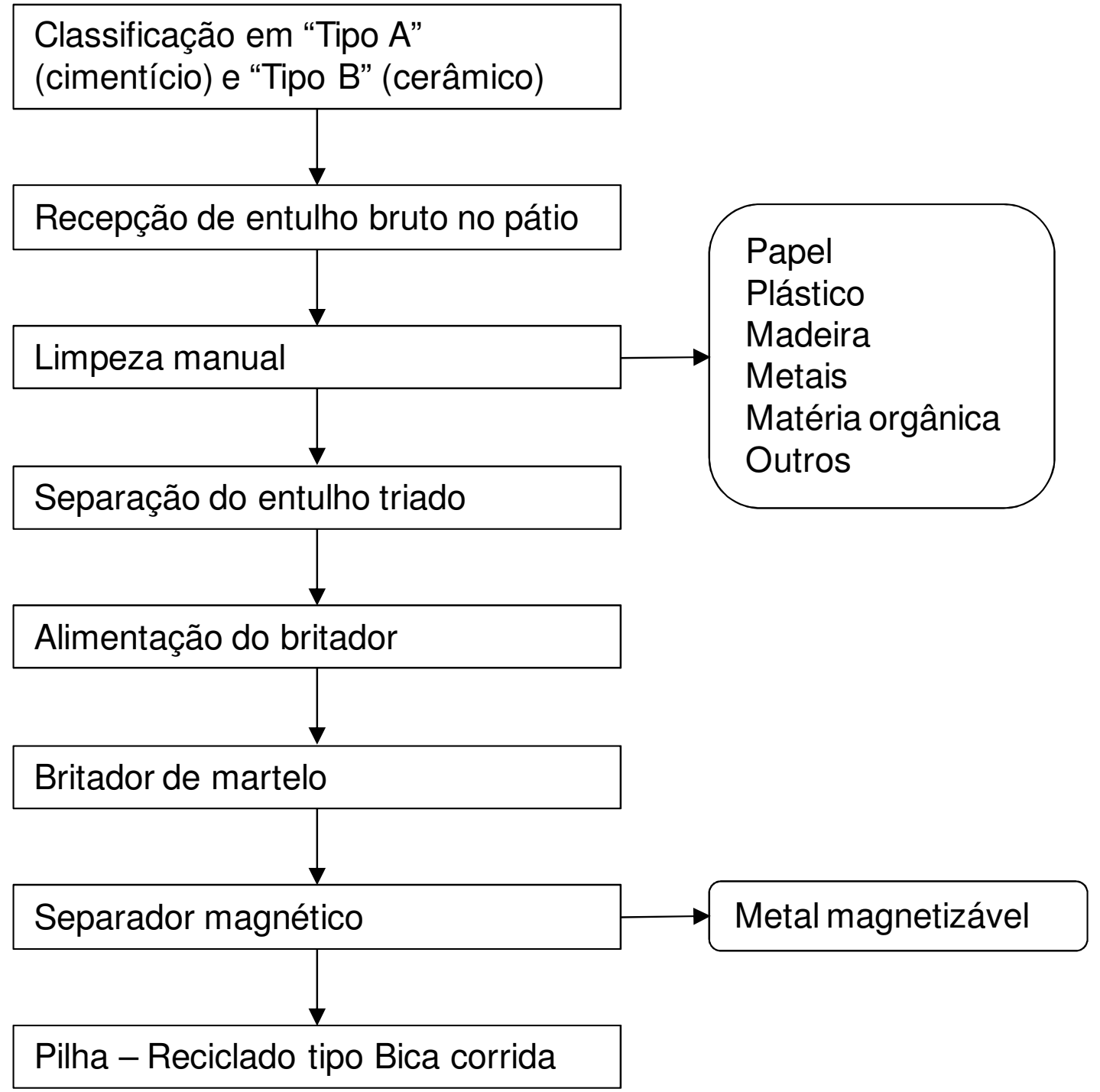

Figura 3.3 - Circuito das Usinas de Belo Horizonte.

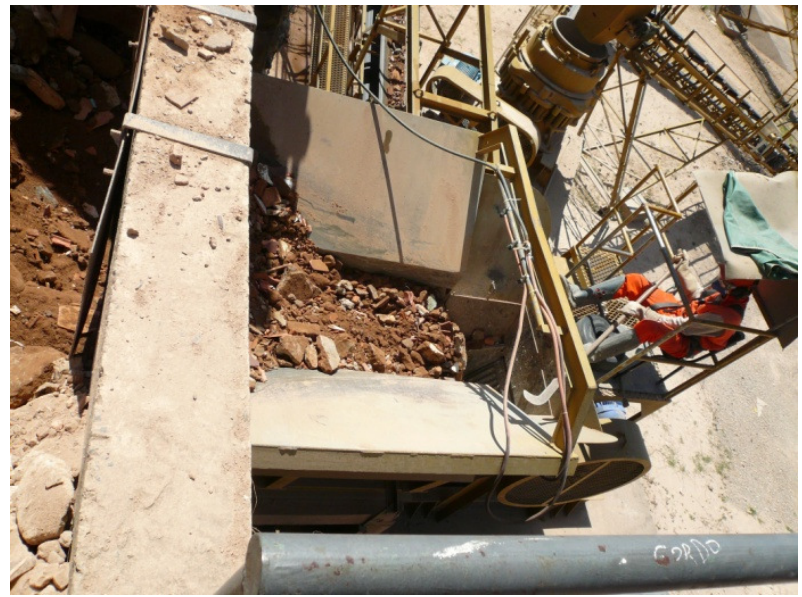

(a)

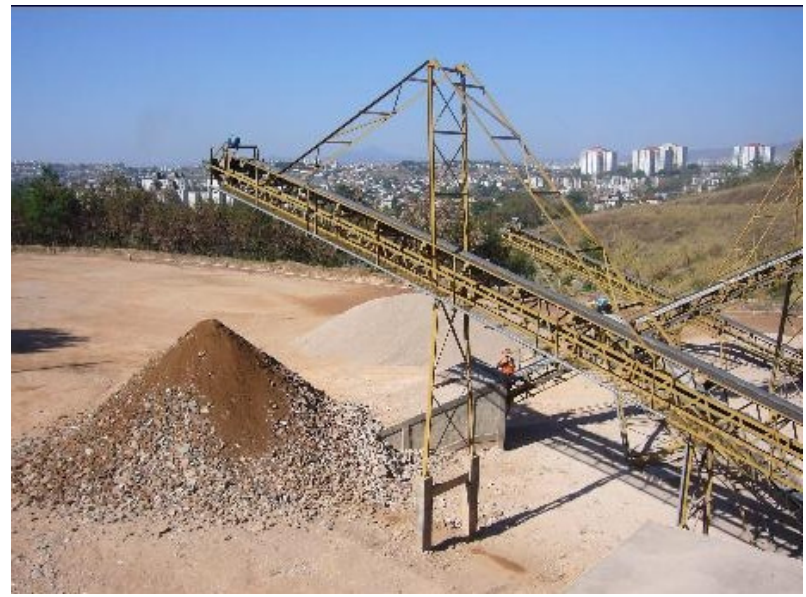

(b)

Figura 3.4 - Detalhes da Usina BR-040: (a) escalpe/britador martelo e ao fundo britador cônico (secundário); (b) produto na forma de bica corrida e ao fundo, na última pilha, aparece a brita reciclada. 


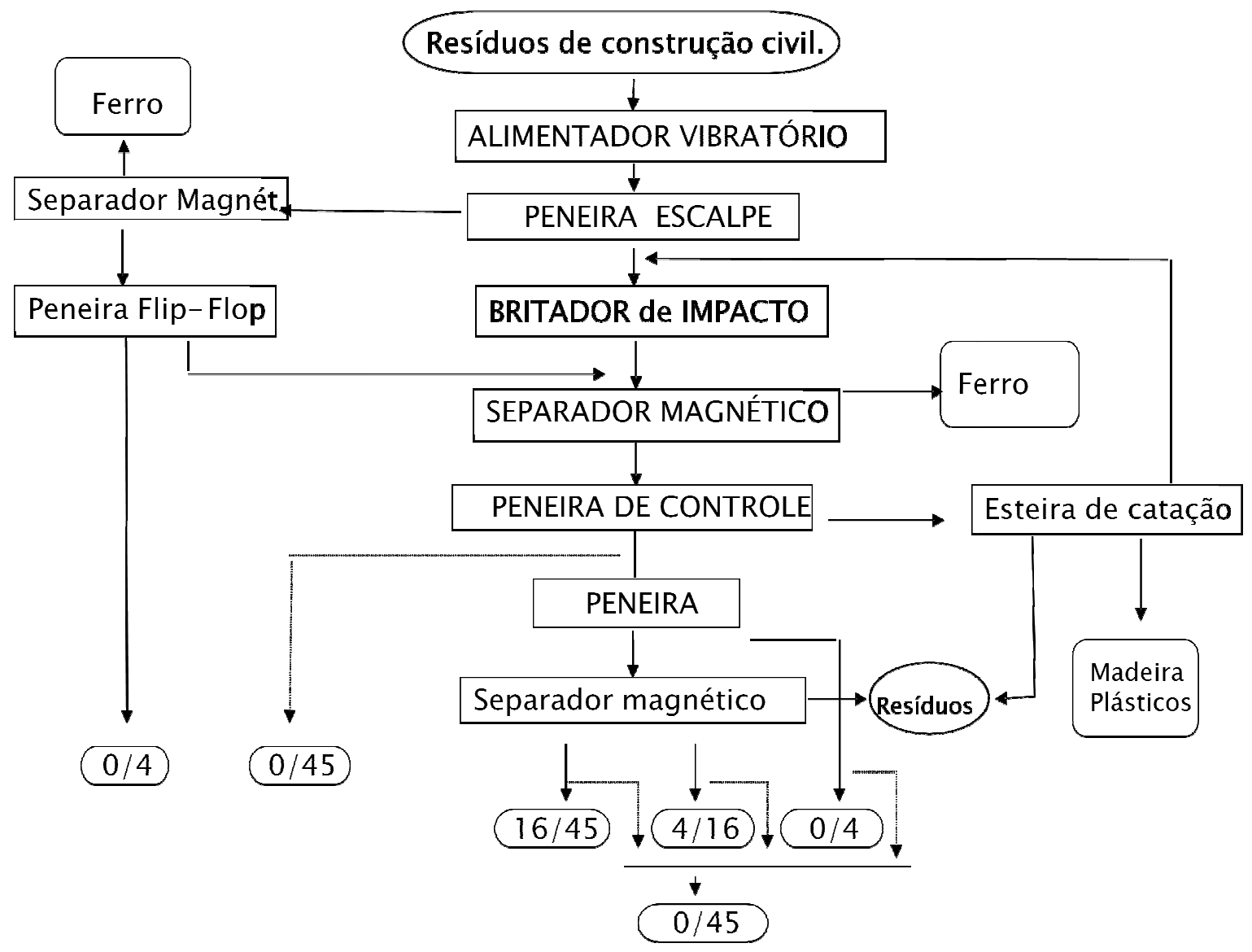

Figura 3.5 - Fluxograma de processamento da Amand, Dresden, Maxener Strasse. Os números acima são as dimensões mínima e máxima (em $\mathrm{mm}$ ) dos produtos da reciclagem.
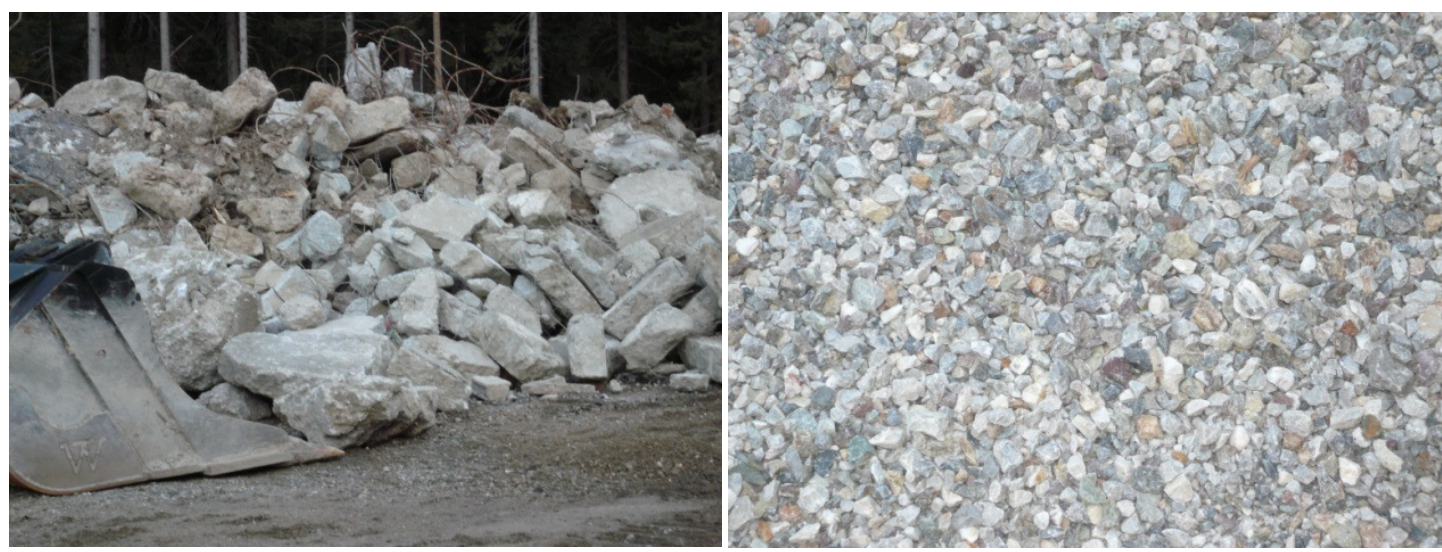

Figura 3.6 - Alimentação e produtos da Amand. 


\subsubsection{Jigagem}
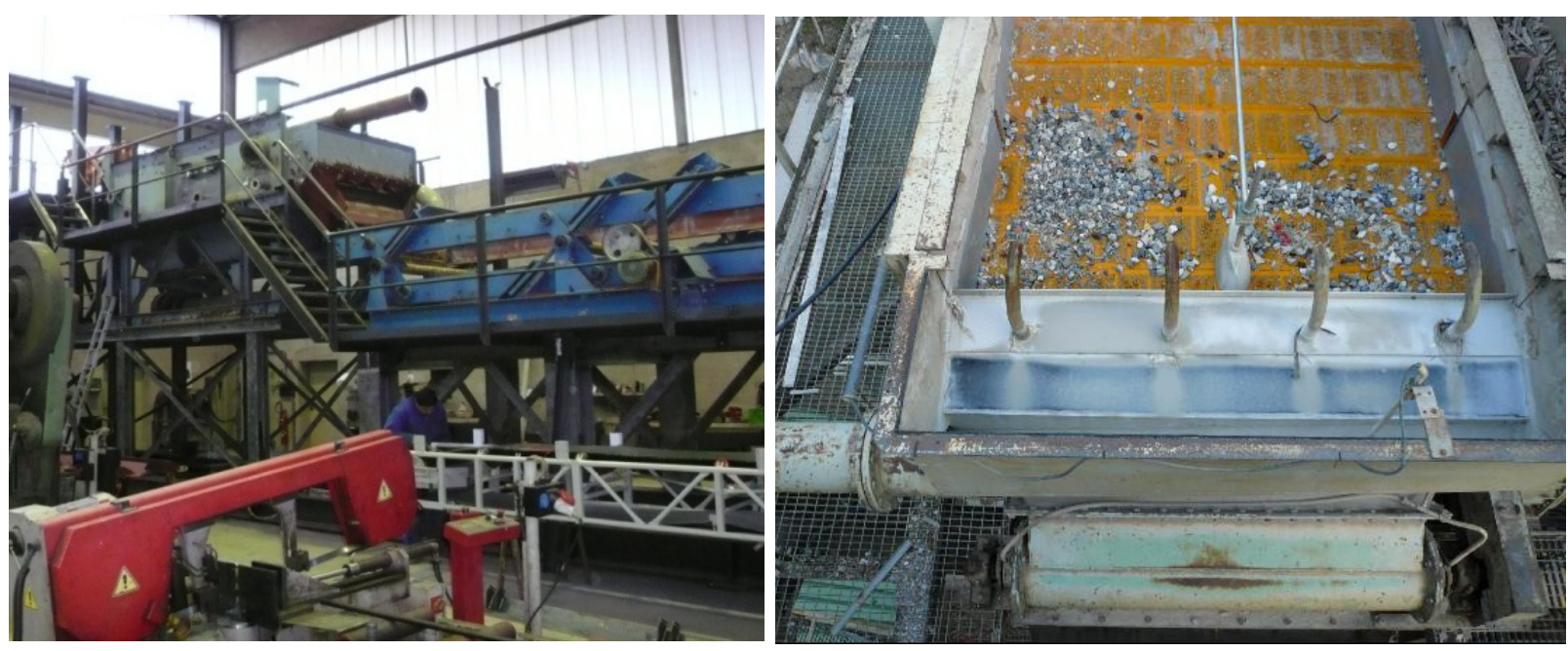

Figura 3.7 - Jigues da Deisl-Beton, Salzburg, Áustria.

Os jigues são equipamentos de concentração gravítica largamente utilizados para produzir agregados reciclados graúdos de concreto na indústria recicladora madura e a separação densitária é feito entre a brita ser reciclada e o material leve. Ângulo cita Derks et al. afirmando que usar o jigue permite produzir um agregado com menos de $0,01 \%$ de materiais orgânicos leves, que é impossível de ser obtido através do uso de classificadores pneumáticos, o que permite aos produtos serem utilizados como agregados para concretos.

Na Usina "VAR", na Holanda, estes dois equipamentos ilustrados na Figura 3.7 são utilizados conforme fluxograma de operação abaixo. A planta processa separadamente concreto e alvenaria.

Após a britagem e separação magnética, o material passa em um classificador pneumático (Windshift), o agregado é alimentado verticalmente e ar em contra corrente transporta os materiais leves e finos na direção contraria ao fluxo dos pesados. Após passar por peneira de $5 \mathrm{~mm}$ para retirada da fração miúda, é novamente peneirada em malha de $32 \mathrm{~mm}$, retirando uma fração $+32 \mathrm{~mm}$ que é vendida como rachão. $A$ fração $-32,+5 \mathrm{~mm}$ passa em um jigue Baum para retirada de material leve. O material afundado posteriormente é peneirado em duas frações $16+5 \mathrm{~mm}$ e - 32+16mm de reciclados graúdos. 


\subsubsection{Comparação esquemática entre circuitos típicos da indústria recicladora}

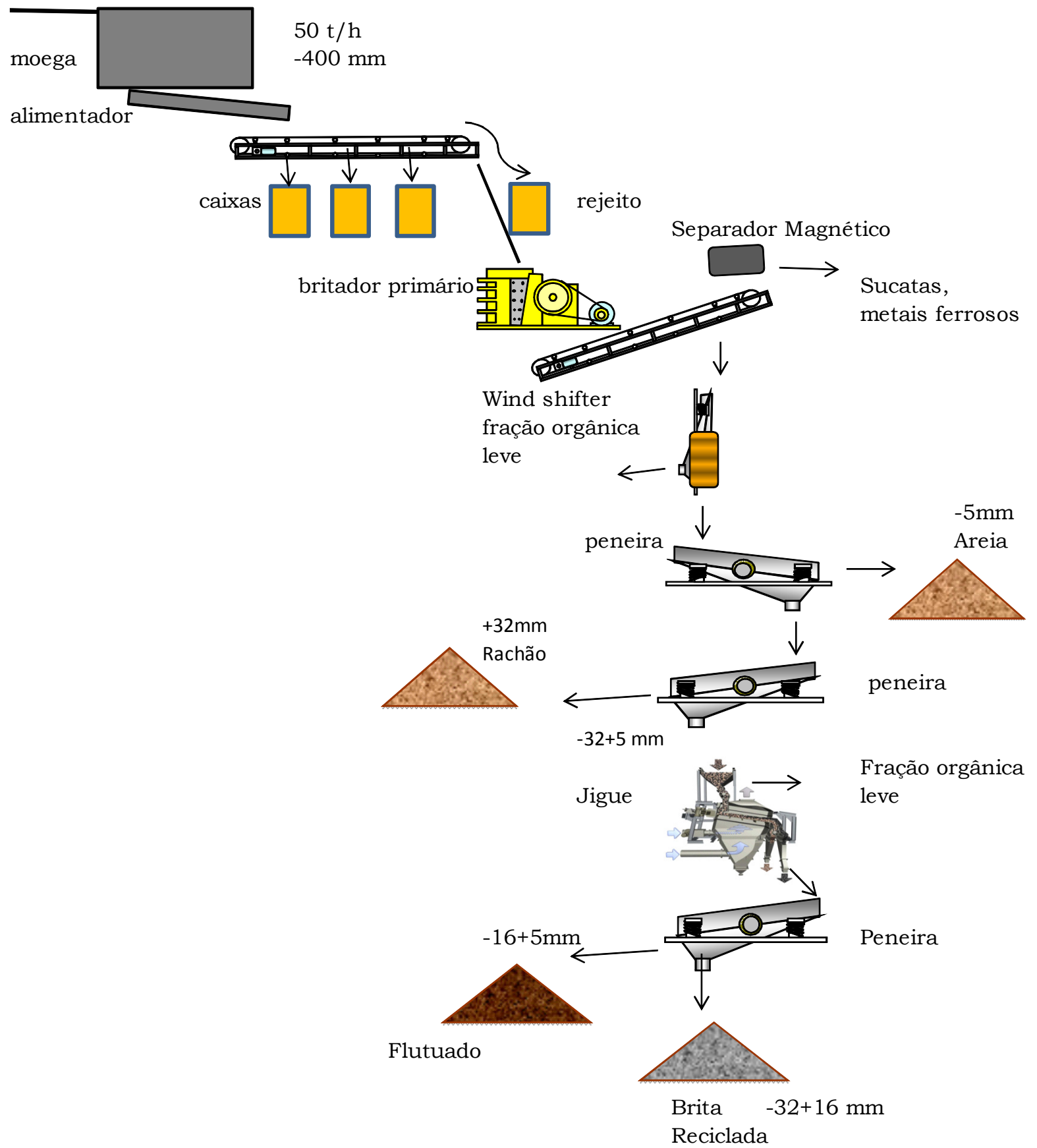

Figura 3.8 - Circuito típico da indústria recicladora madura existente na Alemanha e Holanda para obtenção de brita de concreto.

Fonte: Adaptada Usina VAR em Ângulo et al., ENARC 2009 


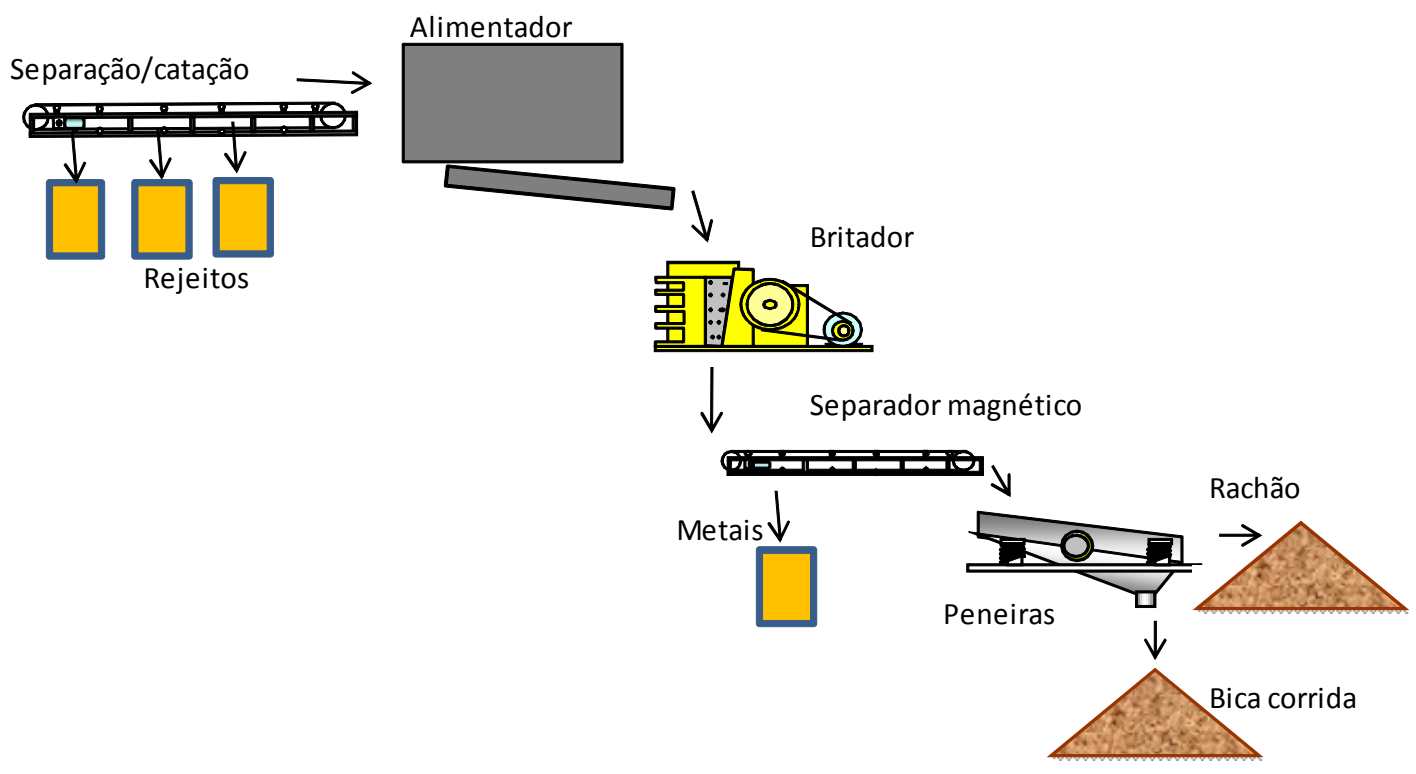

Figura 3.9 - Circuitos típicos da indústria recicladora emergente em países como Brasil e China para produção de bica corrida e rachão.

Fonte: o autor.

Os dois fluxogramas de processamento mostram equipamentos diferentes como 0 classificador pneumático e o jigue para redução das proporções de finos e de materiais orgânicos leves para adequar o agregado reciclado nas normas vigentes nas indústrias da construção civil maduras. Estes equipamentos ainda não são utilizados no Brasil.

A comparação das Usinas da Amand em Dresden e da SLU em BH, plantas com fluxogramas e equipamentos semelhantes e nas plantas acima com equipamentos diferenciados assinalam que a diferença decisiva da indústria emergente para a madura está na alimentação dos RCDs devido à demolição e a coleta seletiva.

Isto é, na indústria emergente, a barreira à entrada de equipamentos com custo operacional mais elevado como jigues e espirais reside antes do portão de entrada das recicladoras, isto é, na alimentação de resíduos mistos. Não se está referindo a uma empresa brasileira que ocasionalmente adota um destes equipamentos, mas do ponto de vista sistêmico principalmente do ponto de vista regulatório, ÂnguloS. C. e John,V. M. (2001) analisaram 36 amostras de agregados graúdos da Usina de Santo André observando características físicas e composição por fases com os critérios das normas japonesa e holandesa. Concluíram que nenhuma das amostras se enquadravam para concretos com resistência superior a $25 \mathrm{MPa}$, mas que $50 \%$ 
delas poderiam ser utilizadas para concretos com resistência inferior a 25MPa.

Em se tratando da pesquisa, a equipe composta por pesquisadores do CETEM e USP produziu brita de qualidade concreto em operações de jigagem usando resíduos mistos. Estas britas recicladas foram testadas para concreto estrutural no trabalho de Moreira, L. (2010).

Porém nas pesquisas acima, o resíduo misto alimentado no jigue foi selecionado em lotes denominados de alta qualidade com corte na densidade $d>2,2$ na amostra, realizado previamente no "Sink and floaf". Qualquer operação com este tipo de procedimento em equipamento industrial como o tratamento no tambor de meio denso está fora de consideração devido ao baixo valor da tonelada da brita reciclada em comparação com o custo da operação.

Não é suficiente existir normas técnicas acerca de reciclados para que auditores regulatórios públicos ou autorregulatório das empresas recicladoras certifique produtos nas condições de grande variabilidade por lote a fim de oferecer a confiança para a substituição parcial dos agregados naturais na produção de concreto em larga escala. A montagem do sistema de certificação de qualidade na rede de consumo de reciclados no Brasil está em processo de estudos do caráter puramente público ou parceria público-privada no caso da auto-regulamentação.

A experiência internacional mostra que países líderes na área como Alemanha e Japão fizeram a transição para a produção de reciclados de melhor qualidade usando mecanismos econômicos e fazendo com que e os custos da demolição seletiva e coleta seletiva fossem incorporados harmonicamente no desenvolvimento da cadeia da construção. A experiência de Hong Kong mostra que não bastaram estes mecanismos e a transição foi gerida com a imposição administrativa por parte da governança ambiental na gestão do RCD.

Em qualquer experiência, a cadeia da construção civil tornou viável a Coleta e a Demolição Seletiva, porque conseguiu, no longo prazo, praticar os preços relativos dos reciclados de alta qualidade em condições competitivas com os naturais. 


\section{TRABALHO EXPERIMENTAL}

"O que é familiar não é conhecido simplesmente porque é familiar" Hegel 


\subsection{INTRODUÇÃO}

O objetivo deste capítulo é de se obter parâmetros do que significa a reciclagem de RCD entendida como uma mineração urbana em três cidades brasileiras com diferentes padrões construtivos e, portanto, uma proporção diversa dos materiais empregados. As cidades selecionadas para os estudos foram Macaé, Maceió e uma região recebedora de entulhos na cidade de São Paulo.

Em primeiro lugar foram realizadas amostragens para obtermos o que seria o RCD médio, isto é, o mais representativo no tocante às proporções de cada fase nas cidades amostradas.

Em segundo lugar foram processadas, na Usina Piloto do CETEM, alíquotas representativas das três cidades, objetivando determinar qualidade e nível de contaminantes destes entulhos.

No tocante à qualidade, após inspeção visual (cinza e vermelho) e balanço de massa para concreto e outros materiais, seus números proporcionais seriam próximos ao procedimento que será justificado a seguir.

Os parâmetros qualitativos dizem respeito à valoração do entulho como matéria prima no uso como agregado reciclado. No caso brasileiro com grande quantidade de RCD misto acarreta uma produção significativa de um agregado chamado bica corrida.

Os estudos sobre os materiais reciclados mostram que sua porosidade é um indicador das propriedades futuras em concretos, como a resistência à compressão, módulo de elasticidade, absorção de água, índice de vazios e consumo de cimento (Carrijo, 2005).

Quando se realiza a separação em fases, ou seja, como concreto, cerâmica e argamassa, o comportamento do material apresentará diversidade, mesmo dentro da mesma fase, por exemplo: para o concreto a relação água/cimento, tempo de cura influenciam suas propriedades; acontece o mesmo com material cerâmico que, devido a sua origem, elementos componentes, o tempo e a temperatura de queima dos tijolos e ladrilhos conferem propriedades diversas, como exemplo para o 
abrasão e a resistência.

Pesquisadores da Universidade de São Paulo (Ângulo et al., 2009) estabeleceram níveis de porosidade dos agregados reciclados relacionados às densidades dos mesmos. Os ensaios de "sink and float" com as densidades de corte conforme o diagrama abaixo:

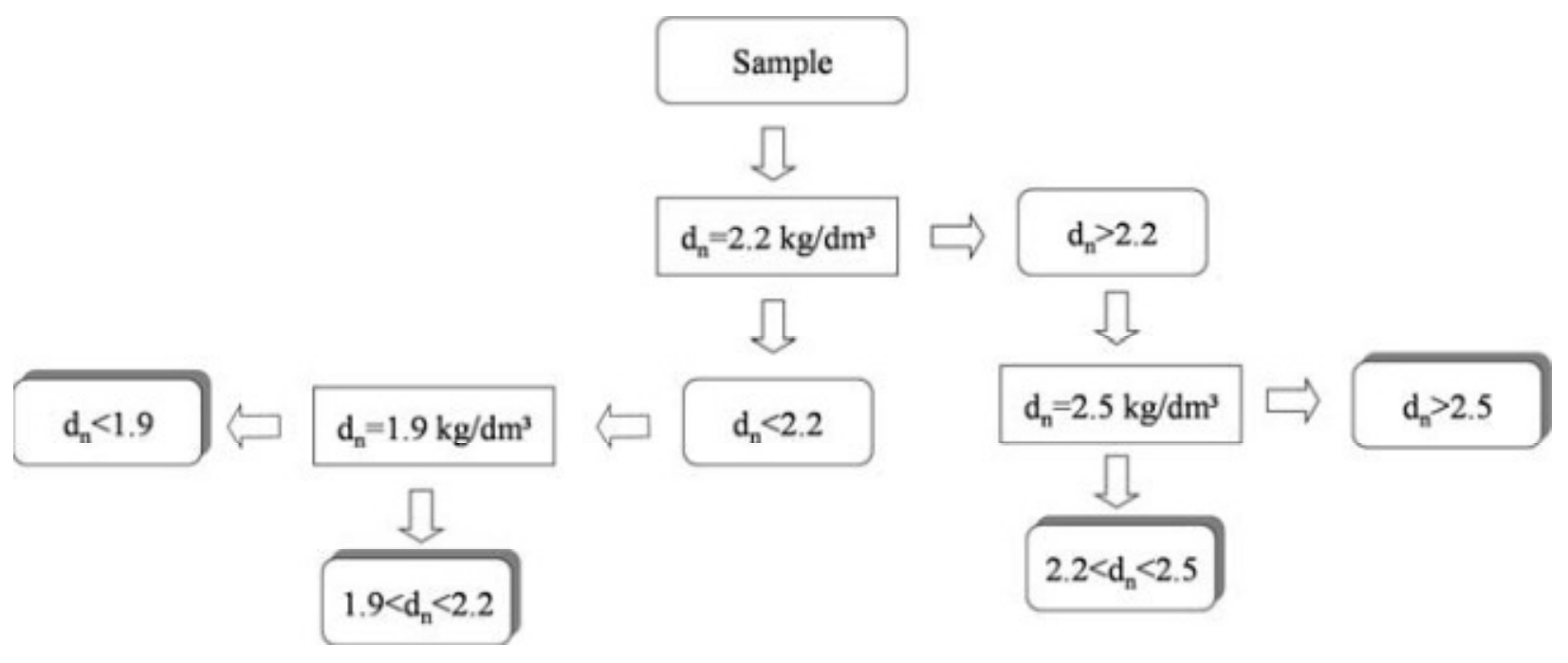

Figura 4.1 - Diagrama dos ensaios de sink and float com as densidades de corte.

Os resíduos mistos são os mais importantes entre nós, não só pela quantidade, mas também porque, inexistindo clientes com necessidades determinadas, os resíduos são, em geral, utilizados na base e sub-base da pavimentação. Usamos estes valores para caracterizar o que seriam as qualidades dos RCDs através de amostragens realizadas em cidades no Brasil.

Em primeiro lugar, no percentual da sua fração mineral e nesta fixamos três níveis de qualidade, correspondendo a três intervalos de massa específica, ou seja: alta, média e baixa qualidade, correspondendo a $\mathrm{Aq}>2,2 ; 1,9<\mathrm{Mq}<2,2 ; \mathrm{Bq}<1,9$. Estes valores foram determinados por pesquisadores da USP.

Como anteriormente observamos na prática industrial, estes intervalos correspondem a uma escala de valor como matéria prima no uso futuro no mercado de agregado. Outra dimensão é a presença de contaminantes e material indesejável que depreciam o valor do RCD

A cidade onde a amostragem foi mais aprofundada foi Macaé, porque se considerou o volume do entulho histórico nos locais tradicionais de descarte da cidade e o RCD 
novo através do sorteio proporcional das caçambas/ dia das empresas coletoras de entulho da cidade.

Em Maceió e São Paulo amostrou-se somente o RCD novo com o mesmo método do sorteio. Para a pesquisa em São Paulo, correspondeu a um local de recebimento de entulho.

\subsection{AMOSTRA REPRESENTATIVA DOS RCDS DE MACEIÓ, SÃO PAULO E MACAÉ E ANÁLISE DA SUA VARIABILIDADE.}

\subsubsection{Procedimentos adotados:}

a) Escolha das cidades de estudo: Macaé (RJ), Maceió (AL) e São Paulo (SP).

b) Definição de uma amostra representativa.

c) Diagnóstico e seleção das principais áreas de descarte e empresas removedoras de RCD.

d) Elaboração de premissas e um procedimento para coleta, preparação e redução de amostras.

e) Coleta e classificação das amostras nas três cidades.

\subsubsection{Definição da Amostra representativa}

Coletar uma massa mínima de amostra é fundamental para reduzir a heterogeneidade do material segundo a teoria de Pierre Gy (Petersen et al., 2005), o que elimina um dos principais erros presentes na amostragem. Isso é fundamental para amostrar o RCD mineral porque os materiais orgânicos são menos densos que os materiais minerais e seus teores na composição são relativamente baixos $(<1 \%$ da massa). A massa representativa pode ser estimada pela equação (1) abaixo.

$$
M=\frac{x \times(100-x) \times \rho \times l \times f \times h \times d^{3}}{S a^{2}}
$$


Em que:

M é a massa (gramas).

x é o teor dos materiais orgânicos leves (gramas/gramas -\%);

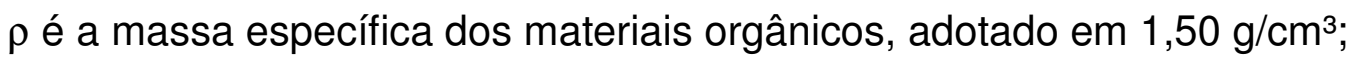

I é o fator de liberação das partículas $(1,0)$, já que os materiais leves orgânicos encontram-se separados dos materiais minerais;

f é o fator de forma das partículas, com valor usual em torno de 0,5.

h é o fator de distribuição de tamanho de partículas, adotado em 0,25.

d é a dimensão máxima (em $\mathrm{cm})$ dos fragmentos.

Sa é o desvio-padrão $(0,05)$.

A Figura 4.2 mostra a massa mínima representativa das amostras em função do teor dos materiais orgânicos leves e a dimensão máxima dos fragmentos. Assim, foi definida uma dimensão máxima para a amostra de $20 \mathrm{~cm}$. Nesse caso, a amostra mínima representativa é de 150 toneladas $\left(115 \mathrm{~m}^{3}\right.$ ou 23 caçambas de $\left.5 \mathrm{~m}^{3}\right)$ para cada cidade. 


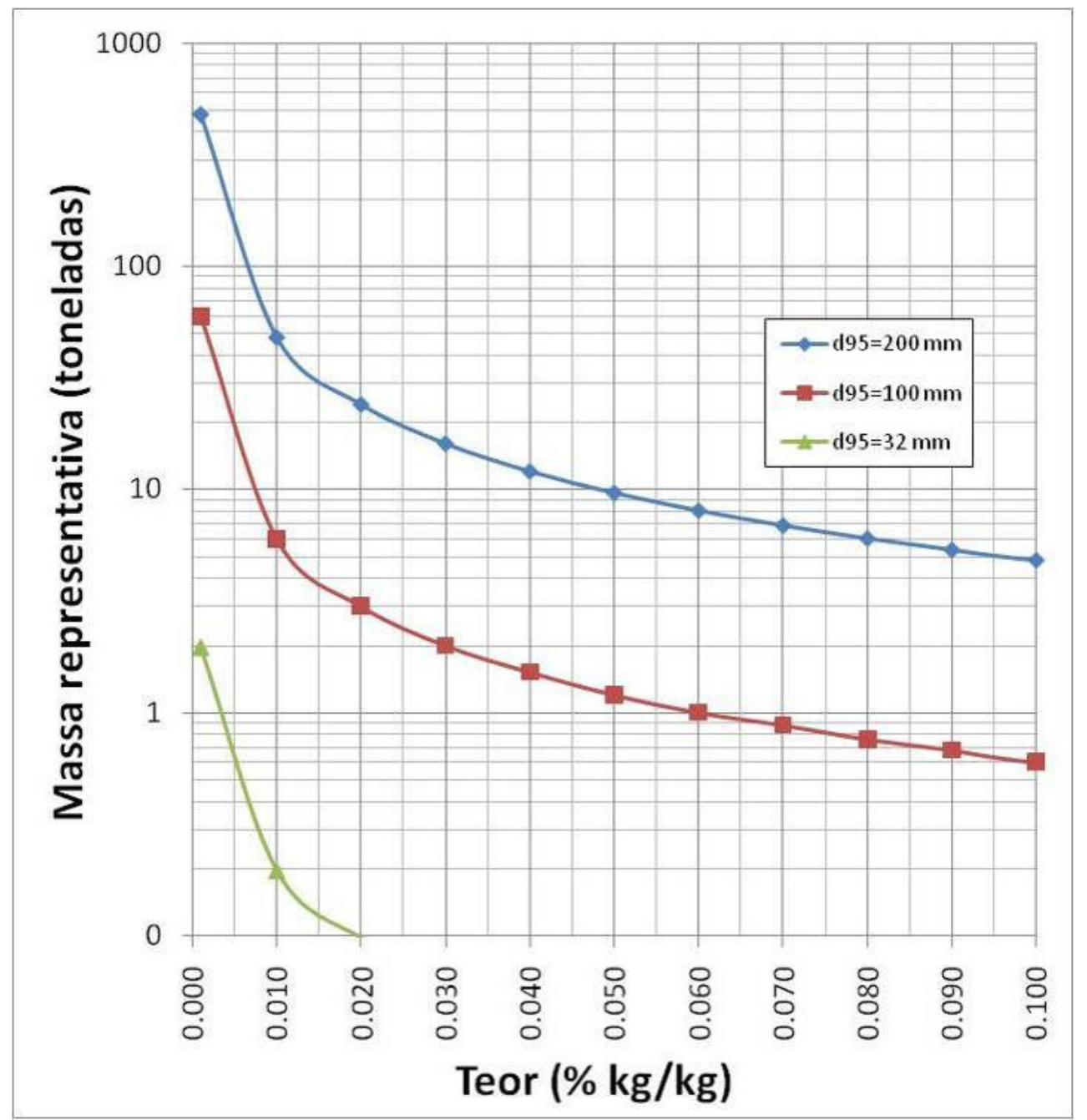

Figura 4.2 - Massa mínima representativa da amostra em função do teor de materiais orgânicos leves e a dimensão máxima dos fragmentos.

Fonte: Angulo; Mueller, 2008.

\subsubsection{Premissas}

- Considerou-se RCD mineral todo o lote que contenha mais de $50 \%$ do volume de materiais minerais (concreto, argamassa, cerâmica vermelha);

- Procurou-se manter o volume de cada lote fixo em $5 \mathrm{~m}^{3}$, através de avaliação visual nas áreas de descarte e volume das caçambas das empresas removedoras;

- O lote de RCD mineral foi coletado sem qualquer processo de triagem, para se avaliar o grau de contaminação por materiais orgânicos leves (papel, plástico e madeira) gesso e cimento amianto; 
- Os fragmentos do RCD mineral maiores que $20 \mathrm{~cm}$ foram reduzidos manualmente com o objetivo de manter a massa coletada dentro dos limites estipulados de representatividade.

\subsection{MUNICÍPIO DE MACAÉ}

Macaé, situada no litoral norte do Estado do Rio de Janeiro, é a cidade principal da exploração do petróleo no país. O dinamismo populacional advindo da descoberta na Bacia de Campos de grandes campos petrolíferos na última década é evidente. $O$ censo do IBGE de 1970 apresentava 65mil habitantes, trinta anos depois, em 2000, registrava 132 mil habitantes e, em uma década, em 2010, havia 206 mil habitantes. A cidade antes pacata como escoadouro do açúcar de Campos e núcleo de pescadores passa a abrigar cerca de 1.000 empresas do ramo petrolífero. $O$ ritmo de construção e demolição da infraestrutura e prédios para receber estas empresas e seus funcionários com elevada média salarial, na orla urbana, foi concomitante com o crescimento de uma periferia, terra adentro nas margens do Rio Macaé.

\subsubsection{Seleção dos locais de amostragem}

Inicialmente, um diagnóstico das áreas de descarte de RCD (Tabela 4.1) foi realizado para a definição do procedimento de amostragem.

As áreas do BABAL e BR-101 recebiam principalmente o RCD dos grandes geradores (edifícios multi-andares), demolições e pequenos geradores de alto poder aquisitivo. São originados de bairros como Jardim dos Cavaleiros, Bairro da Glória, Praia Campista, Centro entre outros. A área do Parque Aeroporto recebia principalmente o RCD em caminhões coletados da limpeza pública (deposições clandestinas na cidade), o que inclui os pequenos geradores de baixo poder aquisitivo. Em locais de ocupação clandestina na cidade, parte do RCD é utilizada como material de aterro para nivelamento do terreno. A área do Babal foi selecionada para a amostragem por receber grande quantidade do RCD antigo gerado na cidade acumulada nos últimos três anos de descarte. 
Tabela 4.1 - Principais áreas de deposições irregulares de RCD da cidade de Macaé

\begin{tabular}{lll}
\hline Local & $\begin{array}{l}\text { Quantidade } \\
\text { de RCD } \\
\text { recebido }\end{array}$ & Origem do RCD \\
\hline BABAL & ++++ & Coleta de caçambas de grandes geradores \\
\hline BR-101 & ++++ & Coleta de caçambas de grandes geradores \\
\hline PARQUE AEROPORTO & ++++ & $\begin{array}{l}\text { Coleta de deposições irregulares na cidade } \\
\text { (Prefeitura) }- \text { inclui pequenos geradores }\end{array}$ \\
\hline AEROPORTO INFRAERO & ++ & Presença significativa de resíduo de gesso \\
\hline ÁGUA MARAVILHOSA & ++ & $\begin{array}{l}\text { Presença de resíduo doméstico de natureza } \\
\text { orgânica }\end{array}$ \\
\hline $\begin{array}{l}\text { BAIRRO DA GLÓRIA - } \\
\text { GURGEL }\end{array}$ & ++ & $\begin{array}{l}\text { Resíduos de canteiros de obras (grandes } \\
\text { geradores) }\end{array}$ \\
\hline MORADA DAS GARÇAS & ++ & $\begin{array}{l}\text { Resíduos de canteiros de obras (grandes } \\
\text { geradores) }\end{array}$ \\
\hline
\end{tabular}

A Tabela 4.2 apresenta as principais empresas transportadoras na cidade de Macaé, com base nos dados fornecidos sobre movimentação de caçambas. As empresas Transbal e Transforma foram selecionadas para a amostragem por transportarem grande quantidade do RCD novo gerado na cidade.

Assim, a amostragem foi dividida em duas etapas: a) Amostragem I - coleta na área do "Babal" do RCD antigo, através da seleção aleatória de pilhas cônicas com aproximadamente $5 \mathrm{~m}^{3}$; b) Amostragem II - coleta horária aleatória de RCD novo de diferentes locais da cidade, num período de fevereiro a junho de 2006, a partir de caçambas de $5 \mathrm{~m}^{3}$.

Tabela 4.2 - Coleta privada do RCD por empresa de caçambas estacionárias, por dia, na cidade de Macaé

\begin{tabular}{ccccc}
\hline & TRANSBAL & TRANSFORMA & OUTRAS & TOTAL \\
\hline $\begin{array}{c}\text { Caçambas transportadas de RCD } \\
\text { (unidades/dia) }\end{array}$ & 18 & 10 & 10 & 38 \\
\hline RCD transportado $\left(\mathrm{m}^{3} / \mathrm{dia}\right)$ & 90 & 50 & 50 & 190 \\
\hline RCD transportado $\left(\% \mathrm{~m}^{3} / \mathrm{dia}\right)$ & 47,4 & 26,3 & 26,3 & 100,0 \\
\hline
\end{tabular}

$R C D$ per capita $=\left(190 \mathrm{~m}^{3} / \mathrm{dia} \times 365 \mathrm{dias} / \mathrm{ano}\right) /(152.063$ habitantes $)=0,45 \mathrm{~m}^{3} / \mathrm{hab}$.ano $R C D$ per capita $=0,45^{\star} 1,3 \mathrm{t} / \mathrm{m}^{3}=585 \mathrm{~kg} / \mathrm{hab}$.ano

Na primeira amostragem - área do "Babal" (Figura 4.3) - foram identificados 85 lotes de RCD de aproximadamente $5 \mathrm{~m}^{3}$, distribuídos em três locais distintos (42 lotes no local 1, 34 lotes no local 2, e 9 lotes no local 3). 


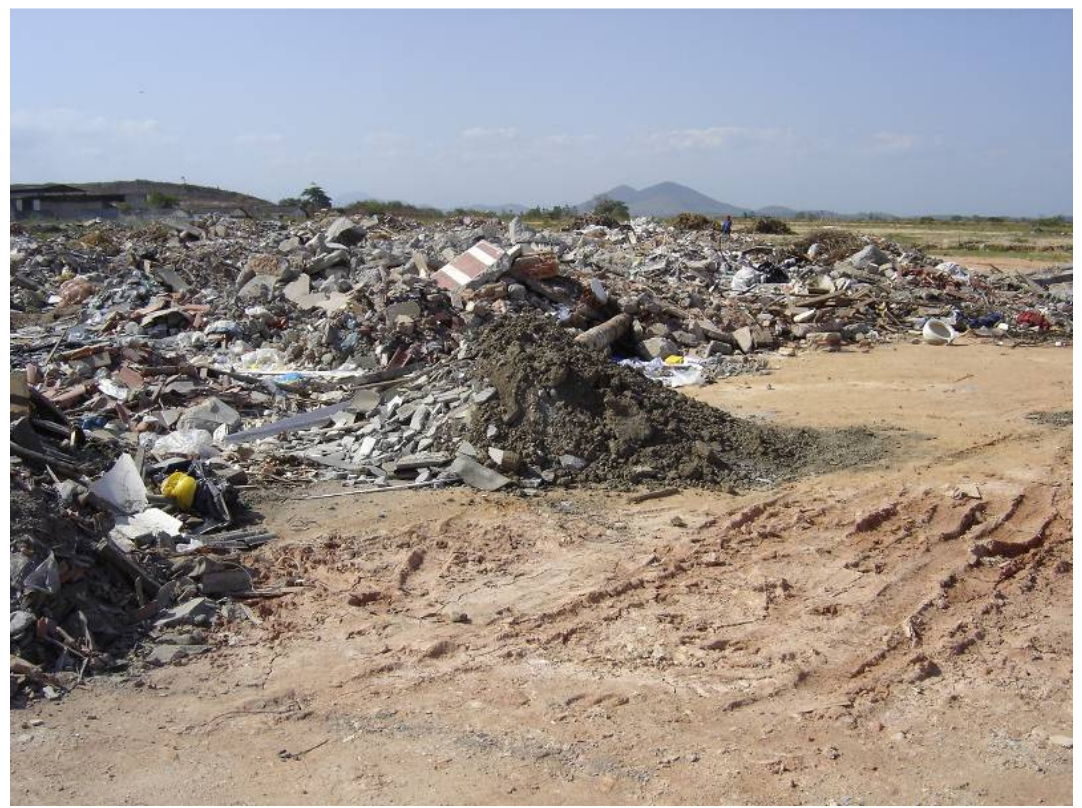

Figura 4.3 - Vista da área do Babal, na cidade de Macaé.

Foram selecionadas 27 caçambas aleatoriamente para a amostragem, correspondendo a 30,5\% do total dos lotes: 11 lotes no local 1 (Figura 4.4), 13 lotes no local 2 (Figura 4.5), 3 lotes no local 3 (Figura 4.6). Os lotes selecionados foram transportados para um local para preparação e redução de amostras.

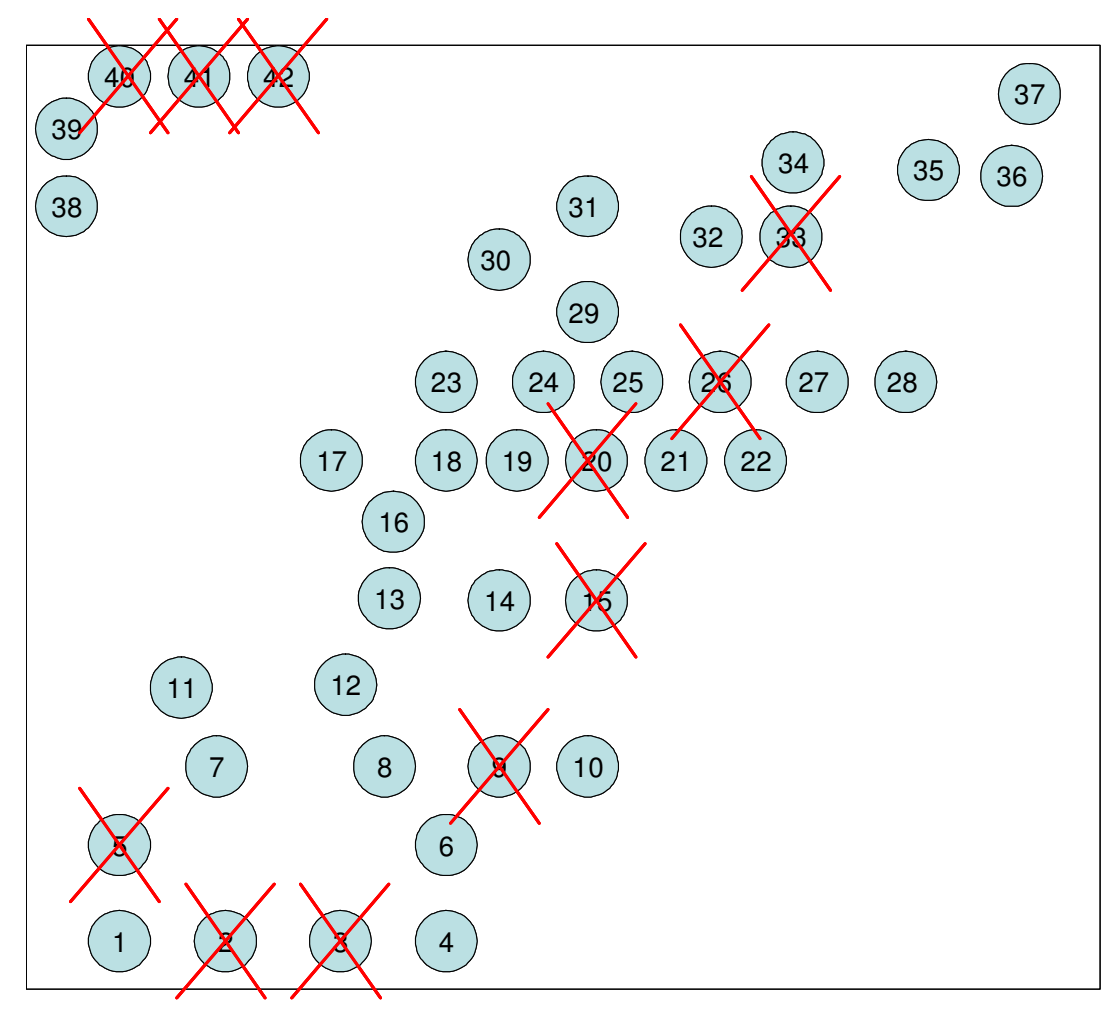

Figura 4.4 - Seleção aleatória dos lotes no local 1 


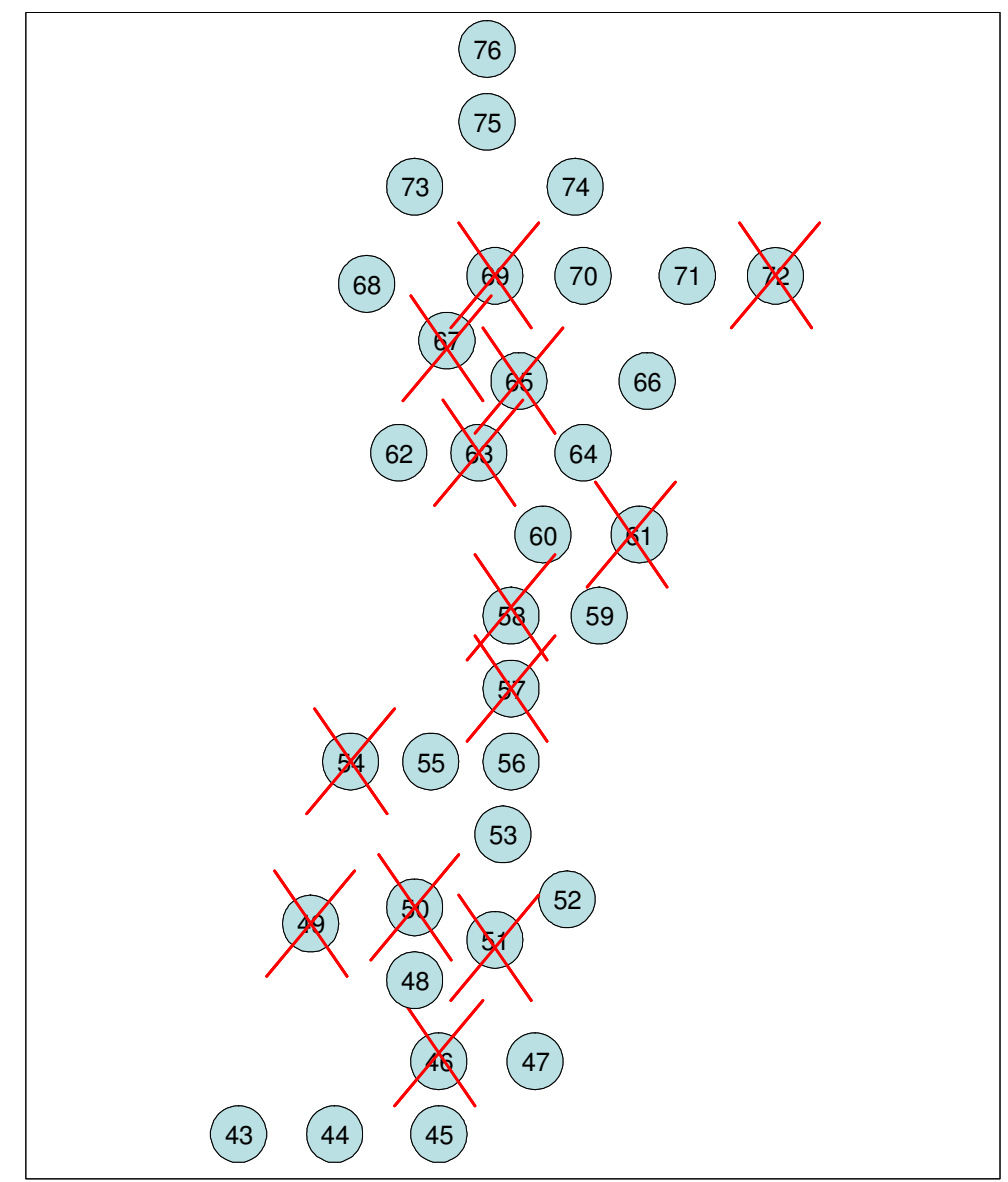

Figura 4.5 - Seleção aleatória dos lotes no local 2.

(82) 85

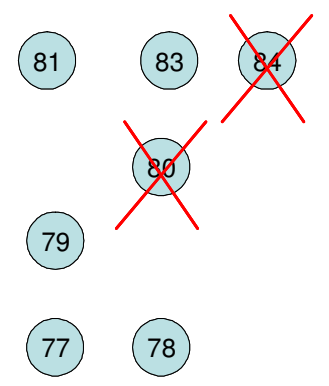

Figura 4.6 - Seleção aleatória dos lotes no local 3.

Na segunda amostragem, a coleta do RCD das empresas transportadoras (Figura 4.7) foi realizada no local de redução e preparação de amostras em três períodos distintos no ano de 2006: a) de 24 a 28 de abril - coleta de 15 caçambas; b) de 08 a 12 de maio - coleta de 8 caçambas; de 5 a 9 de junho - coleta de 7 caçambas. Foram descartadas um total de 6 caçambas por conterem quase que exclusivamente RCD que não poderia ser reciclado como agregado - cimento 
amianto, gesso, madeira, papel, ou por serem compostas exclusivamente por agregados naturais (areia) que não contém agregado reciclado, resultando em 24 caçambas.

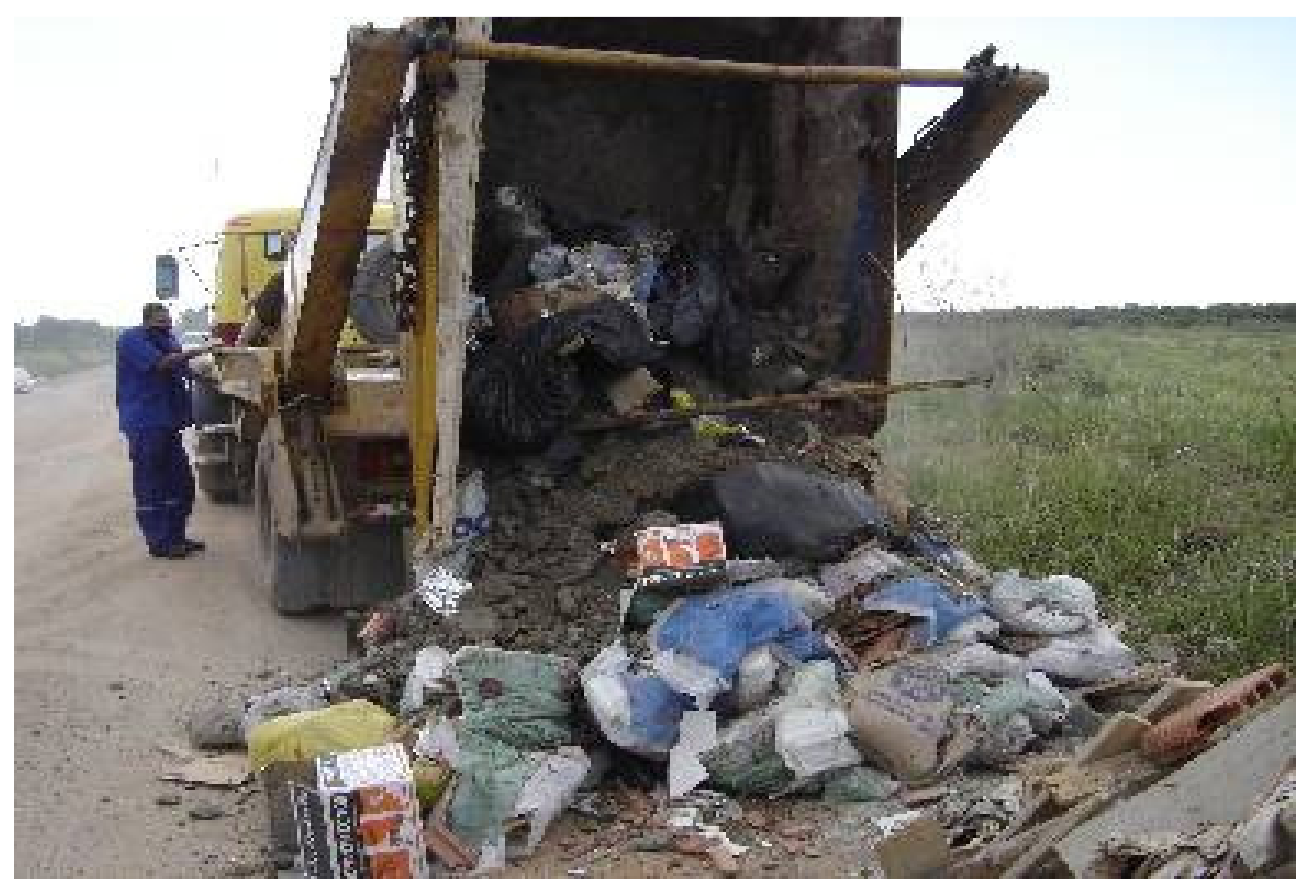

Figura 4.7 - Coleta do RCD das empresas transportadoras.

\subsubsection{Critérios de classificação dos lotes}

Os lotes amostrados foram classificados, quando possível, segundo os seguintes critérios:

- Cor: cinza e vermelho;

- Materiais minerais principais: concreto, argamassa ou cerâmica vermelha;

- Presença de outros materiais: materiais orgânicos (madeira, plástico, papel). contaminantes (gesso ou cimento amianto) ou solo.

\subsubsection{Redução e preparação das amostras}

A Figura 4.8 mostra o local de redução e preparação das amostras na cidade de Macaé. 

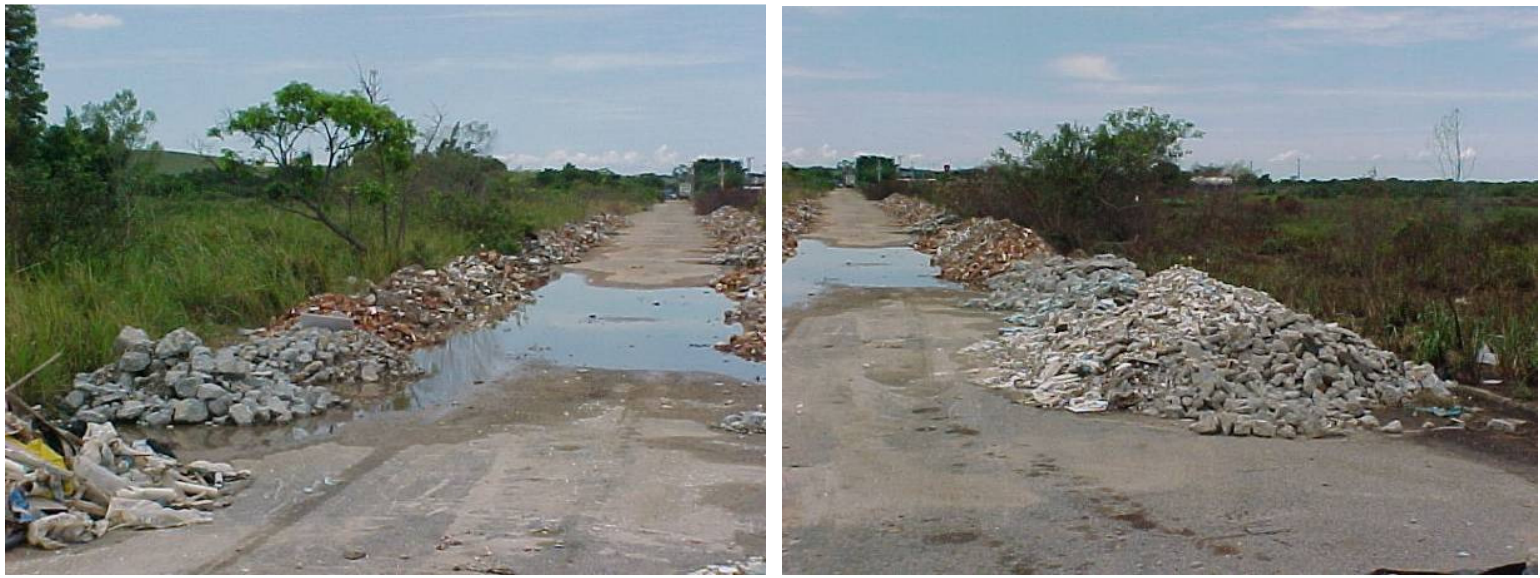

Figura 4.8 - Local de redução e preparação de amostras na cidade de Macaé.

O material com dimensão maior que $20 \mathrm{~cm}$ foi reduzido com o auxílio de um martelete pneumático, como mostra a Figura 4.9 (a). Os materiais indesejáveis foram triados e armazenados separadamente, Figura 4.9 (b), com o objetivo de facilitar o procedimento de redução da amostra. Eles foram reduzidos empregando serras para corte da madeira e do aço, sendo $1 / 3$ do volume separado para a amostragem.

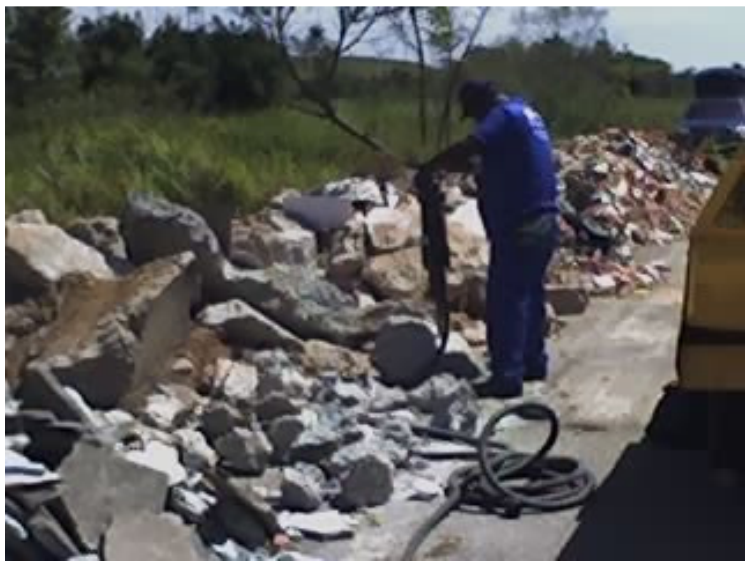

(a)

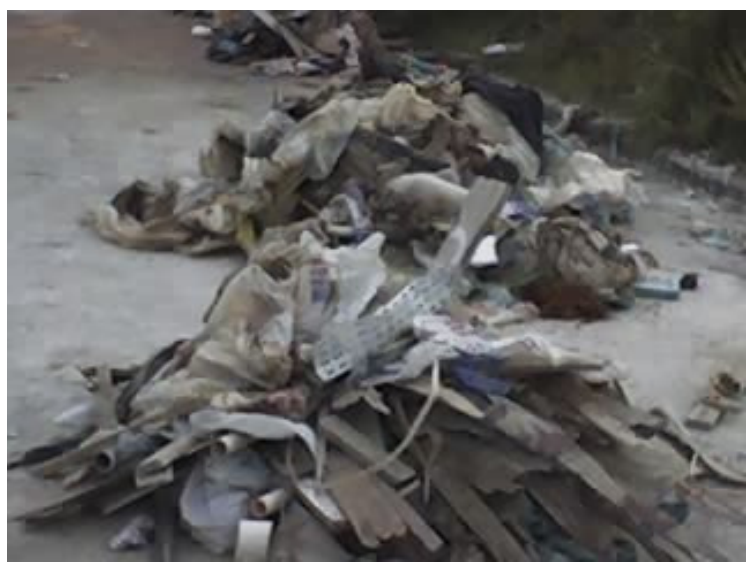

(b)

Figura 4.9 - Redução do tamanho do material no lote, através do martelete pneumático (a), e catação dos materiais indesejáveis (b). 


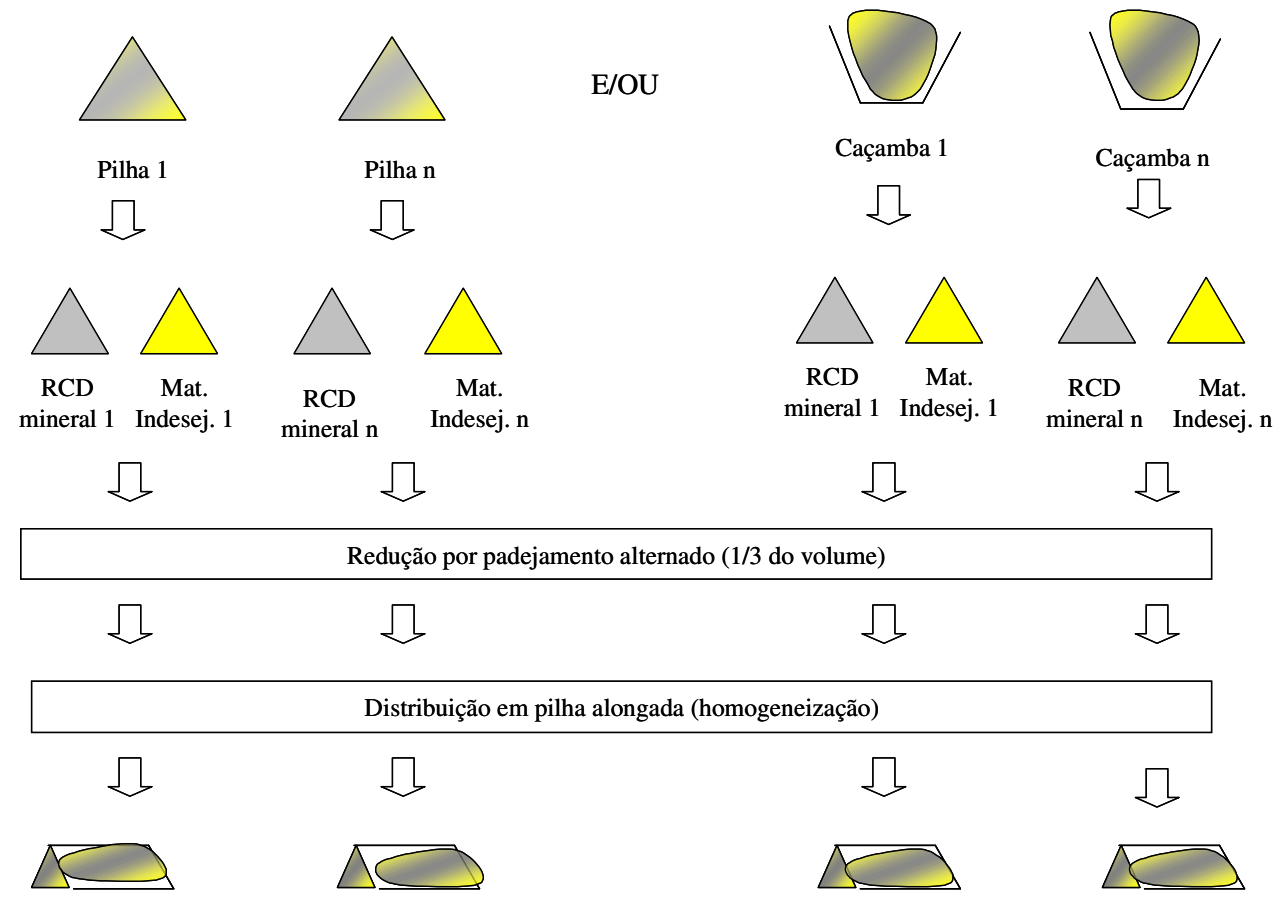

Figura 4.10 - Procedimento de redução do tamanho e homogeneização da amostra.

Os lotes foram reduzidos por padejamento alternado ${ }^{9}$ (Chaves, 1998), empregando a pá de 100L de retroescavadeira (Figura 4.11) e/ou carrinhos de mão, sendo 1/3 do volume $-1,67 \mathrm{~m}^{3}$ - separado para a amostragem.

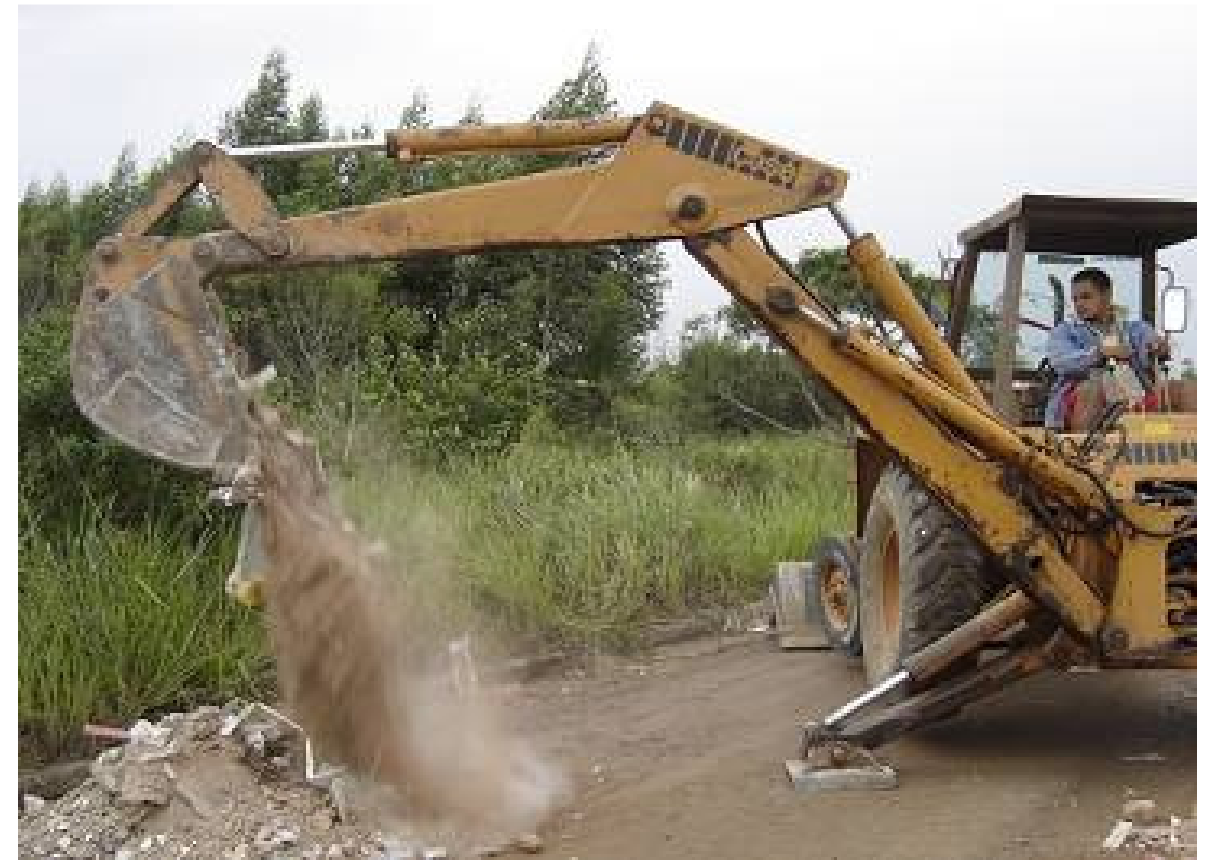

Figura 4.11 - Redução de amostra por padejamento alternado, empregando retroescavadeira.

\footnotetext{
${ }^{9}$ Padejamento alternado é a coleta de parcelas da amostra alternando as extremidades da pilha.
} 
As alíquotas da fração mineral dos lotes de RCD ( $1 / 3$ do volume) foram distribuídas em pilhas alongadas prismáticas, Figura 4.12, como forma de garantir a homogeneização (Petersen, 2004). Diversas camadas foram distribuídas alternando a sua direção. Em seguida, as alíquotas das demais classes dos lotes de RCD (1/3 do volume) foram distribuídas. As extremidades foram tomadas e redistribuídas nas pilhas. O volume (350L, 7 carrinhos de mão) de cada pilha foi coletado como amostra.

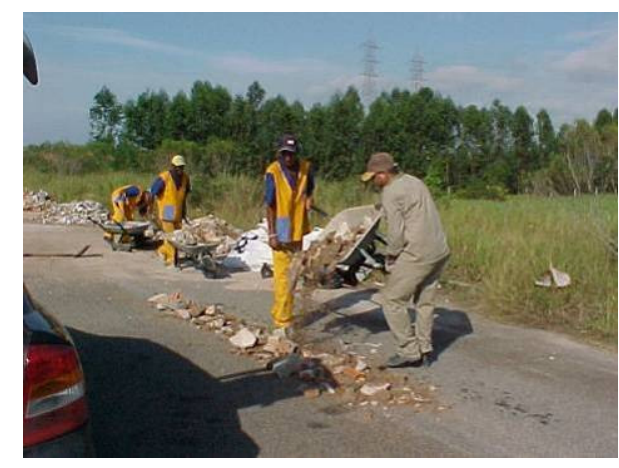

Distribuição da camada da pilha

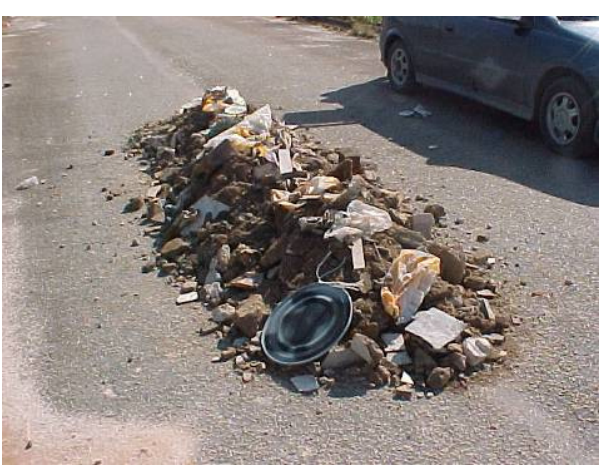

Pilha executada

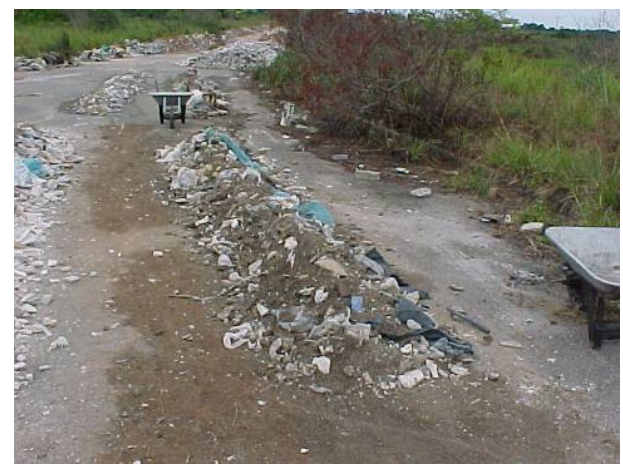

Pilha pronta para coleta da amostra

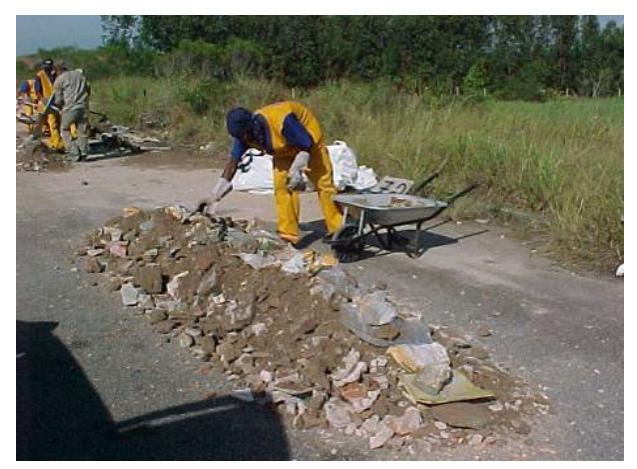

Distribuição das outras classes do RCD

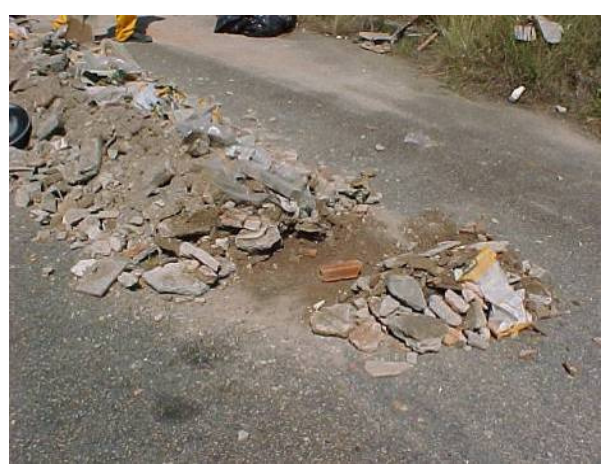

Recorte das extremidades

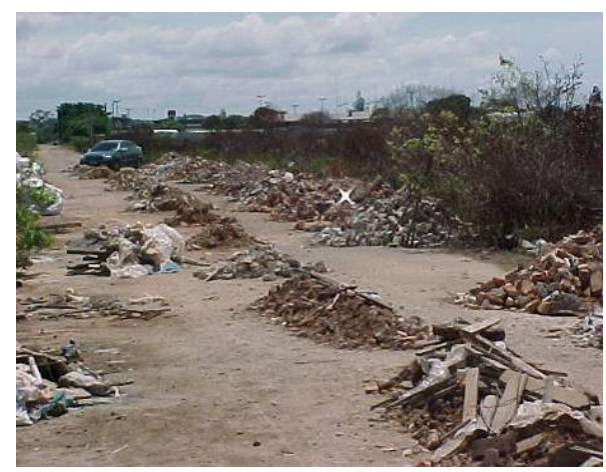

Vista da área de amostragem

Figura 4.12 - Procedimento de formação das pilhas alongadas prismáticas dos lotes de RCD mineral. 
Foram coletadas 51 amostras, que foram armazenadas em bags, num total de 22,5 toneladas. As amostras foram transportadas até o Centro de Tecnologia Mineral (Figura 4.13) para os ensaios previstos na meta física 3 e 4.

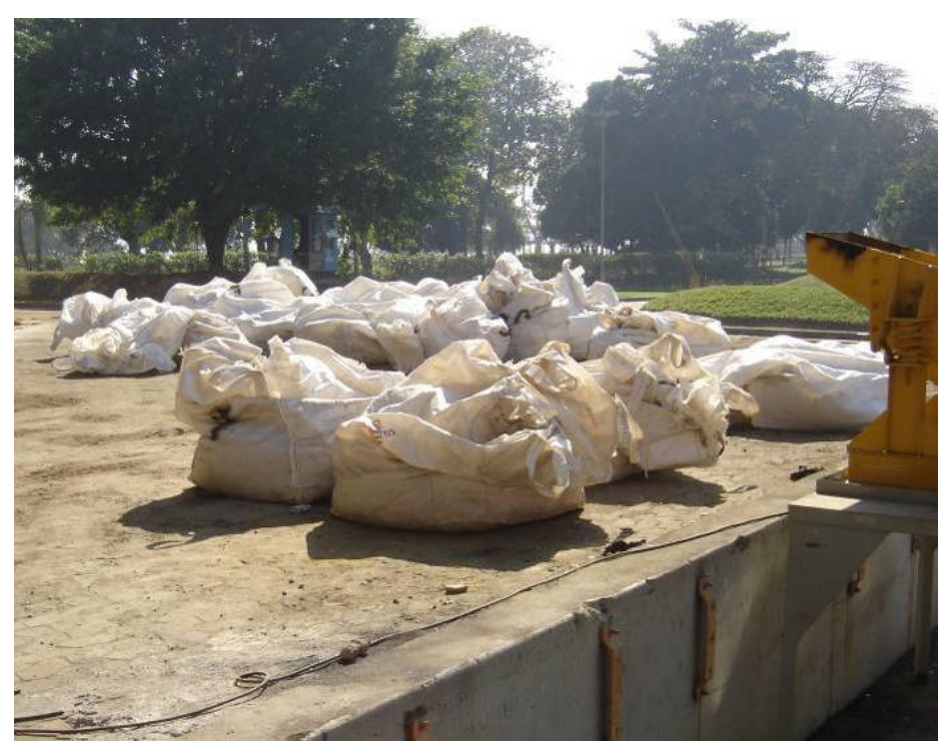

Figura 4.13 - Amostras coletadas de Macaé armazenadas no Centro de Tecnologia Mineral.

\subsection{MUNICÍPIO DE SÃO PAULO}

\subsubsection{Seleção dos locais de amostragem}

Não é tecnicamente viável obter uma amostra representativa para a cidade de São Paulo. Assim, foi selecionada uma área de triagem para o estudo de amostragem, ATT Base Ambiental (Figura 4.14), situada na Rua Alvorada D'Oeste s/n, Jacanã, São Paulo-SP. 


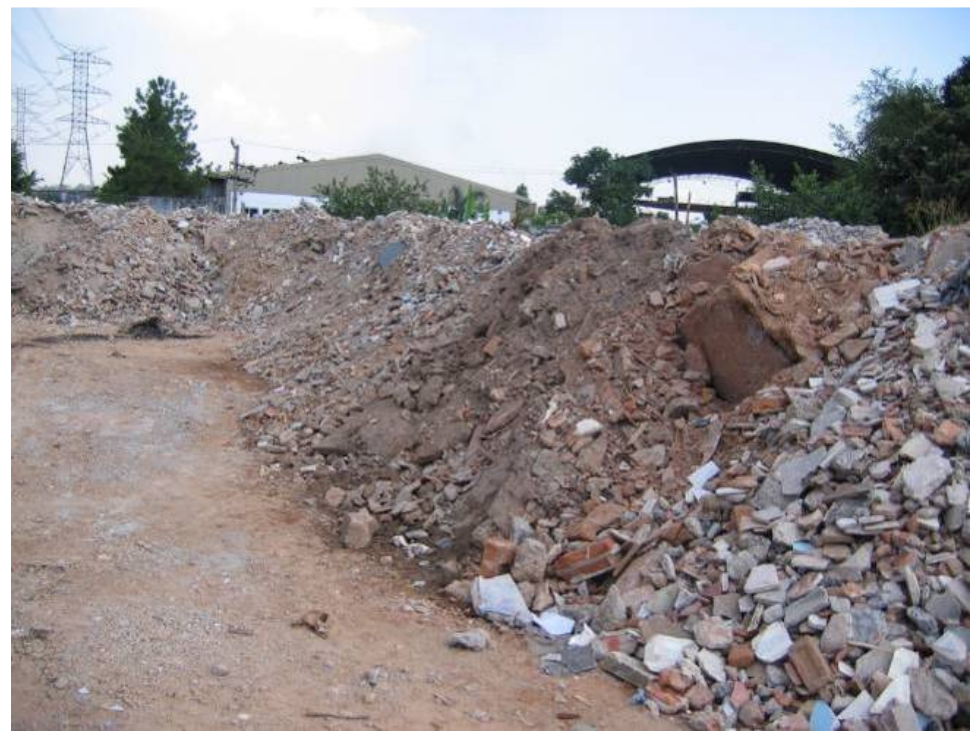

Figura 4.14 - ATT Base Ambiental, na cidade de São Paulo.

$\mathrm{Na}$ entrada da área de triagem, eram recebidas aproximadamente 10 caçambas por dia. No período de 12 a 25 de julho de 2006, aproximadamente 3 caçambas por dia de diferentes localidades (Figura 4.15) foram selecionadas aleatoriamente para a amostragem.

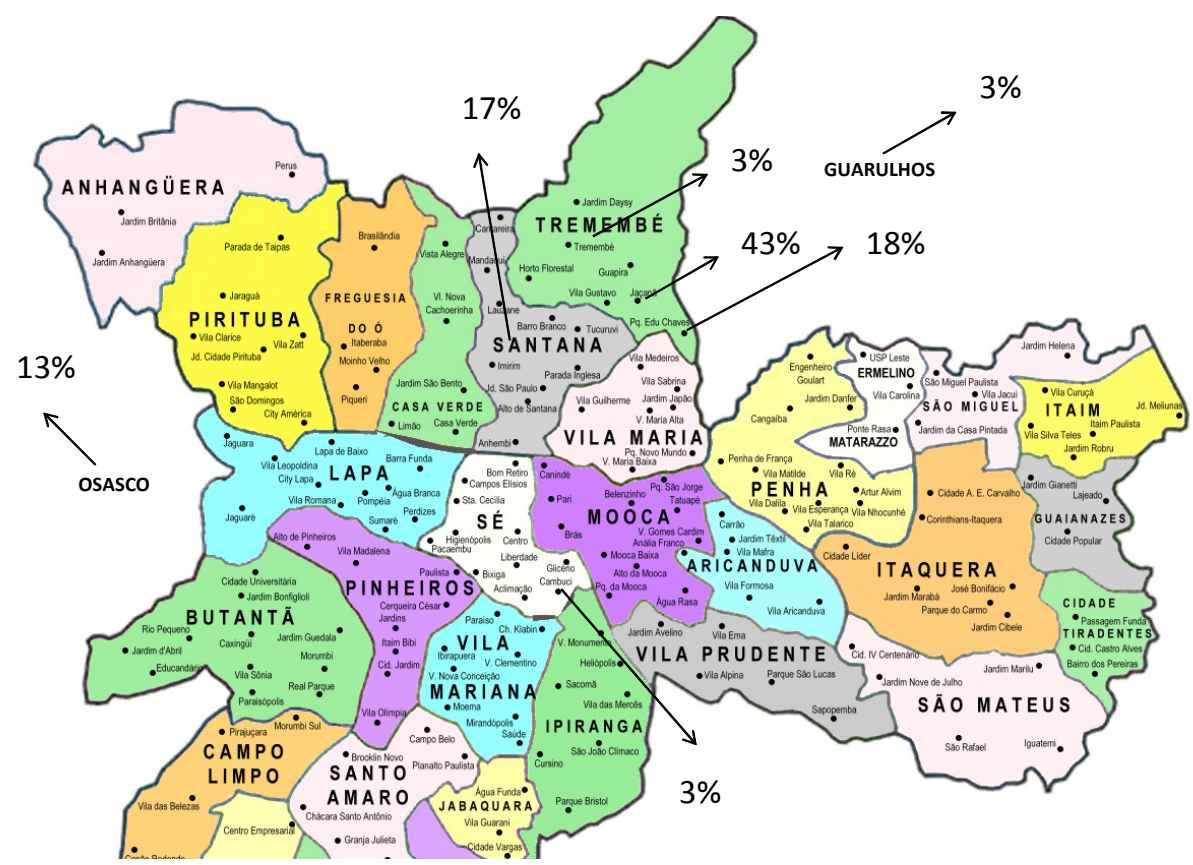

Figura 4.15 - Localidades de coleta de amostras e suas frequências de ocorrências. Os percentuais da origem do RCD foram obtidos através das guias de transporte das caçambas.

\subsubsection{Critério de classificação dos lotes}

Os lotes amostrados foram classificados segundo os seguintes critérios: 
a) Origem: construção ou demolição, de pequeno (construções e reformas residenciais) ou grande porte;

b) Materiais minerais principais: concreto/rocha ou outros materiais;

c) Presença de outros materiais: materiais orgânicos (madeira, plástico, papel), contaminantes (gesso ou cimento amianto) ou solo.

\subsubsection{Redução e preparação das amostras}

A Figura 4.16 ilustra o procedimento de redução e preparação de amostras. Como não havia disponibilidade de uma retroescavadeira, o procedimento empregado para a cidade de Macaé precisou ser adaptado. Assim, o RCD mineral, descarregado da caçamba, era espalhado no chão com o auxílio da pá carregadeira e, depois, com enxada, acertada suas arestas e nivelada a superfície, deixando-o em forma de um paralelepípedo.

Em seguida, a seção era dividida em 54 partes. Uma seção a cada três era removida com o auxílio de pá e carrinho de mão, equivalendo à coleta de aproximadamente $1 / 3$ do volume da caçamba $\left(1,67 \mathrm{~m}^{3}\right)$. Em seguida, pilhas alongadas de 3-4 metros de comprimento foram montadas em camadas sucessivas e alternadas. Devido à baixa concentração de Madeira, não foi necessário dividir a formação da pilha entre os materiais minerais e os materiais orgânicos, conforme realizado na amostragem da cidade de Macaé. As extremidades das pilhas foram tomadas e re-distribuídas. O volume (300L, 6 carrinhos de mão) de cada pilha foi coletado como amostra composta. 

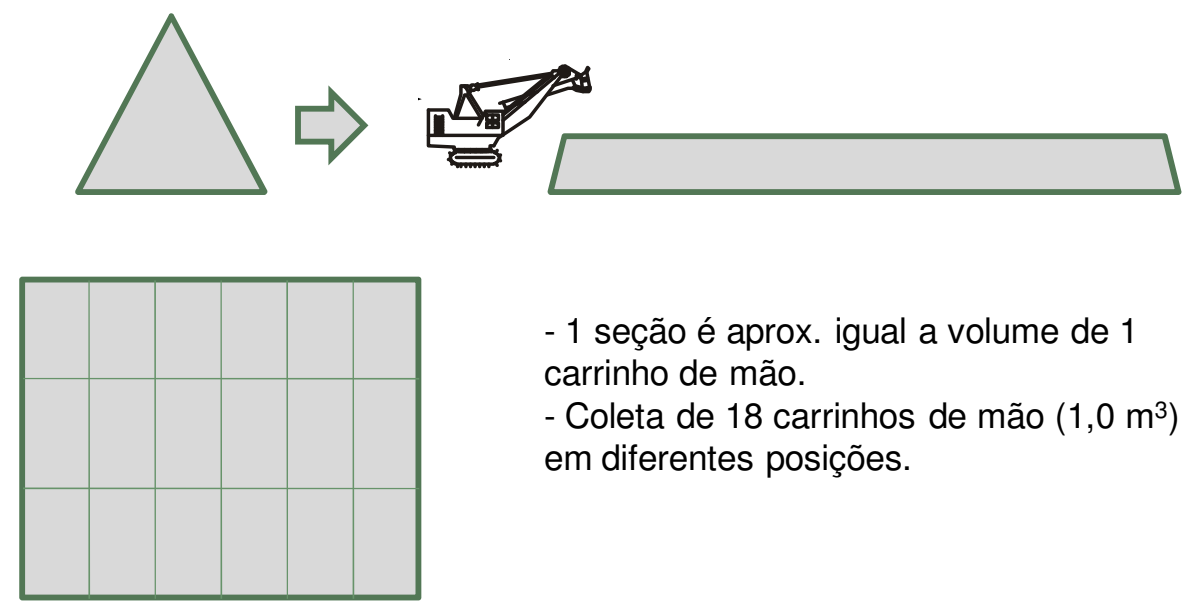

- 1 seção é aprox. igual a volume de 1 carrinho de mão.

- Coleta de 18 carrinhos de mão $\left(1,0 \mathrm{~m}^{3}\right)$ em diferentes posições.

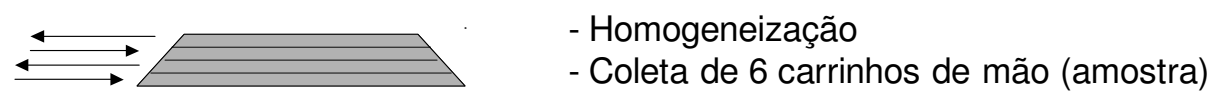

Figura 4.16 - Procedimento de redução e preparação de amostras.

Foram coletadas 52 amostras, que foram armazenadas em bags, num total de 20,3 toneladas. As amostras foram transportadas até o Centro de Tecnologia Mineral.

\subsection{MUNICÍPIO DE MACEIÓ}

\subsubsection{Características da área de estudo}

O Município de Maceió encontra-se no centro da faixa litorânea alagoana, inserida na Mesorregião do Leste, e ocupa uma área de $510,7 \mathrm{~km}^{2}$. Limita-se ao norte com os municípios de Paripueira, São Luis do Quitunde e Fleixeiras; e ao sul com Marechal Deodoro, Coqueiro Seco e Santa Luzia do Norte, onde a lagoa Mundaú ou lagoa do Norte constitui limite natural. O limite de Maceió a leste é o Oceano Atlântico, e a oeste faz fronteira com os municípios de Satuba, Rio Largo e Messias. Os principais acessos a Maceió ocorrem através de estradas pavimentadas (Rodovia AL-101 sul e norte e BR's 104 e 316, esta última também conhecida como Av. Menino Marcelo).

Maceió contava em 2005 com uma população total de 910.978 habitantes e sua densidade demográfica é de $1.784 \mathrm{hab} / \mathrm{km}^{2}$. É objeto desse trabalho apenas a área urbana do município de Maceió, delimitada conforme a Lei Municipal 4.952 de 
06/01/2000. Segundo a Lei Municipal 4.952, atualmente Maceió compreende 50 bairros distribuídos em 7 regiões administrativas.

\subsubsection{Seleção dos locais de amostragem}

Em busca do apoio da Prefeitura do Município de Maceió para a realização desta etapa, foi realizada uma reunião com a mesma abordando os seguintes assuntos: proposta do projeto, definição do apoio da prefeitura na realização desta meta e identificação de órgãos e agentes envolvidos na produção e coleta do RCD. Após a reunião a equipe entrou em contato com as empresas de transporte, cadastradas na prefeitura, que realizavam os transportes de RCD para o depósito da cidade. $\mathrm{Na}$ ocasião apenas duas empesas a Líder e a Limpel faziam esse serviço. Ambas se prontificaram em ajudar o projeto e transportar no período determinado todo RCD tipo classe A para o terreno indicado pela nossa equipe. Foi solicitado pelas mesmas um documento, fornecido por um órgão competente do município, que autorizasse as empresas a depositarem o RCD nesse terreno. $O$ terreno estava localizado na zona norte no litoral da cidade.

Em uma das reuniões com as transportadoras foi explicado o tipo de resíduo, classe A, que deveria ser transportado para o terreno e que não deveria ser de uma única obra ou bairro a fim de aumentar a representatividade das amostras. Para este controle e rastreabilidade das amostras, todos os lotes quando recebidos eram identificados com os seguintes dados:

- Data e hora de chegada dos caminhões ao terreno;

- Empresa transportadora;

- $\quad$ Nome do motorista;

- $\quad$ Origem do material (construção, reforma, demolição, etc.);

- $\quad$ Local de origem (bairro);

- $\quad$ Condição de aceite (se aceito ou não).

Os caminhões transportavam o RCD em cubas estacionárias que variavam de 5 a 6 $\mathrm{m}^{3}$, de forma que no total foram coletados, aproximadamente $256 \mathrm{~m}^{3}$, em dois meses de coleta, abrangendo oito bairros da cidade. 


\subsubsection{Critério de classificação dos lotes}

O terreno para a coleta do RCD foi limpo para que cada caminhão, no total de 49 , pudesse disponibilizar o resíduo em um dos locais individualizados, de modo que o material de cada caminhão foi considerado como um lote, devidamente identificado por um número ordinal.

Após a coleta dos 49 lotes, foram sorteados aleatoriamente 27 lotes para os estudos propostos.

\subsubsection{Redução e preparação das amostras}

A amostragem de alíquotas representativas de cada um dos 27 lotes selecionados foi realizada com uma retroescavadeira segundo o procedimento:

- Coleta de uma alíquota correspondente ao volume de uma pá de retroescavadeira e descarte de duas, de forma que a alíquota amostrada represente $1 / 3$ do volume total da pilha;

- O procedimento foi repetido por todo o comprimento de cada pilha alongada, para os 27 lotes;

- $\quad$ Por fim, as alíquotas foram arquivadas em bags, de forma que a fração total do lote amostrado totalizasse de 6 a 8 carrinhos de mão;

- No total, foram amostradas $16 \mathrm{t}$ de RCD as quais para o CETEM.

\subsection{CLASSIFICAÇÃO DOS LOTES E SUA VARIABILIDADE}

\subsubsection{Macaé}

A Tabela 4.3 e Tabela 4.4 apresentam os resultados da classificação visual dos lotes amostrados na cidade de Macaé. Seguindo o critério de cor para a classificação visual dos lotes, $43 \%$ dos lotes amostrados são vermelhos e $57 \%$ dos lotes são cinza (Figura 4.17a), onde predominam materiais cimentícios. Em apenas 18\% dos lotes amostrados podem ser encontrados o resíduo de concreto visualmente 
homogêneo (Figura 4.17b), sem a mistura com argamassa ou cerâmica vermelha. Isso não corresponde à metade dos lotes classificados como cinza.

Tabela 4.3 - Classificação visual do RCD mineral antigo de Macaé

\begin{tabular}{|c|c|c|c|c|c|}
\hline ID & Foto & $\begin{array}{c}\text { Classificação } \\
\text { visual }\end{array}$ & ID & Foto & $\begin{array}{c}\text { Classificação } \\
\text { visual }\end{array}$ \\
\hline $2-1$ & & $\begin{array}{l}\text { Vermelho. } \\
\text { Cer. Vermelha } \\
\text { + Argamassa. } \\
\text { Madeira. }\end{array}$ & 50-1 & & $\begin{array}{l}\text { Cinza. } \\
\text { Concreto. } \\
\text { Plástico. }\end{array}$ \\
\hline 3-1 & & $\begin{array}{l}\text { Cinza. } \\
\text { Concreto. } \\
\text { Gesso. }\end{array}$ & $51-1$ & & $\begin{array}{l}\text { Cinza. } \\
\text { Concreto. } \\
\text { Solo. }\end{array}$ \\
\hline $5-1$ & & $\begin{array}{l}\text { Cinza. } \\
\text { Cer. Vermelha } \\
\text { + Argamassa. } \\
\text { Plástico. }\end{array}$ & 54-1 & & $\begin{array}{l}\text { Vermelho. } \\
\text { Cer. Vermelha } \\
\text { + Argamassa. } \\
\text { Plástico. }\end{array}$ \\
\hline $9-1$ & & $\begin{array}{l}\text { Vermelho. } \\
\text { Cer. Vermelha } \\
+ \text { Argamassa. } \\
\text { Madeira. }\end{array}$ & $57-1$ & & $\begin{array}{l}\text { Vermelho. } \\
\text { Cer. Vermelha } \\
+ \text { Argamassa. } \\
\text { Madeira. }\end{array}$ \\
\hline $15-1$ & & $\begin{array}{l}\text { Cinza. } \\
\text { Cer. Vermelha } \\
\text { + Concreto. } \\
\text { Madeira. }\end{array}$ & $58-1$ & & $\begin{array}{l}\text { Vermelho. } \\
\text { Cer. Vermelha } \\
\text { + Argamassa. } \\
\text { Solo. }\end{array}$ \\
\hline
\end{tabular}

Continua

Continuação.

\begin{tabular}{|c|c|c|c|c|}
\hline $20-1$ & $\begin{array}{l}\text { Vermelho. } \\
\text { Cer. Vermelha } \\
\text { + Argamassa. } \\
\text { Madeira. }\end{array}$ & $61-1$ & si & $\begin{array}{l}\text { Cinza. } \\
\text { Cer. Vermelha } \\
\text { + Cer. Branca } \\
\text { Cim. Amianto. }\end{array}$ \\
\hline $26-1$ & $\begin{array}{l}\text { Cinza. } \\
\text { Concreto } \\
\text { estrutural. } \\
\text { Solo. }\end{array}$ & 63-1 & 2 & $\begin{array}{l}\text { Vermelho. } \\
\text { Cer. Vermelha } \\
\text { + Concreto. } \\
\text { Aço. }\end{array}$ \\
\hline
\end{tabular}




\begin{tabular}{|c|c|c|c|}
\hline $30-1$ & $\begin{array}{l}\text { Cinza. } \\
\text { Concreto } \\
\text { estrutural. } \\
\text { Solo. }\end{array}$ & $65-1$ & $\begin{array}{l}\text { Cinza. } \\
\text { Cer. Vermelha } \\
\text { + Concreto. } \\
\text { Aço. }\end{array}$ \\
\hline $33-1$ & $\begin{array}{l}\text { Cinza. } \\
\text { Concreto } \\
\text { estrutural. } \\
\text { Solo. }\end{array}$ & $67-1$ & $\begin{array}{l}\text { Cinza. } \\
\text { Concreto + } \\
\text { Argamassa. } \\
\text { Madeira. }\end{array}$ \\
\hline $40-1$ & $\begin{array}{l}\text { Cinza. } \\
\text { Argamassa. } \\
\text { Plástico. }\end{array}$ & $69-1$ & $\begin{array}{l}\text { Cinza. } \\
\text { Cer. Vermelha } \\
\text { + Concreto. } \\
\text { Solo. }\end{array}$ \\
\hline 41-1 & $\begin{array}{l}\text { Cinza. } \\
\text { Argamassa. } \\
\text { Gesso. }\end{array}$ & $72-1$ & $\begin{array}{l}\text { Vermelho. } \\
\text { Rocha+ } \\
\text { Cerâmica } \\
\text { vermelha. } \\
\text { Madeira. }\end{array}$ \\
\hline $42-1$ & $\begin{array}{l}\text { Cinza. } \\
\text { Argamassa. } \\
\text { Gesso. }\end{array}$ & $80-1$ & $\begin{array}{l}\text { Vermelho. } \\
\text { Cerâmica } \\
\text { Vermelha + } \\
\text { Argamassa. } \\
\text { Madeira. }\end{array}$ \\
\hline $46-1$ & $\begin{array}{l}\text { Cinza. } \\
\text { Concreto. } \\
\text { Plástico. }\end{array}$ & $84-1$ & $\begin{array}{l}\text { Cinza. } \\
\text { Cerâmica } \\
\text { Vermelha. } \\
\text { Cim. Amianto. }\end{array}$ \\
\hline $49-1$ & $\begin{array}{l}\text { Cinza. } \\
\text { Argamassa. } \\
\text { Gesso. }\end{array}$ & & \\
\hline
\end{tabular}

Tabela 4.4 - Classificação visual do RCD mineral antigo de Macaé

\begin{tabular}{|c|c|c|c|c|c|}
\hline ID & Foto & $\begin{array}{c}\text { Classificação } \\
\text { visual }\end{array}$ & ID & Foto & $\begin{array}{c}\text { Classificação } \\
\text { visual }\end{array}$ \\
\hline $1-2$ & & $\begin{array}{l}\text { Cinza. } \\
\text { Cer. Vermelha } \\
\text { + Argamassa. } \\
\text { Plástico. }\end{array}$ & $19-2$ & & $\begin{array}{l}\text { rmelho. } \\
\text { gamassa. } \\
\text { ástico. }\end{array}$ \\
\hline
\end{tabular}




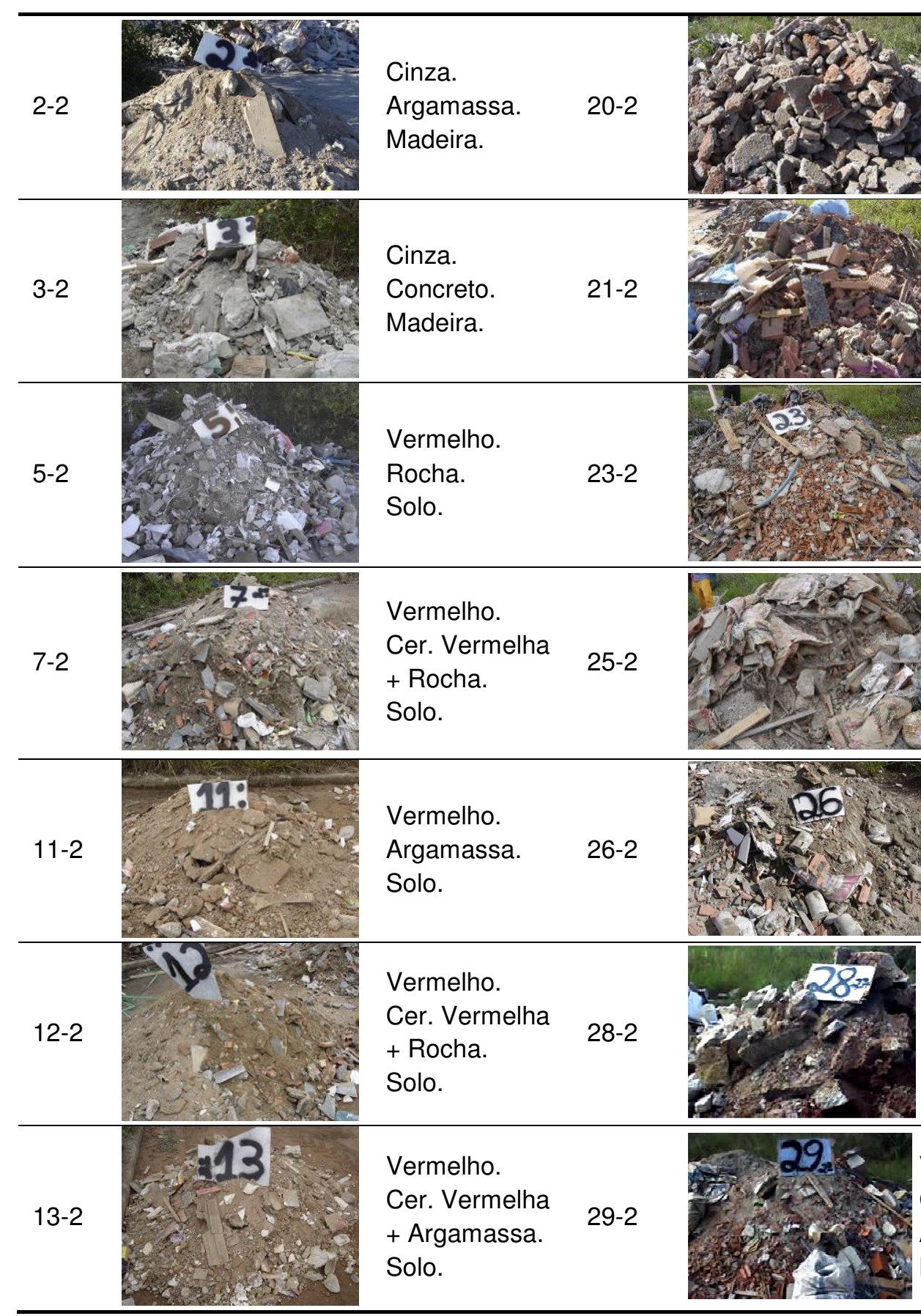

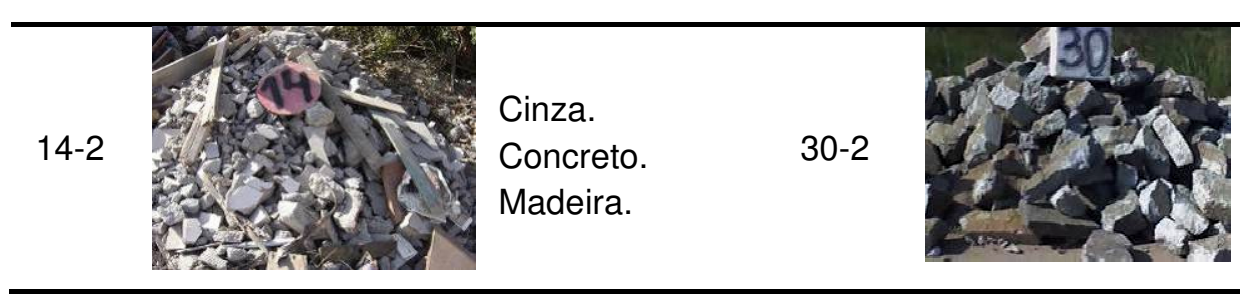




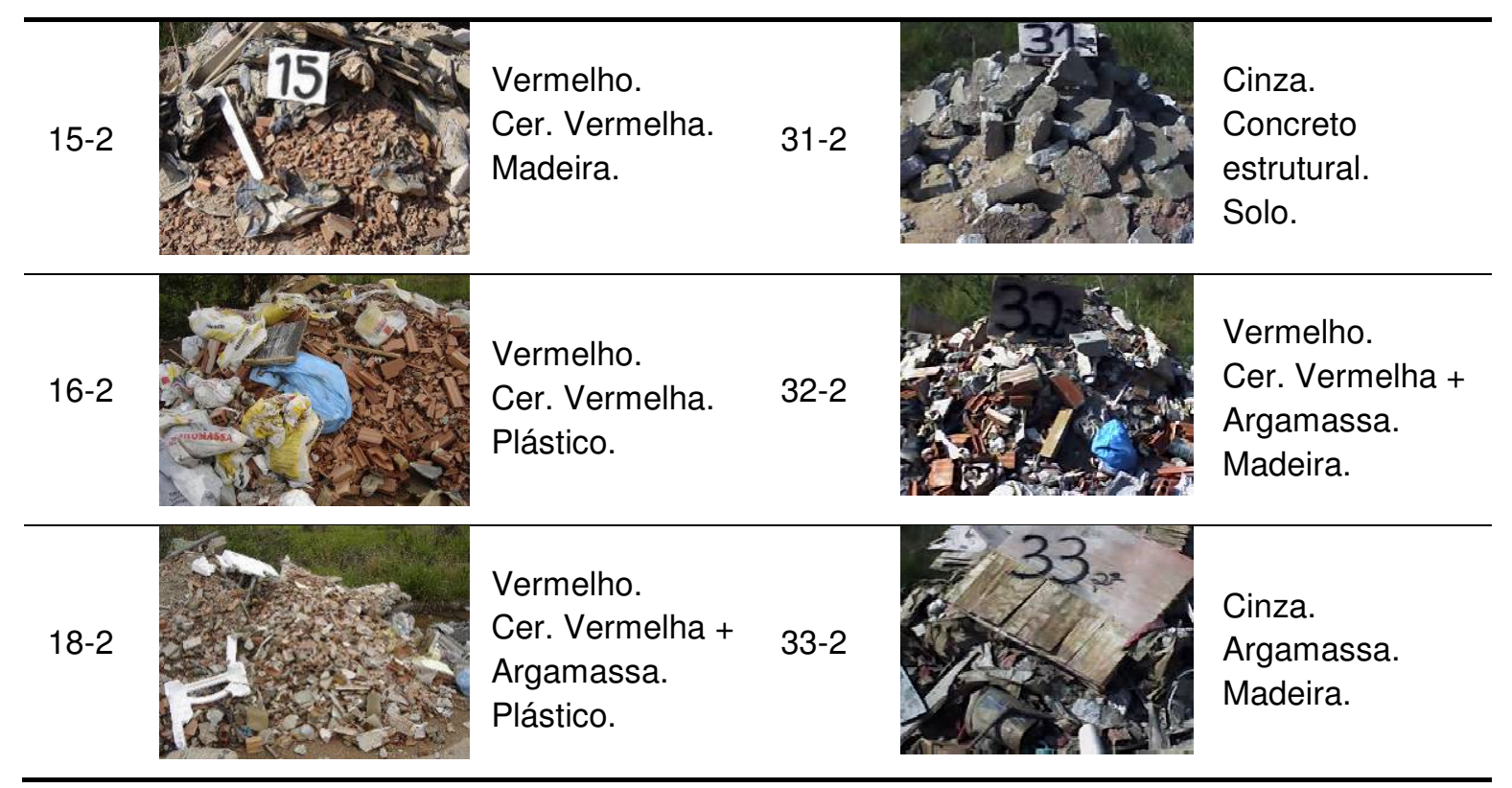

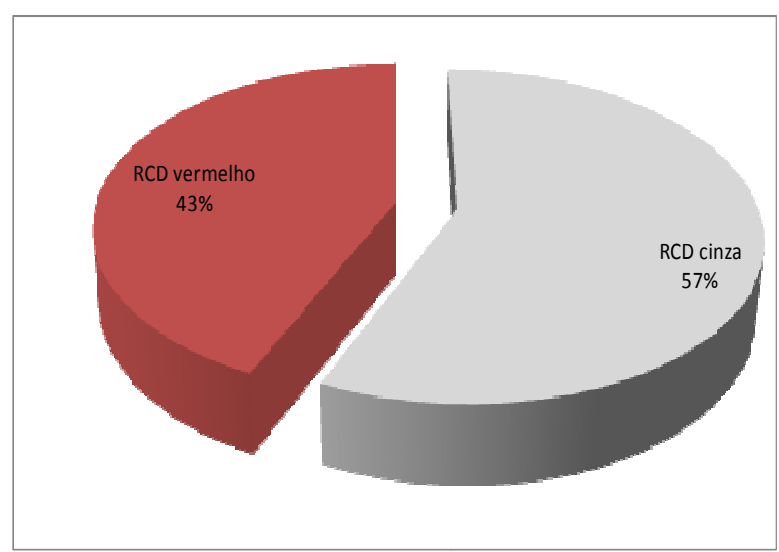

(a)

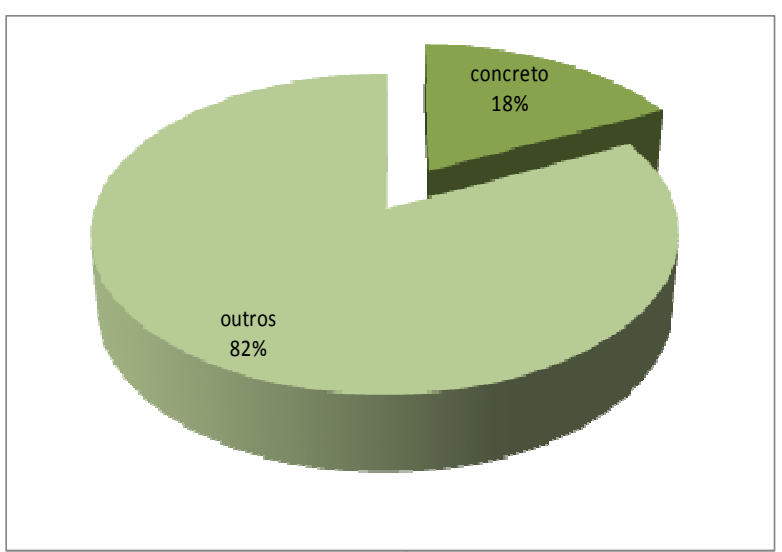

(b)

Figura 4.17 - Síntese da classificação visual dos lotes de Macaé: a) cinza e vermelho e b) concreto.

Em 98\% dos lotes analisados foi observada a presença de materiais indesejáveis ou contaminantes. Em torno de $55 \%$ dos lotes indicam visualmente a presença de materiais orgânicos leves (madeira, plástico ou papel). Deste total, a grande maioria (31\%) dos materiais orgânicos leves é a madeira. A mistura com solo é também representativa, em torno de $27 \%$ do total dos lotes.

Quanto à mistura com resíduos perigosos ou contaminantes no processo de reciclagem (cimento amianto e gesso), de acordo com a resolução 307 do Conselho Nacional do Meio Ambiente (CONAMA), apenas em 4\% dos lotes amostrados foi identificada a presença de cimento amianto. A presença de gesso foi observada em $8 \%$ dos lotes amostrados (Figura 4.18). 


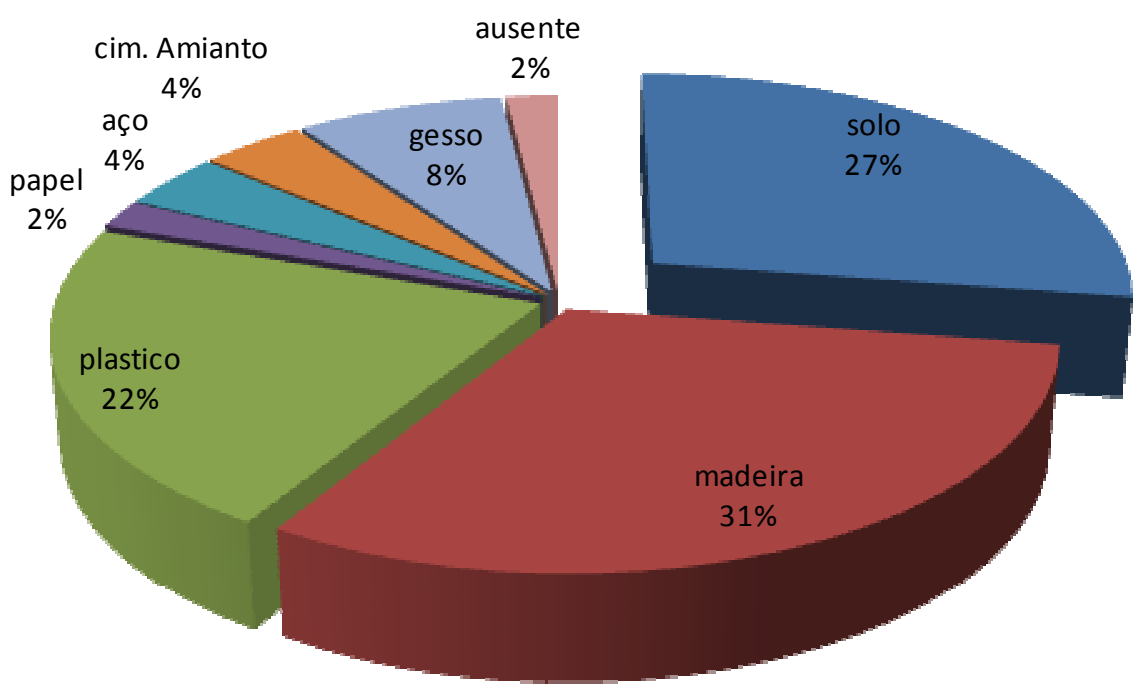

Figura 4.18 - Presença de materiais indesejáveis e contaminantes nos lotes de RCD mineral de Macaé.

\subsubsection{São Paulo}

A Tabela 4.5 apresenta os resultados da classificação visual e da origem dos lotes na cidade de São Paulo. $81 \%$ das amostras foram originadas da região do Tremembé e Santana, zona norte da cidade. O restante das amostras provém de regiões como Guarulhos, Osasco e Sé. A Figura 4.19a mostra a frequência dos critérios definidos para classificar a origem do RCD mineral. Foi possível identificar a origem de cerca de $50 \%$ dos lotes amostrados. Mais da metade é originada de demolições e reformas residenciais, seguido de demolições executadas em empresas privadas, escolas ou locais públicos. O resíduo de construção originado de construtoras e fabricantes de materiais de construção (marmorarias etc) não foi representativo nessa região. Diferentemente das amostras da cidade de Macaé, a presença de resíduo homogêneo de concreto ou rocha é mais frequente (Figura $4.19 b)$, cerca de $44 \%$.

Tabela 4.5 - Classificação visual e da origem dos lotes da cidade de São Paulo.

\begin{tabular}{llllll}
\hline ID & Local & Origem & ID & Local & Origem \\
\hline \multirow{2}{*}{1} & - & Construção (grande gerador). & 27 & $\begin{array}{l}\text { Z. N. } \\
\text { Tremembé }\end{array}$ & $\begin{array}{l}\text { Rocha. } \\
\text { Asfalto. }\end{array}$ \\
\hline \multirow{2}{*}{2} & \multirow{2}{*}{ Osasco } & $\begin{array}{l}\text { Concreto. } \\
\text { Outrução (grande gerador). }\end{array}$ & 28 & - & \begin{tabular}{l} 
Concreto. \\
\hline
\end{tabular} \\
\hline
\end{tabular}




\begin{tabular}{|c|c|c|c|c|c|}
\hline & & Solo. & & & Gesso. \\
\hline 3 & Osasco & $\begin{array}{l}\text { Demolição (pequeno gerador). } \\
\text { Outros materiais minerais. }\end{array}$ & 29 & - & - \\
\hline 4 & $\begin{array}{l}\text { Z. N. } \\
\text { Tremembé }\end{array}$ & $\begin{array}{l}\text { Demolição (grande gerador). } \\
\text { Concreto. }\end{array}$ & 30 & $\begin{array}{l}\text { Centro } \\
\text { Sé }\end{array}$ & $\begin{array}{l}\text { - } \\
\text { Argamassa. } \\
\text { Solo. }\end{array}$ \\
\hline 5 & $\begin{array}{l}\text { Z. N. } \\
\text { Tremembé }\end{array}$ & $\begin{array}{l}\text { Demolição (pequeno gerador). } \\
\text { Outros materiais minerais. }\end{array}$ & 31 & $\begin{array}{l}\text { Z. N. } \\
\text { Tremembé }\end{array}$ & $\begin{array}{l}\text { Demolição (pequeno } \\
\text { gerador). }\end{array}$ \\
\hline 6 & $\begin{array}{l}\text { Z. N. } \\
\text { Santana }\end{array}$ & $\begin{array}{l}\text { Demolição (grande gerador). } \\
\text { Concreto. }\end{array}$ & 32 & $\begin{array}{l}\text { Z. N. } \\
\text { Santana }\end{array}$ & $\begin{array}{l}\text { Demolição (grande } \\
\text { gerador). } \\
\text { Concreto. }\end{array}$ \\
\hline 7 & $\begin{array}{l}\text { Z. N. } \\
\text { Tremembé }\end{array}$ & $\begin{array}{l}\text { Demolição (pequeno gerador). } \\
\text { Concreto. }\end{array}$ & 33 & $\begin{array}{l}\text { Z. N. } \\
\text { Santana }\end{array}$ & $\begin{array}{l}\text { Demolição (grande } \\
\text { gerador). } \\
\text { Concreto. }\end{array}$ \\
\hline 8 & $\begin{array}{l}\text { Z. N. } \\
\text { Tremembé }\end{array}$ & $\begin{array}{l}\text { Construção. } \\
\text { Outros materiais minerais. } \\
\text { Madeira. }\end{array}$ & 34 & - & Rocha. \\
\hline 9 & $\begin{array}{l}\text { Z. N. } \\
\text { Tremembé }\end{array}$ & $\begin{array}{l}\text { Demolição (pequeno gerador). } \\
\text { Outros materiais minerais. } \\
\text { Solo. }\end{array}$ & 35 & - & - \\
\hline 10 & $\begin{array}{l}\text { Z. N. } \\
\text { Santana }\end{array}$ & $\begin{array}{l}\text { - } \\
\text { Mutros materiais minerais. } \\
\text { Madeira. }\end{array}$ & 36 & $\begin{array}{l}\text { Z. N. } \\
\text { Tremembé }\end{array}$ & $\begin{array}{l}\text { Demolição (grande } \\
\text { gerador). } \\
\text { Concreto. } \\
\text { Solo. }\end{array}$ \\
\hline 11 & - & $\begin{array}{l}\text { Construção (grande gerador). } \\
\text { Rochas. }\end{array}$ & 37 & $\begin{array}{l}\text { Z. N. } \\
\text { Tremembé }\end{array}$ & $\begin{array}{l}\text { Demolição (grande } \\
\text { gerador). } \\
\text { Concreto. } \\
\text { Solo. }\end{array}$ \\
\hline 12 & Osasco & $\begin{array}{l}\text { Demolição (pequeno gerador). } \\
\text { Outros materiais minerais. }\end{array}$ & 38 & - & $\begin{array}{l}\text { - } \\
\text { Outros materiais minerais. } \\
\text { Gesso. }\end{array}$ \\
\hline 13 & - & $\begin{array}{l}\text { Demolição (pequeno gerador). } \\
\text { Outros materiais minerais. }\end{array}$ & 39 & - & $\begin{array}{l}\text { - } \\
\text { Outros materiais minerais. } \\
\text { Solo. }\end{array}$ \\
\hline 14 & - & $\begin{array}{l}\text { Demolição (grande gerador). } \\
\text { Concreto. }\end{array}$ & 40 & - & $\begin{array}{l}\text { - } \\
\text { Outros materiais minerais. } \\
\text { Solo. }\end{array}$ \\
\hline 15 & - & $\begin{array}{l}\text { Demolição (pequeno gerador). } \\
\text { Outros materiais minerais. }\end{array}$ & 41 & - & - \\
\hline
\end{tabular}

Continuação

\begin{tabular}{lllll}
\hline \multirow{2}{*}{-} & $\begin{array}{l}\text { Demolição (pequeno gerador). } \\
\text { Outros materiais minerais. } \\
\text { Gesso. }\end{array}$ & $42-$ & $\begin{array}{l}\text { Outros materiais minerais. } \\
\text { Solo. }\end{array}$ \\
\hline $17 \quad-$ & $\begin{array}{l}\text { Demolição. } \\
\text { Concreto. }\end{array}$ & 43 & Guarulhos & $\begin{array}{l}- \\
\text { Concreto. }\end{array}$ \\
\hline 18 Z. N. & Demolição (pequeno gerador). & 44 & Z. N. & Demolição (pequeno \\
\hline
\end{tabular}




\begin{tabular}{|c|c|c|c|c|c|}
\hline & Tremembé & Outros materiais minerais. & & Tremembé & $\begin{array}{l}\text { gerador). } \\
\text { Outros materiais minerais. }\end{array}$ \\
\hline 19 & $\begin{array}{l}\text { Z. N. } \\
\text { Santana }\end{array}$ & $\begin{array}{l}\text { Demolição (pequeno gerador). } \\
\text { Concreto/rocha. }\end{array}$ & 45 & - & - \\
\hline 20 & $\begin{array}{l}\text { Z. N. } \\
\text { Tremembé }\end{array}$ & $\begin{array}{l}\text { - } \\
\text { Concreto. } \\
\text { Cimento amianto. }\end{array}$ & 46 & $\begin{array}{l}\text { Z. N. } \\
\text { Tremembé }\end{array}$ & $\begin{array}{l}\text { - } \\
\text { Outros materiais minerais. } \\
\text { Solo. }\end{array}$ \\
\hline 21 & $\begin{array}{l}\text { Z. N. } \\
\text { Tremembé }\end{array}$ & $\begin{array}{l}\text { Demolição (pequeno gerador). } \\
\text { Outros materiais minerais. }\end{array}$ & 47 & - & $\begin{array}{l}\text { - } \\
\text { Concreto. } \\
\text { Solo. }\end{array}$ \\
\hline 22 & - & $\begin{array}{l}\text { Demolição (grande gerador). } \\
\text { Rocha. }\end{array}$ & 48 & $\begin{array}{l}\text { Z. N. } \\
\text { Tremembé }\end{array}$ & $\begin{array}{l}\text { - } \\
\text { Outros materiais minerais. } \\
\text { Solo. }\end{array}$ \\
\hline 23 & - & $\begin{array}{l}\text { Demolição (pequeno gerador). } \\
\text { Outros materiais minerais. } \\
\text { Solo. }\end{array}$ & 49 & $\begin{array}{l}\text { Z. N. } \\
\text { Tremembé }\end{array}$ & $\begin{array}{l}\text { Demolição (grande gerador) } \\
\text { Outros materiais minerais. }\end{array}$ \\
\hline 24 & - & - & 50 & - & $\begin{array}{l}\text { Construção } \\
\text { Outros materiais minerais. } \\
\text { Madeira. }\end{array}$ \\
\hline 25 & $\begin{array}{l}\text { Z. N. } \\
\text { Tremembé }\end{array}$ & $\begin{array}{l}\text { Construção (grande gerador). } \\
\text { Rocha. }\end{array}$ & 51 & $\begin{array}{l}\text { Z. N. } \\
\text { Tremembé }\end{array}$ & - \\
\hline 26 & Osasco & $\begin{array}{l}\text { - } \\
\text { Outros materiais minerais. } \\
\text { Solo. }\end{array}$ & 52 & $\begin{array}{l}\text { Z. N. } \\
\text { Tremembé }\end{array}$ & $\begin{array}{l}\text { Demolição (grande gerador) } \\
\text { Concreto. }\end{array}$ \\
\hline
\end{tabular}

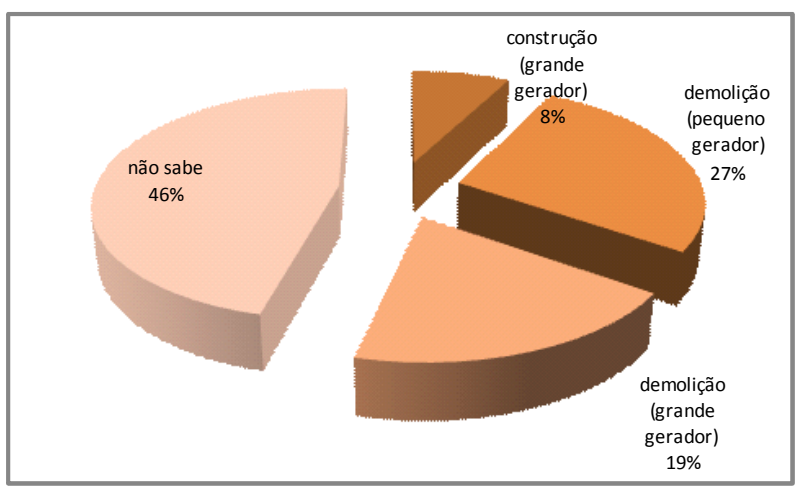

(a)

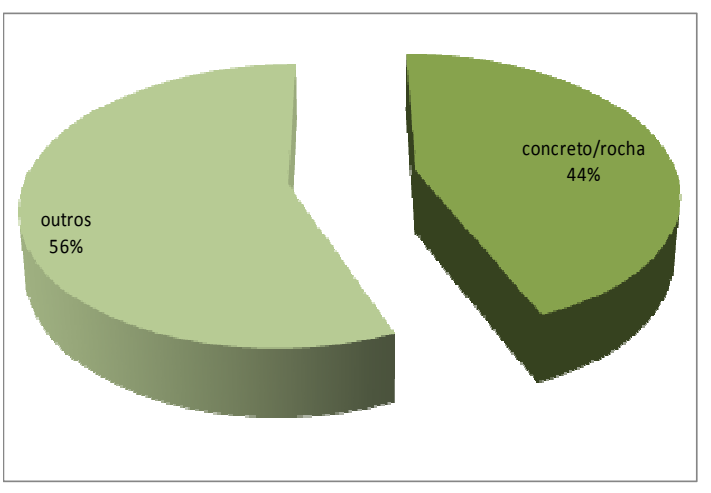

(b)

Figura 4.19 - Amostras do RCD mineral de São Paulo: (a) origem (frequência); (b) presença de concreto/rocha.

Em São Paulo não foram observados contaminantes e materiais indesejáveis para o processo de reciclagem em 59\% das amostras. Nas amostras que apresentaram certo grau de contaminação (41\%), a mistura do RCD com solo é mais frequente e semelhante a observada na cidade de Macaé, presente em cerca de $25 \%$ do total de amostras. A presença de madeira não foi tão expressiva quanto para a cidade de 
Macaé, presente em apenas $6 \%$ do total de amostras. A contaminação do RCD mineral por gesso $(6 \%)$ e por cimento amianto $(2 \%)$ nas amostras de São Paulo foi semelhante à observada nas amostras de Macaé ( $8 \%$ e $4 \%$, respectivamente). Foi observada a presença de asfalto numa das amostras.

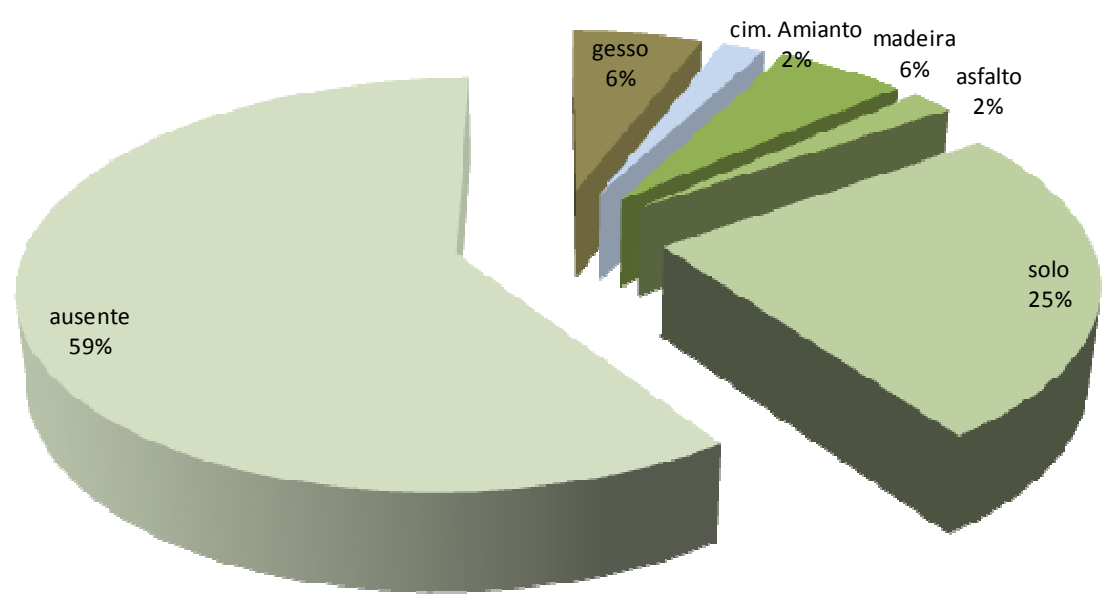

Figura 4.20 - Presença de materiais indesejáveis e contaminantes nos lotes de RCD mineral de São Paulo.

\subsubsection{Maceió}

Para a cidade de Maceió não foi realizado uma inspeção visual mais detalhada para o estudo de contaminantes e materiais indesejáveis.

\subsubsection{0 balanço de massa dos materiais indesejáveis e a separação visual do RCD em classes}

Com base na caracterização granulométrica (de 20 a 50 caçambas de cada cidade), Figura 4.21, pode-se concluir que o RCD das três cidades tem:

a) $55 \%$, na média, da sua massa com granulometria abaixo de $63 \mathrm{~mm}$ (Figura 4.21), viabilizando o emprego direto do material como brita graduada reciclada, sem a necessidade de um britador;

b) $35 \%$, na média, da sua massa com granulometria abaixo de $25,4 \mathrm{~mm}$, justificando sistema de escalpe, com o intuito de aumentar a capacidade de operação do britador. 


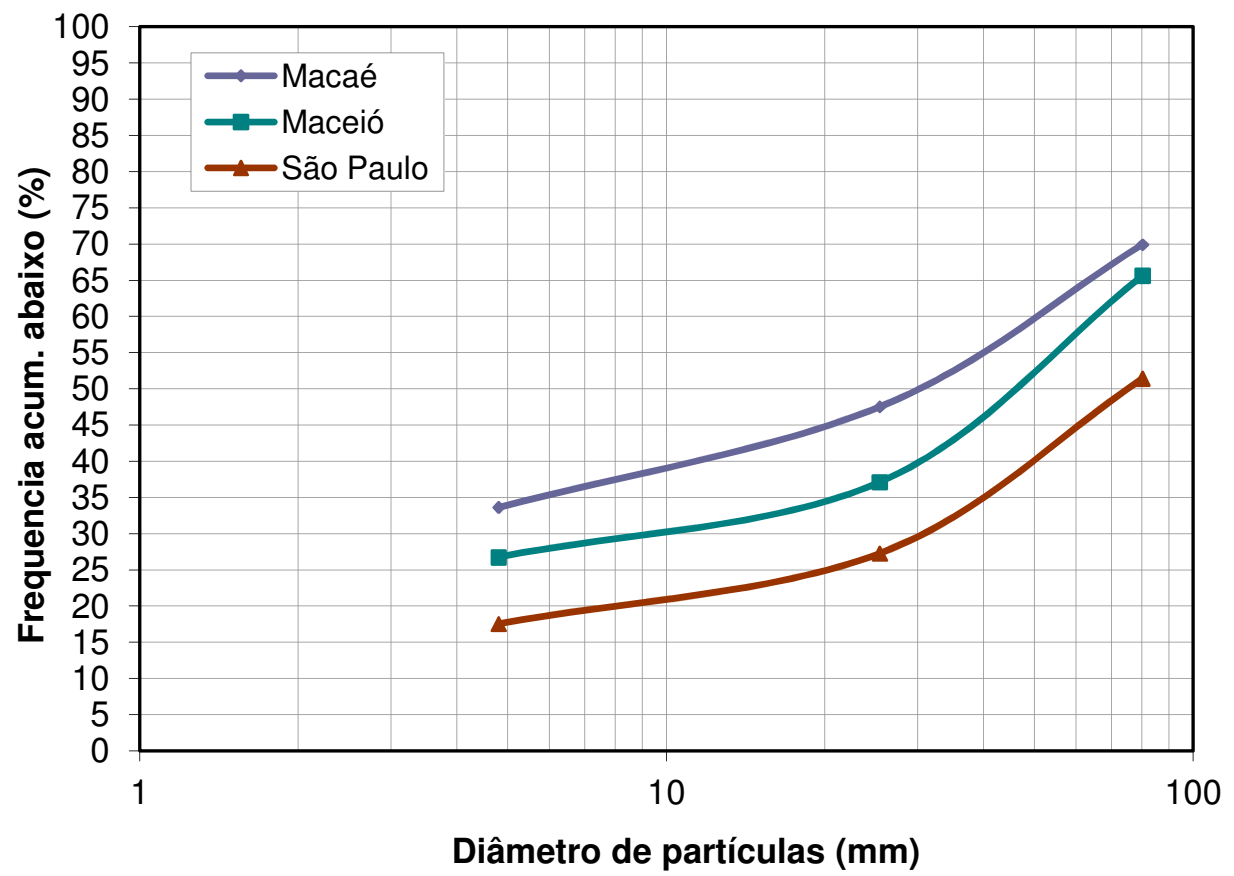

Figura 4.21 - Distribuição granulométrica do RCD para diversas caçambas

Com base na caracterização da composição (Figura 4.22), ficou evidenciado que:

a) Em torno de $50 \%$ da massa do RCD pode conter teores excessivos de materiais indesejáveis (principalmente a madeira) e contaminantes (gesso e cimento amianto), como no caso das amostragens em Macaé e São Paulo;

b) $\mathrm{O} R \mathrm{CD}$, classificado visualmente como RCD mineral (concreto, argamassas, cerâmicas e outros) pode atingir alto grau de pureza para os materiais indesejáveis, mas não para contaminantes como o gesso, tornando a operação de catação algo fundamental para se atingir um agregado reciclado de qualidade aceitável. 


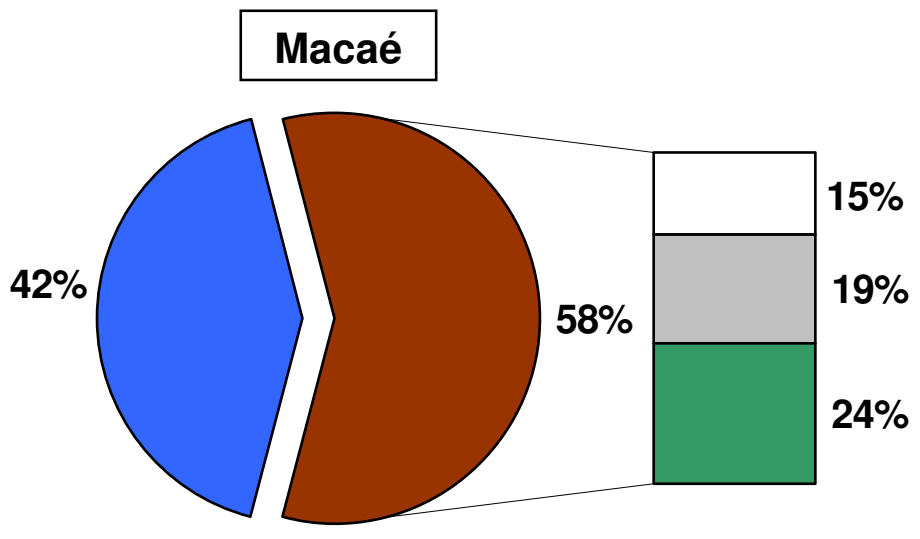

$\square$ Sem contaminantes $\square$ Gesso $>1 \% \quad \square$ Amianto >0,1\% $\square$ Orgânicos >3\%

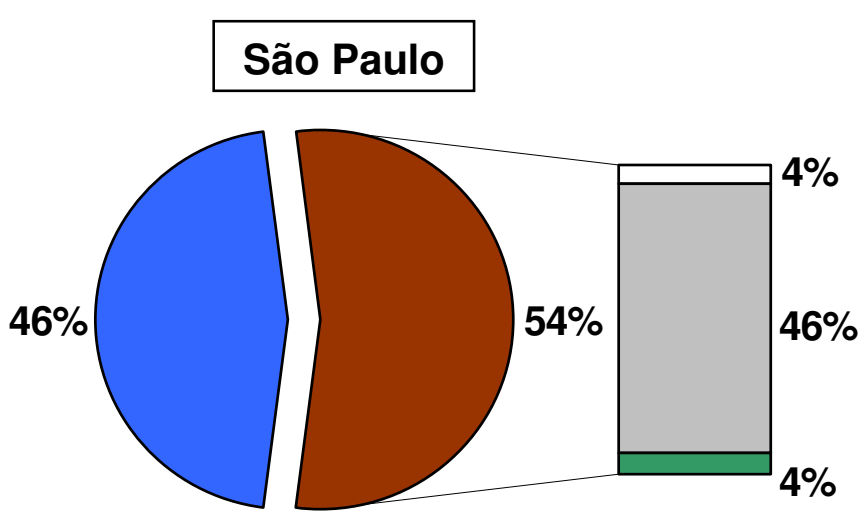

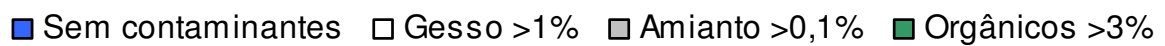

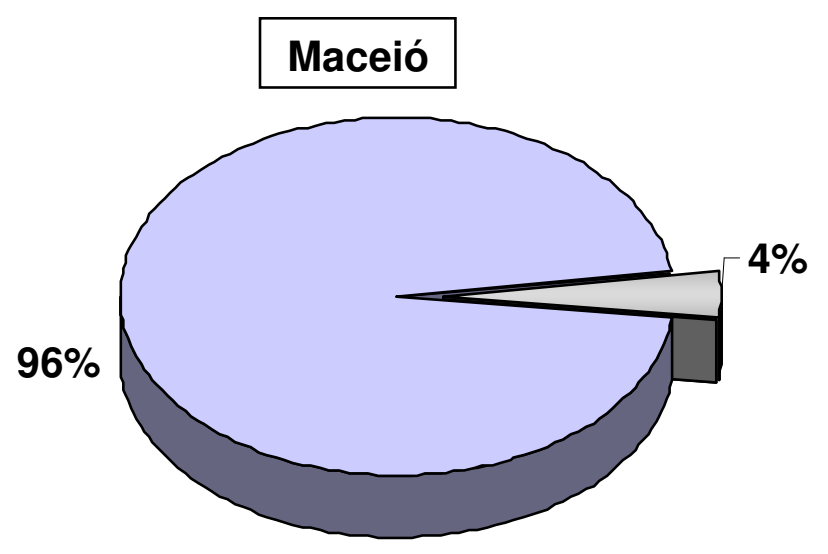

$\square$ Sem contaminantes $\quad \square$ Gesso $>1 \%$

Figura 4.22 - Esquema da caracterização da composição para as três cidades 


\subsection{CARACTERIZAÇÃO DOS RCD E AGREGADOS REGIONAIS}

Todos os lotes de RCD amostrados, total de 131 (52 de Macaé, 52 de São Paulo e 27 de Maceió) foram caracterizados quanto ao teor de contaminantes, à distribuição granulométrica, distribuição de densidade, propriedades físicas (absorção de água e massa específica aparente) e teor de finos.

O objetivo da caracterização foi analisar a qualidade dos agregados de RCD regionais segundo os principais parâmetros e as diferentes origens.

Todos os lotes foram pesados, tendo em vista que o volume destes foi fixado na etapa de amostragem; em seguida, cada um dos lotes foi submetido à peneiramento a seco em telas de abertura de 80 a $25,4 \mathrm{~mm}$, gerando três frações granulométricas: $+80 ;-80+25,4$ e $-25,4 \mathrm{~mm}$.

Nas frações maiores que $25,4 \mathrm{~mm}(+80,-80+25)$, os materiais indesejáveis como madeira, plástico, papel, betume, metais ferrosos e metais não ferrosos, assim como contaminantes, tais como vidro, gesso e cimento amianto, foram separados através de seleção manual (catação).

A fração menor que $25,4 \mathrm{~mm}$ foi homogeneizada em pilha alongada para amostragem de uma alíquota de 1/10 do volume para o peneiramento do agregado graúdo $(-25,4 \mathrm{~mm})$. Em seguida, esta foi peneirada a seco na tela de $4,8 \mathrm{~mm}$, gerando duas frações: $-25,4+4,8 ;-4,8$. O agregado miúdo $(-4,8 \mathrm{~mm})$, o teor de umidade foi determinado, assim como o teor de finos. Após a lavagem do agregado graúdo, a distribuição de massa na densidade foi avaliada, através da separação sequencial nas seguintes densidades $\left(e \mathrm{~m} \mathrm{~g} / \mathrm{cm}^{3}\right): d<1,9 ; 1,9<\mathrm{d}<2,2$ e $\mathrm{d}>2,2$. Os materiais indesejáveis, contaminantes e 0 teor de cerâmica vermelha foram determinados, por catação, nos três produtos de separação por densidade e calculados por todo agregado graúdo, por ponderação de massa.

Em seguida, os produtos de densidade, ou parte deles, foram caracterizados quanto a absorção de água e massa específica aparente.

Ver Apêndice A com as operações de catação e processamento. 


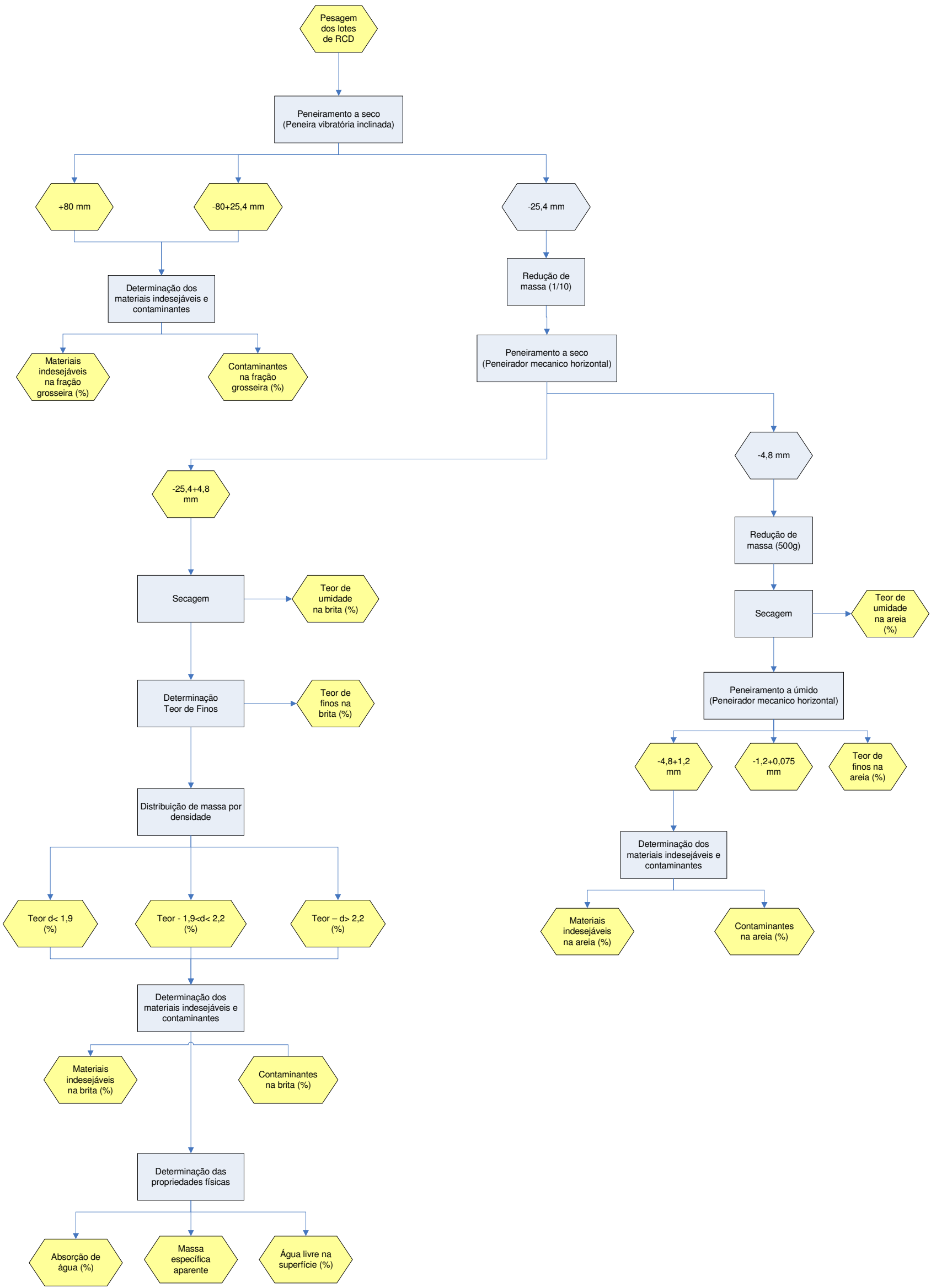

Figura 4.23 - Fluxograma geral das atividades de caracterização dos lotes. 

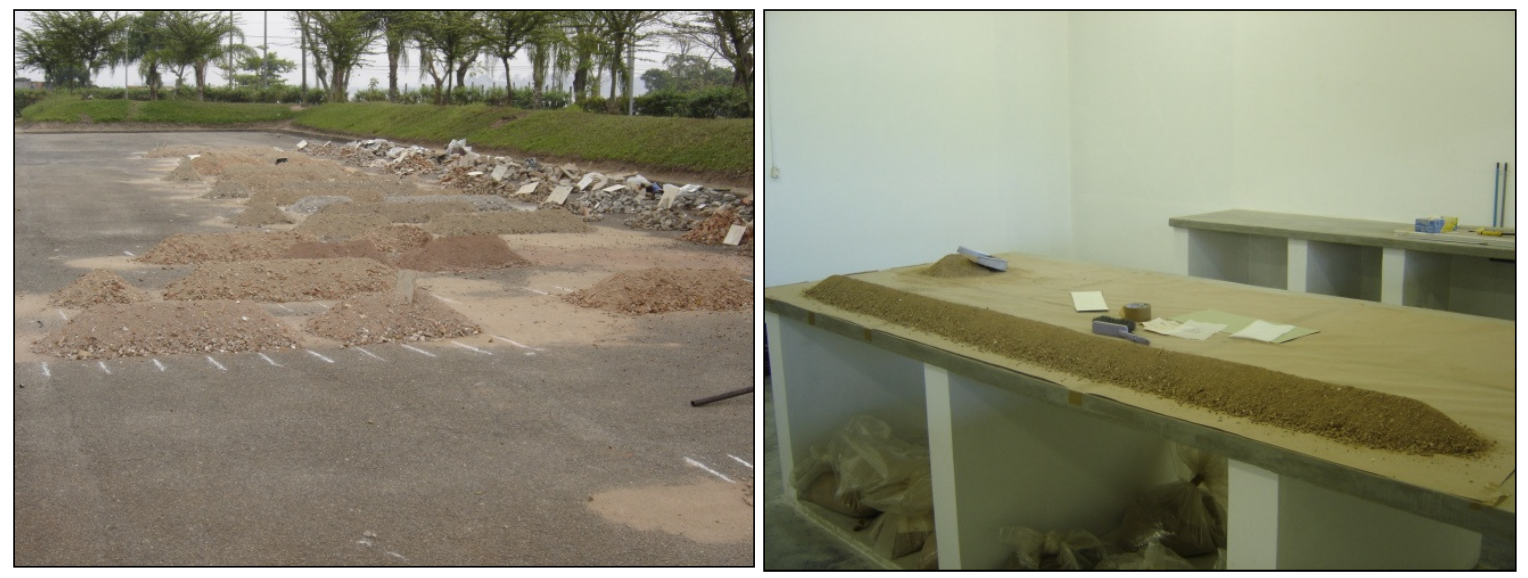

Figura 4.24 - Pilhas alongadas da fração menor que $25,4 \mathrm{~mm}$ e da fração menor que $4,8 \mathrm{~mm}$.

\subsection{DISTRIBUIÇÃO GRANULOMÉTRICA}

A distribuição granulométrica do agregado graúdo foi realizada por peneiramento a seco para obtenção de produtos nos seguintes intervalos granulométricos: +80 , $80+25,4 ;-25,4+4,8 \mathrm{~mm}$ (com massa reduzida). A Figura 4.25 (a) mostra 0 peneirador vertical inclinado de escala piloto utilizado com as peneiras de abertura de malha 80 e $25,4 \mathrm{~mm}$. O peneiramento da fração 25,4 e 4,8 foi realizado com peneirador vibratório horizontal, Figura 4.25 (b).

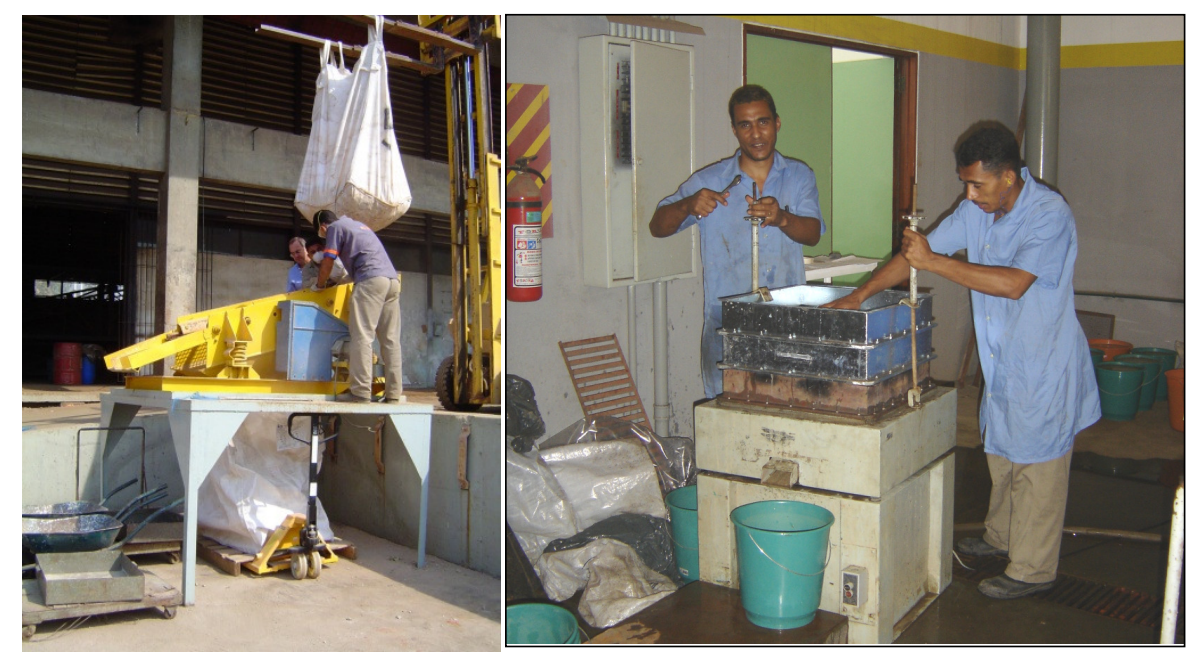

(a)

(b)

Figura 4.25 - (a) Peneirador vertical inclinado, escala piloto e (b) peneirador vibratório horizontal. 
A fração $-4,8 \mathrm{~mm}$ foi peneirada a úmido com peneiras circulares (Figura 4.26) com abertura de malha 1,2 e $0,075 \mathrm{~mm}$, escala de laboratório. As seguintes frações foram geradas: $-4,8+1,2 ;-1,2+0,074$ e $-0,074 \mathrm{~mm}$.
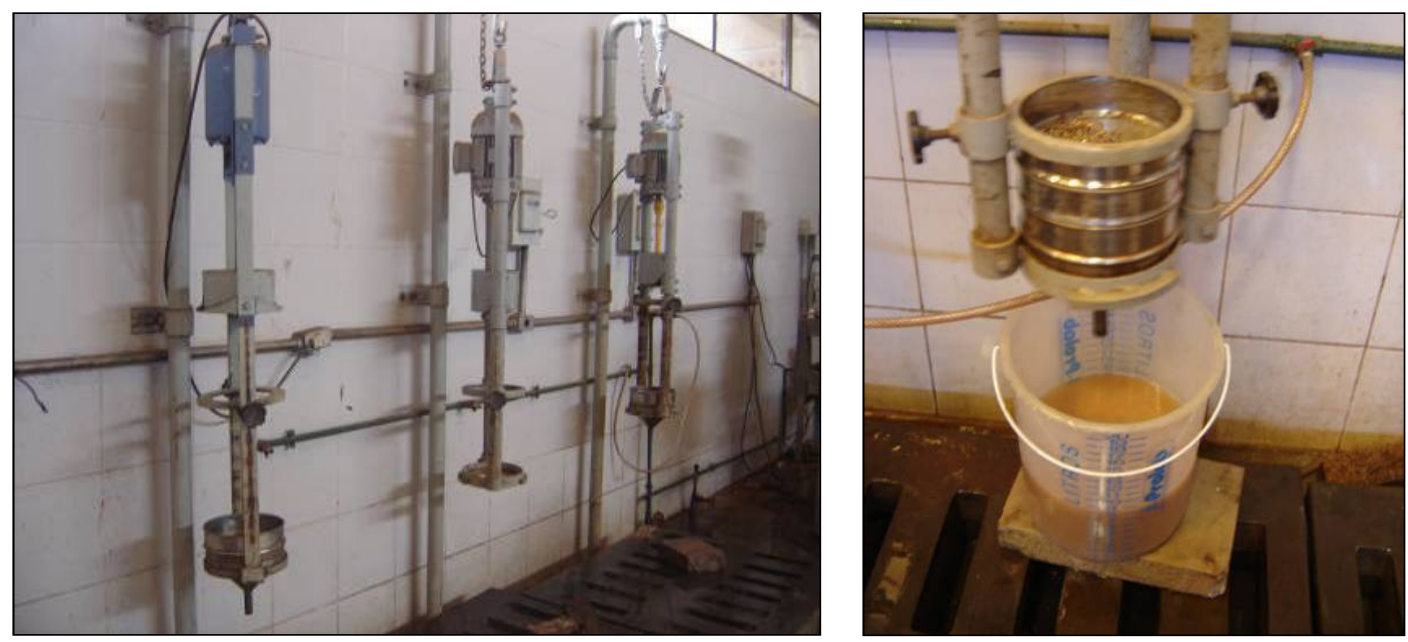

Figura 4.26 - Peneiramento a úmido com peneiras circulares.

As massas dessas frações foram determinadas e suas porcentagens foram utilizadas para a construção das curvas de distribuição granulométricas. A fração $0,074 \mathrm{~mm}$ é o que se denomina "teor de finos" da amostra.

\subsection{TEOR DE CONTAMINANTES}

O teor de contaminantes foi avaliado através de seleção manual ("catação"), que é uma operação manual de retirada de determinadas fases. A operação foi realizada para cada intervelo granulométrico, respectivamente: +80 ; $-80+25,4$ e $-25,4+4,8$ $\mathrm{mm}$.

Para os lotes de RCD foram separados os seguintes componentes: madeira, plástico, papel, betume, material ferroso, alumínio, vidro, gesso e cimento amianto. Cada qual foi pesado e calculado a sua proporção (em massa) relativa à massa total do lote.

O objetivo foi avaliar o grau de contaminação dos lotes e verificar a necessidade de se empregar operações de triagem. 


\subsection{DISTRIBUIÇÃO DE DENSIDADE}

A distribuição de densidade do agregado graúdo foi obtida através de ensaio de separação densitária em cone de meio denso (Figura 4.27a), empregando-se uma polpa de ferrosilício com densidade de 1,9 e $2,2 \mathrm{~g} / \mathrm{cm}^{3}$.

A água é adicionada no equipamento, até iniciar a circulação. Em seguida, o ferro silício é adicionado, progressivamente, até a polpa com água adquirir a densidade desejada, com variação admissível de $\pm 0,01 \mathrm{~g} / \mathrm{cm}^{3}$. A densidade de polpa é determinada pela razão da massa e do volume em uma proveta graduada de 1000 $\mathrm{mL}$, coletada em intervalos regulares de 5 segundos. Ela é monitorada, periodicamente, a cada três baldes de $8 \mathrm{~L}$ de agregados alimentados.

O agregado graúdo $(-25,4+4,8 \mathrm{~mm})$ foi separado em três produtos de densidade de $<1,9 ; 1,9<\mathrm{d}<2,2 ; \mathrm{d}<2,2$. As massas dos produtos foram secas a $105^{\circ} \mathrm{C}$, durante 24 horas, e os valores de massa expressos percentualmente.

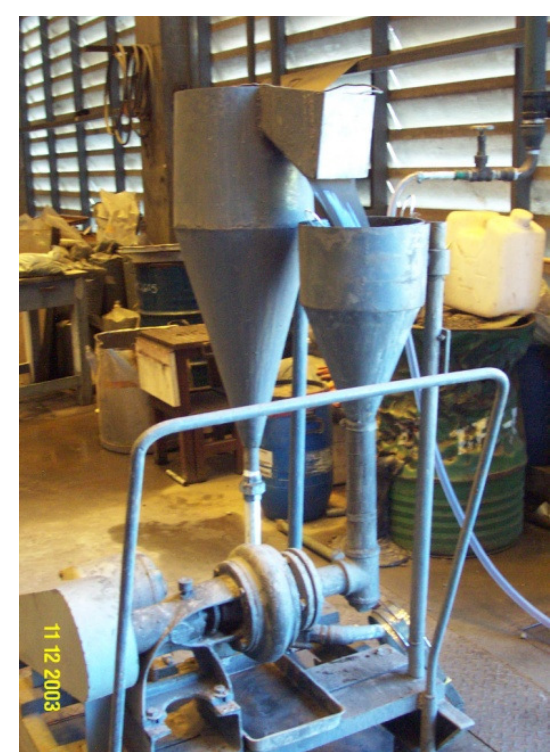

(a)

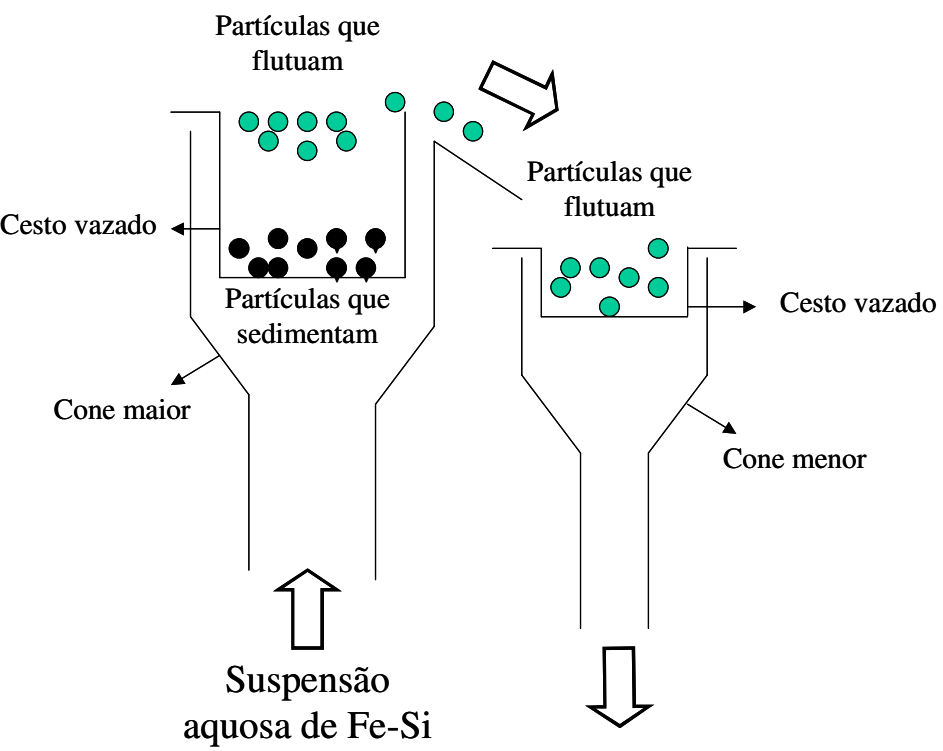

(b)

Figura 4.27 - Cone de separação em meio denso (a) e desenho esquemático do funcionamento (b). 


\subsection{CLASSIFICAÇÃO DOS LOTES DE RCD PELA DISTRIBUIÇÃO DE DENSIDADE}

Determinaram-se lotes de agregados de alta qualidade aqueles com mais de $30 \%$ da massa com $\mathrm{d}>2,2 \mathrm{~g} / \mathrm{cm}^{3}$, representando um material com densidade média de um concreto, igual ou superior a 2,2.

Após a seleção dos lotes de Alta Qualidade, os lotes de agregados de baixa qualidade são aqueles com mais de $30 \%$ em massa com $\mathrm{d}<1,9 \mathrm{~g} / \mathrm{cm}^{3}$. Lotes de média qualidade foram os que não se enquadraram em nenhuma das duas definições.

Os balanços de massa dos lotes de alta qualidade em relação aos demais foram calculados nas três cidades.

\subsection{COMPOSIÇÃO DOS LOTES NOS GRUPOS DE QUALIDADE}

O objetivo foi iniciar o processamento com RCD de qualidades distintas e de diferentes cidades, e avaliar a capacidade deste em neutralizá-las, gerando um produto homogêneo, bem como avaliar se há necessidade de se processar separadamente materiais de diferentes qualidades e diferentes cidades.

Os grupos de qualidade entre as cidades são significativamente diferentes entre si, visto que as amostras apresentam grande disparidade entre o teor de material nos intervalos de densidade. Exemplificando, o lote de $A Q$ de Macaé apresenta de 30 a $70 \%$ de massa em $d>2,2$, para São Paulo esse valor se eleva para 70 a $80 \%$, enquanto que para Maceió é de 17 a $33 \%$, mostrando que os resíduos das três cidades são distintos, e que os grupos de qualidade são definidos para cada origem de RCD e não por proporção de material com d>2,2. 


\subsubsection{Macaé}

A Tabela 4.6, Figura 4.28 e Figura 4.29 apresentam as propriedades dos lotes dos grupos de qualidade $(A Q, M Q$ e $B Q)$.

Tabela 4.6 - Lotes que compõem os grupos de qualidade, RCD Macaé.

\begin{tabular}{|c|c|c|c|c|c|c|}
\hline \multirow{3}{*}{$\begin{array}{l}\text { Lotes } \\
\text { amostrados }\end{array}$} & \multicolumn{3}{|c|}{ Propriedade do lote } & \multicolumn{3}{|c|}{ Propriedade do agregado graúdo } \\
\hline & \multicolumn{3}{|c|}{$\begin{array}{l}\text { Distribuição de massa (\%) por } \\
\text { fração granulométrica }(\mathrm{mm})\end{array}$} & \multicolumn{3}{|c|}{$\begin{array}{c}\text { Distribuição de massa por } \\
\text { densidade }\left(\mathrm{g} / \mathrm{cm}^{3}\right)\end{array}$} \\
\hline & $+25,4$ & $-25,4+4,8$ & $-4,8$ & $d<1,9$ & $1,9<d<2,2$ & $d>2,2$ \\
\hline $26-I$ & 60,6 & 11,3 & 28,2 & 21,8 & 34,5 & 43,7 \\
\hline $33-1$ & 84,7 & 5,18 & 10,1 & 20,1 & 49,8 & 30,1 \\
\hline $31-I I$ & 54,8 & 7,07 & 38,1 & 10,1 & 22,2 & 67,7 \\
\hline AQ - Macaé & 67,0 & 7,65 & 25,3 & 17,1 & 35,5 & 47,4 \\
\hline $02-1$ & 55,4 & 7,56 & 37,0 & 55,9 & 22,3 & 21,8 \\
\hline 05-I & 25,1 & 16,2 & 58,8 & 51,2 & 25,3 & 23,5 \\
\hline MQ - Macaé & 42,3 & 11,3 & 46,4 & 53,9 & 23,6 & 22,5 \\
\hline $23-I I$ & 35,1 & 26,4 & 38,5 & 62,6 & 28,3 & 9,13 \\
\hline 02-II & 37,6 & 15,8 & 46,6 & 79,1 & 20,9 & 0,00 \\
\hline BQ - Macaé & 36,2 & 21,7 & 42,1 & 69,9 & 25,0 & 5,13 \\
\hline
\end{tabular}

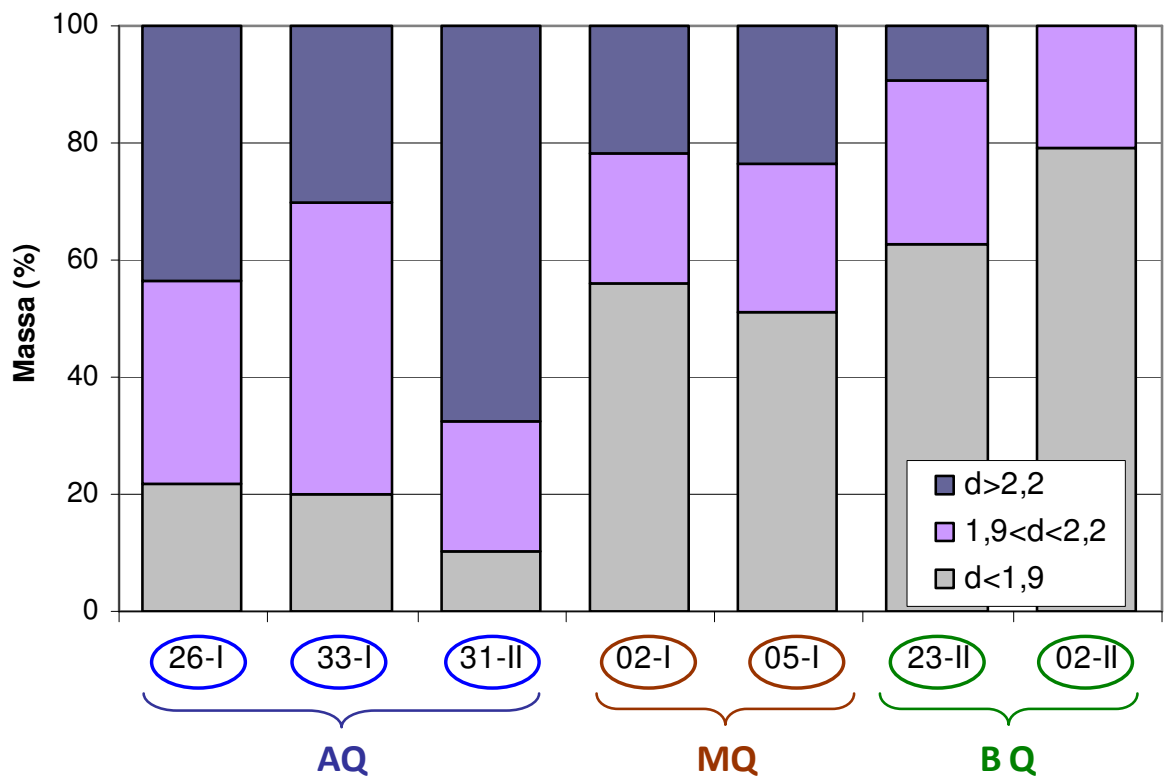

Figura 4.28 - Distribuição por densidade dos lotes que compõem os grupos de qualidade, RCD Macaé. 


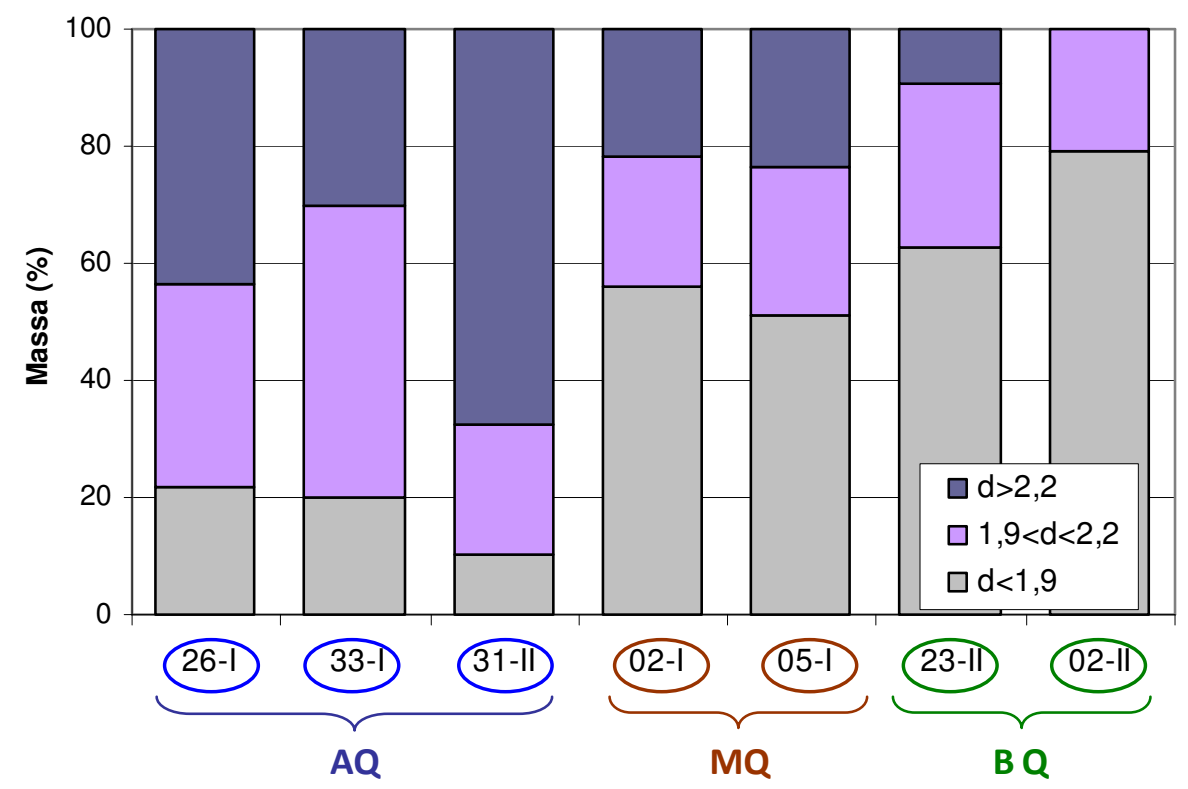

Figura 4.29 - Distribuição por densidade dos grupos de qualidade, RCD Macaé.

\subsubsection{Maceió}

A Tabela 4.7, Figura 4.30 e Figura 4.31 apresentam as propriedades dos lotes dos grupos de qualidade $(A Q, M Q$ e $B Q)$.

Tabela 4.7 - Lotes que compõem os grupos de qualidade, RCD Maceió.

\begin{tabular}{|c|c|c|c|c|c|c|}
\hline \multirow{3}{*}{$\begin{array}{l}\text { Lotes } \\
\text { amostrados }\end{array}$} & \multicolumn{3}{|c|}{ Propriedade do lote } & \multicolumn{3}{|c|}{ Propriedade do agregado graúdo } \\
\hline & \multicolumn{3}{|c|}{$\begin{array}{l}\text { Distribuição de massa }(\%) \text { por } \\
\text { fração granulométrica }(\mathrm{mm})\end{array}$} & \multicolumn{3}{|c|}{$\begin{array}{l}\text { Distribuição de massa por } \\
\text { densidade }\left(\mathrm{g} / \mathrm{cm}^{3}\right)\end{array}$} \\
\hline & $+25,4$ & $-25,4+4,8$ & $-4,8$ & $d<1,9$ & $1,9<d<2,2$ & $d>2,2$ \\
\hline 1 & 72,3 & 11,5 & 16,2 & 47,0 & 27,0 & 26,0 \\
\hline 35 & 67,8 & 8,2 & 24,0 & 39,7 & 26,9 & 33,4 \\
\hline 43 & 57,2 & 8,0 & 34,9 & 46,2 & 36,7 & 17,1 \\
\hline AQ - Maceió & 66,6 & 9,5 & 23,9 & 44,6 & 29,8 & 25,6 \\
\hline 3 & 63,9 & 11,8 & 24,3 & 33,9 & 61,3 & 4,85 \\
\hline 33 & 66,5 & 7,7 & 25,9 & 58,9 & 33,9 & 7,25 \\
\hline 44 & 52,7 & 17,3 & 30,0 & 52,6 & 39,5 & 7,86 \\
\hline MQ - Maceió & 59,1 & 13,5 & 27,3 & 47,9 & 45,3 & 6,77 \\
\hline 7 & 71,5 & 8,6 & 19,9 & 89,4 & 5,76 & 4,88 \\
\hline 23 & 62,8 & 10,5 & 26,7 & 94,2 & 5,77 & 0,00 \\
\hline 45 & 72,0 & 7,3 & 20,7 & 94,1 & 5,87 & 0,00 \\
\hline BQ - Maceió & 68,2 & 9,0 & 22,8 & 92,6 & 5,80 & 1,59 \\
\hline
\end{tabular}




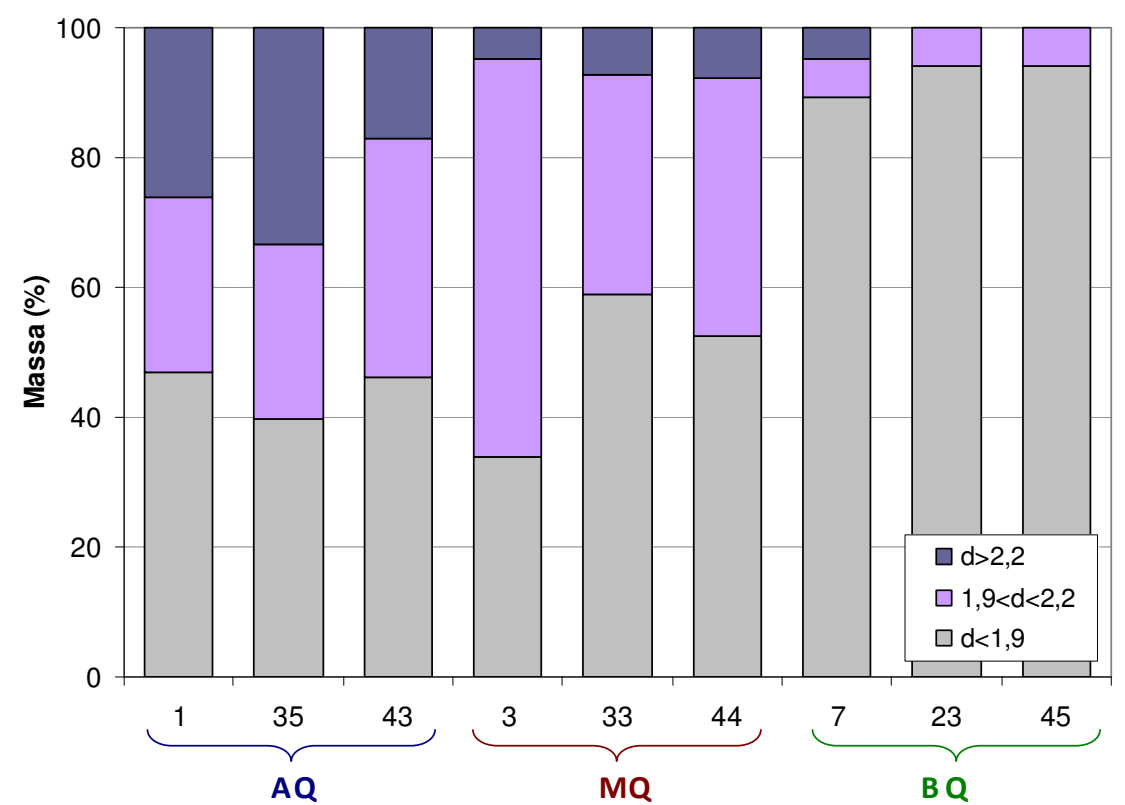

Figura 4.30 - Distribuição por densidade dos lotes que compõem os grupos de qualidade, RCD Maceió.

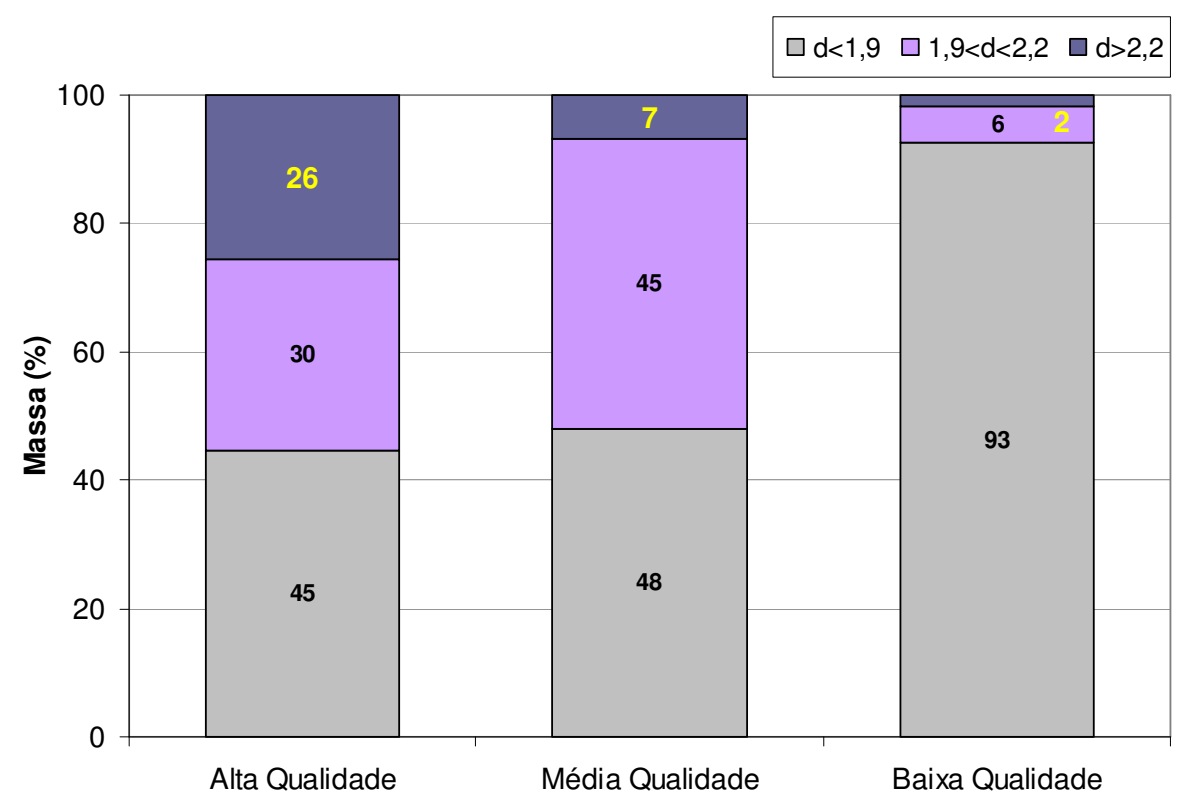

Figura 4.31 - Distribuição por densidade dos grupos de qualidade, RCD Maceió.

\subsubsection{Distribuição granulométrica}

\subsubsection{Macaé}

A Figura 4.32 e Figura 4.33 apresentam as massas acumuladas por fração granulométrica, tanto da $1^{\underline{a}}$ como da $2^{\underline{a}}$ amostragem. Existe grande variabilidade no RCD para os diversos lotes estudados. 


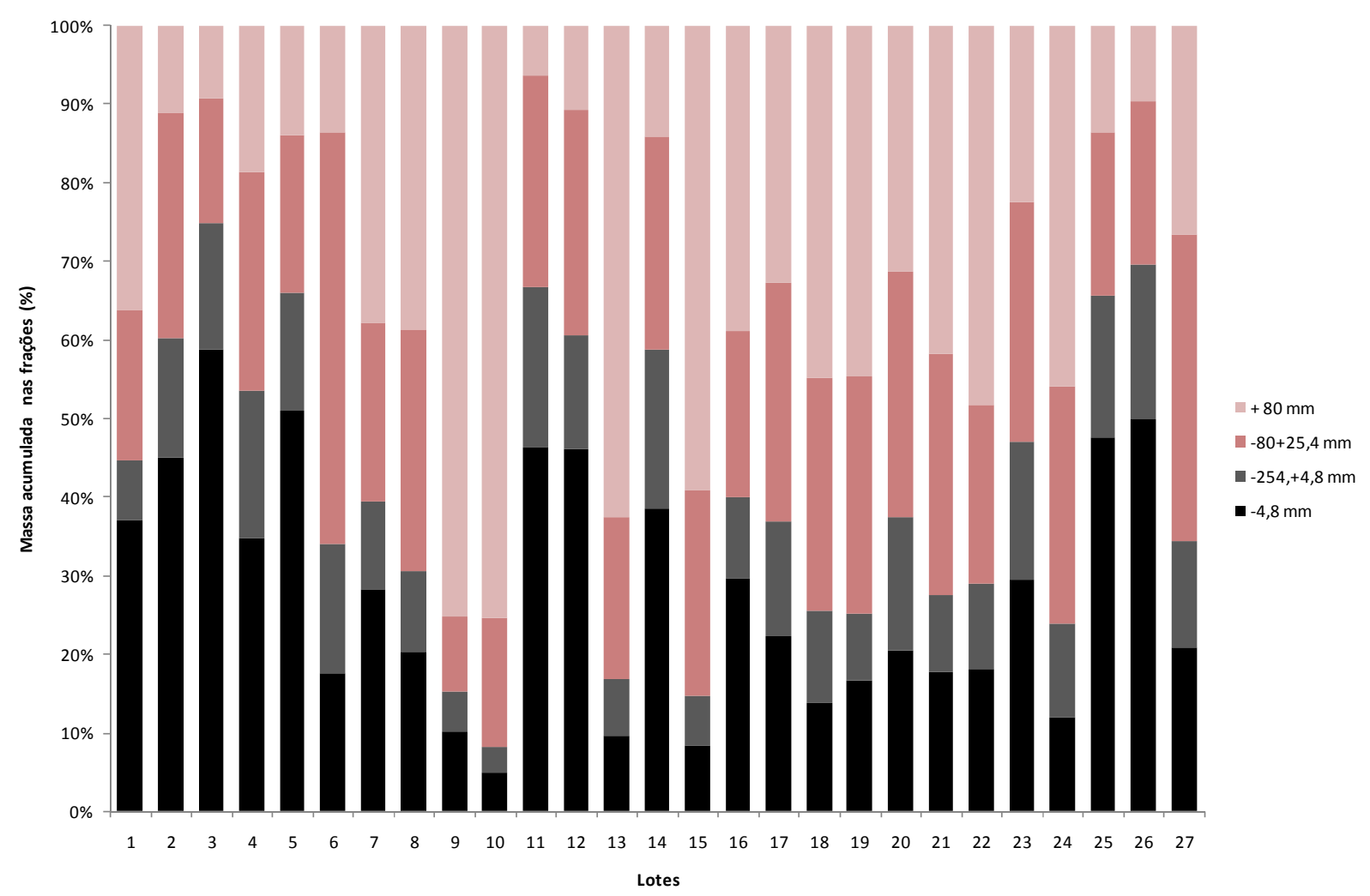

Figura 4.32 - Massa acumulada por fração granulométrica, lotes da 1ª amostragem, Macaé.

Verifica-se que uma grande parcela dos lotes (metade) apresenta mais de $50 \%$ da massa já na granulometria de agregado $(-25,4 \mathrm{~mm})$. 


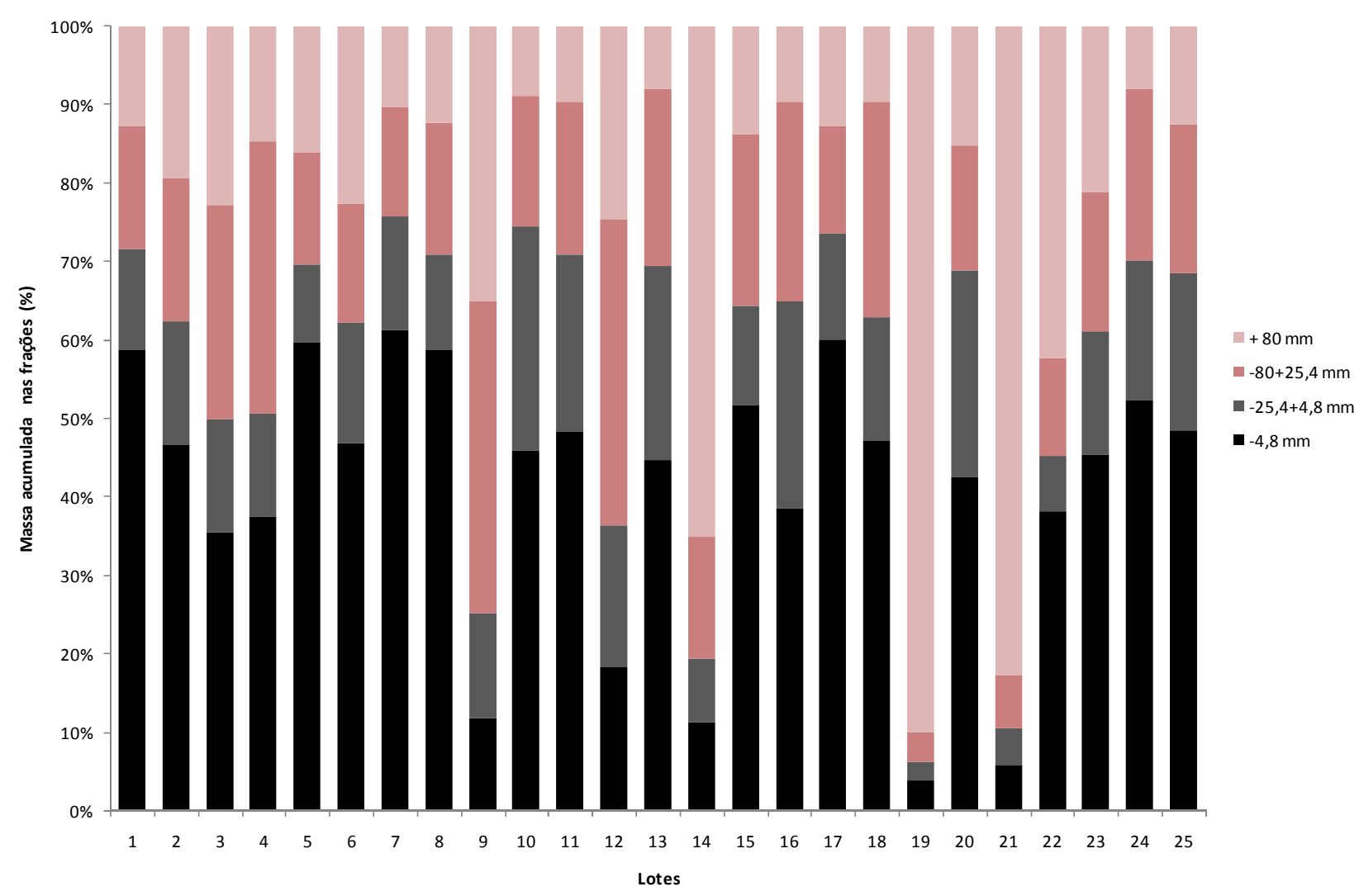

Figura 4.33 - Massa acumulada por fração granulométrica, lotes da $2^{\mathrm{a}}$ amostragem, Macaé.

Na Figura 4.34 são apresentados os gráficos comparativos médios da $1^{\underline{\underline{a}}}$ e $2^{\underline{a}}$ amostragens, bem como a média para a cidade de Macaé determinada pela composição proporcional dos lotes estudados.

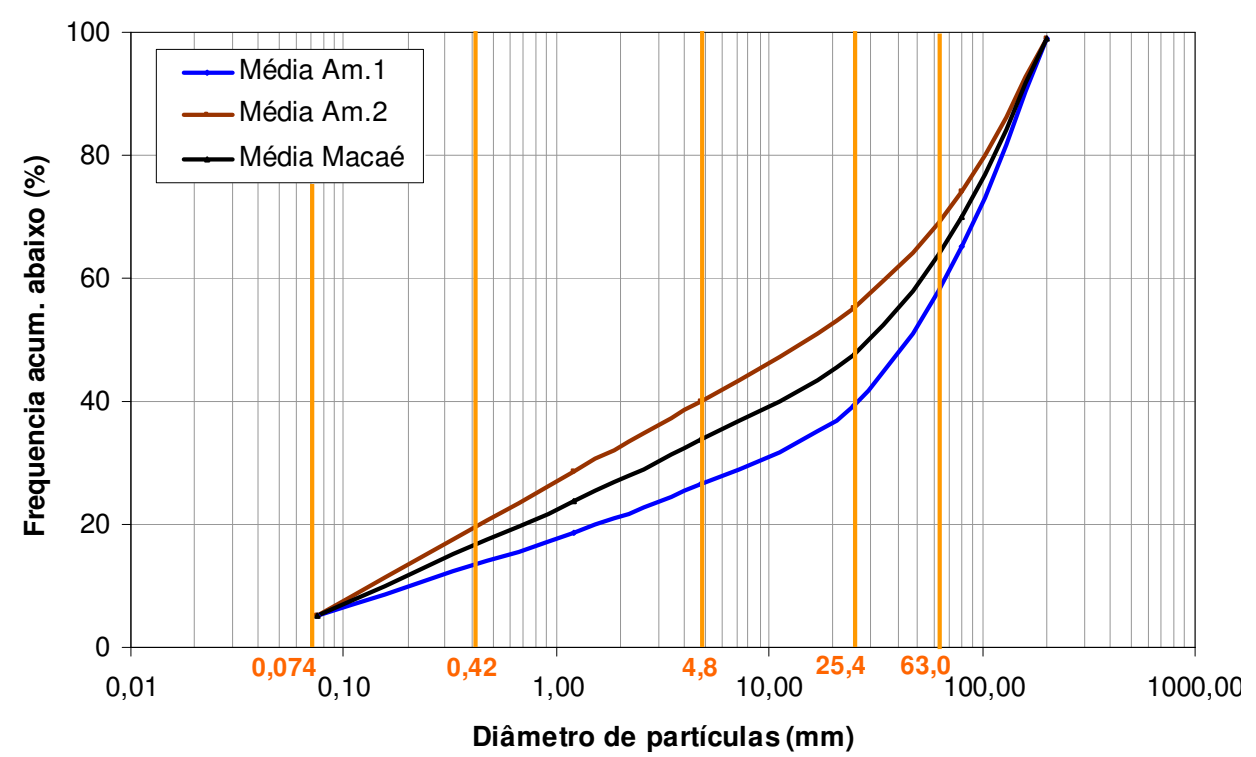

Figura 4.34 - Distribuição granulométrica média da cidade de Macaé. 
A quantidade de material na faixa de agregado para pavimentação (abaixo de 83 $\mathrm{mm}$ ) é em média, $65 \%$ da massa do resíduo de Macaé e pode ter aplicação direta como agregado para sub-fase e base de pavimentação. A quantidade média de material abaixo de $0,42 \mathrm{~mm}$ é maior que $10 \%$, atendendo as especificações para aplicações em pavimentos.

\subsubsection{São Paulo}

A Figura 4.35 e Figura 4.36 apresentam as massas acumuladas por fração granulométrica dos lotes da cidade de São Paulo. Existe grande variabilidade no RCD para os diversos lotes estudados. Parte dos lotes (menos da metade) apresenta mais de $50 \%$ da massa já na granulometria de agregado $(-25,4 \mathrm{~mm})$.

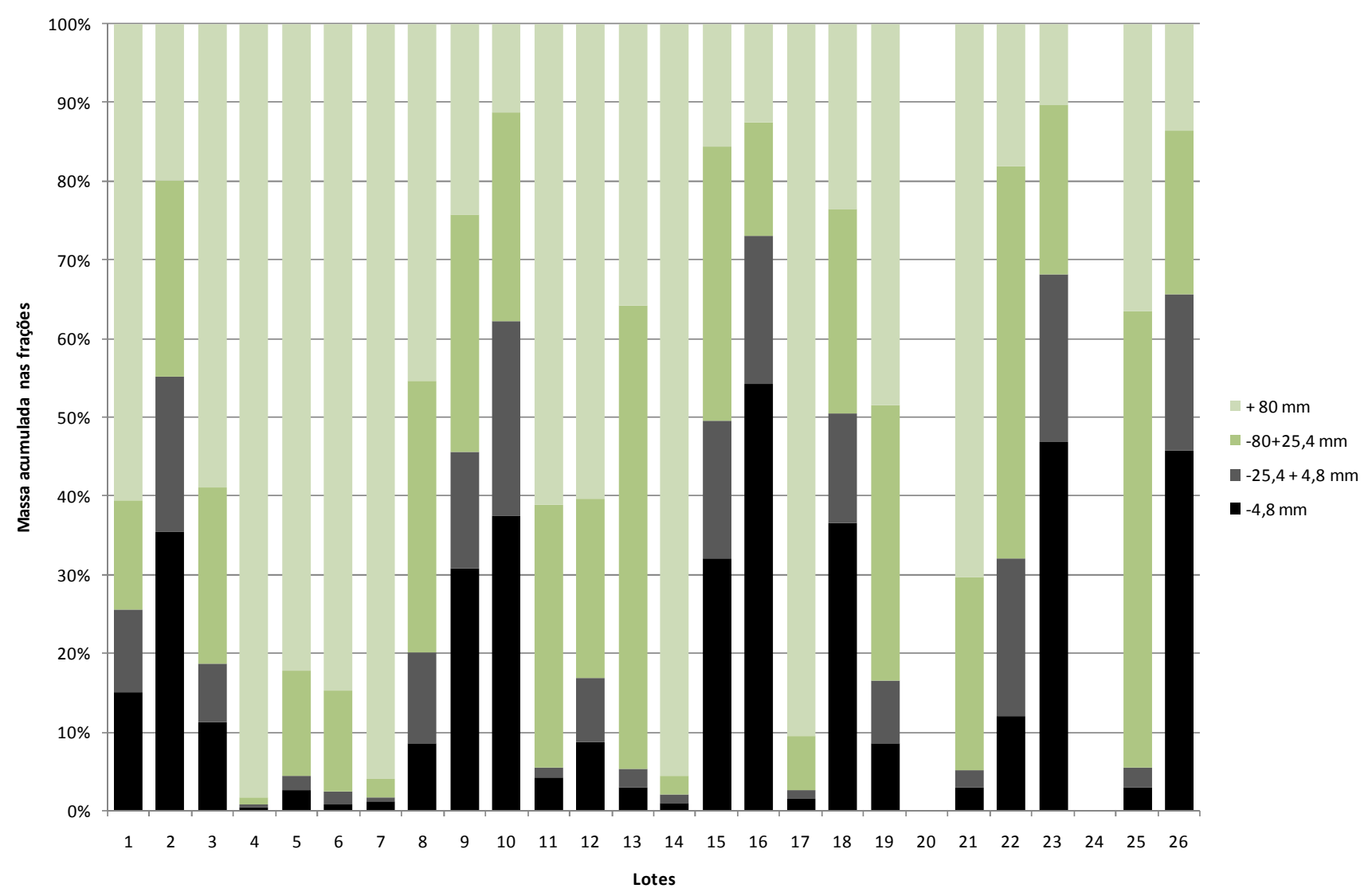

Figura 4.35 - Massa acumulada por fração granulométrica, lotes (1 a 26) de São Paulo (primeira amostragem). 


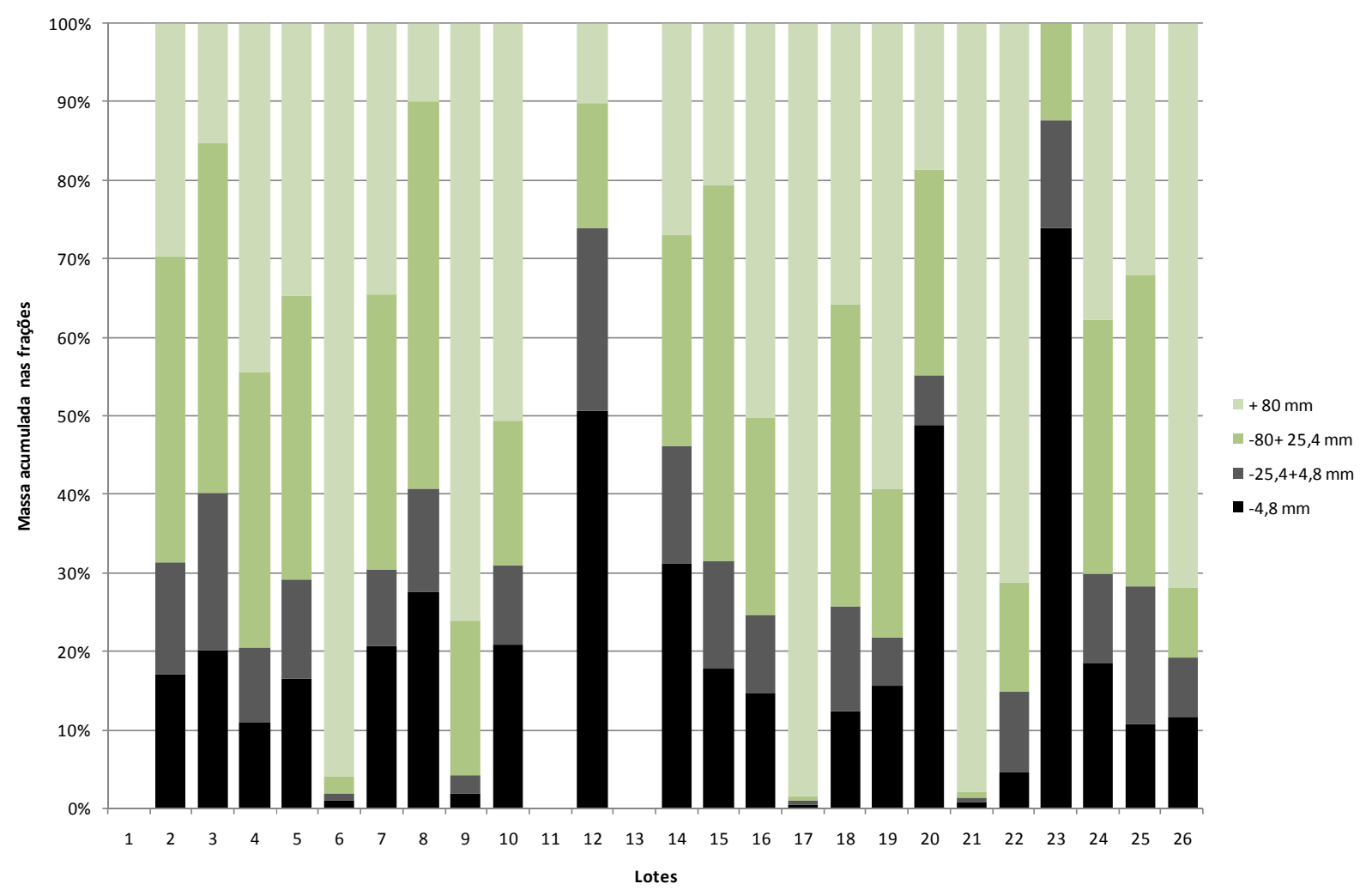

Figura 4.36 - Massa acumulada por fração granulométrica, lotes (1 a 26) de São Paulo (segunda amostragem).

$\mathrm{Na}$ Figura 4.37 são apresentadas as distribuições granulométricas dos lotes da cidade de São Paulo, bem como a média determinada pela composição proporcional dos lotes. A quantidade de material na faixa de agregado para pavimentação (abaixo de $83 \mathrm{~mm}$ ) é em média $45 \%$ da massa do resíduo de São Paulo e pode ter aplicação direta como agregado para sub-base e base de pavimentação. A quantidade média de material abaixo de $0,42 \mathrm{~mm}$ é próximo de $10 \%$, que é o limite das especificações para aplicações em pavimentos. 


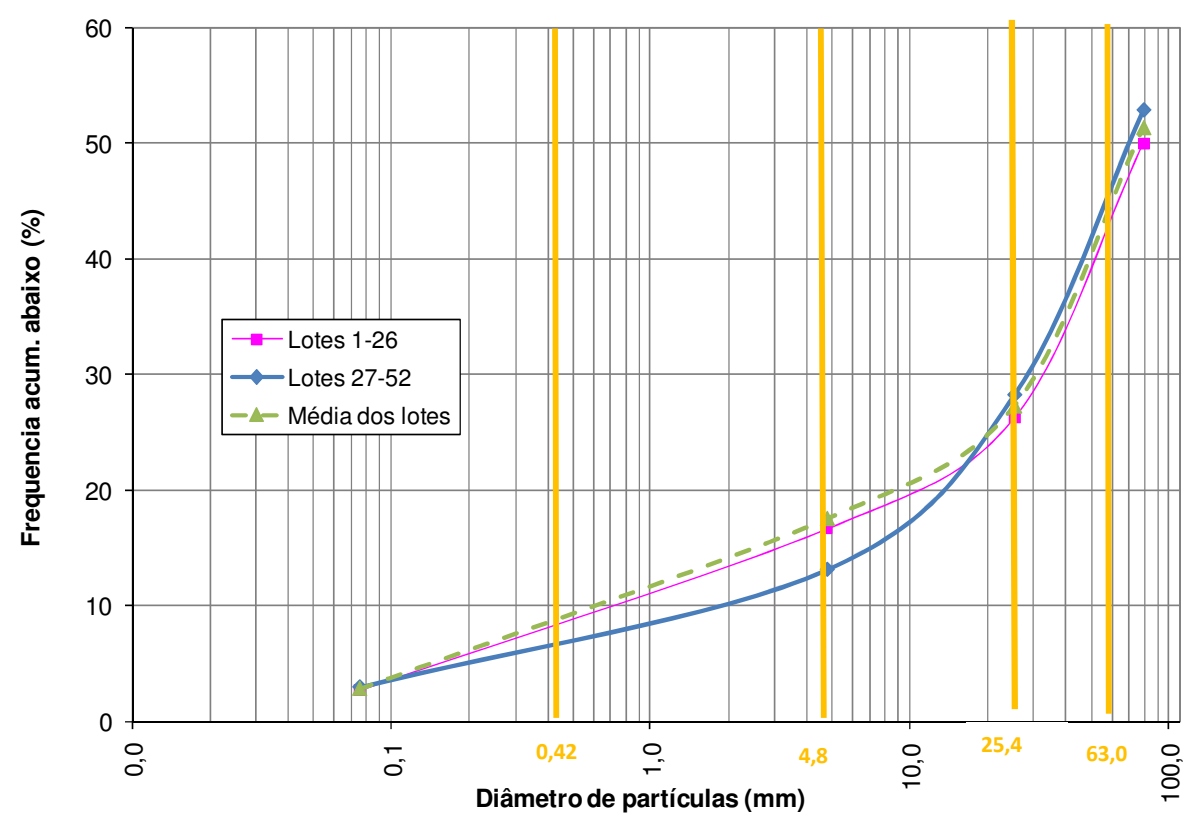

Figura 4.37 - Distribuição granulométrica média da cidade de São Paulo.

\subsubsection{Maceió}

A Figura 4.38 mostra a massa acumulada por fração granulométrica dos lotes da cidade de Maceió. Existe grande variabilidade no RCD para os diversos lotes estudados. Os lotes apresentam de 10 a $50 \%$ da massa já na granulometria de agregado $(-25,4 \mathrm{~mm})$.

$\mathrm{Na}$ Figura 4.39 é apresentada a distribuição granulométrica média dos lotes da cidade de Maceió, determinada pela composição proporcional dos lotes. A quantidade de material na faixa de agregado para pavimentação (abaixo de $63 \mathrm{~mm}$ ) é em média, $60 \%$ da massa do resíduo de Maceió e pode ter aplicação direta como agregado para sub-base e base de pavimentação. A quantidade média de material abaixo de 0,42 mm está acima de 10\%, que é o limite das especificações para aplicações em pavimentos. 


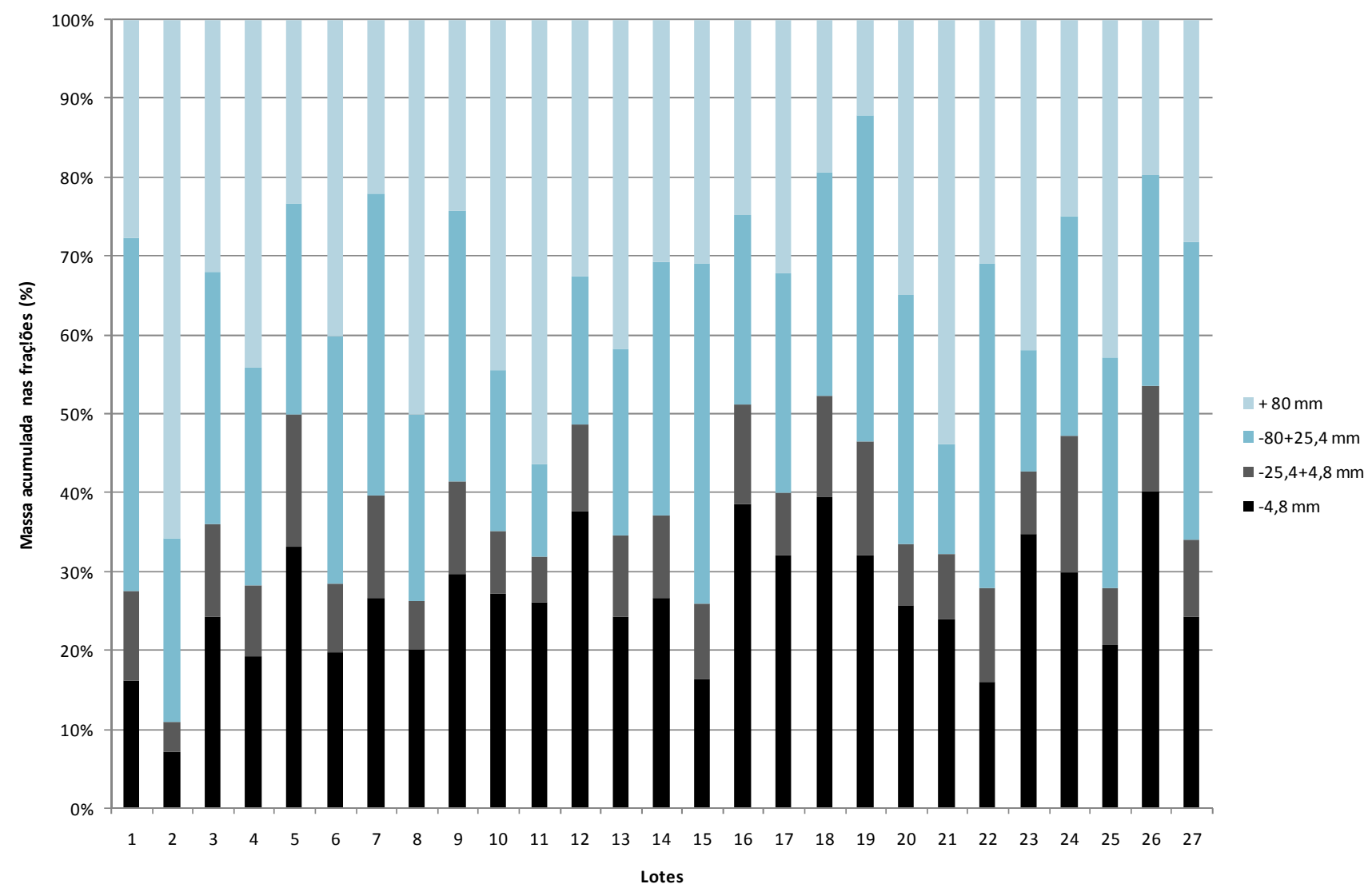

Figura 4.38 - Massa acumulada por fração granulométrica, lotes de Maceió.

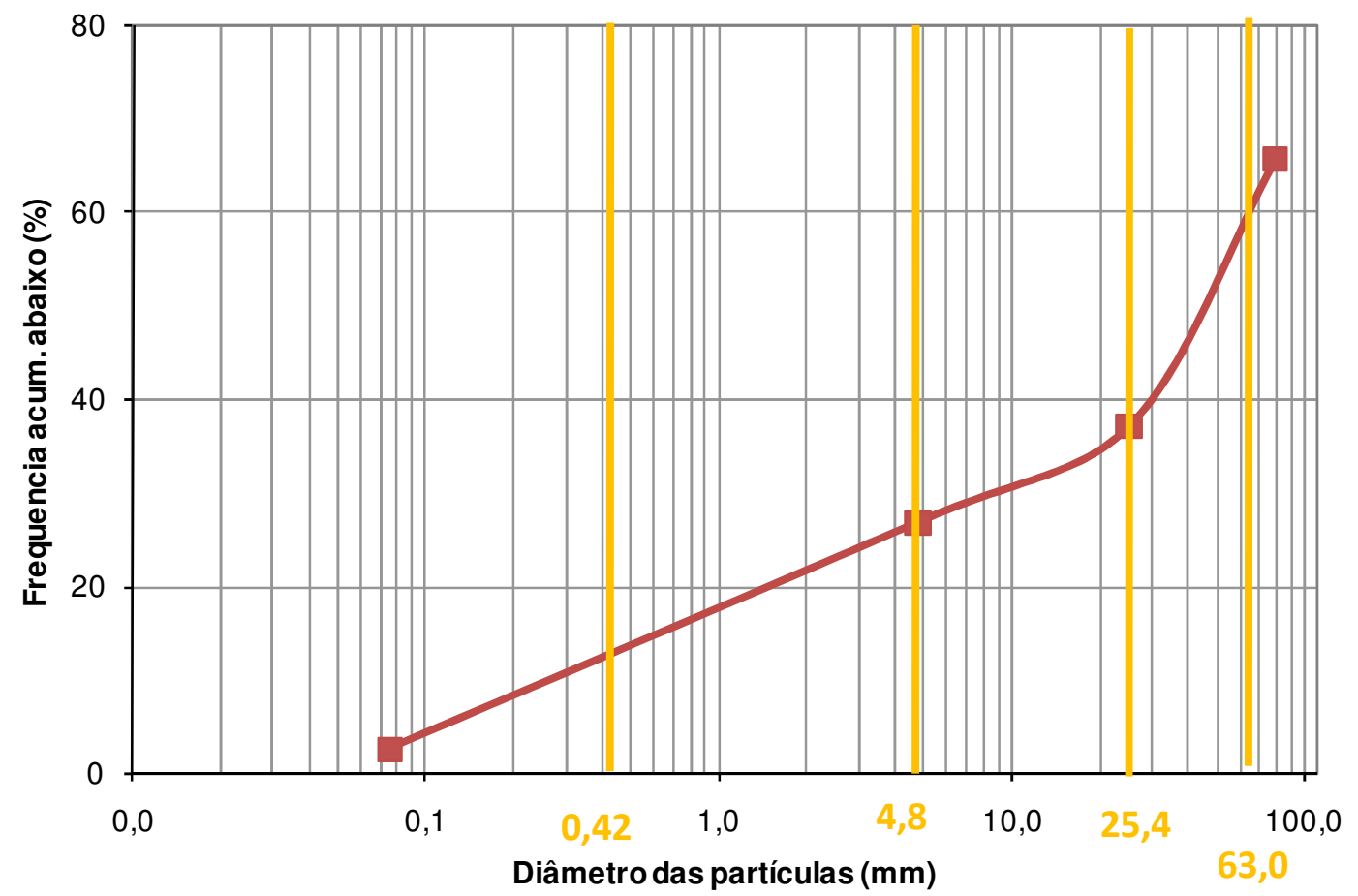

Figura 4.39 - Distribuição granulométrica média na cidade de Maceió. 


\subsection{COMPARAÇÃO ENTRE AS CIDADES}

É possível obter-se $65 \%$ de massa do resíduo das três cidades como agregados para pavimentos empregando simplesmente um sistema de escalpe (sem britagem) para remoção da fração $+63 \mathrm{~mm}$. Pode-se, portanto, gerar agregados para pavimentos sem investir em britagem. Esta medida reduz drasticamente os investimentos e a complexidade da implantação e operação de usinas de reciclagem. A fração $-63 \mathrm{~mm}$ pode ainda ser utilizada como rachão ou enviada para aterro.

Além disso, a remoção da fração $-63 \mathrm{~mm}$ (ou -25,4 mm) aumenta significativamente a produtividade na britagem e consequentemente reduz o consumo de energia de processamento. Esta prática não foi detectada nas usinas brasileiras. A remoção da fração fina antes da britagem (escalpe) através de peneiramento ou grelha vibratória aumenta a disponibilidade dos britadores bem como reduz a geração de finos (indesejáveis para o processo). No caso de uma nova instalação, essa medida permite reduzir o tamanho do equipamento a ser adquirido, reduzindo os investimentos e custos operacionais.

Com a operação de escalpe, a distribuição granulométrica do passante $(-63 \mathrm{~mm})$ se torna mais fina (Figura 4.40), com acréscimo nos teores da fração passando em 9,42 $\mathrm{mm}(20$ a $40 \%)$. 


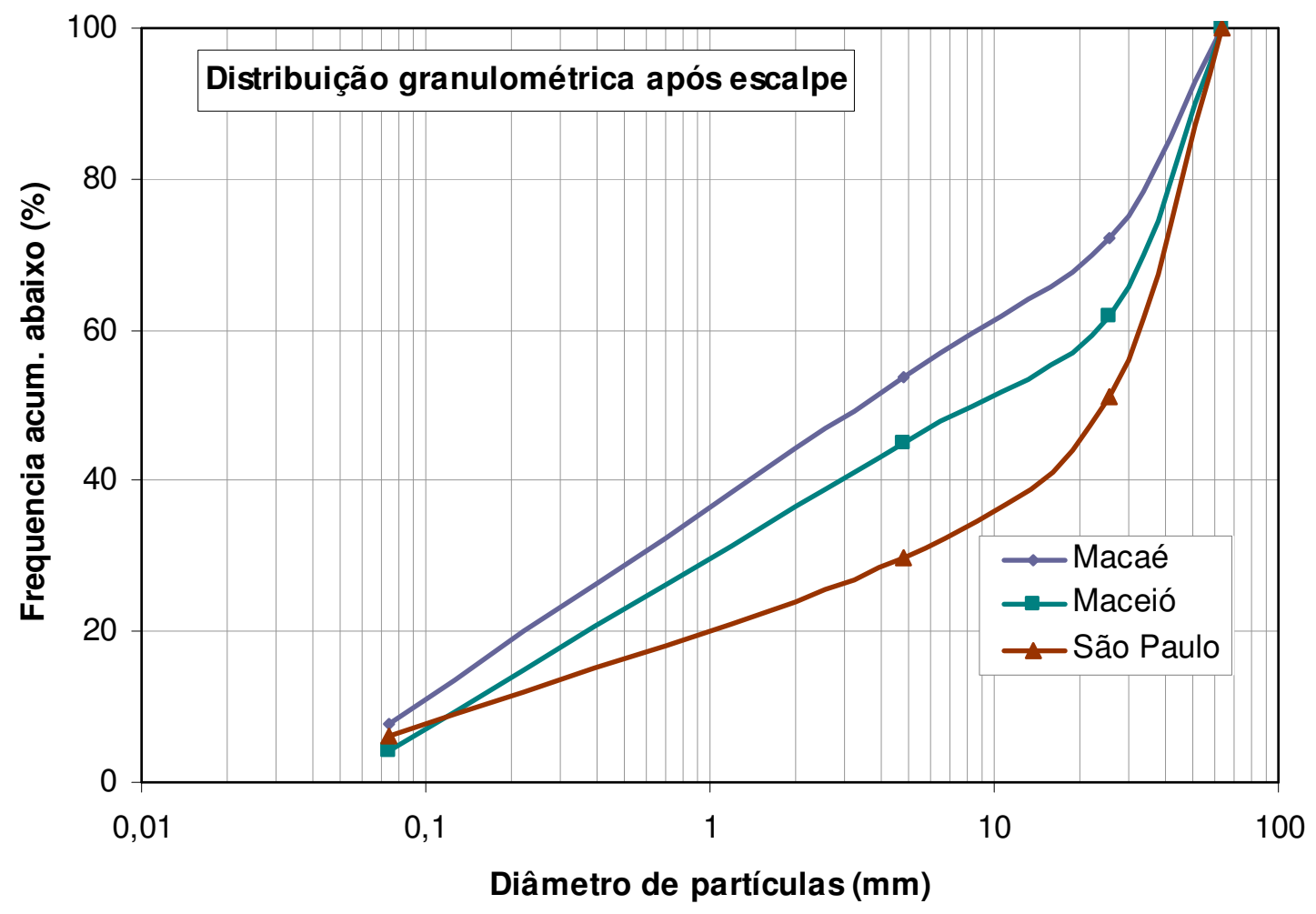

Figura 4.40 - Distribuição granulométrica da fração -63 mm, após o escalpe.

\subsection{MATERIAIS CONTAMINANTES}

\subsubsection{Macaé}

A Figura 4.41 e Figura 4.42 apresentam os teores de contaminantes (orgânicos, inorgânicos, gesso e cimento amianto) nos lotes de RCD de Macaé. Existe uma grande variabilidade de tipos de contaminantes e sua concentração. Os principais contaminantes são os materiais orgânicos (madeira, plástico e papel), especialmente a madeira, gesso e cimento amianto. Eles ultrapassam limites usuais estabelecidos por normas (Figura 4.43). 


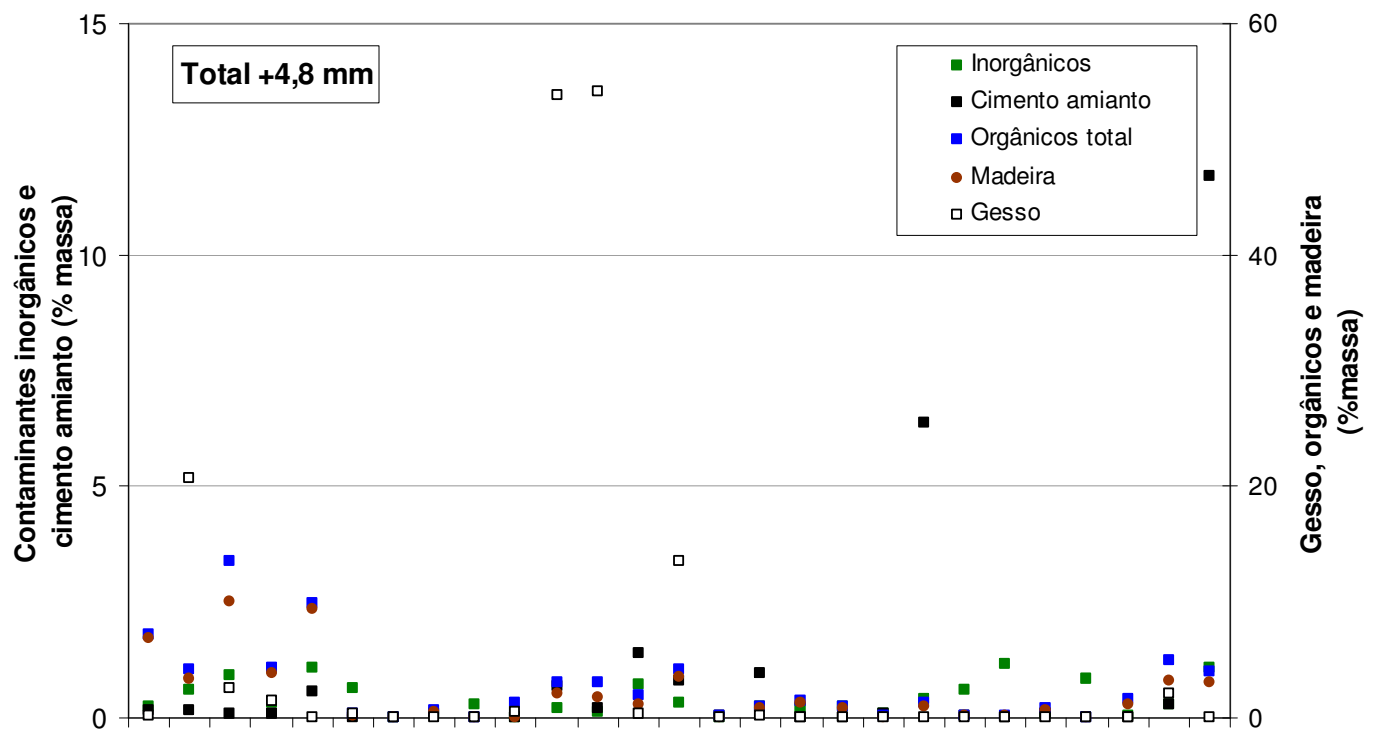

$2355 \quad 91520263033404142464950515457586163656769728084$ Lotes ( $1^{\mathrm{a}}$ amostragem)

Figura 4.41 - Teor de contaminantes dos lotes de RCD da 1르a amostragem, Macaé.

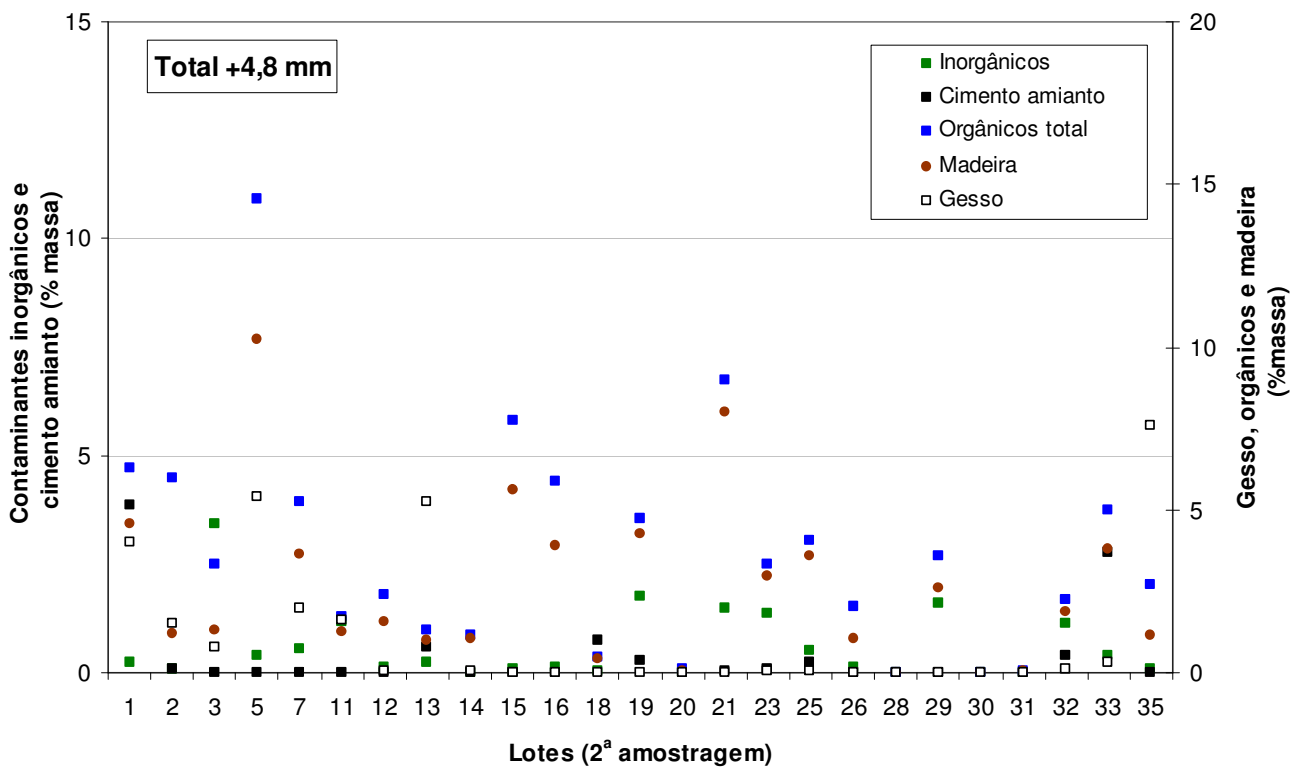

Figura 4.42 - Teor de contaminantes dos lotes de RCD da $2^{2}$ amostragem, Macaé. 


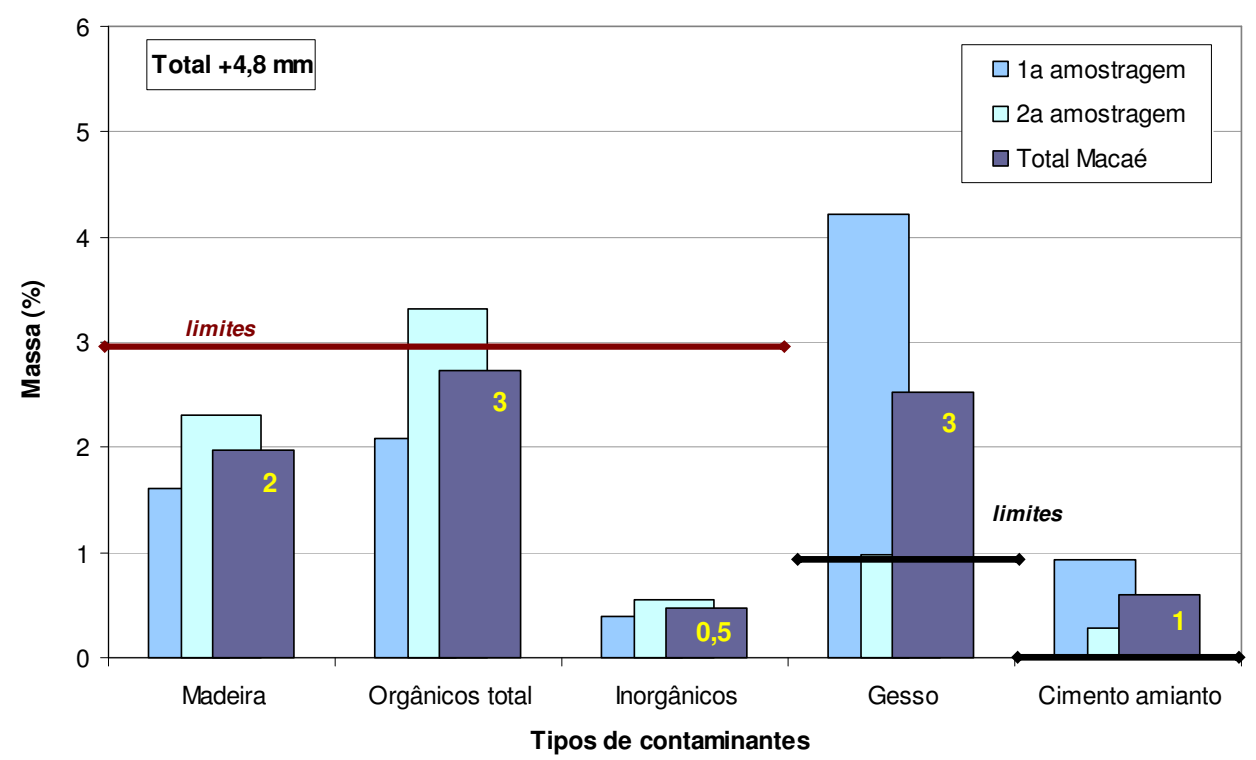

Figura 4.43 - Teores médios de contaminantes e valores limites, Macaé.

No caso dos contaminantes orgânicos, a contaminação depende da fração granulométrica (Figura 4.44). Ela é maior para as frações granulométricas mais grosseiras $(+80,-80+25,4 \mathrm{~mm})$, que está associada à granulometria da madeira presente no resíduo. Os contaminantes mais restritivos para a reciclagem em Macaé são o gesso e o cimento amianto, que, na média dos lotes, tem teores superiores ao sugerido. Eles aumentam na fração mais fina $(<25,4 \mathrm{~mm})$, onde a catação se torna menos eficiente.

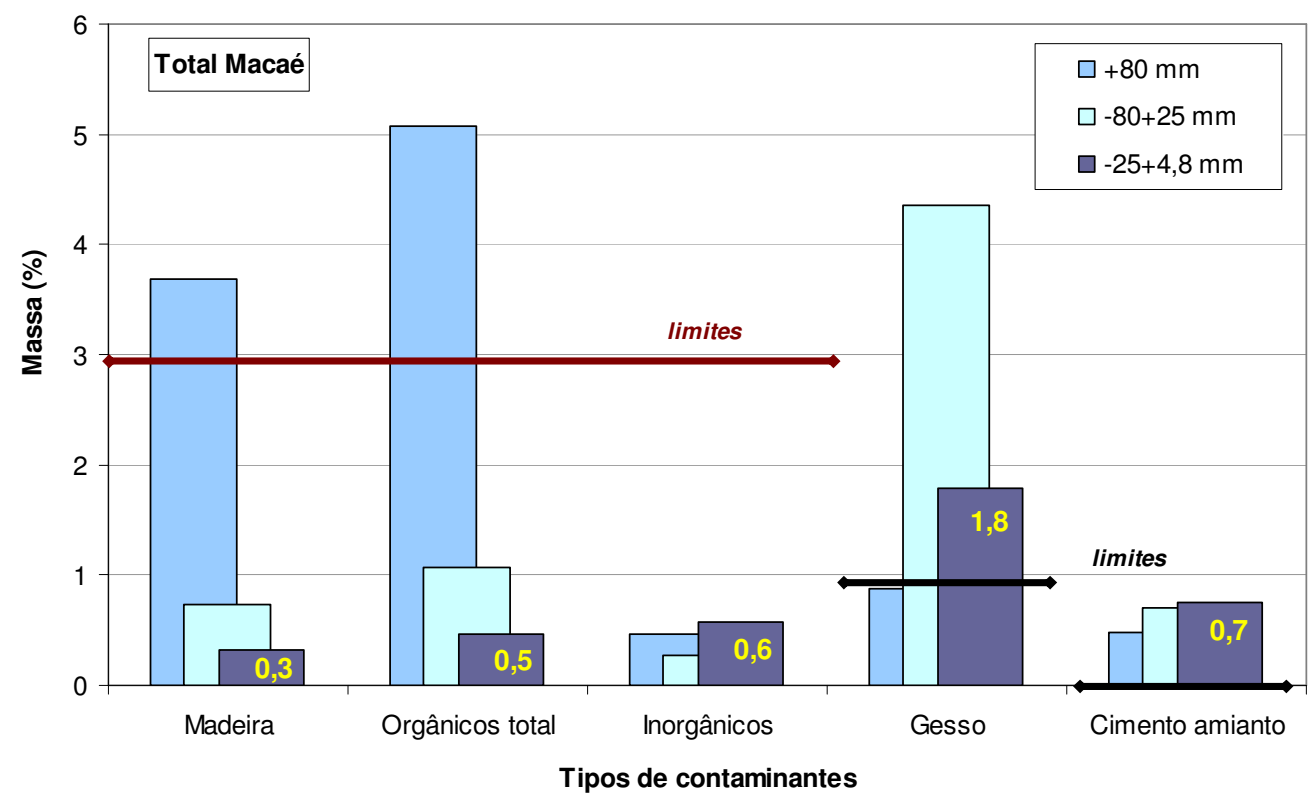

Figura 4.44 - Contaminantes por intervalo granulométrico, Macaé. 
Somente $42 \%$ das caçambas apresentaram teores de contaminantes aceitáveis (Figura 4.45 ). Nos $58 \%$ das caçambas remanescentes, os seguintes contaminantes estão presentes em ordem de importância: a) orgânicos (24\%), cimento amianto (19\%) e gesso (15\%).

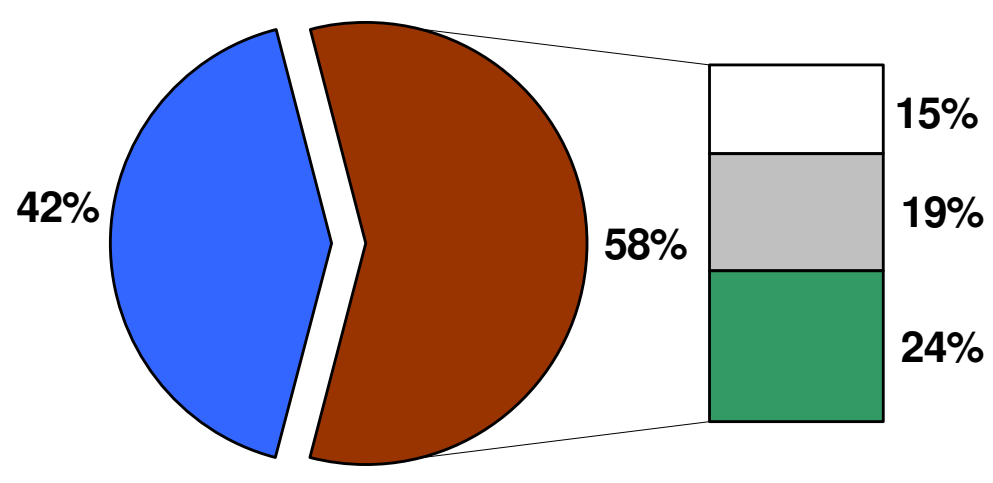

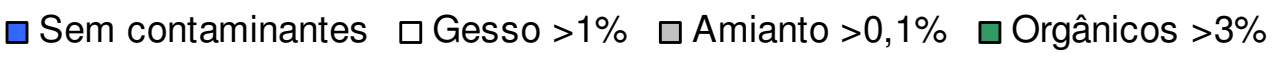

Figura 4.45 - Distribuição de contaminantes nos lotes de Macaé.

Embora a produção de contaminantes nas amostras de São Paulo seja bastante reduzida em relação à Macaé, somente $46 \%$ das caçambas apresentaram teores de contaminantes aceitáveis. Nos $54 \%$ dos demais lotes foram identificados os seguintes contaminantes, em ordem de importância: a) cimento amianto (46\%), orgânicos e gesso ( $4 \%$ cada), evidenciando a elevada contaminação de cimento amianto do resíduo de São Paulo, e que por isso é necessário adotar um controle de qualidade mais rigoroso para tal parâmetro.

A contaminação por fração granulométrica indica que a madeira está predominantemente concentrada na fração granulométrica mais grossa, enquanto que os inorgânicos e o cimento amianto estão preferencialmente na fração -25,4 $+4,8 \mathrm{~mm}$. O gesso, por sua vez, aumenta paulatinamente para as frações mais finas. 
4.15 DISTRIBUIÇÃO DE DENSIDADE, MASSA ESPECÍFICA APARENTE, ABSORÇÃO DE ÁGUA

\subsubsection{Macaé}

A Figura 4.46 apresenta a variabilidade da distribuição de densidade dos agregados graúdos $(-25,4+4,8 \mathrm{~mm})$ dos lotes da cidade de Macaé, para os dois principais intervalos $(d<1,9 ; d>2,2)$. Os teores são bastante variáveis - de 0 a $80 \%$. Na média (Figura 4.47) é observada a presença mais expressiva do produto de menor densidade $(\mathrm{d}<1,9)$, seguida do produto intermediário $(1,9<\mathrm{d}<2,2)$. A presença do produto mais denso, que é o mais indicado para o emprego como agregado em concreto, foi baixa (cerca de 16\%).

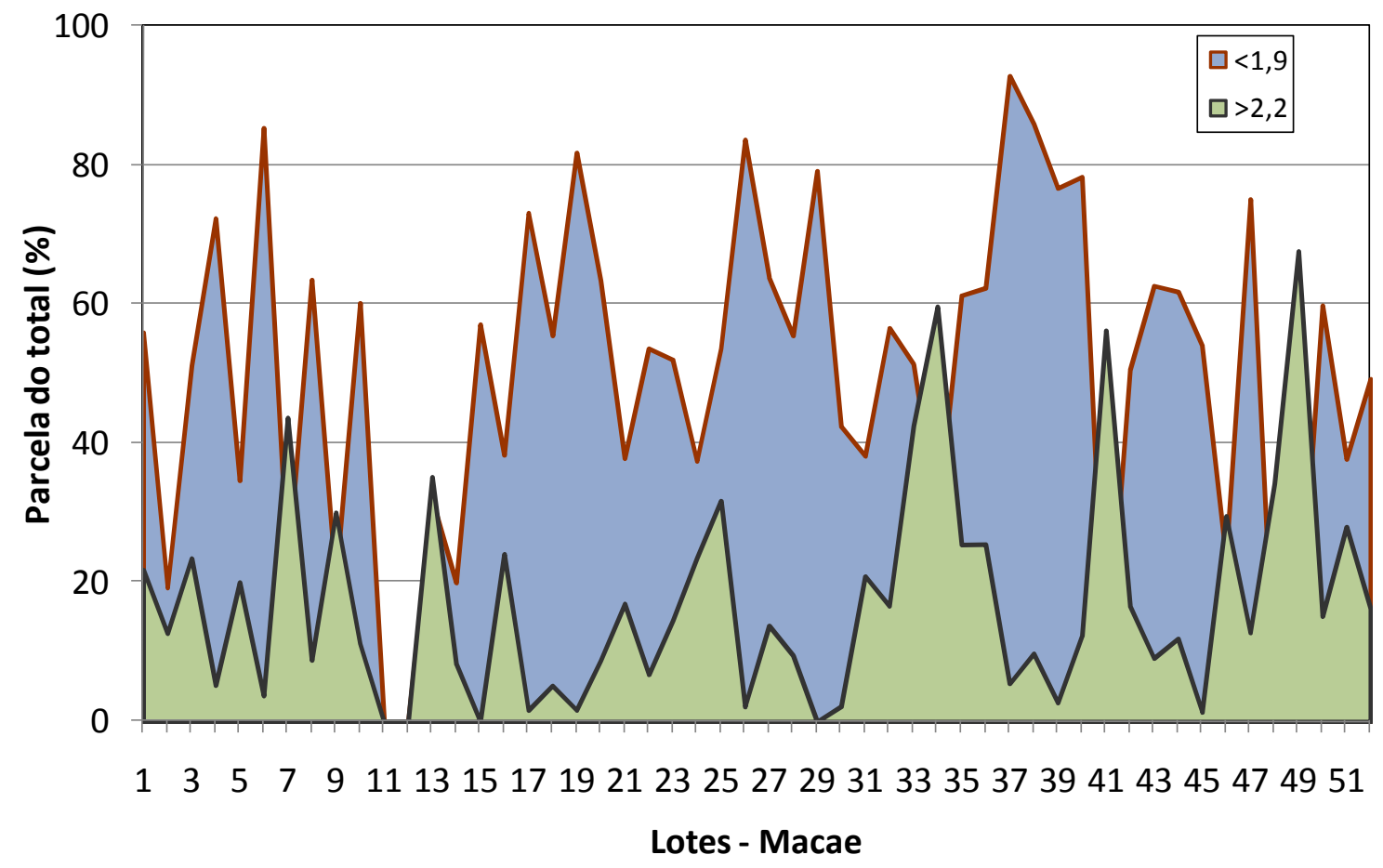

Figura 4.46 - Distribuição de densidade dos agregados graúdos, lotes de Macaé. 


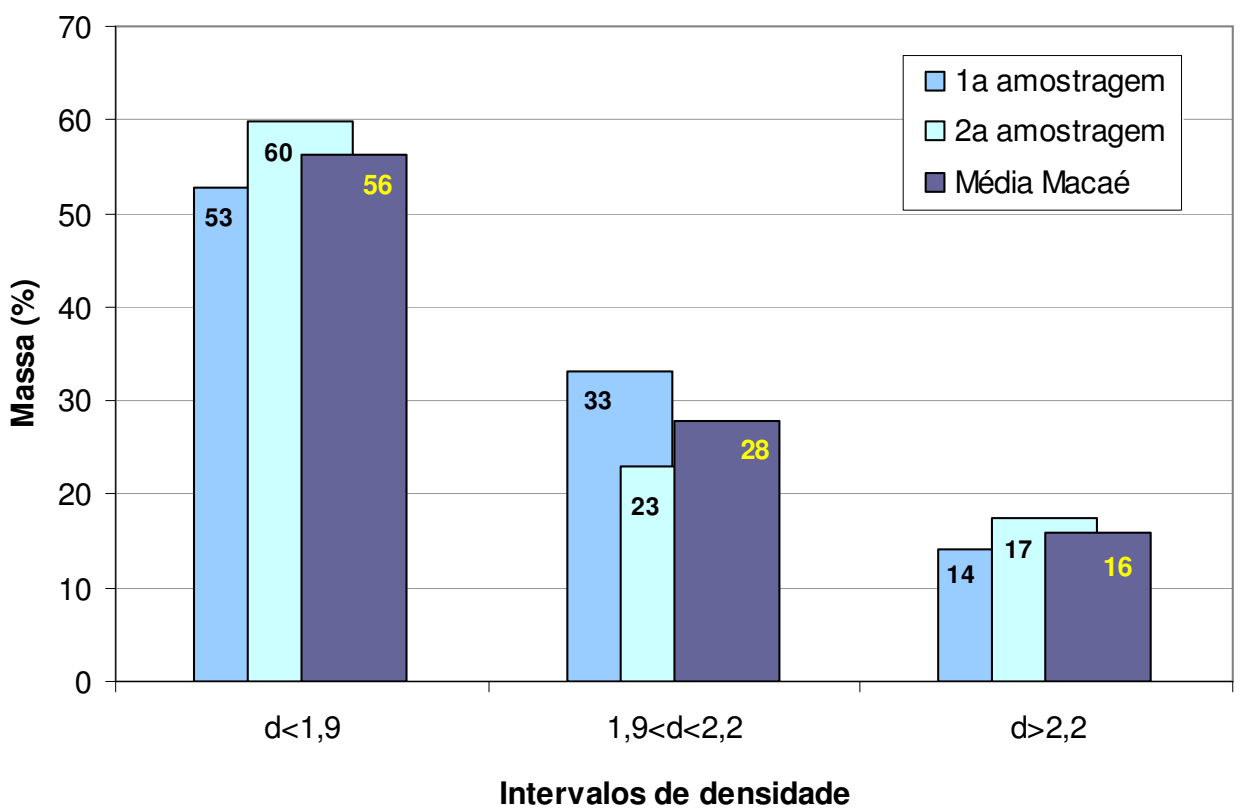

Figura 4.47 - Distribuição média de densidade dos agregados graúdos, lotes de Macaé.

Na cidade de Macaé, 17\% (Figura 4.48) dos lotes têm uma parcela expressiva de material com densidade $d>2,2$ (igual ou superior à densidade do concreto), podendo ser classificado como de qualidade superior em relação aos demais lotes. Os dados evidenciam a pequena presença de lotes homogêneos de concreto.

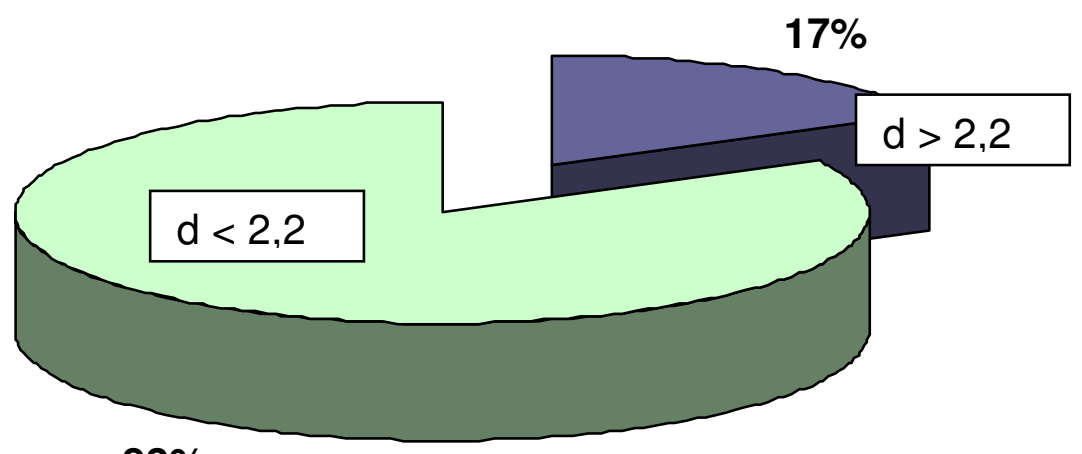

$83 \%$

Alta Qualid. $\square$ Média+Baixa Qualid.

Figura 4.48 - Distribuição dos lotes de alta qualidade dos lotes de Macaé.

\subsubsection{São Paulo}

A Figura 4.49 apresenta a variabilidade da distribuição de densidade dos agregados graúdos $(-25,4+4,8 \mathrm{~mm})$ dos lotes da cidade de São Paulo, para os dois principais intervalos $(d<1,9 ; d>2,2)$. A proporção de material com $d>2,2$ apresenta elevada 
variabilidade, sendo em média; $d>2,2)$. A proporção de material com $d>2,2$ apresenta elevada variabilidade, sendo em média 29\% (Figura 4.50), enquanto que o produto com $d<1,9$ representa em média $53 \%$ da massa total.

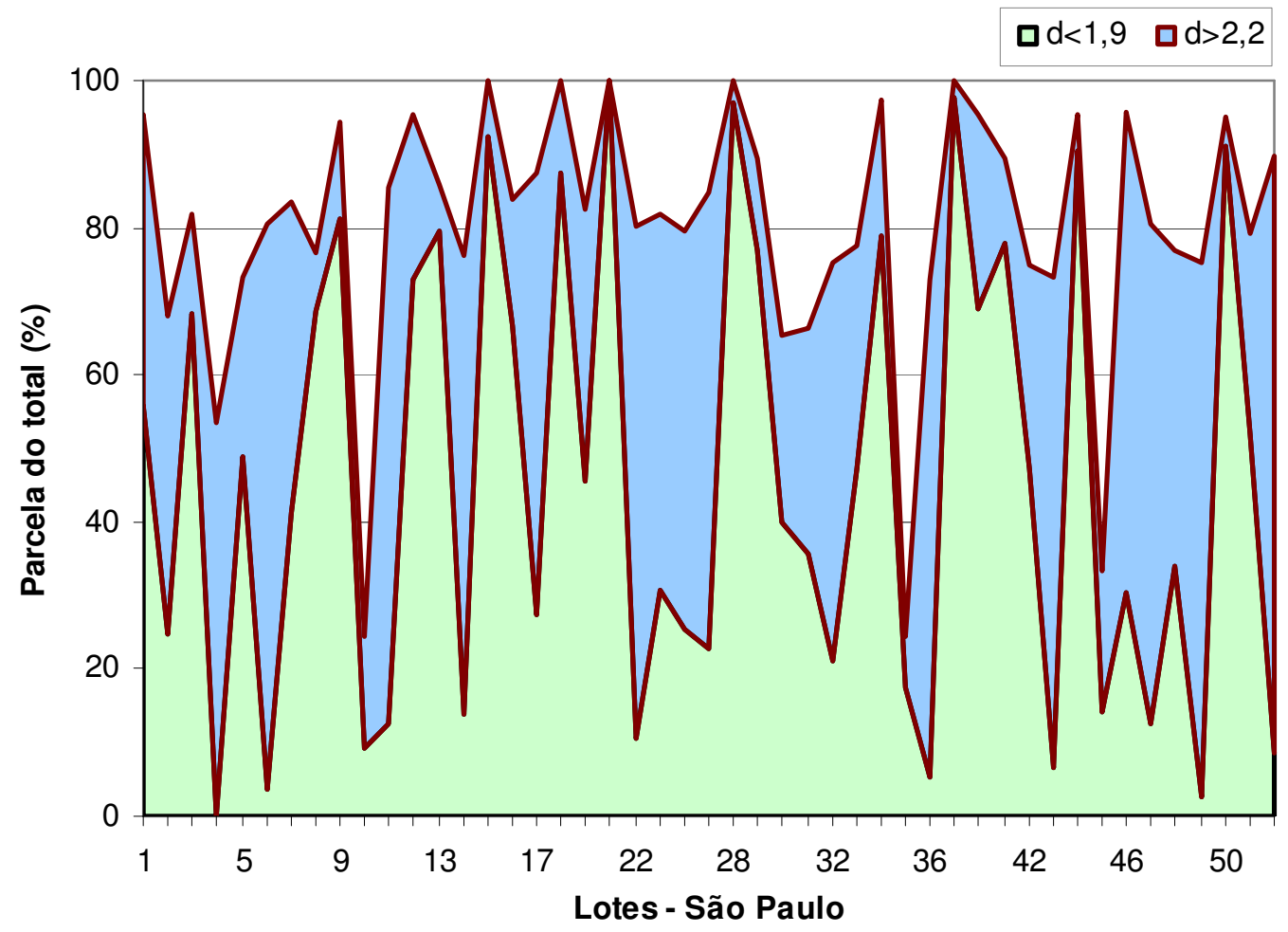

Figura 4.49 - Distribuição de densidade dos agregados graúdos, lotes de São Paulo.

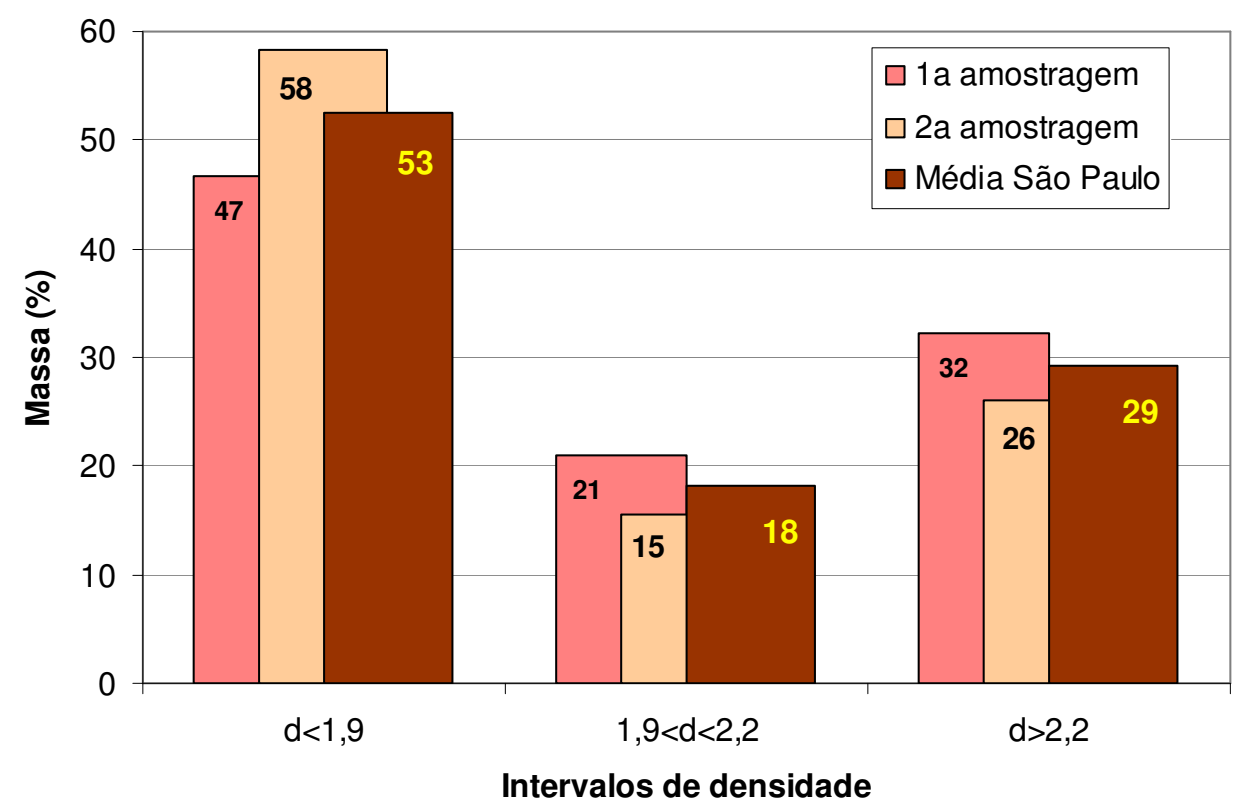

Figura 4.50 - Distribuição média de densidade dos agregados graúdos, lotes de São Paulo. 
Para os lotes de RCD de São Paulo, 49\% (Figura 4.51) apresenta uma parcela expressiva de material com densidade $d>2,2$ (igual ou superior à densidade do concreto), podendo ser classificado como de qualidade superior em relação aos demais lotes. Os dados evidenciam uma expressiva proporção de lotes homogêneos de concreto.

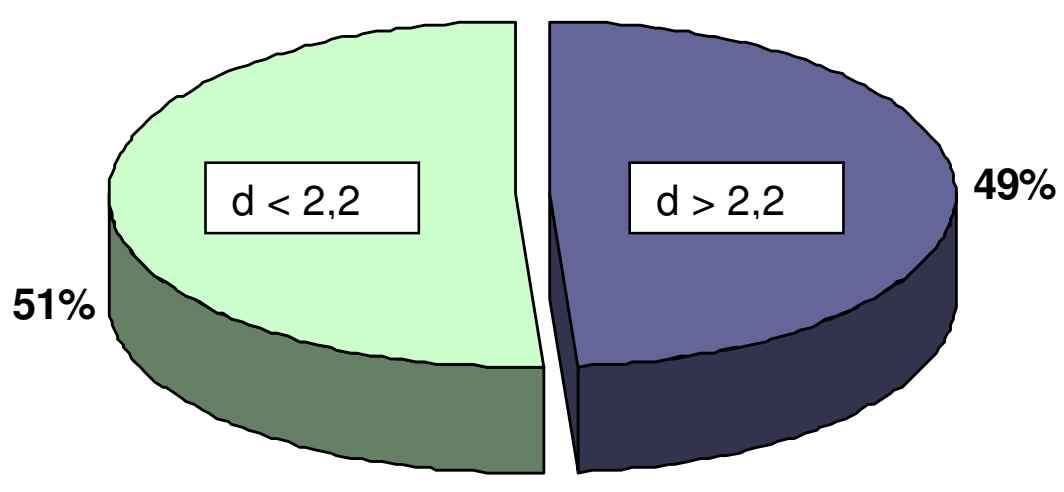

๑ Alta Qualid. \ Média+Baixa Qualid.

Figura 4.51 - Distribuição dos lotes de alta qualidade dos lotes de São Paulo.

A Figura 4.52 apresenta a correlação entre os resultados de massa específica aparente e absorção de água dos produtos de densidade dos agregados gaúchos dos lotes de São Paulo, para as duas amostragens consideradas, indicando novamente que não dependem da origem.

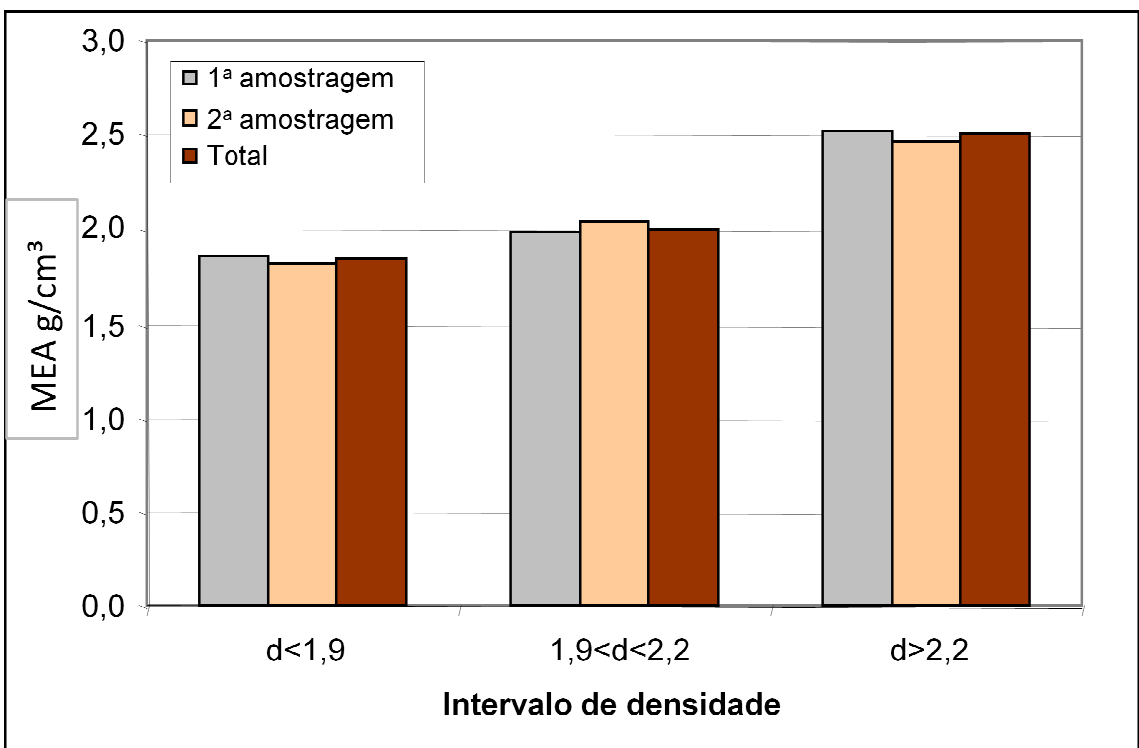

Figura 4.52 - Massa específica aparente $x$ densidade, fração $-25,4+4,8 \mathrm{~mm}$, São Paulo. 
A Figura 4.53 apresenta a variabilidade da distribuição de densidade dos agregados graúdos $(-25,4+4,8 \mathrm{~mm})$ dos lotes da cidade de Maceió, para os dois principais intervalos $(d<1,9 ; d>2,2)$. A proporção de produtos com $d>2,2$ é significativamente menor do que nas demais cidades, bem como é o produto de menor representatividade em massa, apenas 7\% (Figura 4.54), por outro lado o produto $\mathrm{d}<1,9$ representa $69 \%$ da massa total dos lotes caracterizados.

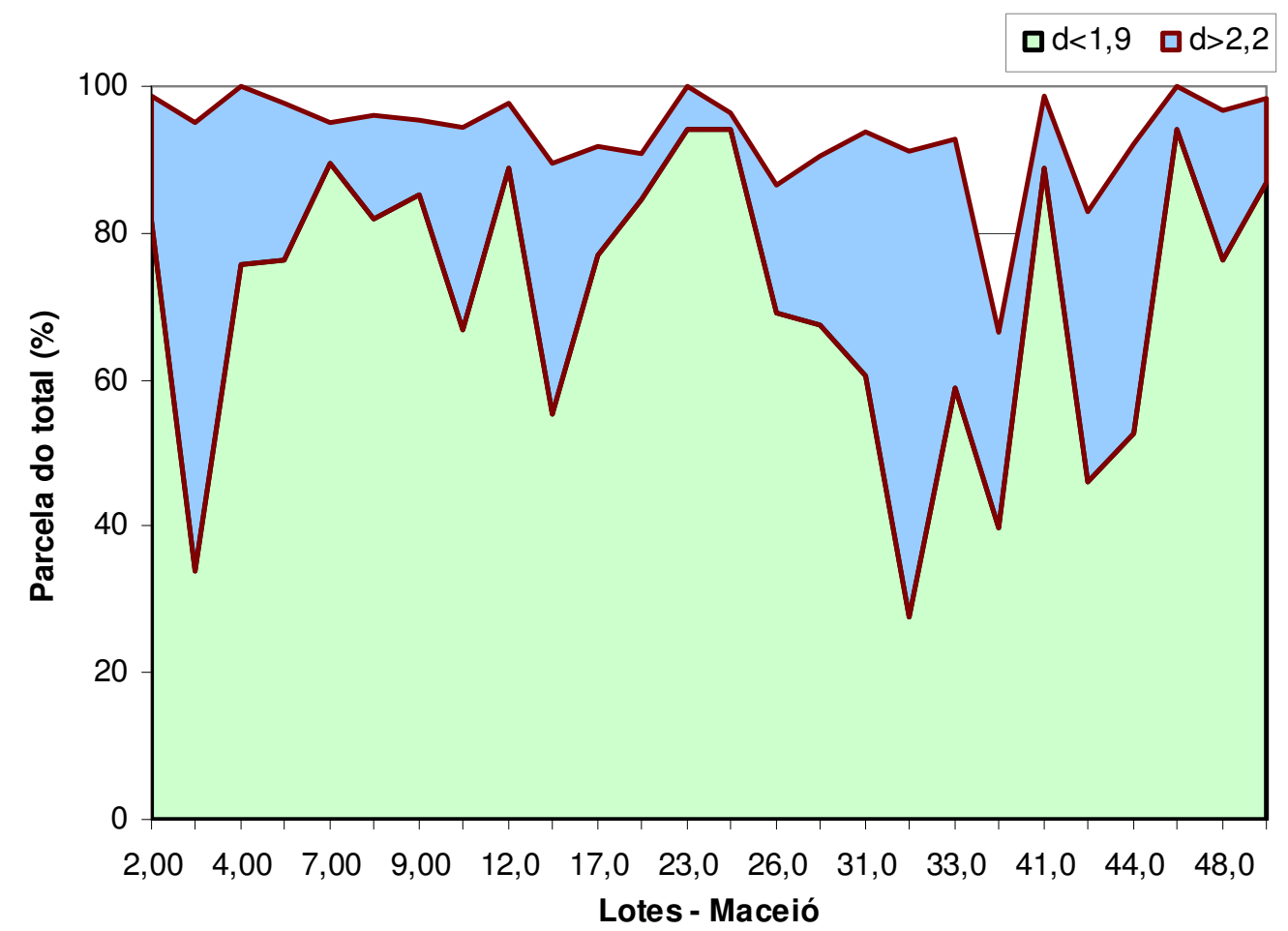

Figura 4.53 - Distribuição de densidade dos agregados graúdos, lotes de Maceió. 


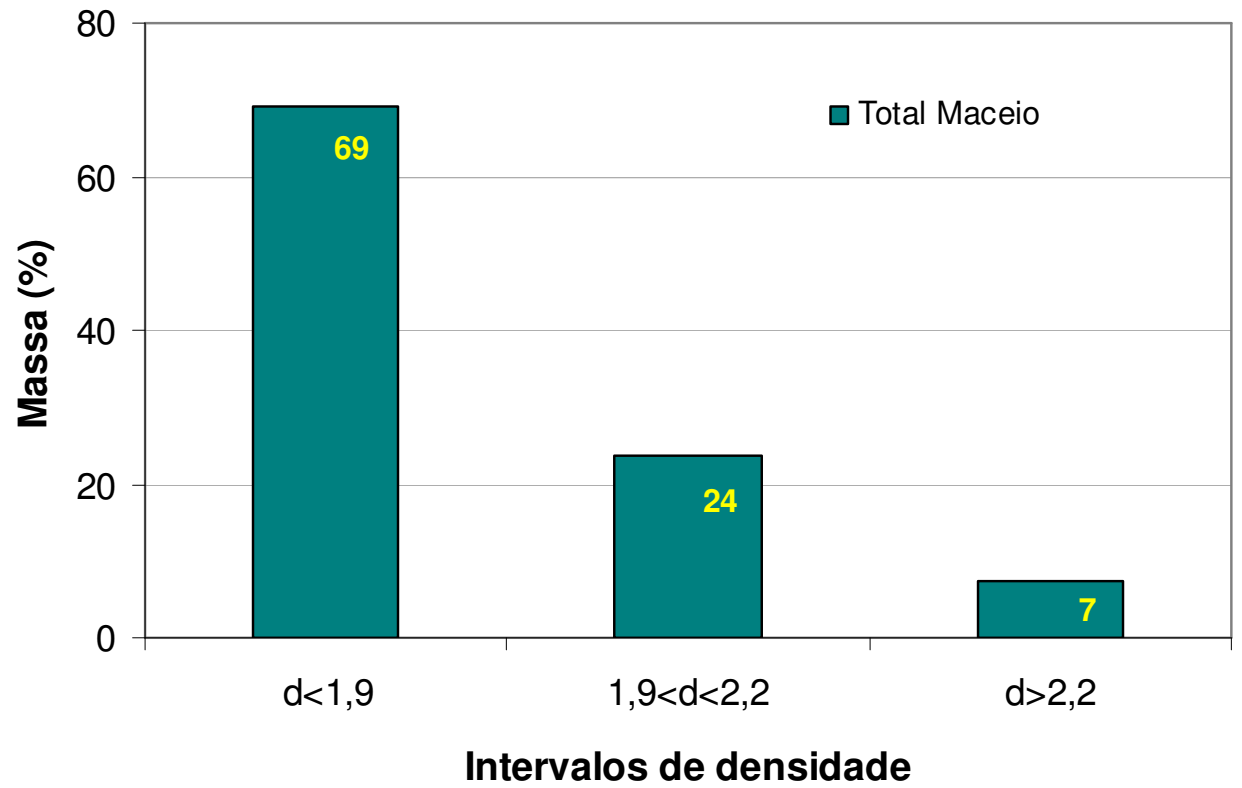

Figura 4.54 - Distribuição de densidade dos agregados graúdos, lotes de Maceió.

Para os lotes de RCD de Maceió, apenas 4\% (Figura 4.55) apresenta uma parcela expressiva de material com densidade $\mathrm{d}>2,2$ (igual ou superior à densidade do concreto), podendo ser classificado como de qualidade superior em relação aos demais lotes. Os dados evidenciam uma pequena parcela de lotes homogêneos de concreto.

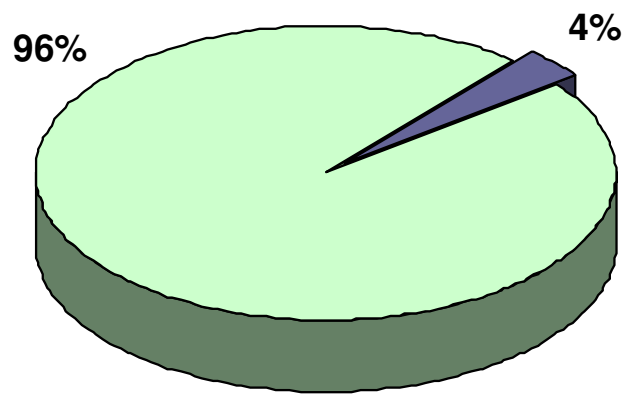

$\square$ Alta Qualid. $\square$ Média+Baixa Qualid.

Figura 4.55 - Distribuição dos lotes de alta qualidade dos lotes de Maceió. 
Resumo das qualidades das três cidades (Figura 4.56) que serão usadas para modelagem
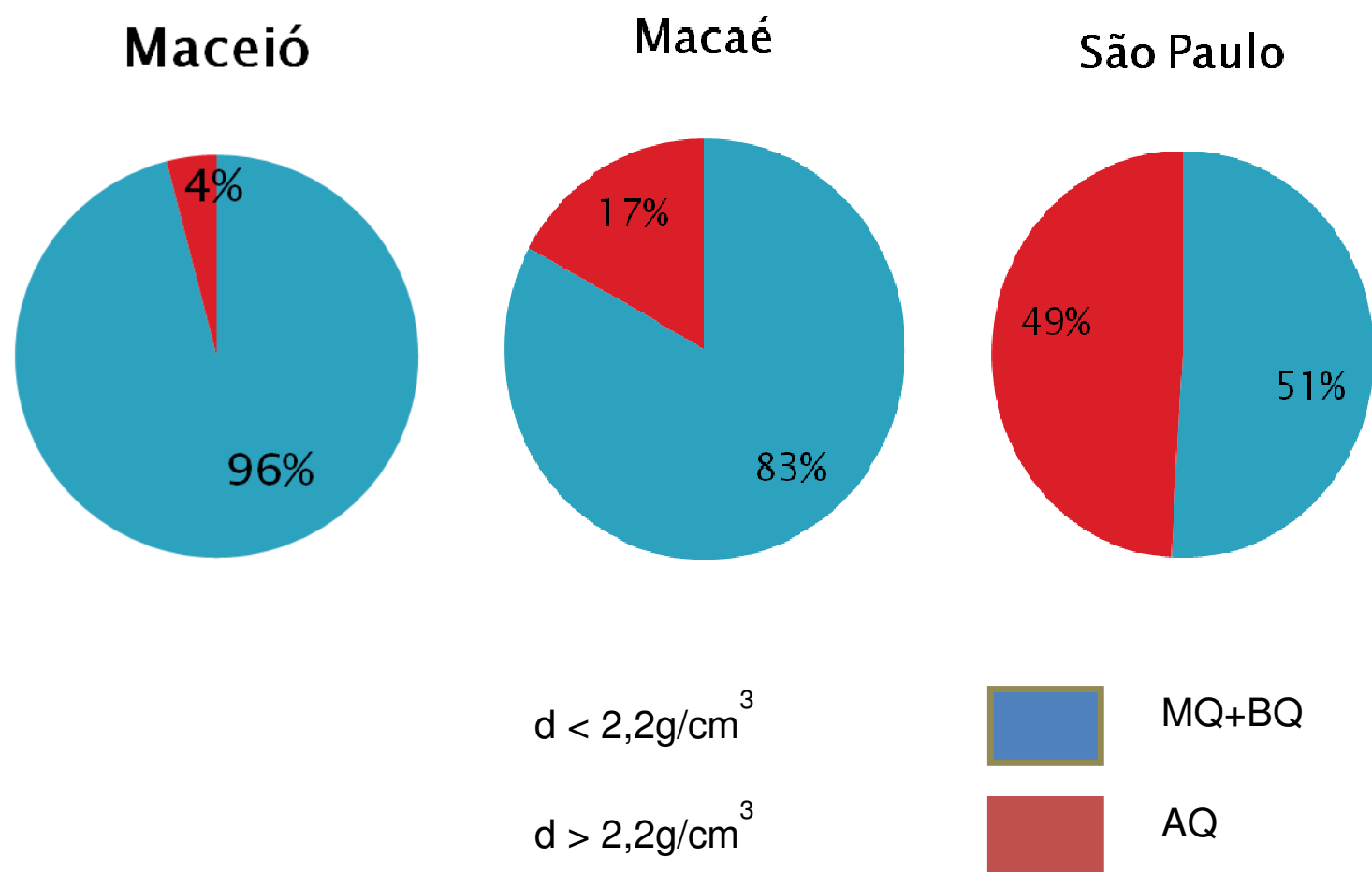

Figura 4.56 - Resumo das qualidades das três cidades

$M Q+B Q$

$A Q$ 


\section{MODELO DINÂMICO PARA GERENCIAMENTO DO RCD NA CADEIA DA CONSTRUÇÃO CIVIL}

"Quelli che si innamorano della pratica senza tener conto della scienza, sono come marinai che entrano nela nave senza timone o bussola e che mai hanno la certezza di dove stanno andando", Leonardo Da Vinci in Pensieri.

"Os que se encantam com a prática sem a ciência são como os timoneiros que entram no navio sem timão nem bússola nunca tendo certeza do seu destino", Leonardo Da Vinci em Pensamentos. 


\subsection{INTRODUÇÃO}

$\mathrm{Na}$ última década, uma série de trabalhos sinalizavam o potencial econômico do resíduo de construção, utilizando modelos estáticos para o planejamento e a viabilidade da reciclagem em municípios brasileiros. Neste período houve a mudança do marco regulatório e o nascimento de um mercado para agregados reciclados. Este movimento tanto aumentou como tornou mais complexas as atividades do gerenciamento dos resíduos de construção e demolição.

Os modelos que serão apresentados foram extraídos do que realmente existe no gerenciamento de resíduos na realidade brasileira. Refere-se às inter-relações dos agentes quer seja do sistema público de limpeza ou das empresas privadas que atuam produzindo bens e serviços neste segmento da construção civil. Igualmente as fontes de matéria-prima foram as cidades amostradas que nos forneceram dados do entulho médio úteis para o modelo de custo benefício da cidade, bem como os produtos da reciclagem que são comercializados no mercado de agregados reciclados.

Por sua vez, a mudança do marco regulatório como o princípio do poluidor pagador e da responsabilidade compartilhada dentro do ciclo do produto, torna imperativo o emprego de instrumentos econômicos como subsídios, isenções de impostos, bem como a procura pela transparência sobre o agente poluidor, além do quantitativo dos custos do gerenciamento do sistema.

O conjunto dos dados qualitativos dos resíduos e das operações para redução, reuso e reciclagem (3R's) dos mesmos, os circuitos das plantas de reciclagem e as qualidades dos agregados reciclados, os custos de transporte nas várias atividades requerem a técnica da modelagem dinâmica para estudar o problema e propor soluções. Sabemos que não existe um modelo único para atividades complexas, mas não há melhor representação da realidade para o gerenciamento do que esta técnica.

O conceito de sistemas dinâmicos (SD) foi introduzido por Jay Forrester, em 1958 no MIT. Baseado no System Thinking, SD permite analisar o comportamento e interrelações das variáveis de um sistema de maneira dinâmica. Possui uma natureza 
qualitativa (soft) e quantitativa (hard), que, respectivamente, identifica relações circulares de causa-efeito e desenvolvem modelos de simulação. Dessa forma, SD podem ser usados para compreender melhor o comportamento dos sistemas e identificar a melhor maneira de operá-lo.

Através do princípio de causa-efeito, em função do tempo e das experimentações virtuais, é possível identificar os impactos de certas decisões no sistema.

Há variáveis que se comportam como estoques, fluxos, conectores e conversores, ilustrados na Figura 5.1. Os estoques representam os acúmulos no sistema, cuja variação depende dos fluxos de entrada e de saída, casos existentes, representados pelas válvulas. Os conversores são usados para auxiliar nas equações que determinam as relações entre as variáveis, que precisam estar conectadas através dos conectores (as setas), simbolizando as relações de causa-efeito.

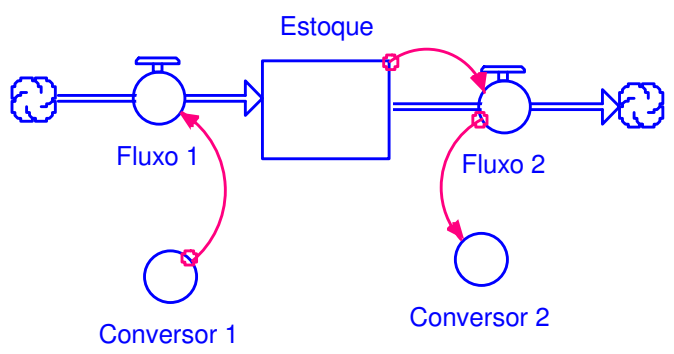

Figura 5.1 - Elementos básicos na modelagem de sistemas dinâmicos.

O software iThink é uma ferramenta para estruturação de processos ou estratégias associadas dinamicamente, muito aplicável no setor de construção. Possui uma interface de simples compreensão. Na condição de software de modelagem dinâmica, possibilita a criação de ciclos "virtuosos" ou "viciosos" para o sistema, bem como o uso de gráficos para acompanhamento dos valores das variáveis, bastante utilizados como ferramentas para simulação de cenários desejados.

A metodologia da modelagem dos sistemas segue cinco etapas segundo Zhao et al.(2006), representadas pela Figura 5.2.

1. A primeira etapa consiste em definir o objetivo, na escolha dos fatores relevantes, dos limites da abordagem, do horizonte de planejamento e do comportamento esperado do sistema; 
2. Desenvolver uma hipótese dinâmica a partir dos ciclos de feedback e dos elementos básicos;

3. Simulação do modelo;

4. Testes e avaliação do resultado. Testar a viabilidade da estrutura do modelo. Essa etapa é importante para avaliar a sensibilidade e o nível de esforço para tornar as variáveis mais precisas.

Ao atingir maior confiança no modelo, o desenho do modelo e as análises de cenários pelos gráficos serão a última etapa.

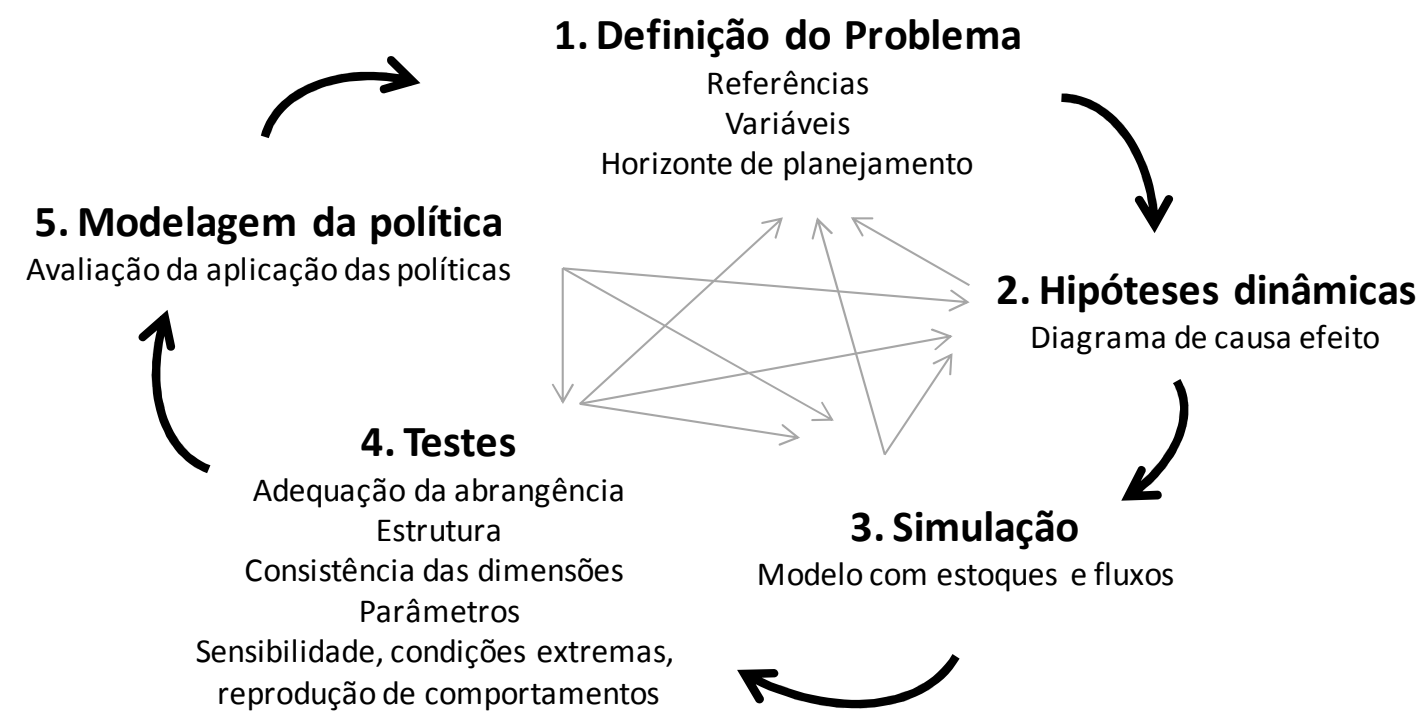

Figura 5.2 - Modelagem como um processo interativo.

Fonte: Adaptado de Zhao et al. (2006).

Seguindo essa metodologia, foram realizadas duas aplicações de modelagem de sistemas dinâmicos para compreender melhor o ciclo de vida do RCD e as diferentes operações nas plantas de reciclagem, mostrados nos próximos tópicos.

\subsection{APLICAÇÕES DO SISTEMA DINÂMICO (SD)}

Este tópico tem como objetivos mostrar as inter-relações no gerenciamento de RCD, bem como analisar o custo-benefício entre diferentes cenários que possibilitem a 
viabilidade econômica dos centros de reciclagem. Foram propostos dois modelos baseados em Sistema Dinâmico através do software de simulação iThink que permitem analisar a complexidade da cadeia de gerenciamento de RCD em seu ciclo de vida, bem como sua viabilidade econômica, o tipo de planta mais adequado, considerando a composição do RCD da cidade.

Segundo Duran et al. (2006), a fim de incentivar a reciclagem aos geradores e estimular a formação de mercado de reciclado, duas esferas devem ser consideradas e representadas esquematicamente na Figura 5.3. A primeira é a esfera dos consumidores de agregados, sejam eles construtoras, reparadoras ou Prefeitura. De acordo com os custos de aquisição envolvidos na compra de agregados, como transporte e preço de venda da tonelada, os consumidores optarão por agregados naturais ou reciclados; já a segunda esfera é a dos geradores de resíduos como empresas de demolição e os próprios consumidores citados, que optarão pelo descarte dos resíduos em plantas de reciclagem ou em aterros sanitários, de acordo com os custos envolvidos.

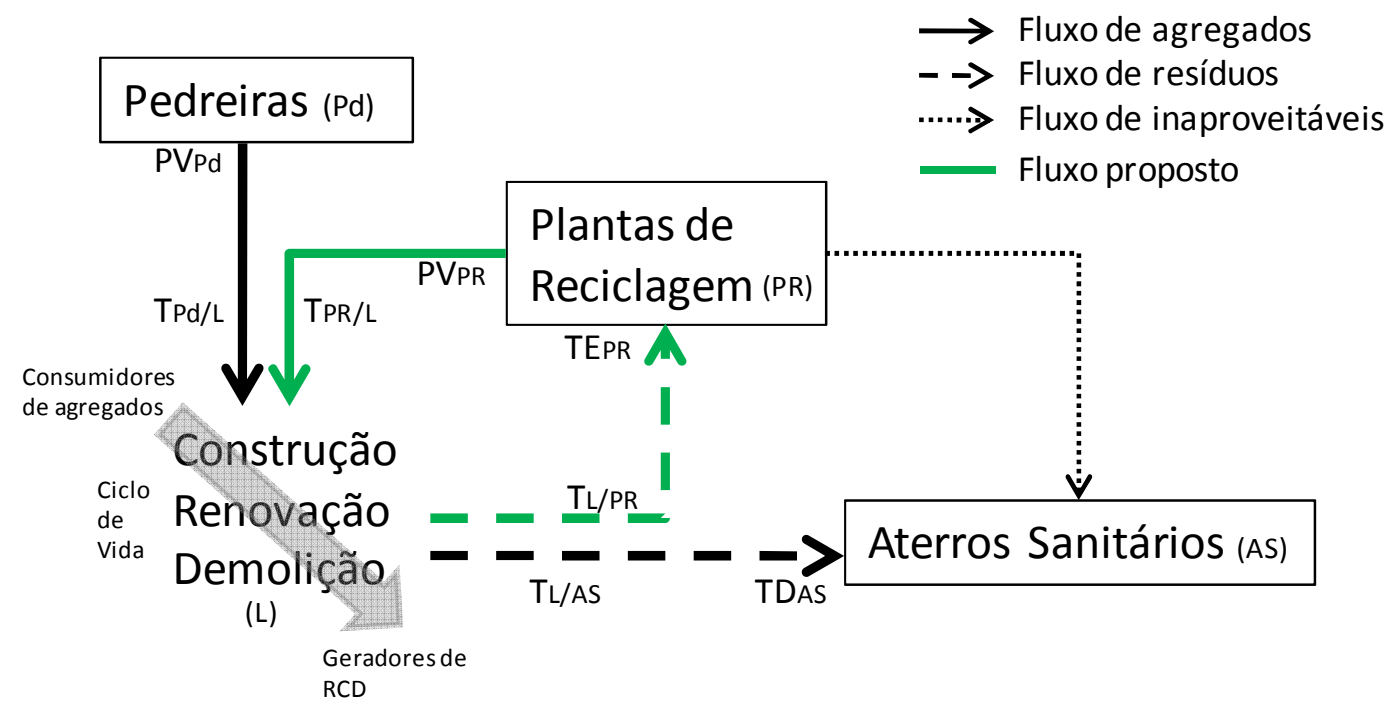

Figura 5.3 - Ciclo simplificado de consumo e descarte de agregados na Construção Civil.

PVPd - Preço de venda após extração/beneficiamento de 1ton de agregados nas Pedreiras

PVPR - Preço de venda após beneficiamento de 1ton de agregados reciclados na Planta de Reciclagem 
TPd/L - Custo de transporte de 1ton da Pedreira para o local de construção ou renovação

TPR/L - Custo de transporte de 1ton de reciclados da PR para o local de construção ou renovação

$T L / P R-C u s t o$ de transporte de 1 ton de entulho de $L$ para o $P R$

TL/AS- Custo de transporte de 1ton de entulho de L para o AS

TEPR - Taxa de entrada por tonelada descartada na Planta de Reciclagem

TDAS - Taxa de descarte por tonelada descartada no Aterro Sanitário

Considerando que as especificações técnicas do agregado reciclado para determinada operação atendem aos mesmos requisitos que as do agregado natural equivalente, o único fator que os consumidores terão de comparar é o custo de aquisição (custo unitário da tonelada e o custo do transporte da tonelada até o local de operação) e optar pelo que cobrar o menor preço final. Por isso, os custos em uma Planta de Reciclagem devem ser menores do que os de uma Pedreira, equação (1).

$$
P V_{P R}+T P R / L<P V P d+T P d / L
$$

Já os geradores de resíduos deverão comparar os custos de descarte na PR com os custos de depósitos em aterros. Somados o custo de transporte à planta com a taxa de depósito, este resultado deve ser menor do que os preços cobrados pelos aterros, equação (2).

$$
T L P R+T E P R<T L / A S+T D A S
$$

Essas equações são importantes, pois um modelo de sistema dinâmico assume alguns pressupostos e hipóteses de causa e efeito entre as variáveis analisadas. Em cada sistema é preciso estabelecer como são essas inter-relações para definir o escopo da questão a ser analisada. Diante disso, nos dois modelos foram consideradas as seguintes condições:

Custo de transporte: como as distâncias entre as fontes geradoras de RCD para os centros de reciclagem e aterros sanitários variam muito dentro da cidade, considerou-se que as distâncias seriam as mesmas $(30 \mathrm{~km})$, assim como os custos 
com transporte $(1,00 \mathrm{R} \$ / \mathrm{km} \times 30 \mathrm{~km} / \mathrm{t}=30,00 \mathrm{R} \$ / \mathrm{t})$ em ambos os casos para facilitar as análises. Ou seja, $T P d / L=T P R / L=T L / P R=T L / A S$. Por isso, a taxa de entrada na planta de reciclagem deverá ser menor do que a taxa de entrada no aterro. Nos dois modelos foi considerada $R \$ 1,00$ a diferença. Ou seja, se a taxa de entrada no aterro for de $\mathrm{R} \$ 6,00 / \mathrm{t}$, isso significa que a taxa de entrada na planta de reciclagem é $\mathrm{R} \$ 5,00 / \mathrm{t}$.

Nesse ponto é importante a atuação de políticas que controlem e mantenham o preço de entrada nos aterros elevados ao máximo a fim de incentivar a reciclagem, mas não tanto que possam influenciar o descarte ilegal. Essa dinâmica e relação de causa-efeito entre o preço e a ilegalidade serão tratadas mais adiante.

Horizonte de planejamento: foram coletados dados da construção civil e plantas de reciclagem em cidades no Brasil e no mundo. Foram estudados para um horizonte de 20 anos compreendido entre 2012, data de conclusão da pesquisa, até 2032.

Receitas: os preços de venda dos agregados reciclados ainda são limitados pela insegurança a respeito da sua qualidade técnica e início de um novo mercado. Por isso, são vendidos a $70 \%$ do preço dos equivalentes naturais.

Aumento de preço ao longo dos anos: considerou-se que todos os preços seguirão uma média de crescimento gradiente de $1 \%$ ao ano do seu valor. Ou seja, tanto os preços de venda de agregados naturais e reciclados como custos unitários operacionais fixos e variáveis aumentarão nessa proporção, simbolizando a inflação.

\subsection{MODELO 1: ANÁLISE CUSTO-BENEFÍCIO}

O gerenciamento dos resíduos compreende um conjunto de atividades desde a redução da geração do $\mathrm{RCD}$, sua coleta, seu reuso, reciclagem e o descarte, que apresentam custos determinados para cada fluxo bem como para a armazenagem destes materiais.

O objetivo deste tópico é desenvolver um modelo baseado em Sistemas Dinâmicos que demonstre estas inter-relações e complexidade das atividades do 
gerenciamento de RCD, bem como uma análise do custo-benefício entre três diferentes cenários de preço de entrada na planta de reciclagem que possibilitem a melhor viabilidade econômica destes projetos. Primeiramente, a cidade de Macaé foi utilizada como base, pois se realizaram os experimentos já descritos neste trabalho. Posteriormente, serão comparados os resultados com as outras duas cidades. A estrutura do modelo é representada na Figura 5.4, cujas legendas são ilustradas logo em seguida. 


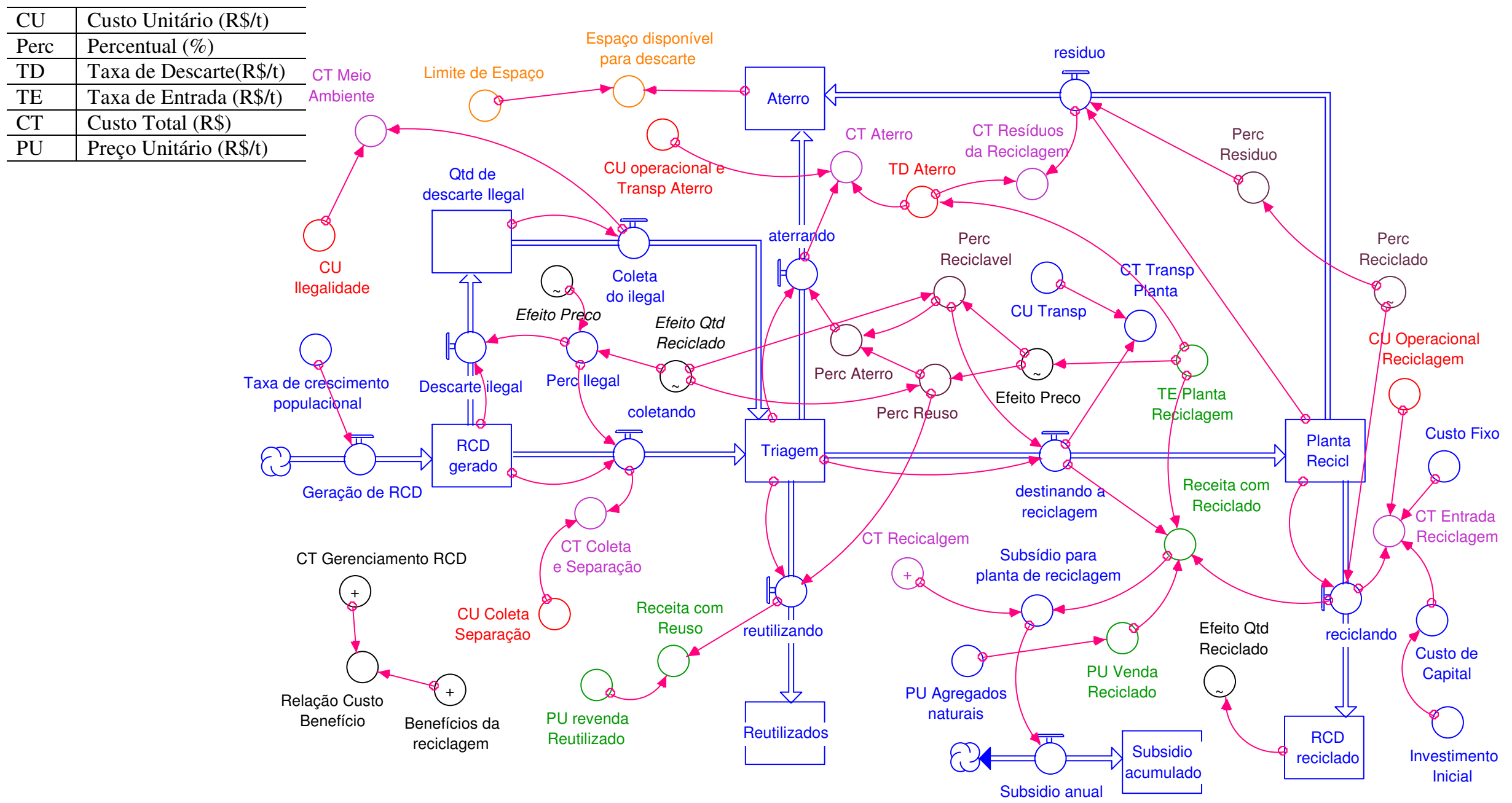

Figura 5.4 - Modelo dinâmico 1 para análise de custo-benefício da reciclagem nas cidades 


\subsubsection{Variáveis analisadas}

Para a análise foram consultados dados operacionais e financeiros relativos a plantas de reciclagem e construtoras no Brasil, principalmente nas cidades de Americana, em São Paulo e Macaé, no Rio de Janeiro. Em Americana foi consultada a empresa SOLOS Reciclagem da Construção ${ }^{10}$. Realizou-se, também, uma revisão bibliográfica sobre análises de custo-benefício e modelagens dinâmicas no setor de reciclagem, principalmente na China, que serão citadas ao longo do trabalho.

Neste modelo foram considerados quatro fases do gerenciamento do RCD:

1. Geração do resíduo na cidade;

2. Coleta, separação e classificação do RCD;

3. Reuso e Reciclagem;

4. Disposição final do RCD.

\subsubsection{Geração de RCD}

A quantidade de RCD gerada em uma cidade é uma variável difícil de ser medida. Estudos como de Pinto (1999) feitos com amostragens em diferentes cidades, mostraram uma taxa de geração média anual de RCD no Brasil de cada cidade de 0,5t/hab-ano. Essa referência também é utilizada por Müller para mostrar que a taxa de geração em cada país pode estar relacionada à sua densidade populacional (hab/km²), de acordo com a Figura 5.5.

\footnotetext{
${ }^{10} \mathrm{~A}$ Solos foi visitada em diferentes períodos do trabalho. Essa empresa pertence à construtora Cemara de Americana -SP. Sua razão social antes era Cemara Pró Ambiental.
} 


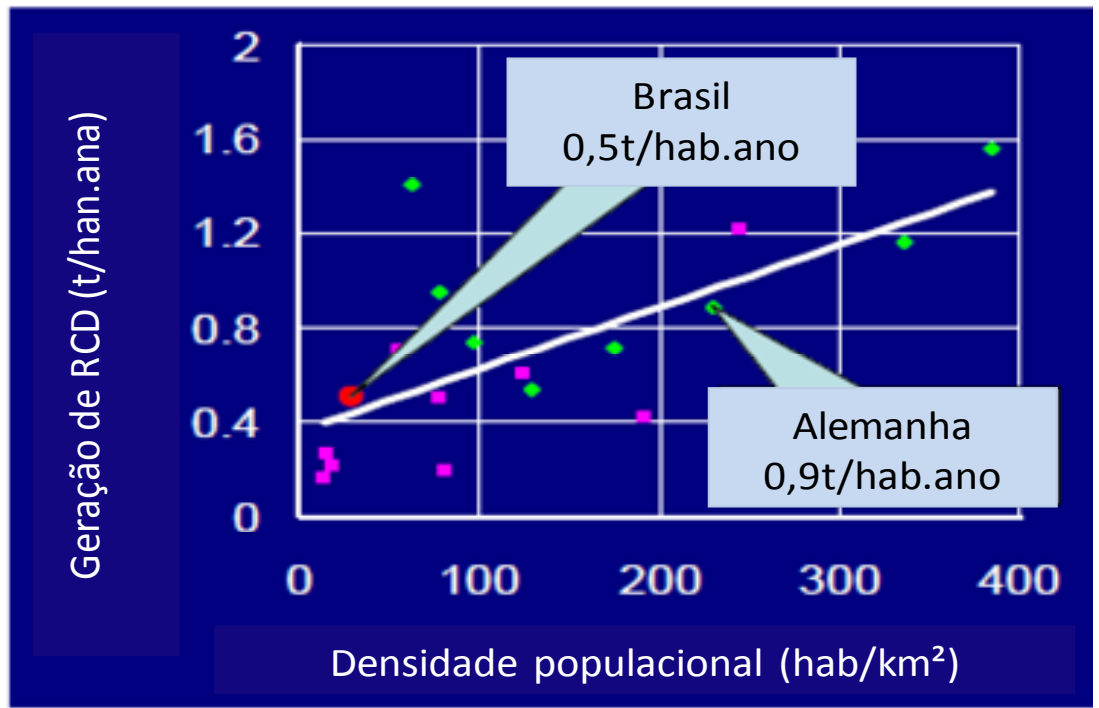

Figura 5.5 - Densidade populacional como a maior influência na quantidade de RCD gerada em cada região.

Fonte: Muller (2012).

$\mathrm{Na}$ cidade de Macaé, com 206 mil habitantes e uma área de 1.200 km² (IBGE, 2011) ou aproximadamente $170 \mathrm{hab} / \mathrm{km}^{2}$, estima-se, pelo gráfico de Müller, uma geração de 0,8 t/hab-ano ou 160 mil t/ano. Já pelo padrão de Pinto, este número seria 100 mil t/ano. Quando em cidades muito populosas como São Paulo, este número estimado pela densidade populacional se torna muito elevado, destoando da realidade.

O número de habitantes nesta cidade duplicou nos últimos 20 anos, com uma maior aceleração nos últimos cinco anos, diferença de $4 \%$ com relação ao anterior. Devido às condições locais de investimento no setor de petróleo e urbanização da região, estimou-se manter essa taxa de crescimento e chegar a 350 mil habitantes em 2032, aumentando a demanda por residências e construções para a ampliação da cidade. Por isso, foi definida para as simulações uma média de crescimento populacional simples de 3\% ao ano sobre a geração inicial de resíduo de 100 mil t/ano.

Além disso, como o Brasil, no período a ser analisado, passará por grandes eventos internacionais como Olimpíadas, Copa do Mundo e programas de desenvolvimento econômico como o PAC 1, PAC 2 ou Minha Casa Minha Vida, essa taxa condiz com o crescimento do índice nacional da construção civil com média de 8,6\% anuais desde 2002 (FGV). 


\subsubsection{Coleta e separação do RCD}

Em grande parte das cidades no Brasil, os resíduos gerados de construções, reformas e demolições são coletados in loco da geração e transportados para centros de triagem, onde serão separados segundo suas composições, uso e destino de cada resíduo. Este processo envolve, portanto, custos de coleta, separação e transporte.

\subsubsection{Reuso e reciclagem do RCD}

Após a coleta e classificação nos centros de triagem, os resíduos triados podem interessar a algumas empresas que desejem reutilizá-los ou ainda necessitar ser processados em plantas de reciclagem para atingir melhores características para diferentes utilizações. Tanto o reuso direto como a reciclagem representam a logística reversa da construção civil, com custos em suas etapas. No primeiro caso, para efeitos de simplificação, os consumidores dos resíduos que serão reutilizados serão os responsáveis por arcar com os custos de transporte ou mesmo reutilizar no próprio local onde houve geração de RCD.

Outra parte do RCD é destinada à planta de reciclagem, onde haverá o custo operacional de reciclagem, de descarte de resíduos do processo nos aterros, transporte, bem como os custos de capital, variável esta que depende do capital inicial investido (aquisição do terreno, licenças, equipamentos envolvidos, construção da planta e outros).

\subsubsection{Destinação final do RCD}

Popularmente conhecidos como "lixões", os aterros" atualmente no Brasil representam o destino mais comum do RCD. Os custos envolvidos no processo de descarte no aterro, tanto a partir da triagem ou a partir da reciclagem, são a taxa de entrada no aterro, custo de transporte e o de operação do aterro. Além disso, um importante fator a ser considerado é o seu espaço disponível para descarte, uma vez que há um volume de ocupação máximo e no caso de se atingir a saturação, obriga-se serem feitas novas aquisições de terrenos pelas municipalidades,

\footnotetext{
${ }^{11}$ Existem 3 tipos de aterro: aterro sanitário, aterro controlado e os "lixões". Neste caso a referência é feita aos lixões.
} 
aumentando os gastos públicos. Para este modelo foi considerada uma ocupação de um aterro com capacidade máxima de 800 mil toneladas, tamanho de um aterro de médio porte.

Acontece que nem tudo é coletado e destinado corretamente. Uma parte do RCD gerado é descartada ilegalmente na malha urbana das cidades. Além de retrabalhos operacionais das empresas de coleta para recolher esses resíduos depois, com maiores custos logísticos, há impactos tanto sociais como ambientais proporcionados pela poluição visual, agressão ao meio ambiente e possibilidade de ocorrência de focos de vetores de doenças como a dengue.

Por isso, o descarte ilegal é bastante custoso. Este é o custo da ilegalidade ou do recolhimento do RCD depositado na malha urbana, que, segundo a Companhia de Limpeza Urbana do Rio de Janeiro (Comlurb), pode ser estimado hoje em 70,00 R $\$ / t$ no município do Rio.

Apesar de no Brasil essa ilegalidade ser "tolerada", em países europeus, por exemplo, são cobradas multas às empresas que forem flagradas descartando em locais não autorizados. Isso mostra a diferença no nível de sustentabilidade promovido entre os países.

Também segundo a Comlurb, o motivo da ilegalidade é o elevado custo do descarte legal dos resíduos. No Brasil esse descarte é feito nos aterros públicos, onde a taxa de entrada cobrada pode chegar a até $20,00 R \$ / t$. Ou seja, essa taxa é considerada a principal influência na proporção que será descartada ilegalmente, ou, quanto menor o preço, tanto no aterro como nas recicladoras, mais aptos a descartar de maneira legal estarão os geradores, sendo menor a proporção descartada ilegalmente, seguindo uma relação de acordo com a Figura 5.6.

Tanto o percentual de descarte ilegal quanto os percentuais que serão levados aos três destinos são influenciados pelos valores da taxa de entrada na planta de reciclagem e pelo volume de $\mathrm{RCD}$ sendo reciclado, de maneira que quanto mais é reciclado na cidade e/ou menor o valor da taxa de entrada cobrada, mais estímulo outros geradores terão para reciclar seus resíduos e coletá-los corretamente. Essa relação de causa efeito é representada conforme demonstrado na Figura 5.6. 


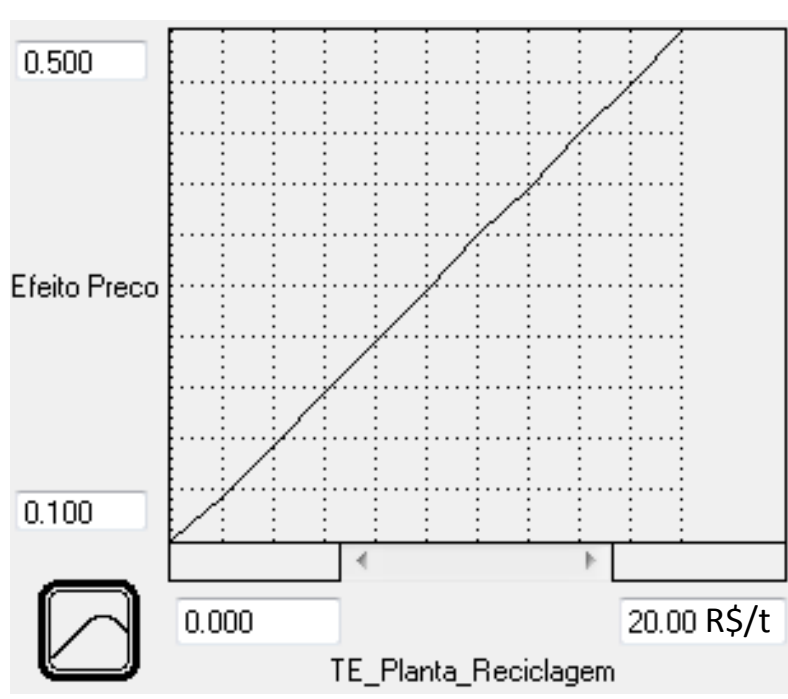

(a)

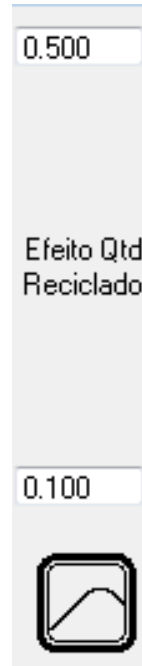

Eleito Qtd

0.000 RCD_reciclado

(b)

Figura 5.6 - Efeito do preço cobrado na entrada (a) e da quantidade que é reciclada (b) sobre os percentuais.

Para cada valor da taxa de entrada na planta ou no volume de RCD reciclado haverá um valor do efeito do preço e da quantidade sendo reciclada. A combinação dos dois valores dos efeitos causa o impacto geral nos percentuais, equacionados a partir das estimativas das relações de causa efeitos após coleta dos dados de entrevistas e visitas a plantas no Brasil, apontados nas equações a seguir:

Perc Reciclavel $=0.7^{*}\left(1-\left(E X P\left((-20 / \text { Efeito_Preco })^{*}(\text { Efeito_Qtd_Reciclado-0.1 })^{*} 0.13\right) /\left(1.7^{*}(1-\right.\right.\right.$

Efeito_Preco/2))))

O percentual de reuso é considerado também proporcional ao preço cobrado na entrada de RCD da planta e o volume de RCD reciclado. Quanto maior o preço, menos estímulos haverá para reciclar, sendo mais barato reutilizar o RCD gerado. Isso é mostrado na equação a seguir, que também combina os dois efeitos:

$$
\text { Perc Reuso }=\text { Efeito_Preco/3+0.01/Efeito_Qtd__Reciclado }
$$

O destino do restante será o aterro sanitário cuja equação é, portanto:

$$
\text { Perc Aterro = 1-(Perc Reuso }+ \text { Perc Reciclavel })
$$

As receitas geradas na planta de reciclagem são provenientes de duas fontes: a taxa de entrada cobrada na chegada da caçamba e a venda dos materiais reciclados. Dependendo do cenário das condições de cada cidade, a receita total não será 
suficiente para cobrir os custos operacionais e de capital, sendo necessário um subsídio para zerar o balanço. Como as plantas para este modelo foram projetadas sem fins lucrativos, o subsídio será a diferença entre o custo e a receita e será financiado pelo governo.

Portanto, o custo total de gerenciamento do RCD pode ser representado como a soma dos custos totais de coleta, classificação e separação de aterro, de reciclagem, de ilegalidade e do subsídio à reciclagem. Sua equação é representada a seguir:

\section{CT Gerenciamento RCD =}

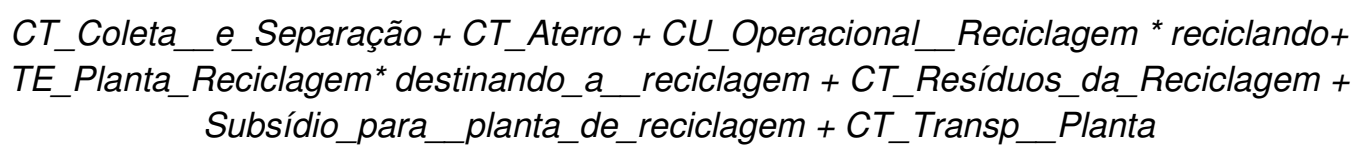

\subsubsection{Os benefícios da reciclagem do RCD}

Já os benefícios são representados como a soma das economias proporcionadas pelo descarte nas plantas de reciclagem, com o que será deixado de comprar de agregado natural, bem como as receitas geradas com a reciclagem e reuso. É representada na fórmula:

\section{Benefícios da reciclagem $=$}

$[($ destinando a reciclagem + reutilizando $) *(T D$ Aterro - TE Planta Reciclagem $)+($ reciclando + reutilizando) * PU Agregados naturais + Receita com Reciclado + Receita com Reuso]

\subsubsection{Análise de custo-benefício}

É a diferença entre os benefícios e custos de se gerenciar e controlar o RCD gerado na cidade. É a variável do modelo que mostrará se é válido promover e incentivar a reciclagem na cidade ou não, tanto no ponto de vista do governo, que arca com os custos de infraestrutura dos aterros, suas operações e compra de agregados para novas construções, como dos geradores, que pagam pelo descarte do RCD e também pelos agregados. Ambos sairão ganhando quando maior for a relação custo-benefício. 
Tabela 5.1 - Resumo das premissas consideradas para o modelo 1.

\begin{tabular}{|c|c|c|c|c|}
\hline \multicolumn{2}{|l|}{ Dados de entrada } & Unidade & Valores & Obs \\
\hline Do sistema & Abreviatura & & & \\
\hline Taxa de geração de RCD & Geração de RCD & t/ano & função & inicial de $100 \mathrm{mil}$ \\
\hline Limite de espaço no aterro & Limite de espaço & $\mathrm{t}$ & 800000 & fixo nos 20 anos \\
\hline Taxa de crescimento & - & $\% / a n o$ & função & média de $3 \%$ \\
\hline Preço de revenda de reutilizados & PU revenda Reutilizados & $R \$ / t$ & $10->13$ & aumento nos 20 anos \\
\hline Preço dos agregados naturais & PU agregados naturais & $\mathrm{R} \$ / \mathrm{t}$ & $30->36$ & aumento nos 20 anos \\
\hline Preço de venda de reciclados & PU venda reciclados & $\mathrm{R} \$ / \mathrm{t}$ & função & $70 \%$ do valor dos naturais \\
\hline Taxa de descarte no aterro & TD Aterro & $\mathrm{R} \$ / \mathrm{t}$ & função & TD Plant Rec +1 \\
\hline Investimento Inicial & - & $\mathrm{R} \$$ & 5,2milhões & terreno+equip+construção \\
\hline Taxa de entrada na Planta de Recic. & TE Planta Reciclagem & $\mathrm{R} \$ / \mathrm{t}$ & variável & em análise \\
\hline Proporções & & & & \\
\hline de ilegalidade & Percilegal & $\%$ & função & combinação dos 2 efeitos \\
\hline destinado ao aterro & Perc aterro & $\%$ & função & 1-pec aterro-perc reciclavel \\
\hline reutilizado & perc reuso & $\%$ & função & combinação dos 2 efeitos \\
\hline reciclavel & perc reciclavel & $\%$ & funçao & combinação dos 2 efeitos \\
\hline reciclado & perc reciclado & $\%$ & $85->95$ & aumento nos 20 anos \\
\hline Custos Unitários & & & & \\
\hline Ilegalidade(Meio Ambiente) & CU llegalidade & $\mathrm{R} \$ / \mathrm{t}$ & $50->70$ & aumento nos 20 anos \\
\hline Coleta e Separação & CU Coleta e Separação & $\mathrm{R} \$ / \mathrm{t}$ & $7->9$ & aumento nos 20 anos \\
\hline Reciclagem(Operacional variavel) & CU Operacional Reciclagem & $\mathrm{R} \$ / \mathrm{t}$ & $9->11$ & aumento nos 20 anos \\
\hline Reciclagem(Operacional Fixo) & Custo Fixo & $\mathrm{R} \$ / \mathrm{t}$ & $500->550 \mathrm{mil}$ & aumento nos 20 anos \\
\hline Aterro & CU Operacional Aterro & $\mathrm{R} \$ / \mathrm{t}$ & $5->7$ & aumento nos 20 anos \\
\hline Reciclagem(Capital) & Custo de capital & $\mathrm{R} \$$ /ano & 453.360 & Pgto anual do Inv.Inic. a $6 \%$ aa \\
\hline
\end{tabular}

Fonte: entrevistas e visitas técnicas, compilada pelo autor.

Para garantir maior realidade e dinâmica ao sistema, foram considerados aumentos dos preços ao longo dos 20 anos, explicados pelo aumento da inflação, aumento salarial, que aumentam os custos operacionais. Esse aumento é representado na coluna Valores através da seta de transição entre os valores. Por exemplo, para o custo unitário de ilegalidade (CU llegalidade) foi estimado um aumento de $2 \%$ ao ano, passando de $\mathrm{R} \$ 50,00 / \mathrm{t}$ no ano de 2012 para $\mathrm{R} \$ 70,00 / \mathrm{t}$ em 2032.

\subsubsection{Cenários considerados}

Os cenários propostos a seguir são baseados no motivo considerado principal para a falta de estímulo ao descarte de RCD em áreas de reciclagem, que é justamente o custo que o descarte representa aos geradores através das taxas de entrada cobrada nos aterros. Portanto, os seguintes cenários foram considerados com a inserção da planta de reciclagem como outra possibilidade de destino do RCD:

Cenário 1: Não é cobrada taxa de entrada na planta de reciclagem.

Cenário 2: Taxa de entrada na planta de reciclagem constante de 5,00 R\$/t. 
Cenário 3: Taxa de entrada na planta de reciclagem constante de 10,00 R $\$ / \mathrm{t}$.

Cenário 4: Taxa de entrada na planta de reciclagem constante de 15,00 R\$/t.

Cenário 5: Taxa de entrada na planta de reciclagem constante de 20,00 R\$/t.

\subsubsection{Resultados}

Depois de simulados os cenários, foram gerados quatro gráficos que evidenciam suas diferenças e os resultados entre o espaço disponível para descarte, custo total ao meio ambiente, a quantidade acumulada de subsídio ao longo dos 20 anos e a relação custo-benefício.

A Figura 5.7 ilustra o impacto da variação de preços de entrada na planta sobre a ocupação dos aterros. Percebe-se que quanto menor o preço cobrado na taxa de entrada dos resíduos na planta de reciclagem, mais tempo será necessário para que o aterro atinja sua lotação. Isso pode ser explicado pelo estímulo máximo aos geradores em reciclarem seus resíduos. Além de não se pagar nada pelo descarte na usina de reciclagem, maior será a quantidade sendo coletada corretamente e reciclada no município, o que incentiva ainda mais outros geradores a fazerem o mesmo. Neste caso de Macaé o espaço considerado não seria suficiente para os 20 anos, o que aumentaria os custos do governo para aquisição de novos terrenos.

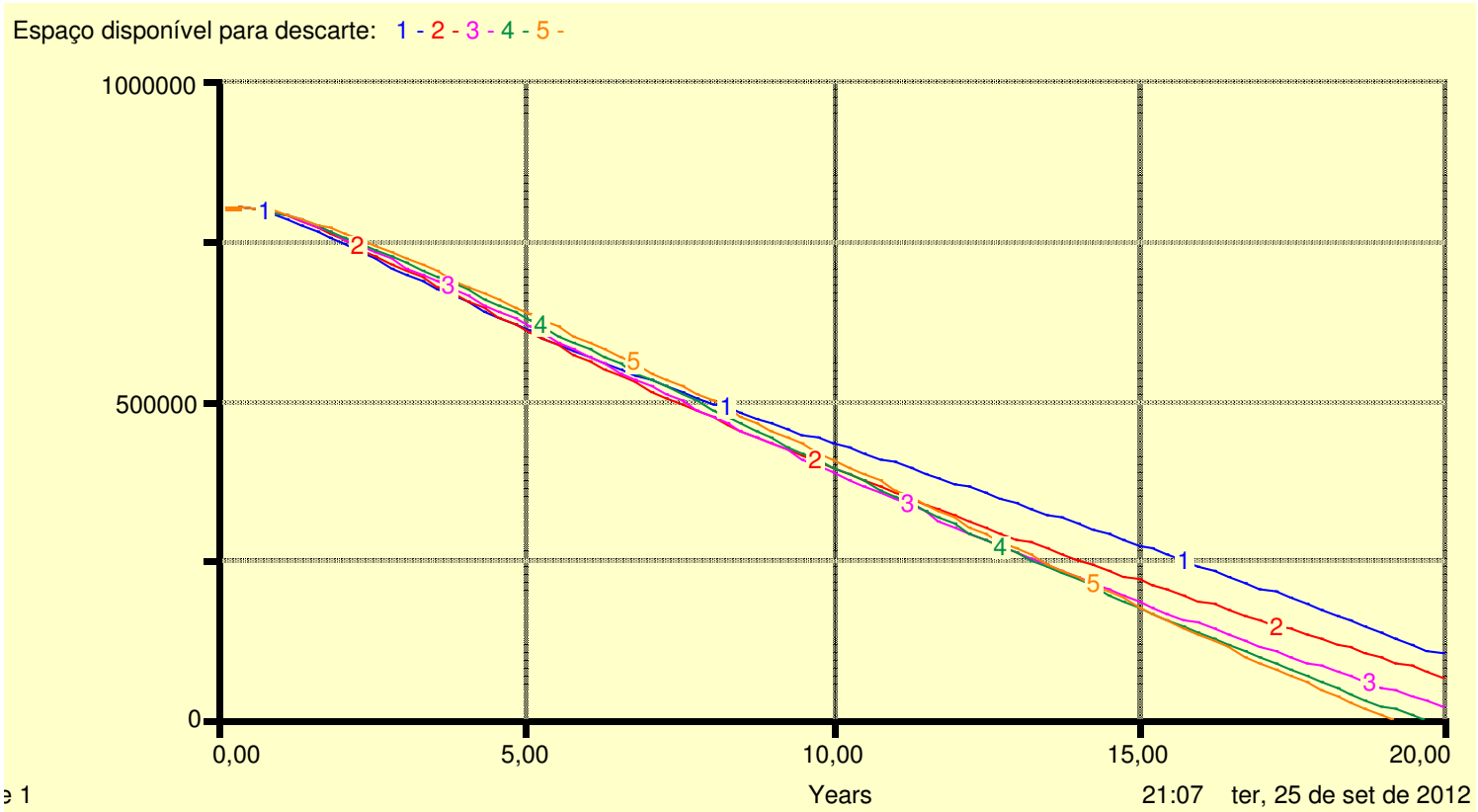

Figura 5.7 - Resultado simulado do espaço disponível para descarte para cada cenário na cidade de Macaé (vida útil do aterro). 
Na Figura 5.8 percebe-se que o custo ao meio ambiente, proporcional ao nível de irregularidade de cada ano devido a disposição irregular, será maior quanto maior o preço, como já era de se esperar. Isso pode ser explicado pelos efeitos dos preços e da quantidade reciclada. Além disso, fica claro que não basta apenas o estímulo do preço e da quantidade sendo reciclada. Por mais que o percentual de irregularidade diminua ao longo do tempo, essa redução será sobre um volume de RCD gerado, que é cada vez maior, elevando o custo total a cada ano. Somente quando a taxa de entrada na planta de reciclagem é muito baixa, o custo da irregularidade será menor do que hoje em dia. Ou seja, outros incentivos serão necessários para continuar reduzindo os custos com o recolhimento da irregularidade.

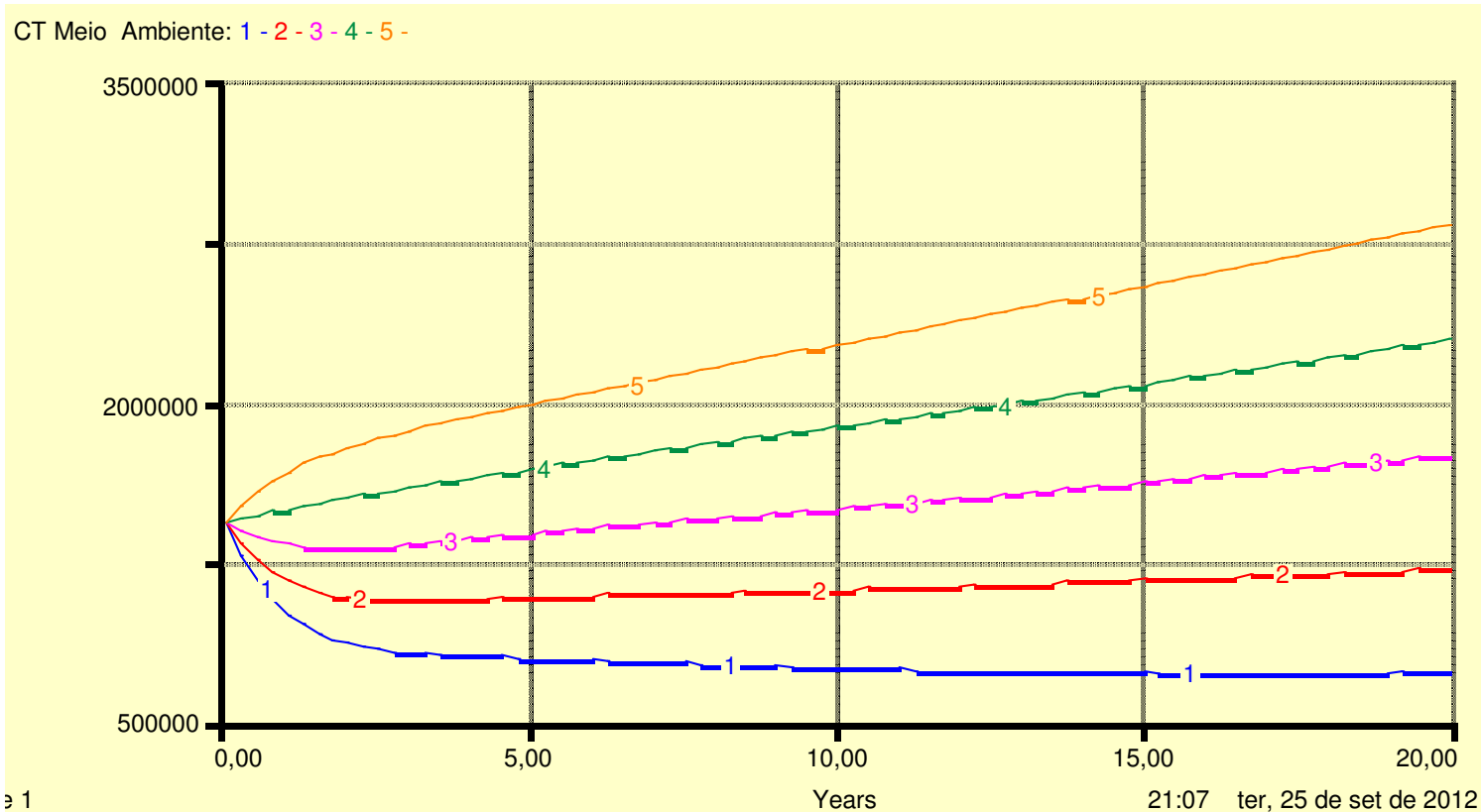

Figura 5.8 - Resultado simulado do custo total ao meio ambiente com a ilegalidade para cada cenário considerado na cidade de Macaé.

Outra conclusão foi relativa à quantidade total de subsídio que a planta recicladora precisará para cobrir seus custos, visto na Figura 5.9, que ilustra a quantidade de subsídio recebida desde o ano zero. O menos custoso para o serviço público de limpeza, portanto, é o cenário 4 , com a taxa de $R \$ 15,00 /$ t. 
Subsidio acumulado: 1 - 2 - 3 - 4 - 5 -

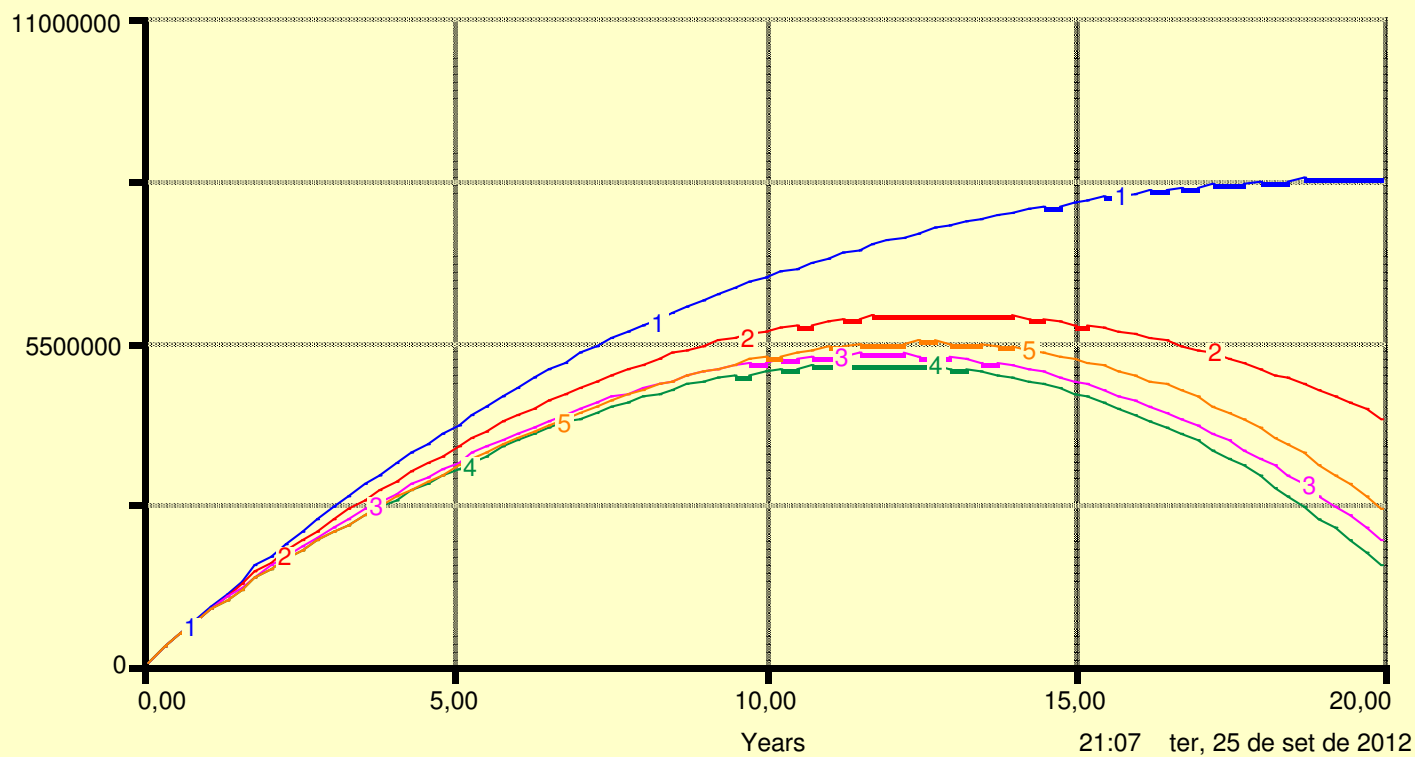

Figura 5.9 - Resultado simulado do valor acumulado de subsídio nos três cenários considerados para Macaé.

Percebe-se que, a partir do décimo segundo ano, haverá declínio nas curvas de subsídios. Isso acontece devido ao estímulo cada vez maior à reciclagem com o aumento da quantidade sendo reciclada na cidade. Nesta fase, a planta atinge o máximo de subsídio recebido e começará a gerar mais receita do que custos, devendo, na prática, retornar a diferença ao governo. Cada cenário acumulará os subsídios recebidos ao longo dos 20 anos, conforme a Tabela 5.2.

Tabela 5.2 - Valores aproximados dos subsídios para cada cenário

\begin{tabular}{cccc}
\hline Taxa de Entrada & Cenário & Máximo de Subsídio Atingido & Subsídio acumulado final \\
\hline $\mathrm{R} \$ 0,00 / \mathrm{t}$ & 1 & $\mathrm{R} \$ 10100000,00$ & $\mathrm{R} \$ 8200000,00$ \\
\hline $\mathrm{R} \$ 5,00 / \mathrm{t}$ & 2 & $\mathrm{R} \$ 7100000,00$ & $\mathrm{R} \$ 4200000,00$ \\
\hline $\mathrm{R} \$ 10,00 / \mathrm{t}$ & 3 & $\mathrm{R} \$ 6300000,00$ & $\mathrm{R} \$ 2100000,00$ \\
\hline $\mathrm{R} \$ 15,00 / \mathrm{t}$ & 4 & $\mathrm{R} \$ 6130000,00$ & $\mathrm{R} \$ 1600000,00$ \\
\hline $\mathrm{R} \$ 20,00 / \mathrm{t}$ & 5 & $\mathrm{R} \$ 6510000,00$ & $\mathrm{R} \$ 2600000,00$ \\
\hline
\end{tabular}

Conclui-se pela Figura 5.10 que, independentemente do preço cobrado, haverá uma relação custo benefício positiva e crescente. Ou seja, os benefícios gerados são mais quantitativos do que os custos gerados com a reciclagem. Este é um indicador de que a reciclagem deve ser estimulada.

Percebe-se que, inicialmente, quanto mais barato for para descartar os resíduos nas plantas de reciclagem, melhores são os benefícios. Só que, a longo prazo, as 
receitas geradas são mais significativas, bem como o nível de irregularidade proporcional ao preço cobrado. Levando isso tudo em consideração, o cenário 3 é o que proporciona maiores benefícios por conta principalmente da maior receita gerada com o percentual que é destinado corretamente e que é reciclado.

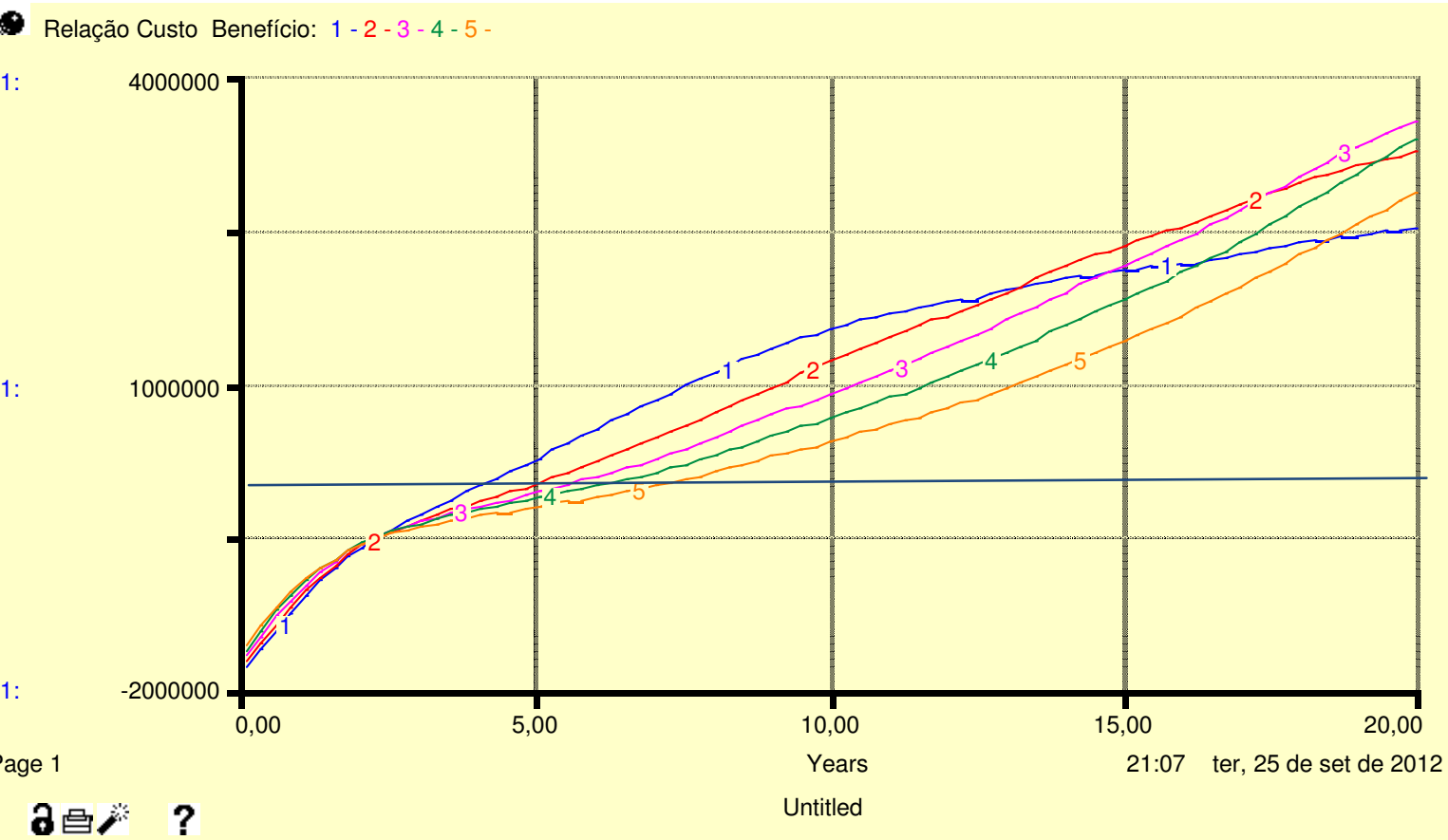

Figura 5.10 - Resultado simulado da relação custo benefício para cada cenário da taxa de entrada na planta de reciclagem em Macaé.(1-5,00R $\$ / t ; 2-10,00 R \$ / t, 3-5,00 R \$ / t)$.

Como pôde ser visto, 20 anos consistem em um longo período de tempo para se pagar o investimento. Uma elevada quantia deverá ser desembolsada em subsídios se comparada ao investimento inicial de 5 milhões de reais. A diferença nas curvas de subsídios pode ser explicada pelo maior percentual reciclado e menor ilegalidade conforme a taxa de entrada cobrada ser mais baixa, mas em contrapartida é gerada uma menor receita para a planta. Portanto, o cenário 3 apresenta melhor custobenefício do que o cenário 4 mas é o que necessita de mais subsídios do Serviço Público. Já a uma taxa de 10,00 R\$/t haverá maior quantidade de subsídio, mas em contrapartida haverá menor custo ao meio ambiente diante da menor quantidade que será descartada ilegalmente se comparada com o cenário 4 de 15,00R $\$$ t. Por isso, o cenário onde a taxa de entrada na planta de reciclagem seja de 10,00 R $\$ / t$ é o mais recomendado para a cidade de Macaé. E diante da nova política de resíduos sólidos (Lei 12.305 de 2010), será ainda necessário equacionar a maneira como a 
indústria da construção civil arcará com esses subsídios, visto que a política do poluidor-pagador é um princípio desta lei.

\subsubsection{Comparativo entre as cidades analisadas}

Depois de aplicar o modelo 1 na cidade de Macaé, o mesmo modelo foi levemente adaptado para que fosse possível estudar os comportamentos nas outras duas cidades analisadas neste trabalho (São Paulo e Maceió) e comparar os efeitos e resultados. Dessa maneira, será possível verificar a melhor relação de custo benefício, o volume de subsídio, bem como os impactos nos aterros e ao meio ambiente em cada cidade.

Para isso, foram necessárias modificações nos dados de entrada do modelo, visto que são três realidades bem diferentes, tanto do ponto de vista econômico, cultural como também político. Ou seja, não só os custos envolvidos nos processos, mas também os incentivos históricos para a reciclagem em cada cidade são diferentes.

Assim como em Macaé, foram pesquisados dados operacionais como custos de equipamentos, de terreno, dados das populações, expectativa de crescimento, preços dos agregados naturais, dos reutilizados e seus percentuais em cada cidade. Foi possível observar, como já era de se esperar, que São Paulo, por ser a maior cidade, é também a que possui custos mais elevados, pagando-se mais pela mão de obra, pelos bens de produção, tornando os processos mais caros.

Outro ponto a destacar é a quantidade de RCD gerada em cada cidade e o quanto efetivamente será reciclado deste total ao longo dos vinte anos. Com relação ao tamanho da região de São Paulo analisada, foi considerado apenas o raio onde a população tinha alguma relação com o RCD amostrado, sendo estimados em 600 mil habitantes, o que equivaleria a 300 mil toneladas de RCD gerada ao ano. Pelos dados históricos fornecidos pelo IBGE, percebeu-se que o tamanho da população tanto de Maceió como em São Paulo encontra-se em fase já de desaceleração de crescimento. Por isso, foi estimado um crescimento anual de apenas $1 \%$, diferente dos 3\% ao ano considerado em Macaé. 
Tabela 5.3 - Dados de entrada pesquisados para as três cidades para a aplicação do modelo 1.

\begin{tabular}{|c|c|c|c|c|}
\hline Dados de entrada & Unidade & Macaé & São Paulo & Maceió \\
\hline \multicolumn{5}{|l|}{ Do sistema } \\
\hline Taxa de geração de RCD & t/ano & 100000 & 300000 & 200000 \\
\hline Limite de espaço no aterro & $t$ & 800000 & 800000 & 800000 \\
\hline Taxa de crescimento & $\% / a n o$ & $3 \%$ & $1 \%$ & $1 \%$ \\
\hline Preço fração mineral reutilizada & $\mathrm{R} \$ / \mathrm{t}$ & $10->13$ & $20->30$ & $8->11$ \\
\hline Preço dos agregados naturais & $\mathrm{R} \$ / \mathrm{t}$ & $35->41$ & $50->65$ & $25->35$ \\
\hline Preço de venda de agregados reciclados & $\mathrm{R} \$ / \mathrm{t}$ & $70 \%$ & $70 \%$ & $70 \%$ \\
\hline Taxa de descarte no aterro & $\mathrm{R} \$ / \mathrm{t}$ & $f$ & $f$ & $f$ \\
\hline Investimento Inicial & $\mathrm{R} \$$ & 5,2milhões & 16milhões & 4milhões \\
\hline Quantidade referência reciclada & & 1500000 & 2000000 & 1800000 \\
\hline \multicolumn{5}{|l|}{ Custos Unitários } \\
\hline \multicolumn{5}{|l|}{ Operações } \\
\hline Ilegalidade (Meio Ambiente) & $\mathrm{R} \$ / \mathrm{t}$ & $50->70$ & $70->90$ & $40->60$ \\
\hline Coleta e Separação & $\mathrm{R} \$ / \mathrm{t}$ & $7->9$ & $9->11$ & $4->6$ \\
\hline Reciclagem (Operacional variável) & $\mathrm{R} \$ / \mathrm{t}$ & $8->10$ & $11->13$ & $7->9$ \\
\hline Reciclagem (Operacional Fixo) & $\mathrm{R} \$ /$ ano & $500->550 \mathrm{mil}$ & $\begin{array}{l}1000- \\
>1100\end{array}$ & $\begin{array}{c}400- \\
>450 \mathrm{mil}\end{array}$ \\
\hline Aterro & $\mathrm{R} \$ / \mathrm{t}$ & $5->7$ & $6->8$ & $4->5$ \\
\hline Reciclagem (Capital) & $\mathrm{R} \$$ /ano & 453360 & 2092243 & 435923 \\
\hline
\end{tabular}

Já por ser cidade grande e ao mesmo tempo mais desenvolvida, estimou-se também que a reciclagem em São Paulo seria bem aceita e mais incentivada. Essas estimativas são importantes para a formulação das hipóteses de causa-efeito, por exemplo, no percentual que será reciclado e reutilizado de acordo com os preços e quantidades sendo recicladas (efeito preço e efeito quantidade), sendo necessário modificar os parâmetros das equações sugeridas no caso de Macaé. E esses parâmetros foram escolhidos na tentativa e erro através das simulações até que se chegasse ao comportamento esperado dos percentuais de ilegalidade, de reuso e de reciclagem em função do tempo, sem a preocupação com os resultados finais (volume de subsídio, custo-benefício e os outros). Ou seja, determinada a hipótese de comportamento diante de cada realidade, a cada simulação foram feitas correções nos parâmetros até que se chegou ao desejado fisicamente, e não financeiramente.

As equações das proporções de RCD que serão descartadas ilegalmente nos aterros, nas plantas de reciclagem ou mesmo reutilizada são determinadas em função dos valores iniciais pesquisados com as prefeituras e construtoras das 
cidades bem como as perspectivas de evolução desses percentuais nos 20 anos, considerando a existência das plantas de reciclagem e do quanto é cobrado por tonelada para nela depositarem o RCD.

Nesse sentido, as equações mencionadas para cada cidade são mostradas na Tabela 5.4 .

Tabela 5.4 - Equações dos percentuais determinadas a partir dos valores iniciais pesquisados e espectativas de comportamento nos 20 anos.

\begin{tabular}{|c|c|c|}
\hline Percentuais envolvidos & em $t=0$ & Equação para $0<\mathrm{t}<20$ anos \\
\hline \multicolumn{3}{|l|}{ de ilegalidade } \\
\hline Macaé & $25 \%$ & Efeito_Preco/2+0.01/Efeito_Qtd_Reciclado \\
\hline São Paulo & $15 \%$ & Efeito_Preco/6+0.01/Efeito_Qtd_Reciclado \\
\hline Maceió & $50 \%$ & Efeito_Preco/1+0.02/Efeito_Qtd_Reciclado \\
\hline \multicolumn{3}{|l|}{ de reuso } \\
\hline Macaé & $35 \%$ & Efeito_Preco/2+0.02/Efeito_Qtd_Reciclado \\
\hline São Paulo & $15 \%$ & Efeito_Preco/3+0.01/Efeito_Qtd_Reciclado \\
\hline Maceió & $15 \%$ & Efeito_Preco/3+0.01/Efeito_Qtd_Reciclado \\
\hline \multicolumn{3}{|l|}{ de reciclagem } \\
\hline Macaé & $25 \%$ & $0.7^{*}\left(1-\left(\operatorname{EXP}\left((-20 /(\right.\right.\right.$ Efeito_Preco $)) *(($ Efeito_Qtd_Reciclado-0.1) $) * 0.13) /\left(1.7^{*}(1\right.$-Efeito_Preco/2) $\left.\left.)\right)\right)$ \\
\hline São Paulo & $25 \%$ & $0.7 *\left(1-\left(\operatorname{EXP}\left((-20 /(\right.\right.\right.$ Efeito_Preco $)) *(($ Efeito_Qtd_Reciclado-0.1) $) * 0.13) /\left(1.7^{*}(1\right.$-Efeito_Preco/2) $\left.\left.)\right)\right)$ \\
\hline Maceió & $15 \%$ & $0.6 *(1-(\operatorname{EXP}((-20 /($ Efeito_Preco $)) *(($ Efeito_Qtd_Reciclado-0.1) $) * 0.13) /(1.6 *(1-$ Efeito_Preco/2) $)))$ \\
\hline
\end{tabular}

Com essas equações formuladas foi possível simular os três cenários em que a taxa de entrada na planta de reciclagem é fixa em 10,00 $R \$ / t$. Os resultados são representados nas figuras a seguir.

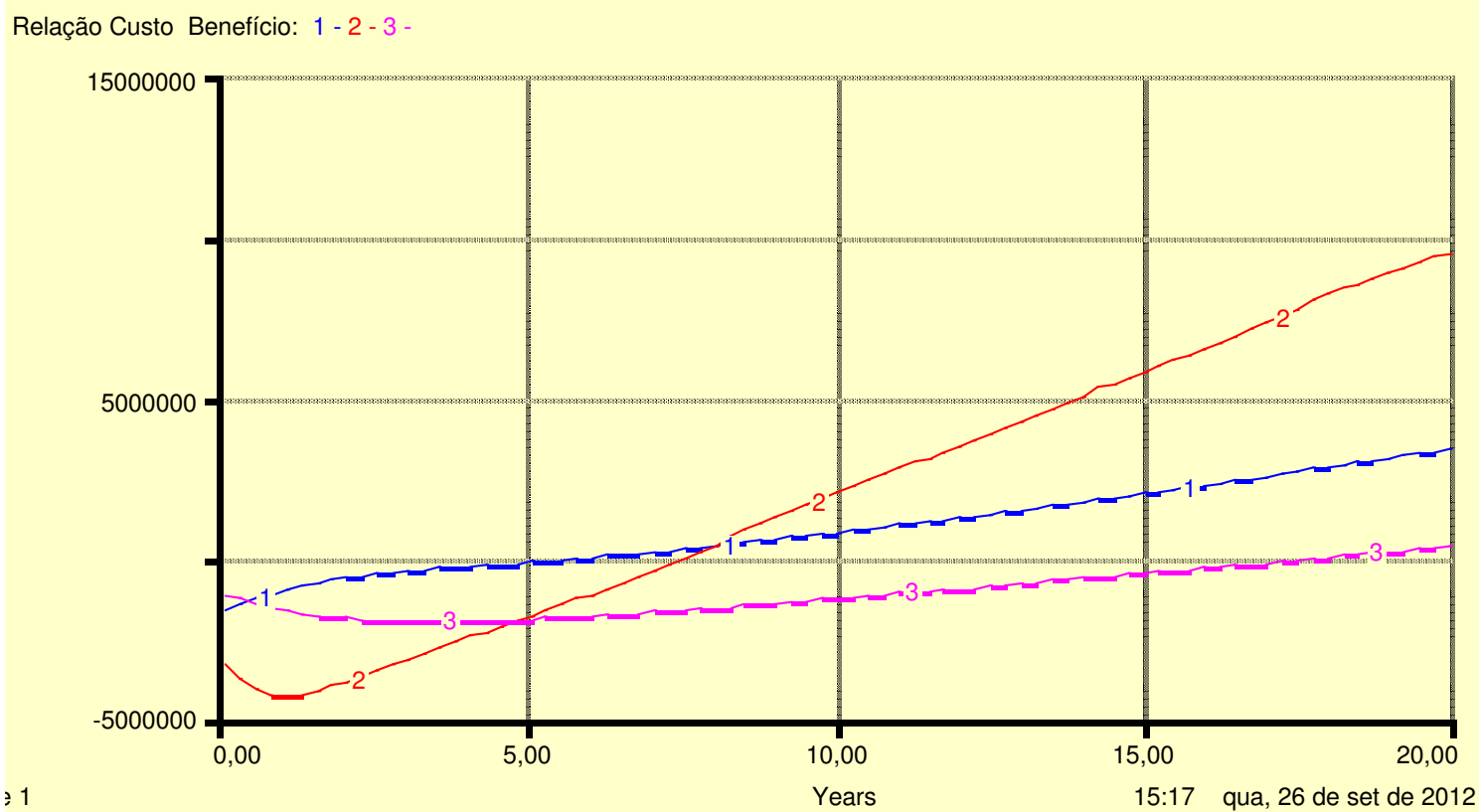

Figura 5.11 - Relação custo-benefício do gerenciamento do RCD para as três cidades. 1-Macaé, 2São Paulo, 3-Maceió 
Pela Figura 5.11 percebe-se que a cidade de Macaé é a primeira a apresentar uma relação custo benefício positiva, após cinco anos. São Paulo, apesar de só apresentar uma relação positiva após o sétimo ano, é a que trará maior valor no longo prazo. Nas três cidades estudadas, a existência de plantas de reciclagem e esforços para estabelecer uma política de gerenciamento do RCD traz mais benefícios do que custos no longo prazo. No curto prazo os investimentos são elevados, pesando para uma relação negativa, principalmente para a cidade de Maceió, que só terá uma relação positiva após 17 anos de funcionamento da planta e São Paulo, que diante do elevado investimento inicial de 16 milhões (8milhões de reais cada planta com capacidade $50 t / h$ ), mostra retorno já nos oito anos iniciais.

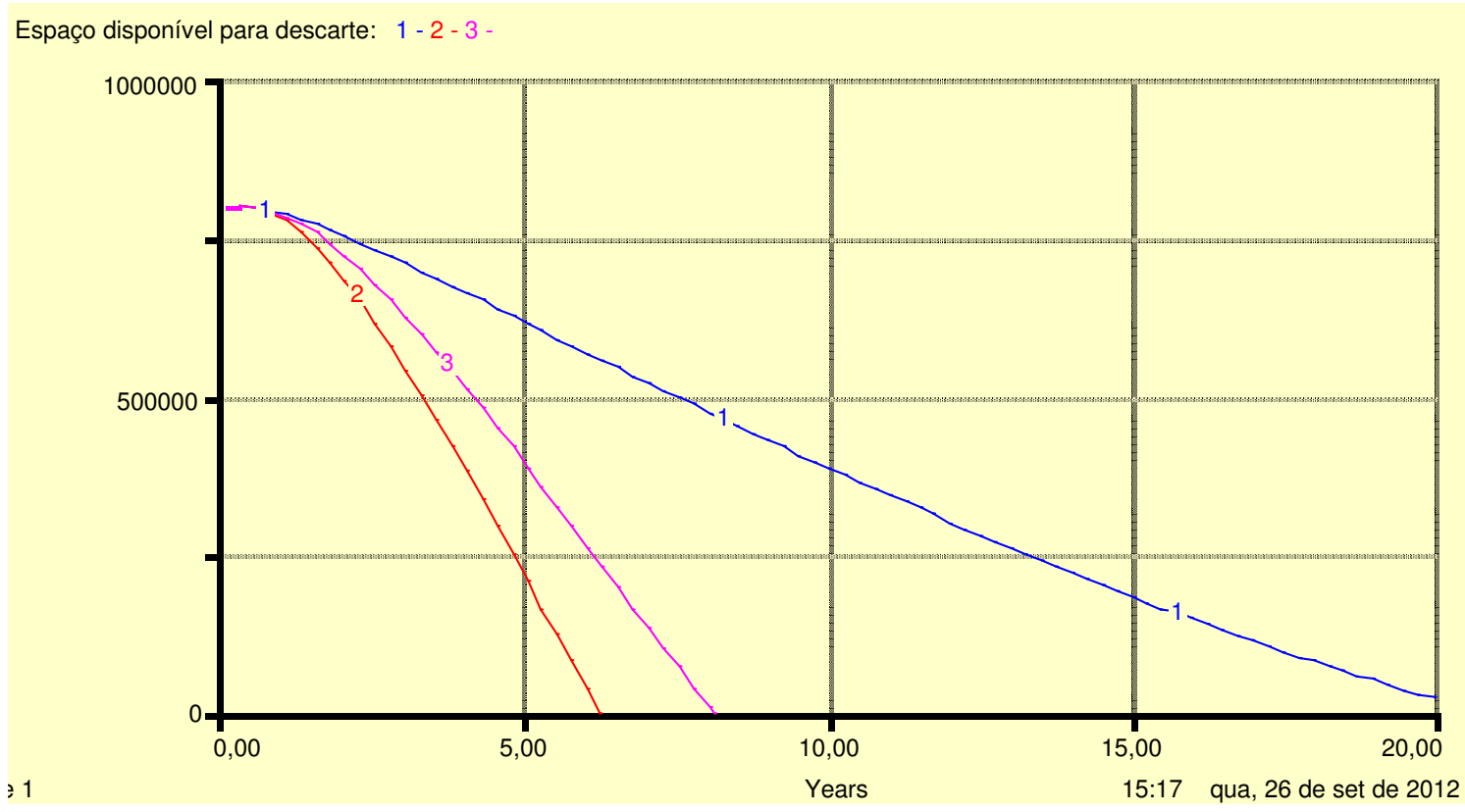

Figura 5.12 - Ocupação de um aterro virtual com a mesma área para as três cidades.

Na Figura 5.12 é refletida a necessidade de investigar novas maneiras de desestimular o descarte do RCD nos aterros. Apesar de o preço de entrada nas plantas de reciclagem ser ótimo, é preciso também criar incentivos para que geradores de RCD destinem cada vez mais seus resíduos para as plantas recicladoras ao invés dos aterros. Caso contrário, na região de São Paulo, por exemplo, seria preciso investir a cada 6 anos na aquisição de novas áreas de aterro em regiões cada vez mais urbanizadas, o que onera ainda mais os gastos públicos. 
CT Meio Ambiente: 1 - 2 - 3 -

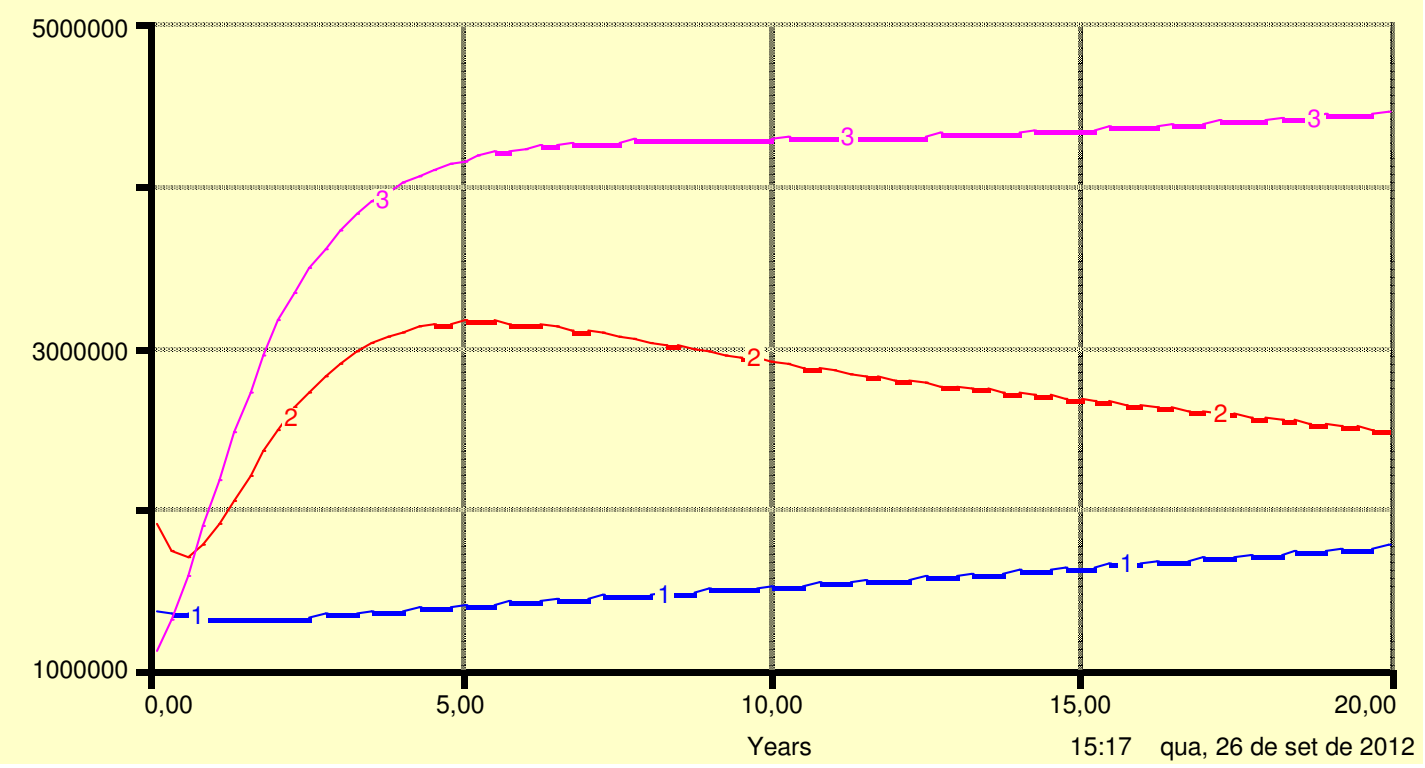

Figura 5.13 - Custo total proveniente do descarte ilegal nas malhas urbanas nas três cidades.

Pela Figura 5.13 percebe-se que a inserção das plantas de reciclagem reduz o ritmo atual de crescimento da irregularidade, uma vez que menos resíduos serão descartados na malha urbana. Em Macaé essa redução não é suficiente para compensar o aumento do volume de RCD gerado com o crescimento mais acelerado da população e do custo unitário da ilegalidade. Isso pode fazer com que Macaé atinja um custo de recolhimento em 20 anos quase equivalente a uma região em São Paulo, que possui um custo unitário maior e em maior volume.

Subsidio acumulado: $1-2-3-$

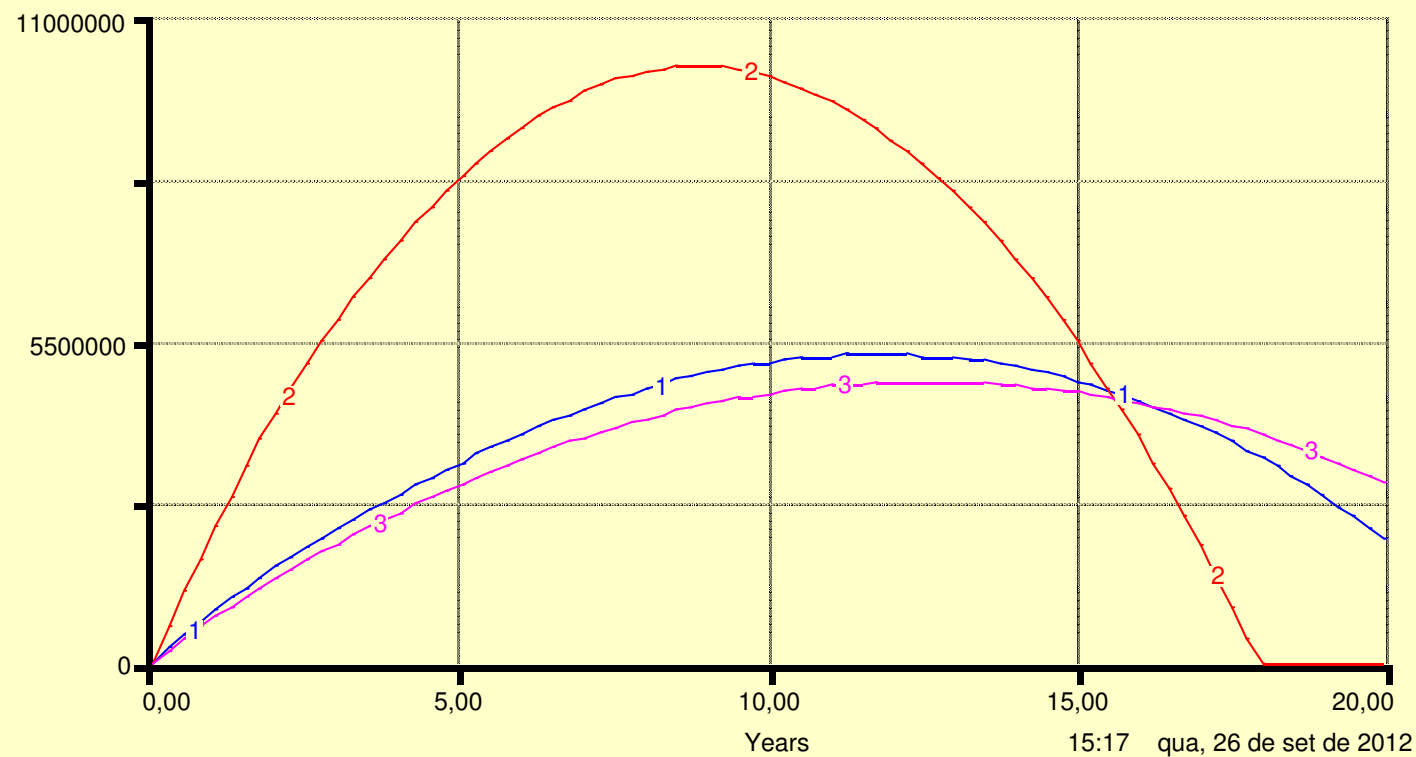

Figura 5.14 - Subsídio acumulado nas três cidades ao longo dos 20 anos com suas plantas de reciclagem. 
A Figura 5.14 mostra a quantidade de subsídio acumulada desde o início do projeto até $\mathrm{o}$ ano em questão. Percebe-se que as três cidades necessitam de subsídios inicialmente para poderem operar com custos superiores às receitas. Essas condições permanecem até certo ano quando a planta da região consegue gerar mais receitas do que custos, passando a retornar os subsídios aos municípios.

Tabela 5.5 - Subsídios acumulados em cada cidade ao longo dos 20 anos.

\begin{tabular}{cccc}
\hline Cidade & Cenário & Máximo de Subsídio Atingido & Subsídio acumulado final \\
\hline Macaé & 1 & $\mathrm{R} \$ 6300000,00$ & $\mathrm{R} \$ 2100000,00$ \\
\hline São Paulo & 2 & $\mathrm{R} \$ 7100000,00$ & $\mathrm{R} \$ 0,00$ \\
\hline Maceió & 3 & $\mathrm{R} \$ 4800000,00$ & $\mathrm{R} \$ 3100000,00$ \\
\hline
\end{tabular}

A única que conseguiria devolver todo o subsídio recebido seria a região de São Paulo. Isso acontece devido ao maior volume processado, que necessita de duas plantas de reciclagem, e aos maiores preços dos agregados reciclados. Maceió necessitaria de subsídios de cerca de 3 milhões de reais para viabilizar a reciclagem do RCD na cidade, mesmo após os 20 anos. Mesmo São Paulo só conseguiria pagar os subsídios recebidos a partir do décimo sétimo ano de investimento. Um risco que poucas empresas privadas estariam dispostas a enfrentar.

Por isso, no próximo modelo serão mais detalhadas as operações de reciclagem e será identificado como tornar esses empreendimentos mais rentáveis.

\subsection{MODELO 2: VIABILIDADE A PARTIR DA QUALIDADE}

segundo modelo proposto com aplicação de sistemas dinâmicos, diferentemente do primeiro, tem como objetivo avaliar a viabilidade econômica de uma usina de reciclagem em Macaé com diferentes cenários de acordo com o tipo de planta escolhido e da qualidade do RCD coletado na cidade.

Como visto nesta pesquisa, a composição do RCD gerado possui grande variabilidade entre as cidades. Esta interfere diretamente na qualidade do RCD que será processado para atingir maior valor agregado (com maiores resistências mecânicas para funções estruturais, por exemplo) e, consequentemente, na 
capacidade de geração de receita para a planta de reciclagem. Ou seja, em uma região na qual as usinas de reciclagem adotem uma política de aceitar apenas caçambas cuja composição do RCD possua maior percentual de material de boa qualidade (menos contaminantes, maior presença de concretos), haverá mais agregados reciclados de boa qualidade.

Dessa maneira, foram estudados dois modelos de plantas de reciclagem: uma planta fixa com circuito considerado como o de países emergentes com capacidade de $50 \mathrm{t} / \mathrm{h}$ e duas plantas móveis com capacidades de $25 \mathrm{t} / \mathrm{h}$ cada.

\subsubsection{Os circuitos em uma planta de reciclagem fixa}

Os resíduos de construção no Brasil, quando levados a centros de processamento da sua fração mineral, passam por diversas etapas:

1. Assim que chegam as caçambas com RCD na planta de reciclagem há uma inspeção visual, com 0 objetivo de rejeitar caçambas com muitos contaminantes ou materiais muito heterogêneos;

2. Sendo autorizada a entrada, esta caçamba é depositada em um estoque, onde será realizada uma catação manual, separando a fração não mineral como plástico, vidro, madeira, isopor, papel entre outros;

3. A fração mineral é levada por retro escavadeiras ao alimentador, a partir do qual será realizada a etapa de britagem, na qual haverá a redução do tamanho das partículas;

4. Logo depois há uma separacão magnética dos metais ferrosos seguidas da separacão granulométrica através das peneiras.

Esse é o circuito emergente, representado na Figura 5.15. 


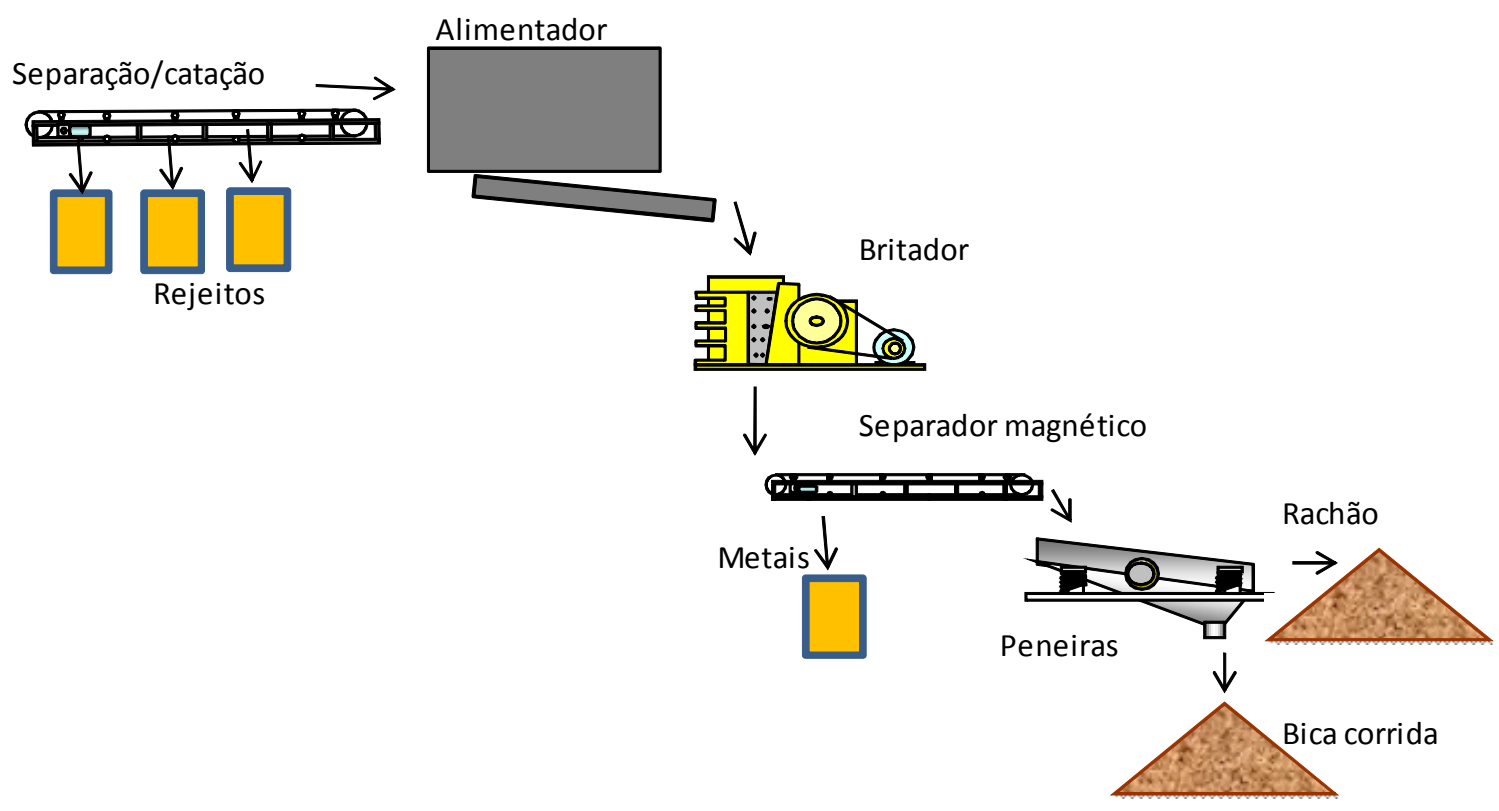

Figura 5.15 - "Circuitos emergentes" simplificado de beneficiamento nas plantas de reciclagem no Brasil.

\subsubsection{As plantas móveis de reciclagem}

As plantas móveis são também consideradas uma opção de investimento. Elas atuam pontualmente ou simultaneamente nas áreas onde haverá grande geração de resíduos, como grandes demolições ou construções. Apesar de ter que deslocar todo o maquinário pelas regiões da cidade, o custo de transporte somado para levar os resíduos até uma planta fixa é elevado, tornando a versão móvel passível de análise. Além disso, como a geração de resíduos é contínua ao longo do ano, não há necessidade de um terreno para alocar os equipamentos, sem custos, portanto, com aquisição de terreno nem com a construção de uma planta. 


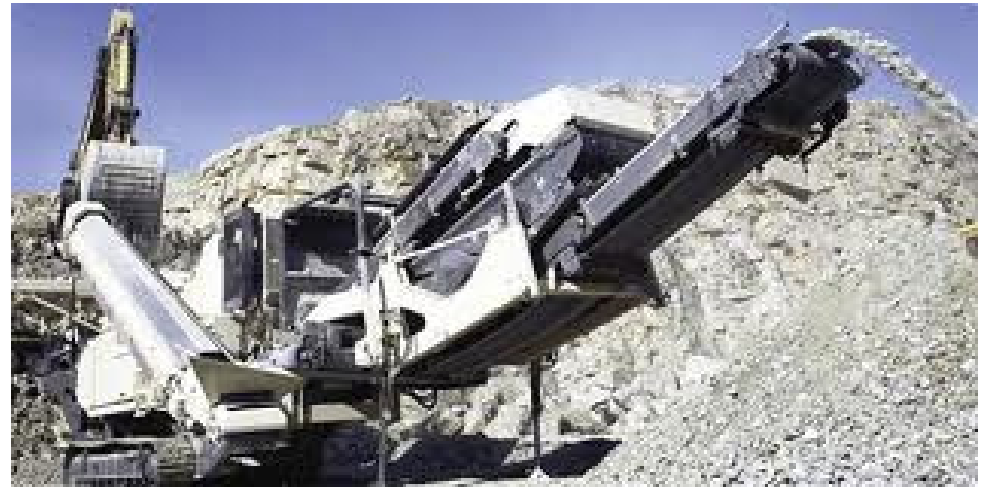

Figura 5.16 - Exemplo de planta móvel de reciclagem de RCD.

Fonte: Metso

A planta móvel realiza os mesmos processos encontrados em uma planta fixa de modo que o operador de escavadeira ou de pá-carregadeira consiga controlar toda a operação de britagem. Isso reduz não só os custos como também todo o sistema de carregamento. Assim, uma planta móvel possuirá um menor quadro de funcionários, bem como custos variáveis menores ao longo da operação, visto que os gastos com energia, água e rejeitos são proporcionais à quantidade de resíduo sendo processada na planta.

A partir de questionários, visitas a plantas de reciclagem e empresas de construção no Brasil foi montada a Tabela 5.6, a seguir, com as estimativas de custos operacionais e investimento inicial para cada tipo de planta. 
Tabela 5.6- Estimativa de custos para as versões de plantas de reciclagem estudadas.

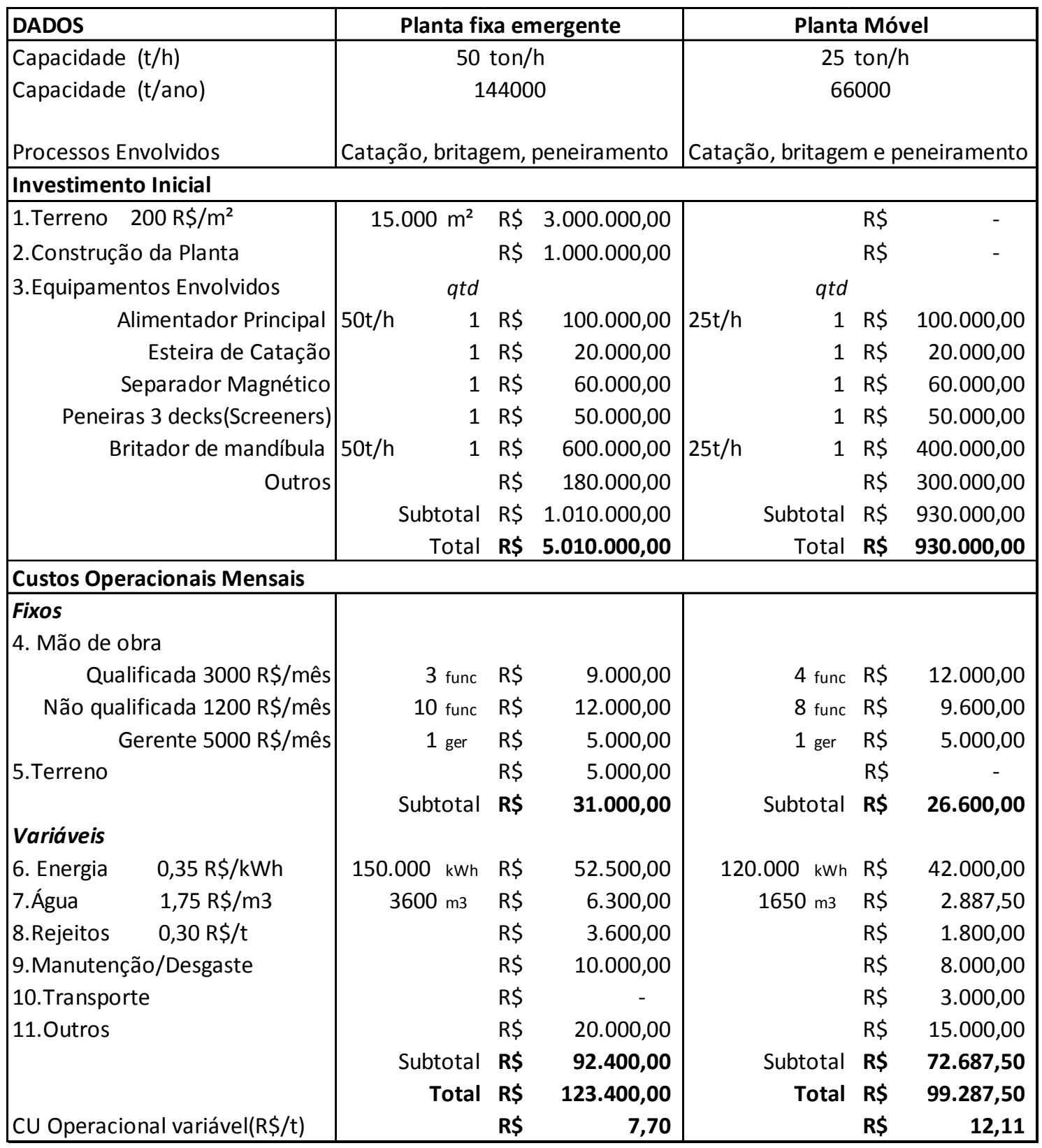

Segundo Zhao,W.;Leftink,R.B.;Rotter,V. (2009), a escolha do gerador de resíduo em descartar em uma planta fixa ou móvel dependerá da diferença nos custos entre elas, que deve ser comparada com a economia que seria realizada com a diferença de distâncias. Essa decisão é baseada na equação a seguir:

$$
|\mathrm{Rcf}-\mathrm{Rcm}|<\mathrm{Ut} \times \mathrm{La}
$$

Onde $\mathrm{Rcf}$ é o custo unitário de reciclagem em uma planta fixa e $\mathrm{Rcm}$, o custo unitário da reciclagem por uma planta móvel. Ut é o custo unitário do transporte e La representa a diferença de distância percorrida. 
Com os dados da tabela e sabendo que o custo unitário de transporte é de 0,80 $\mathrm{R} \$$ /t.km, uma planta móvel com custo unitário de $12,11 \mathrm{R} \$$ /t só seria escolhida ao invés de uma planta fixa com $7,70 \mathrm{R} \$ / \mathrm{t}$ caso a diferença de distância fosse de pelo menos $5,5 \mathrm{~km}$.

Como em muitas cidades grandes as plantas fixas podem ficar em regiões isoladas, ou centrais, o custo de transporte é debitado no usuário (construtor, demolidor). Portanto, a escolha entre que tipo de planta adotar dependerá de questões financeiras. Para isso foi realizado um modelo de viabilidade econômica com uso de sistemas dinâmicos. O modelo é representado na Figura 5.17. 


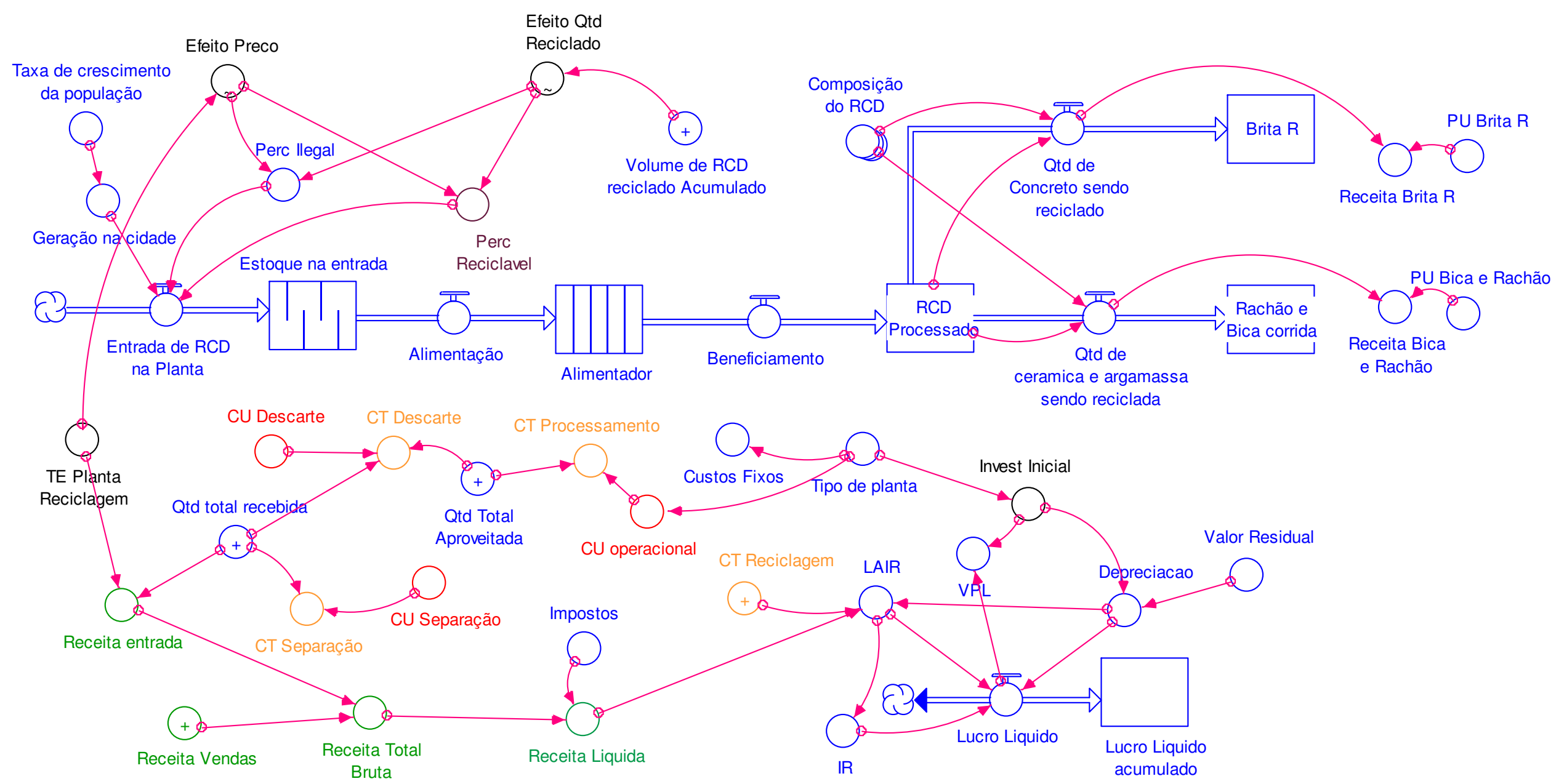

Figura 5.17 - Modelo dinâmico 2 proposto para análise de viabilidade econômica de usinas de reciclagem. 


\subsubsection{Variáveis analisadas}

Neste segundo modelo as variáveis estão divididas em dois grupos:

- Variáveis de entrada na planta;

- Variáveis operacionais e financeiras.

\subsubsection{Variáveis de entrada na planta:}

Composição do RCD

A composição do RCD que chega à planta é representada pelas proporções de cada material no RCD. Foram divididas em duas componentes (concreto; cerâmica + argamassa), que variam de acordo com cada cidade. Para esse estudo foi considerada as proporções das amostras levantadas e mostradas no capítulo 4 (Trabalho experimental), com o critério que a fase de alta qualidade, constituída praticamente por concreto, é aquela cuja densidade é maior do que $2,2 \mathrm{~g} / \mathrm{cm}^{3}(\mathrm{~d}>2,2$ $\left.\mathrm{g} / \mathrm{cm}^{3}\right)$. Já a fase de média e baixa qualidade, constituídas de argamassa + cerâmica, apresenta $d<2,2 \mathrm{~g} / \mathrm{cm}^{3}$. Essas proporções determinarão assim as quantidades de cada material no RCD que entra em cada planta de reciclagem. Sabe-se ainda que existem outras classificações que consideram solos, rochas, madeira, plásticos, papel, vidro, isopor e contaminantes (gesso e amianto), mas para efeito de simplificação na cidade de Macaé foram consideradas apenas as proporções de alta e média qualidade, diferenciadas por suas respectivas densidades.

Tabela 5.7 - Composição dos resíduos de alta e média qualidade na cidade analisada.

\begin{tabular}{ll}
\hline Composição & Macaé \\
\hline Concreto & $17 \%$ \\
\hline Cerâmica +Argamassa & $83 \%$ \\
\hline Total & $100 \%$ \\
\hline
\end{tabular}

\section{Capacidade de processamento}

As plantas de reciclagem atualmente no Brasil possuem capacidades de processamento variadas. Neste modelo a jornada de trabalho na planta fixa será de $10 \mathrm{~h} /$ dia, 24 dias no mês (somados dois sábados no mês) e capacidade de $50 \mathrm{t} / \mathrm{h}$, 
totalizando 144000 t/ano. Já uma planta móvel operaria também $10 \mathrm{~h} /$ dia, só que 22 dias $^{12}$ no mês e capacidade de $25 \mathrm{t} / \mathrm{h}$, totalizando $66000 \mathrm{t} / \mathrm{ano}$. Por isso, a fim de igualar as capacidades de processamento e as condições de comparação, há a necessidade de considerar duas plantas móveis em uma cidade.

\section{Entrada de RCD na planta}

Como visto no modelo anterior, uma parte do resíduo, antes de chegar à planta de reciclagem, é coletada (outra parte é descartada ilegalmente), passa por uma etapa de triagem onde são separados os contaminantes e o que será reutilizado. Dessa maneira, das milhares de toneladas geradas na cidade em um ano, inicialmente apenas uma parte chega à planta de reciclagem. Mesmo assim, ao chegar, é feita uma nova separação. Esse percentual é influenciado tanto pela quantidade sendo reciclada como pelo preço, assim como no modelo anterior, mesmo gráfico. Quanto mais se recicla, maior o efeito, maior o percentual que será reciclado (Figura 5.6).

\section{Agregados reciclados gerados}

Como citado anteriormente, foram considerados dois tipos de plantas: a fixa e a móvel. Nos dois casos, os produtos formados serão os mesmo, proporcionais aos percentuais de concreto e cerâmica presentes na composição, mas com preços de venda diferenciados. Por exemplo, a quantidade de bica corrida e brita recicladas formadas são, como mostrado nas equações abaixo baseadas nas proporções mencionadas no Capítulo 4.

$$
\begin{gathered}
\text { Qtd Concreto sendo reciclada }=\text { Composição_do_RCD[Concreto }{ }^{*} R C D \_ \text {Processado } \\
\text { Qtd de cerâmica e argamassa sendo reciclada }=\text { Composição_do_RCD[Ceramica }]^{*} \\
R C D \_ \text {Processado }
\end{gathered}
$$

\subsubsection{Variáveis Operacionais e Financeiras}

Estas variáveis resultarão nos custos e na geração de receitas da planta de reciclagem. As operações financeiras foram referenciadas pelo livro Análise de Investimentos de Caloba, G.M. et Motta, R.R., 2002.

\footnotetext{
${ }^{12}$ Os 22 dias foram considerados partindo do princípio que a planta móvel perde 2 dias para cada mudança de local de operação, que neste modelo será de 12 vezes por ano, ao custo de $\mathrm{R} \$ 3000,00$ por mudança.
} 


\section{$\underline{\text { Custos }}$}

Neste modelo, o custo total de reciclagem será a soma dos custos variáveis (representados pelos custos marginais) de processamento, classificação (considerado 2,00 R $\$ / t$ em todos os casos) e resíduos para descarte nos aterros, considerado em 11,00 R $\$$ /t (considerando a taxa de entrada no aterro). Os custos fixos variam em cada tipo de planta. É a soma dos gastos com funcionários e aluguel do terreno, considerados também na Tabela 5.6.

Portanto, a equação do Custo Total de reciclagem é representada da seguinte maneira:

$$
C T \_R e c i c l a g e m=C T \_D e s c a r t e+C T \_ \text {Processamento }+C T \_ \text {Separação }+ \text { Custos_Fixos }
$$

\section{$\underline{\text { Receita }}$}

Cada agregado possui seu valor médio de mercado, que, multiplicado pela quantidade respectiva reciclada, gerará a receita proveniente do material, como mostrado a seguir com o exemplo do concreto e da brita reciclada:

Receita Brita $R=Q t d \_d e \_C o n c r e t o \_s e n d o \_r e c i c l a d o * P U \_B r i t a \_R$

O preço unitário de cada material natural varia de acordo com a região. É importante avaliar as condições locais de mercado, sua localidade, proximidade de rios e praias, pois há casos onde o preço da areia natural, por exemplo, possuem um preço unitário mais elevado do que o da bica corrida. Neste modelo foi considerado o preço médio do agregado reciclado em Macaé, cujos valores iniciais estão mostrados na Tabela 5.8 . 
Tabela 5.8 - Tabela de preços médios de venda dos agregados reciclados em Macaé

\begin{tabular}{ll}
\hline Material & $\begin{array}{l}\text { Preço Médio de } \\
\text { Venda (R\$/t) }\end{array}$ \\
\hline Brita Reciclada & 35,00 \\
\hline Bica Corrida e & \\
Rachão & 25,00 \\
\hline \multicolumn{2}{c}{ Fonte: pesquisa de mercado (2012). }
\end{tabular}

Como no modelo anterior, a receita total bruta será a soma das receitas da venda de cada material reciclado e reaproveitado com a receita gerada da taxa de entrada na planta, fixada em 10,00 R \$/t com base no modelo 1. No caso da planta móvel, a taxa de entrada é cobrada também por tonelada processada.

A receita líquida que entrará no fluxo de caixa é a receita bruta do ano descontada dos impostos (Pis-Cofins e ICMS), que somados são aproximados $20 \%$.

\section{$\underline{\text { Lucros }}$}

O Lucro antes do Imposto de Renda (LAIR) é a diferença entre a receita líquida e a soma do custo total de reciclagem com a depreciação anual, que é proporcional ao investimento inicial e seu valor residual. Neste setor industrial o valor residual é considerado elevado, em média de $80 \%$.

O lucro líquido, portanto, será o LAIR descontado do Imposto de Renda (IR), fixado em $25 \%$ para este setor.

\section{Análise de viabilidade}

Segundo Motta, existem três ferramentas mais utilizadas para analisar a viabilidade econômica de um empreendimento: a taxa interna de retorno (TIR), o valor presente líquido (VPL), e payback. Neste software de simulação existem funções financeiras limitadas pré-embarcadas (built-ins), só foi possível analisar o valor presente líquido do investimento ao logo do tempo, cuja fórmula é:

$$
\mathrm{VPL}=\sum_{t=1}^{n} \frac{F C_{t}^{*}}{(1+i)^{t}}
$$

Onde $\mathrm{FCt}$ é a variação do fluxo de caixa no ano $\mathrm{t}$ (diferença entre receita líquida e custos no ano t) e i é a taxa de juros considerada. No modelo proposto foi 
considerada como taxa mínima de atratividade (TMA) de 8\% ao ano, comparados com a taxa Selic de 9\% ao ano no início de 2012.

A partir dos dados anteriores montou-se o fluxo de caixa no horizonte de 20 anos e determinou-se o VPL em seguida para cada cenário considerado.

\subsubsection{Cenários considerados}

Com a finalidade de avaliar o impacto apenas do tipo de planta e da qualidade na viabilidade da planta, foram estudados quatro cenários principais para a cidade de Macaé (RJ), conforme a tabela abaixo.

Tabela 5.9 - Cenários considerados na simulação do modelo de viabilidade econômica para a cidade de Macaé.

\begin{tabular}{llll}
\hline Cenário & Tipo de Planta & $\begin{array}{l}\text { Quantidade de } \\
\text { plantas }\end{array}$ & $\begin{array}{l}\text { Qualidade } \\
\text { \%alta - \%média }\end{array}$ \\
\hline 1 & Fixa & 1 & $0.17-0.83$ \\
\hline 2 & Móvel & 2 & $0.17-0.83$ \\
\hline 3 & Fixa & 1 & $0.5-0.5$ \\
\hline 4 & Móvel & 2 & $0.5-0.5$ \\
\hline \multicolumn{4}{r}{ Fonte: o autor. }
\end{tabular}

Pelo modelo anterior foi visto que o melhor custo-benefício era atingido taxa de entrada de 10,00R $\$ / t$, considerada constante neste modelo.

Apesar de a composição do RCD seguir uma variabilidade a cada projeto de reforma, demolição ou construção, seguindo uma distribuição de valores esperados, é sabido que este parâmetro não assume valores tão diferentes do que foi amostrado. Neste caso está sendo considerada a qualidade do RCD que efetivamente entra na planta de reciclagem. Uma política de autorização da entrada unicamente de caçambas que contenham uma proporção mínima de concreto, por exemplo, seria uma maneira de elevar o parâmetro de qualidade do RCD. Outra maneira seria a exigência legal ou estímulos a processos de construção e demolição seletiva dos quais os resíduos de melhor qualidade fossem acumulando em caçambas e seriam os únicos autorizados a ser encaminhados para as usinas de reciclagem. 


\subsubsection{Resultados}

Os resultados das simulações são mostrados nos dois gráficos abaixo. O primeiro representa o Lucro antes do Imposto de Renda (LAIR) gerado anualmente para cada cenário (Figura 5.18). Observa-se que devido a maior escala e maior valor agregado dos produtos, a planta com circuito maduro é a que apresenta maior lucro. Os custos superam as receitas iniciais em todos os casos, explicando os prejuízos nos primeiros anos. Os dados referentes às plantas móveis apresentam um comportamento mais linear a partir do oitavo ano, quando atingem sua capacidade máxima de reciclagem.

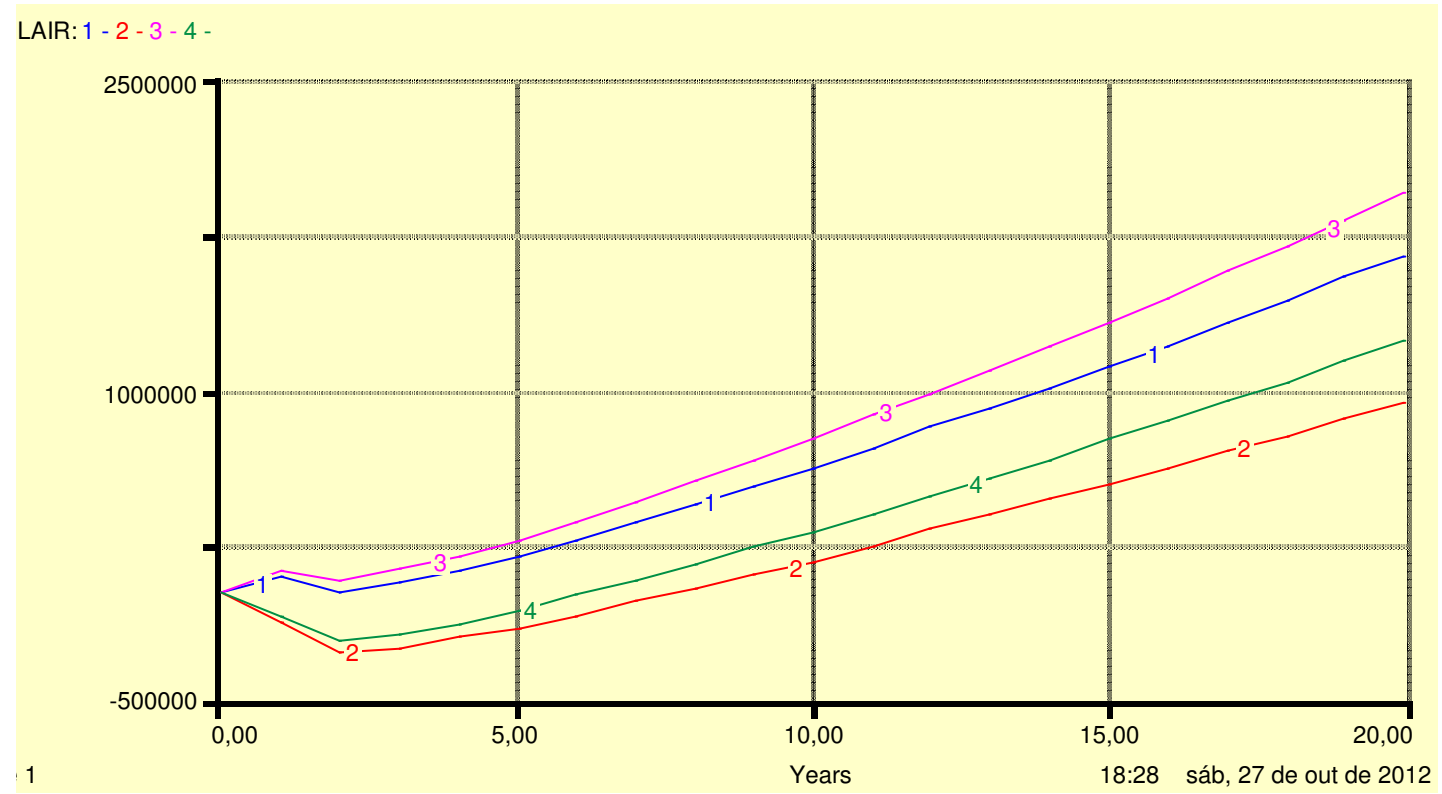

Figura 5.18 - Lucro anual antes do Imposto de Renda para cada um dos cenários considerados na cidade de Macaé

Apesar de as plantas móveis apresentarem menores investimentos iniciais e as fixas maiores lucros líquidos, ambos apresentam valores de VPL muito próximos. Em nenhum dos casos foi apresentado VPL positivo antes do vigésimo ano (Figura 5.19Erro! Fonte de referência não encontrada.). Nos dois cenários de qualidade nas plantas móveis apresentaram VPLs maiores do que as fixas, mas ainda inviável economicamente. 
VPL: 1 - 2 - 3 - 4 -

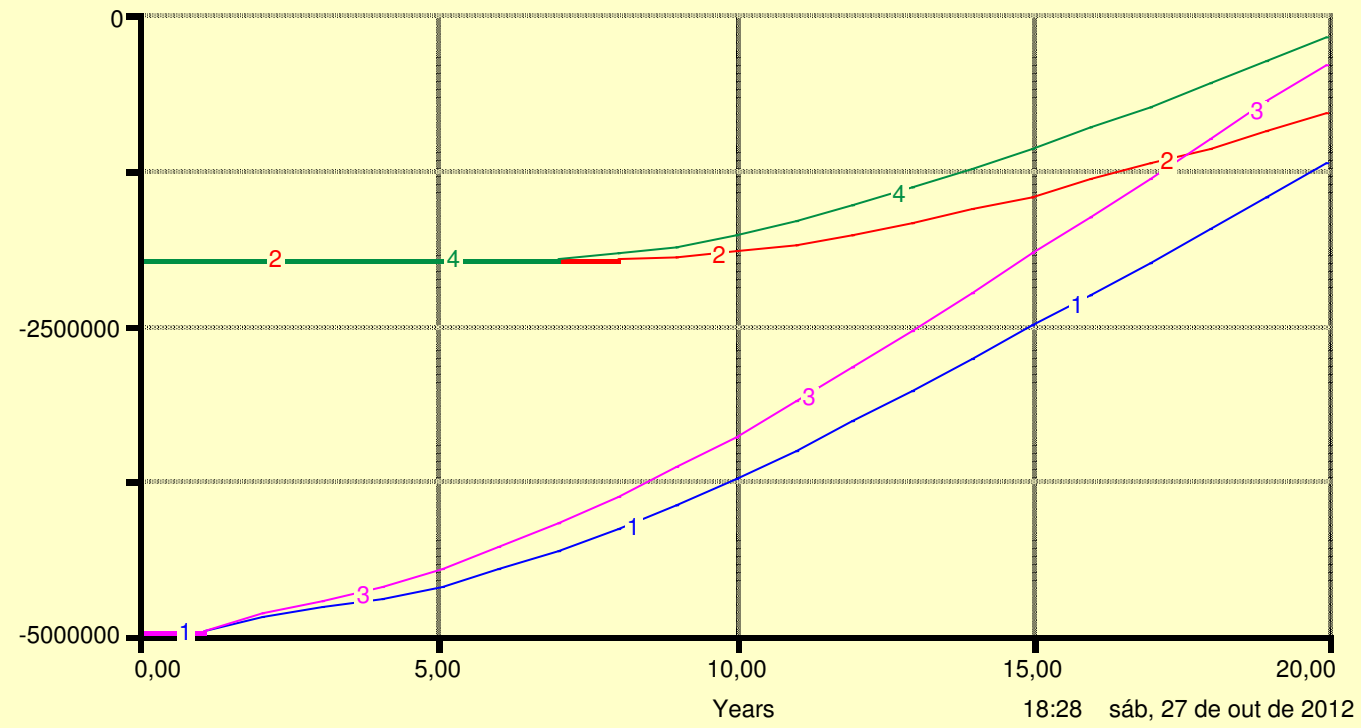

Figura 5.19 - Valor Presente Líquido em cada cenário em Macaé.

No entanto percebe-se que para melhores padrões de qualidade, ambas as plantas apresentaram resultados bem melhores (Tabela 5.10), sendo o quarto cenário (planta móvel, com melhores qualidades) o que apresentou VPL menos negativo. Ou seja, caso a planta móvel só escolha locais onde haja grandes demolições de estruturas como pontes, grandes construções, este seria o mais indicado.

Tabela 5.10- VPL e Payback dos resultados simulados.

\begin{tabular}{lll}
\hline Cenário & VPL (t=20anos) & Payback(anos) \\
\hline 1 & $-R \$ 1.219 .873,65$ & - \\
\hline 2 & $-R \$ 800.152,65$ & - \\
\hline 3 & $-R \$ 403.928,27$ & - \\
\hline 4 & $-R \$ 193.136,88$ & - \\
\hline
\end{tabular}

Percebe-se que, também como o comprovado no primeiro modelo, as plantas necessitarão de subsídios para se tornarem viáveis. A melhoria da composição tem grande impacto na viabilidade, mas não é suficiente. Por isso, no próximo tópico serão propostas maneiras de solucionar a viabilidade das plantas de reciclagem, sem levar mais em conta a questão da qualidade.

\subsubsection{Propostas de solução da viabilidade da reciclagem em Macaé}

Uma vez que já ficou evidente que a adoção de medidas que elevam o percentual da qualidade do RCD que entra nas plantas de reciclagem é uma maneira de melhorar sua viabilidade econômica, a seguir serão simulados outras maneiras de 
viabilizar em um cenário da qualidade atual de Macaé. Neste sentido, alguns subsídios podem ser pensados: redução da carga tributária para esse tipo de negócio, que, ao todo, paga $45 \%$ de imposto; redução do valor do terreno adquirido, considerado o maior componente dos custos iniciais; incentivos que estimulem ou exijam o uso dos agregados reciclados em construções futuras, aumentando o percentual reciclável e as receitas.

Dentre essas medidas, as referentes ao valor do terreno, impostos e tipo de planta foram consideradas nas simulações. Simulou-se o impacto da diminuição do ICMS, Pis e Confis na viabilidade das plantas, bem como a aquisição do terreno a $50 \%$ do seu valor original previsto na Tabela 5.6 (a 1.5milhões ao invés de 3 milhões) deste capítulo, proporcionando um menor investimento inicial, como mostrado nos seis cenários considerados na Tabela 5.11

Tabela 5.11 - Cenários das propostas de solução para a viabilidade das plantas com circuito emergente em Macaé

\begin{tabular}{lllllll}
\hline Cenário & $\begin{array}{l}\text { Tipo de } \\
\text { Planta }\end{array}$ & \multicolumn{1}{c}{ Impostos } & $\begin{array}{c}\text { Valor do } \\
\text { terreno (R\$) }\end{array}$ & \multicolumn{1}{c}{ VPL } & \multicolumn{1}{c}{$\begin{array}{c}\text { Payback } \\
\text { (anos) }\end{array}$} \\
\hline 1 & Fixa & $15 \%$ & 3 milhões & $-\mathrm{R} \$ 653.617,35$ & - \\
\hline 2 & Fixa & $10 \%$ & 3 milhões & $-\mathrm{R} \$ 87.361,04$ & - \\
\hline 3 & Fixa & $5 \%$ & 3 milhões & $\mathrm{R} \$ 478.895,27$ & 17,4 \\
\hline 4 & Fixa & $20 \%$ & 1,5 milhões & $\mathrm{R} \$ 230.107,60$ & 18,2 \\
\hline 5 & Móvel & $15 \%$ & - & $-\mathrm{R} \$ 389.928,75$ & - \\
\hline 6 & Móvel & $10 \%$ & - & $\mathrm{R} \$ 49.876,24$ & 19,3 \\
\hline
\end{tabular}

Pode-se perceber que a redução dos impostos só são suficientes quando atingem o valor de $5 \%$ para as plantas fixas e $10 \%$ para as plantas móveis. A viabilidade é mais sensível ao valor do terreno nas plantas fixas. O cenário em que se obteve o melhor desempenho financeiro foi o 3. Uma combinação desses elementos pode ser também pensada, visto que alguns investidores podem não aceitar paybacks muito longos. 


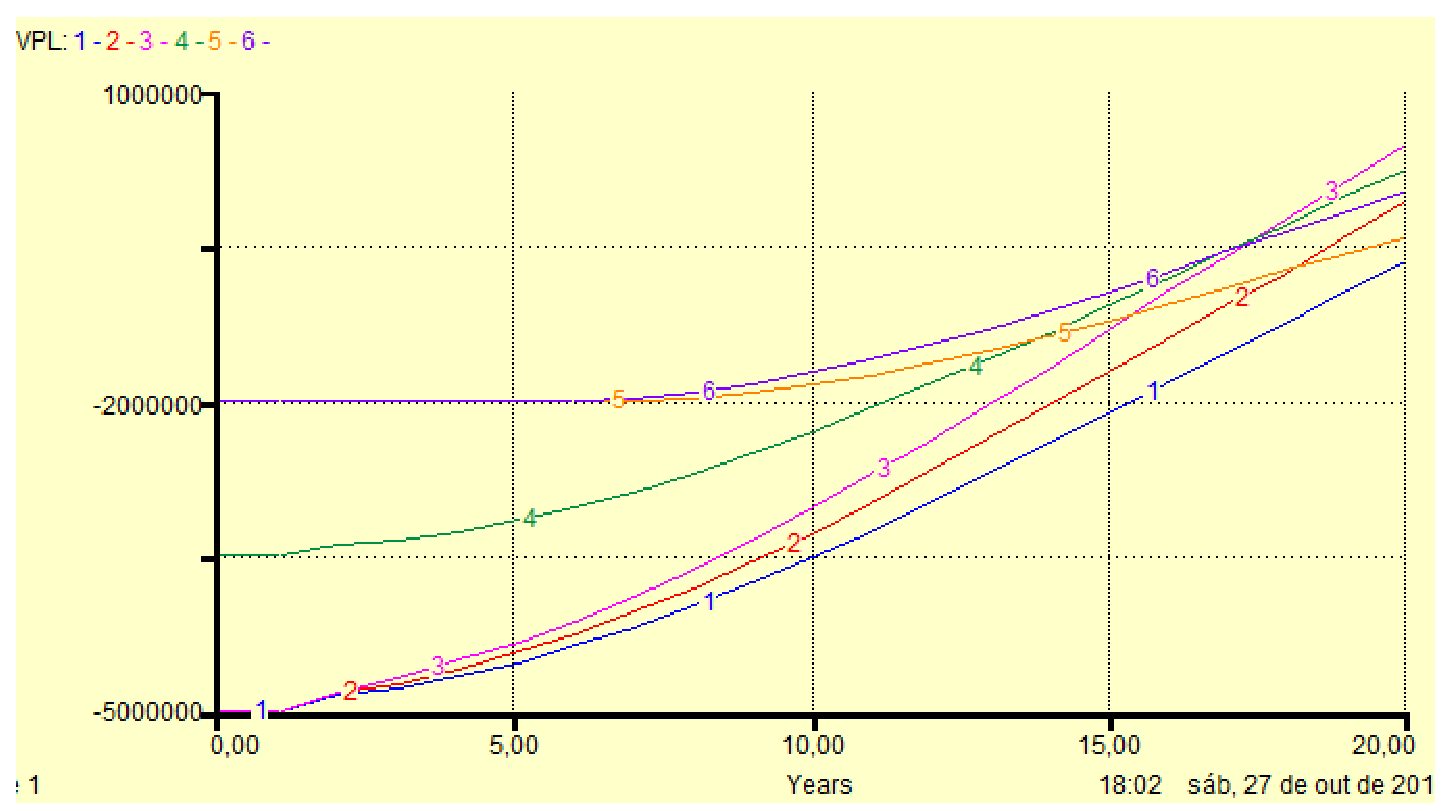

Figura 5.20 - Resultado do VPL simulado com redução de imposto e terreno para as plantas fixas e móveis em Macaé.

Com esses resultados, fica evidente a importância dos subsídios para o setor de reciclagem em plantas fixas e móveis de cidades com pouca geração de RCD e baixo estímulo à reciclagem. $\mathrm{O}$ custo do terreno em cidades pode representar até $80 \%$ do investimento inicial, principalmente neste momento de valorização imobiliária na região, assumindo um papel importante para a viabilidade destes empreendimentos. Uma elevada carga tributária também compromete. A qualidade do RCD que entra na planta é um importante diferenciador de margem obtidas. Como no modelo anterior, fica a questão: quem pagará por esses subsídios? De que maneira as empresas receberão o subsídio?

É válido ressaltar que as relações de causa e efeito em ambos os modelos foram baseadas em estimativas a partir de visitas e dados colhidos de questionários e pesquisas de mercado. Não estão sendo consideradas suas distribuições de probabilidade para simplificar a modelagem. É necessário, portanto, um acompanhamento do desempenho dessas organizações a cada ano. Uma constante atualização dos valores de entrada também é importante a fim de obter uma melhor calibragem dos modelos propostos. 


\section{CONCLUSÕES E SUGESTÕES DE NOVOS ESTUDOS}

"Agora, este não é o final. Não é mesmo o começo do final. Mas é, talvez, o final de um começo" 
A primeira pergunta formulada ao iniciar este trabalho foi o motivo pelo qual a resolução Conama 307 de 2002 não produziu o resultado esperado, embora fosse um sistema lógico, de fácil entendimento e aparentemente factível. A primeira conjectura aconteceu na visita técnica realizada na Usina de Reciclagem de Macaé, em 2003, a qual produzia reciclados e artefatos, quando o responsável disse-nos que, além da contabilidade econômica, a Prefeitura usava uma contabilidade ambiental e social. Isto é, havia uma prioridade da gestão adequada dos RCD por vontade política eventual.

A resposta veio claramente no trabalho de Nunes,K.R.A., 2004, em que mostra, após minucioso levantamento de dados e análise financeira dos investimentos, que não era viável o sistema em vigor.

Comparando os dados do PNSB 2000 e de 2008, constata-se que, na última pesquisa, 309 municípios faziam algum tipo de processamento do $R C D$, o que seria pouco relativamente, mas, em número absoluto, nada desprezível. As pesquisas mostram que a principal vulnerabilidade da gestão no Saneamento Básico estava na emissão de efluentes (esgotos) e na existência dos chamados lixões como aterro de resíduos sólidos urbanos em geral. O RCD como resíduo inerte não seria a prioridade do sistema público nesta área de gestão ambiental, conforme ocorreu nestes últimos anos.

Formulada uma segunda pergunta: o que tinha ocorrido realmente nesta área, neste período, em termos econômicos? Encontrou-se a resposta nos economistas clássicos através do conceito de processo de criação de valor, quase-mercadoria e mercado nascente. $O$ que de fato ocorrera foi a formação de um mercado de agregados reciclados através da valorização dos resíduos como matéria-prima de segunda linha para a produção destes reciclados. Inclusive a Resolução 307/2002 pode ser entendida como um marco legal que confere valor aos resíduos de classe $A$ e $B$, dispondo que estes deviam ser reciclados ou guardados em aterros para uso posterior. Ou seja, quem recicla ou guarda algo o faz porque tem valor.

Por sua vez, a mercadoria agregado reciclado e o mercado destes produtos são uma construção econômica e social de médio e longo prazo. O dominante na produção de agregados era a empresa pública ou concessionária. Não havia um mercado praticando preços de compra dos insumos e venda dos produtos. Inclusive 
os trabalhos de viabilidade econômica financeira citados trabalhavam com preços referenciados a diferença entre natural e reciclado praticados nas industrias recicladoras maduras. Hoje podemos consultar as recicladoras em relação ao preço da brita e da areia recicladas.

$\mathrm{Na}$ gestão dos resíduos de construção e demolição, o foco do saneamento básico mudou para a valorização dos mesmos.

O conjunto das empresas e mesmo autarquias que realizavam processamento dos RCD eram ligados aos serviços públicos municipais, mas foram nascendo, a partir da metade da década, uma série de empresas de caráter privado e ligadas à cadeia da construção civil nos núcleos urbanos, onde a oportunidade de montar empresas recicladoras surgiu por vários fatores que precisam ser objeto de pesquisa posterior. Destaca-se o aumento do custo do descarte para os RCD da construção civil, principalmente os vinculados ao transporte dos resíduos como um dos mais decisivos para a implantação destas recicladoras.

O processo de formação do mercado e a constituição das empresas acima fazem parte de um mesmo movimento no sentido de criar um novo setor industrial distinto ao qual foi denominado a indústria recicladora emergente.

O sistema em vigor na gestão dos Resíduos Sólidos apresentava sinais de fadiga, não melhorando os índices ambientais quando em 2010, através da lei 12.305, mudou-se o marco regulatório do Comando e Controle para o paradigma do Poluidor-Pagador, instituindo a responsabilidade compartilhada sobre a gestão dos RCD.

Este paradigma permite à governança ambiental usar instrumentos econômicos para a gestão dos RCD como subsídios, redução de impostos, parcerias público-privadas.

Estes instrumentos econômicos vão atuar no núcleo dinâmico da indústria recicladora emergente e o setor público hoje preponderante vai diminuir sua participação na reciclagem e na gestão dos RCC. Fazendo analogia com a mineração constituída de empresas que buscam valorizar o estoque mineral através dos processos de tratamento e beneficiamento dos minérios, foi cunhada a denominação de mineradoras urbana para estas recicladoras. Por esta razão, o 
título deste trabalho em que se estuda esta formação que origina um novo sub-setor industrial dentro da indústria da construção civil.

Por sua vez, a indústria recicladora nascente acelera o processo de acumulação de condições para formação de um mercado de agregados reciclados, oferecendo novos produtos. A cada nova visita técnica nas recicladoras, percebia-se um novo agregado sendo produzido e basta verificar os sites das empresas, por exemplo, filiadas a ABRECON para constatar a diversificação da oferta.

No capítulo III fez-se uma avaliação da trajetória desta indústria emergente em relação a indústria recicladora madura, com o pressuposto que, no longo prazo, a emergente vai se mover na direção da fronteira tecnológica e da qualidade dos produtos existente nas maduras. A conclusão é que o salto de qualidade está na alimentação dos resíduos segregados na origem através da demolição e da coleta seletiva. Este movimento para ser sustentável para a cadeia da construção civil requer estudos de viabilidade sistêmica destas práticas, porque os custos adicionais devem ser compensados por uma oferta de reciclados cujo mix com os naturais diminuem na proporção deste aumento de custos da demolição e da coleta seletiva.

No capítulo IV foi possível verificar os diferentes processos de urbanização, em alguns casos se desenvolveram com a industrialização completa desde a leve até a pesada, através da grande indústria como o que ocorreu em São Paulo (concreto $49 \%$ ) e no outro extremo Maceió (concreto 4\%) com a urbanização, por meio da agroindústria da cana de açúcar. Curioso é o índice de Macaé (concreto 17\%), que pertenceu a Campos e foi urbanizada devido ao escoamento do açúcar no passado, e com quinze anos da instalação da indústria pesada do petróleo, ficou na posição intermediária. Estas diferentes densidades para o RCD médio destas cidades configura uma enorme heterogeneidade da qualidade do RCD das cidades amostradas.

No capítulo V, a partir das modelagens, foi possível concluir que:

Pelo Modelo Custo-Benefício:

- Apesar dos altos investimentos iniciais com a aquisição de terrenos, construção da planta e compra de equipamentos, a reciclagem do RCD apresentou mais benefícios do que custos nas três cidades. Em um horizonte de 20 anos, a 
região de São Paulo onde foi amostrada apresentaria uma relação custobenefício bem superior às cidades de Macaé e Maceió, que também apresentaram relações positivas. Esse é um indicador de que a reciclagem, em todas as cidades estudadas, deve ser recomendada e incentivada.

- No entanto, não basta investir na infraestrutura, na logística ou nas próprias plantas de reciclagem. É preciso que mecanismos de formação de mercado sejam desenvolvidos, como por exemplo, políticas de compras de agregados reciclados para obras públicas.

- Devido a condições de mercado mais favoráveis, como maior geração de RCD, maiores preços de venda dos agregados reciclados, a região de São Paulo seria a única capaz de devolver todo o subsídio recebido antes dos 20 anos considerados. Já as cidades de Macaé e Maceió conseguiriam retornar apenas parte dos 6 milhões que ambas receberiam, restando ainda, cerca de 2 milhões e 3 milhões, respectivamente.

- Devido à baixa velocidade da reciclagem, à elevada quantidade de irregularidade e menores preços de venda de agregados reciclados, só após 13 anos a planta na cidade de Maceió passaria a gerar mais receita do que custo e mesmo em 20 anos, os subsídios não poderiam ser cancelados. Na cidade de Macaé, com menor quantidade de RCD gerada, esse intervalo para superação das receitas sobre os custos seria de 11 anos.

- O modelo mostrou-se consistente no sentido que as projeções das trajetórias no tocante a Custo-Benefício mais favorável na ordem São Paulo-MacaéMaceió foram sinalizadas nos capítulos antecedentes, tanto na maior complexidade da organização industrial da construção civil como na amostragem destes municípios.

Depois de amostragens nas três cidades para investigar a composição dos seus respectivos RCD, foi proposto um Modelo de Viabilidade para a cidade de Macaé, a partir das qualidades do RCD da cidade. Foram avaliados 2 tipos de qualidade ("alta" e "média/baixa"), além de em 2 tipos de plantas (fixas e móveis). Cada um com seus respectivos investimentos iniciais, custos fixos e variáveis. O modelo foi calcado na realidade brasileira, com produtos como rachão, bica corrida e também brita reciclada. Os resultados mostram que: 
- O principal fator de plantas fixas apresentarem maiores investimentos iniciais consiste, principalmente, da necessidade de aquisição de grandes terrenos.

- Em Macaé, a implantação de uma planta fixa ou duas plantas móveis só serão viáveis com auxílio de subsídios.

- Para as plantas fixas, estes subsídios podem ser representados na forma de parceria público-privada, os quais reduzam o valor de aquisição do terreno em $50 \%$, que em algumas cidades pode representar até $80 \%$ dos custos iniciais. Outra maneira de subsidiar seria reduzindo de $20 \%$ para $5 \%$ a incidência dos impostos como ICMS, Pis,Cofins. Já para as plantas móveis, esta redução de impostos precisaria ser de, no mínimo 10\%.

- Ações que buscam a melhoria da composição do RCD que entra nas plantas de reciclagem, como demolição seletiva, têm grande impacto na viabilidade, mas não é suficiente.

- As variáveis de maior impacto sobre a viabilidade são: o volume de investimento inicial, os impostos incidentes, os custos operacionais e os preços dos agregados reciclados no mercado.

\subsection{CONSIDERAÇÕES FINAIS}

Os modelos propostos sinalizam para os municípios que no momento estão definindo a gestão do RCD na sua área de jurisdição ou em acordos regionais que as condições negociais de gestão a este nível irão provocar um realinhamento dos preços dos agregados reciclados, possibilitando lucros a longo prazo para as empresas recicladoras. O aumento da qualidade dos produtos destas empresas provocará ganhos de escala para a cadeia da construção civil, abrindo mercado para areia e brita recicladas com valor agregado maior que os agregados usados para a pavimentação.

O formato da indústria recicladora emergente com o núcleo empreendedor privado irá se difundir doravante na indústria da construção civil. É preciso entender sua dinâmica através de novas pesquisas. Foi indicada sua trajetória, mas não há elementos para afirmar o tempo necessário para o salto para a maturidade. 


\section{REFERÊNCIAS}

ÂNGULO, S.C. et al. Análise comparativa da tecnologia de processamento na reciclagem da fração mineral dos resíduos de construção e demolição. In: XXI ENCONTRO NACIONAL DE TRATAMENTO DE MINÉRIOS E METALURGIA EXTRATIVA, 2005. Natal: CEFET/RN, p. 305-312, 2005.

. Caracterização de agregados de resíduos de construção e demolição reciclados separados por líquidos densos. In: I Conferência Latino-americana de Construção Sustentável - $\mathrm{X}$ encontro nacional de tecnologia do Ambiente Construído, Anais, São Paulo, 2004.

- Desenvolvimento de novos mercados para reciclagem massiva de RCD. In: V SEMINÁRIO DE DESENVOLVIMENTO SUSTENTÁVEL E RECICLAGEM NA CONSTRUÇÃO CIVIL, Ibracon, São Paulo, 2002.

. Metodologia de caracterização de resíduos de construção e demolição. In: VI SEMINÁRIO DE DESENVOLVIMENTO SUSTENTÁVEL E A RECICLAGEM NA CONSTRUÇÃO CIVIL. São Paulo: IBRACON CT-206/IPEN, Anais, 2003.

ÂNGULO,S.C.,JOHN,V.M.. Variabilidade de agregados graúdos de resíduos de construção e demolição reciclados : In. Boletim Técnico da Escola Politécnica, Departamento de Engenharia da Construção Civil, BT/PCC/279. EPUSP 2001

BELL, D. The coming of post industrial society. Nova lorque: Basic Books, 1973.

BLENGINI, G.A. Life cycle of building, demolition and recycling potential: a case study in Turin, Italy. Building and Environment v. 44, p. 319-330, 2009.

BRASIL. Conselho Nacional do Meio Ambiente. Resolução 307/2002. . Instituto Brasileiro de Geografia e Estatística, 2008. . Instituto Brasileiro de Geografia e Estatística, 2011. 
. Lei no 9.065, de 12 de fevereiro de 1998. Dispõe sobre as sanções penais e administrativas derivadas de condutas e atividades lesivas ao meio ambiente. Brasília.

. Lei no 11.445 , de 5 de janeiro de 2007. Estabelece diretrizes nacionais para o saneamento básico. Brasília.

. Lei 12.305, de 2 de agosto de 2010. Institui a Política Nacional de Resíduos Sólidos. Brasília.

. Superintendência de Limpeza Urbana. Programa global para otimização da disposição e da coleta e reciclagem de resíduos da construção em Belo Horizonte. Belo Horizonte, 1993.

CALÔBA,G.M.; MOTTA R.R. Análise de Investimentos. Atlas, 2002.

CARRIJO, P.M. Análise da influência da massa específica de agregados graúdos provenientes de resíduos de construção e demolição no desempenho mecânico do concreto. São Paulo: USP, 2005. Dissertação (Mestrado em Engenharia Civil), Escola Politécnica, Universidade de São Paulo, São Paulo, 2005.

CHAVES, A. "Teoria e prática do Tratamento de Minérios" 4 ed. Editora Signus, 2002.

CHUNG S. e LO, C. Evaluating sustainability in waste management: the case of construction and demolition,chemical and clinical wastes in Hong Kong. Resources, Conservation \& Recycling, v. 37, 2003.

CRAIGHILL, A.; POWELL, J.C. A lifecycle assessment and evaluation of construction and demolition waste. Reino Unido: CSERGE, 1999. ISSN 09678875.

$\operatorname{COSTA}, N$. et al. Planejamento de programas de reciclagem de resíduos de construção e demolição no Brasil: uma análise multivariada. vol.12, n.4, p. 446456, 2007. 
COSTA, L. et al. Separação densitária de britas de resíduos de construção e demolição (RCD) por jigue. Anais do XXIIIENTME, Encontro Tratamento de Minérios, Gramado/RS, 2009.

CRAIGHILL,A.; POWELL,J. A lifecycle assessment and evaluation of construction and demolition waste. Centre for Social and Economic Research on Global Environmental. CSERGE, U.K. 1999

DOLAN et al. Concepts for reuse and recycling of construction and demolition waste. EUA: Construction Engineering Research Laboratories, US Army Corps of Engineers, 1999.

DURAN, X.; LENIHAN, H.; O'REGAN, B. A model for assessing the economic viability of construction and demolition waste recycling: the case of Ireland. Resources, Conservation and Recycling, v. 46. 2006.

FERHR, M.; MARQUES, R.B.; PEREIRA, A.F.N. Polluter-pays principle applied to construction and demolition debris. Journal of Environmental Protection, abr., v.2, p. 124, 2011.

HAO, J.L.L.; TAM, V.W.Y.; YUAN, H.P. Dynamic modeling of construction and demolition waste management process. v. 17, n. 5. Shenzhen: Emerald Group Publishing Limited, 2010.

JADOVSKI, I. Diretrizes técnicas e econômicas para usinas de reciclagem de resíduos de construção e demolição. 2005. 178 p. Dissertação (Mestrado) Escola de Engenharia, Universidade do Rio Grande do Sul. Rio Grande do Sul, 2005.

JOHN, V. Aproveitamento de resíduos sólidos como materiais de construção. In: Reciclagem de entulho para a produção de materiais de construção: Projeto Entulho Bom. Salvador: EDUFBA, p. 26-44, 2001.

LAGE, I.M. et al. Estimation of the annual production and composition of C\&D debris. Texas: Waste Management, n. 30, p. 636-645, 2010. 
LUPPI B.;PARISI,F.;RAJAGOPALAN,S.- The rise and the fall of the polluter-pays principle in developing countries. International Review of Law and Economics 32, p. 135-144, 2012.

Marshall,R.;Farahbakhsh,K.- Systems approaches to integrated solid waste management in developing countries. Waste Management 33. p. 988-1003,2013.

MELLO, J. M.C. O CAPITALISMO TARDIO. Ed. Brasiliense, 1984.

MOREIRA, L. H. Avaliação da influência da origem e do tratamento dos agregados reciclados de RCD no desempenho mecânico do concreto estrutural. Tese Mestrado na Engenharia Civil da EP da USP 2010.

MÜELLER, A. Closed loop of concrete rubble? In: VII SEMINÁRIO DE DESENVOLVIMENTO SUSTENTÁVEL E RECICLAGEM NA CONSTRUÇÃO CIVIL. São Paulo: Instituto Brasileiro do Concreto, 2006.

NAGATAKI, S. et al. Assessment of recycling process induced damage sensitivity of recycled concrete aggregates. Cement and Concrete Research, v. 34, p. 965-971. 2004.

NASCIMENTO, R. Produção de areia reciclada lavada de resíduos classe A da construção civil: Contribuição ao desenvolvimento de processo via úmida na Usina de Socorro/SP. Dissertação (Mestrado), EPUSP, São Paulo, 2006.

NUNES, K.R.A.. Avaliação dos Investimentos nas Usinas de Reciclagem de RCC nos Municípios Brasileiros. Tese Doutorado na Engenharia de ProduçãoCOPPE-RJ 2004.

NUNES, K.R.A. et al. Evaluation of Investments in Recycling Centres for Construction and Demolition Wastes in Brazilian Municipalities. 2007. p. 15311540.

ACV de alternativas para manejo e destinação de resíduos da construção civil na cidade do Rio de Janeiro. In: 2ํㅡㄹ Congresso Brasileiro em Gestão de Ciclo de Vida de Produtos e Serviços. Florianópolis: 2010. 
PANORAMA 2010. Associação Brasileira de Empresas de Limpeza Pública e Resíduos Especiais. São Paulo, Brasil, 2010.

PEARCE, D. Cost-benefit analysis and environmental policy. Oxford Review of economic policy, v.14, n.4. 1998.

PETERSEN, L.; MINKKINEN, P.; ESBENSEN, K. H. Representative Sampling: Theory of Sampling. Chemometrics and intelligent laboratory systems, v. 77, p. 261277, 2005.

PINTO, T.P. Metodologia para a Gestão Diferenciada de Resíduos Sólidos da Construção Urbana. 1999. 190 p. Tese (Doutorado) - Escola Politécnica, Universidade de São Paulo, São Paulo, 1999.

POON, C.S. et al. On-site sorting of construction and demolition waste in Hong Kong. Resources, conservation and recycling, v. 32. p. 157-172. 2001.

TAM, V.W.Y. Comparing the implementation of concrete recycling in the Australian and Japanese construction industries. Journal of Cleaner Production, v. 17 , n. 7, p. 688-702. 2009.

TRÄNKLER, J.; WALTER, I.; DOHMAN, M. Environmental impact of demolition waste-an overview on 10 years of research and experience. WASTE MANAGEMENT. v. 16, p. 21-26. 1996.

; AGOPYAN, V. Reciclagem de resíduos da construção. In: SEMINÁRIO DE RECICLAGEM DE RESÍDUOS SÓLIDOS DOMICILIARES.1999 p. 2-13.

ULSEN, C. Caracterização e separabilidade de agregados miúdos produzidos a partir de resíduos de construção e demolição. Escola Politécnica da USP, Tese de Doutorado, São Paulo, 2011.

YUAN et al. A model for cost-benefit analysis of construction and demolition waste management throughout the waste chain. Resources, Conservation and Recycling: v. 55. 2011. 
ZHAO, W., REN, H., ROTTER, V.S. A system dynamics model for evaluating the alternative of type in construction and demolition waste recycling center: the case of Chongqing, China. Resources, Conservation and Recycling, n. 55, p. 933944. 2011.

ZHAO, W., REN, H., ROTTER, V.S. Evaluation of the economic feasibility for the recycling of construction and demolition waste in China - The case of

Chongqing. Resources, Conservation and Recycling, n. 54, p. 377-389. 2010.

\section{APÊNDICE A - PROCESSAMENTO}

As etapas de processamento a seguir demonstram o esforço da pesquisa experimental para obter os melhores produtos com as melhores práticas para os resíduos mistos das três cidades. Não tem relevância direta para os resultados do meu trabalho. Mas adquiriram uma importância porque foram um contraponto na nossa investigação porque que entendemos que os principais obstáculos no tocante a viabilidade da reciclagem estão na gestão dos resíduos e que uma maior eficiência das operações unitárias reside na alimentação das plantas.

Foram realizados ensaios de catação em pilha e esteira, britagem em britador de mandíbulas e impacto e foram construídas curvas de lavabilidade obtidas em jigue piloto de bateladas e jigue industrial ambos equipamentos da All Mineral de Duisburg/Alemanha.Ver (Costa, Lauro et al., Entmee 2009) As britas obtidas foram testadas para desempenho mecânico em concretos na tese (Moreira, Lucia H. H, Poli) com resultados satisfatórios para SP e Macaé mas não foram realizados para a cidade de Maceió. Estas britas foram retiradas de lotes de qualidade superior através dos testes do sink and float. As curvas de "lavabilidade" do jigue de 
descontínuo mostram os resultados compatíveis coma a amostragem das cidades mas as curvas de lavablidade do jigue industrial não se mostraram compatíveis devido a indefinição das curvas. Conforme salientamos anteriormente a jigagem na industria recicladora madura é realizada com material homogêneo para separar leves, isto é a proporção entre flutuado e afundado é mínima.

Inicialmente, foi avaliada a eficiência de catação para lotes agrupados em função do teor de contaminantes para as três cidades, segundo três procedimentos distintos. Em seguida, alguns lotes foram agrupados segundo o critério de qualidade a partir da distribuição da densidade, definindo-se grupos de Alta, Média e Baixa Qualidade, para cada cidade. Cada um dos nove grupos foi processado em diferentes layouts de cominuição a fim de se definir a melhor rota de processamento e avaliar a qualidade dos agregados reciclados obtidos.

\section{A.1 INFLUÊNCIA DOS DIFERENTES PROCEDIMENTOS DE CATAÇÃO NA DESCONTAMINAÇÃO DOS LOTES DE RCD}

Os teores de materiais orgânicos e de contaminantes (gesso e cimento amianto) foram analisados nas diversas frações granulométricas graúdas (> 4,8 mm).

Lotes com diferentes teores de materiais orgânicos foram agrupados, definindo três níveis de contaminação (mínimo, médio e máximo). Três diferentes procedimentos de catação foram simulados:

a) Sobre uma pilha cônica (prática em usina nacional);

b) Sobre uma área (prática em usina nacional);

c) Sobre esteira após o escape da fração em grelha de 50,00 mm (baseado nos resultados de caracterização).

A recuperação de massa, antes e após a operação de catação, foi comparada para se definir qual a operação de triagem mais eficiente. 
Os resultados para o procedimento c) constituiu-se as melhor prática para catação

Etapa 1

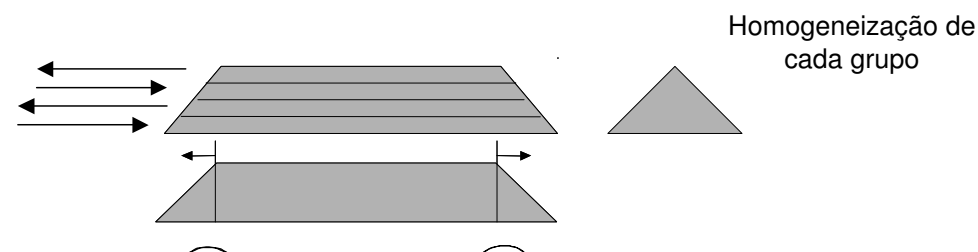

\section{Etapa 2}

\section{Etapa 3}

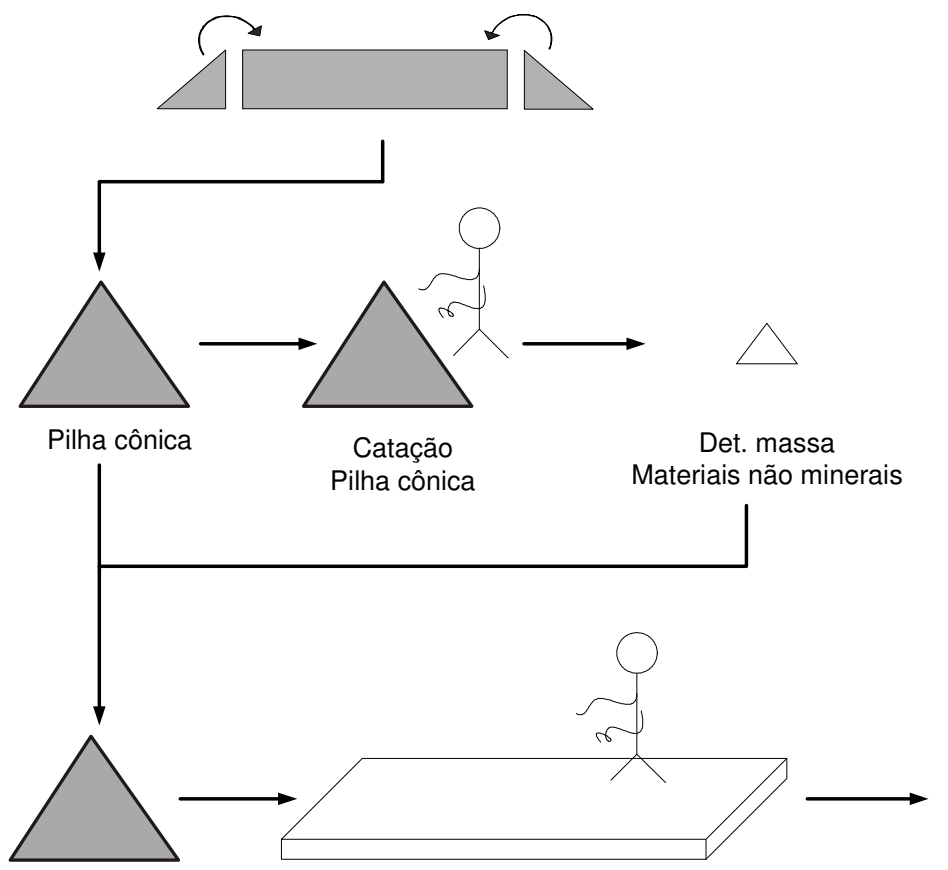

Pilha cônica

Distribuição da pilha

Det. massa

numa área e catação

Materiais não minerais

Etapa 4

Grelha vibratoria
$25.4 \mathrm{~mm}$
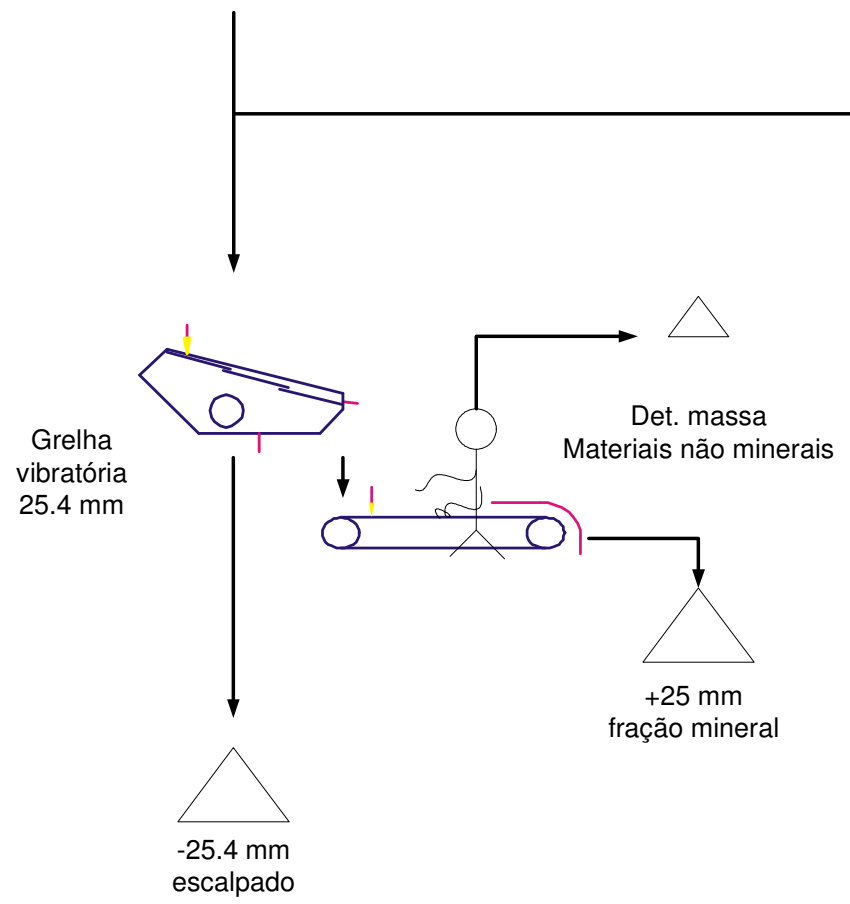

Figura A.1 - Etapas de processamento. 


\section{A.2 INFLUÊNCIA DO TIPO DE BRITAGEM E DA ORIGEM NA QUALIDADE DO AGREGADO GRAÚDO DE RCD}

O objetivo foi melhorar a qualidade do agregado reciclado graúdo através do processamento e avaliar as possibilidades de utilização deste em concretos.

A utilização de dois estágios de britagem é usual em usinas de processamento da fração mineral de RCD no contexto nacional e mundial (Ângulo et al., 2005; Muller, 2003; Nagataki et al., 2004). A britagem, além de fundamental para adequação e distribuição granulométrica, também exerce papel essencial para a melhoria da qualidade do agregado reciclado para concreto estrutural, já que contribui para liberação da pasta de cimento porosa aderida ao agregado natural (alta porosidade implica em redução na resistência mecânica). Dois mecanismos de britagem secundária e um ajuste granulométrico foram investigados.

\section{Britagem por impacto e por mandíbula}

A Tabela A.1 apresenta as variáveis do estudo de britagem, bem como o efeito esperado e propriedades analisadas no produto. Para o estudo, os lotes foram compostos em três diferentes grupos de qualidade, segundo o critério de distribuição de densidade: Alta Qualidade (AQ), Média Qualidade (MQ) e Baixa Qualidade (BQ).

Tabela A.1 - Dados do estudo de britagem.

\begin{tabular}{|c|c|c|}
\hline Variáveis & $\begin{array}{l}\text { Efeitos no agregado } \\
\text { graúdo reprocessado }\end{array}$ & Propriedades avaliadas \\
\hline $\begin{array}{l}\text { Britagem por mandíbula em } \\
\text { circuito fechado }(-25,4 \mathrm{~mm}) \text { e } \\
\text { peneiramento a seco }(4,8 \mathrm{~mm})\end{array}$ & \multirow{2}{*}{$\begin{array}{c}\text { Adequar a distribuição } \\
\text { granulométrica como } \\
\text { agregado graúdo } \\
\text { Gerar uma brita com menor } \\
\text { porosidade }\end{array}$} & \multirow{2}{*}{$\begin{array}{c}\text { Distribuição } \\
\text { granulométrica } \\
\text { Distribuição de densidade } \\
\text { Propriedades físicas } \\
\text { Teor de pasta de cimento } \\
\text { Teor de finos }\end{array}$} \\
\hline $\begin{array}{c}\text { Britagem por impacto em } \\
\text { circuito fechado }(-25,4 \mathrm{~mm}) \mathrm{e} \\
\text { peneiramento a seco }(4,8 \mathrm{~mm})\end{array}$ & & \\
\hline
\end{tabular}

\section{Definição dos circuitos fechados de britagem}

O ajuste granulométrico (tamanho das partículas) é essencial para garantir a possibilidade da utilização do agregado reciclado em atividades de construção. Para 
tal, o RCD amostrado foi britado em circuito fechado com peneira de abertura 25,4 $\mathrm{mm}$ em dois tipos distintos de britadores (de mandíbulas e impacto). A britagem foi realidade para cada um dos grupos de qualidade e para cada um dos RCD, das três diferentes origens (Macaé, São Paulo e Maceió, totalizando 9 diferentes agregados reciclados por britagem.

Os produtos gerados são listados a seguir:

a) Agregado graúdo $(-25,4+4,8 \mathrm{~mm})$ e miúdo $(-4,8 \mathrm{~mm})$ produzidos a partir de britador de mandíbulas;

b) Agregado graúdo $(-25,4+4,8 \mathrm{~mm})$ e miúdo $(-4,8 \mathrm{~mm})$ produzidos a partir de britador de impacto.
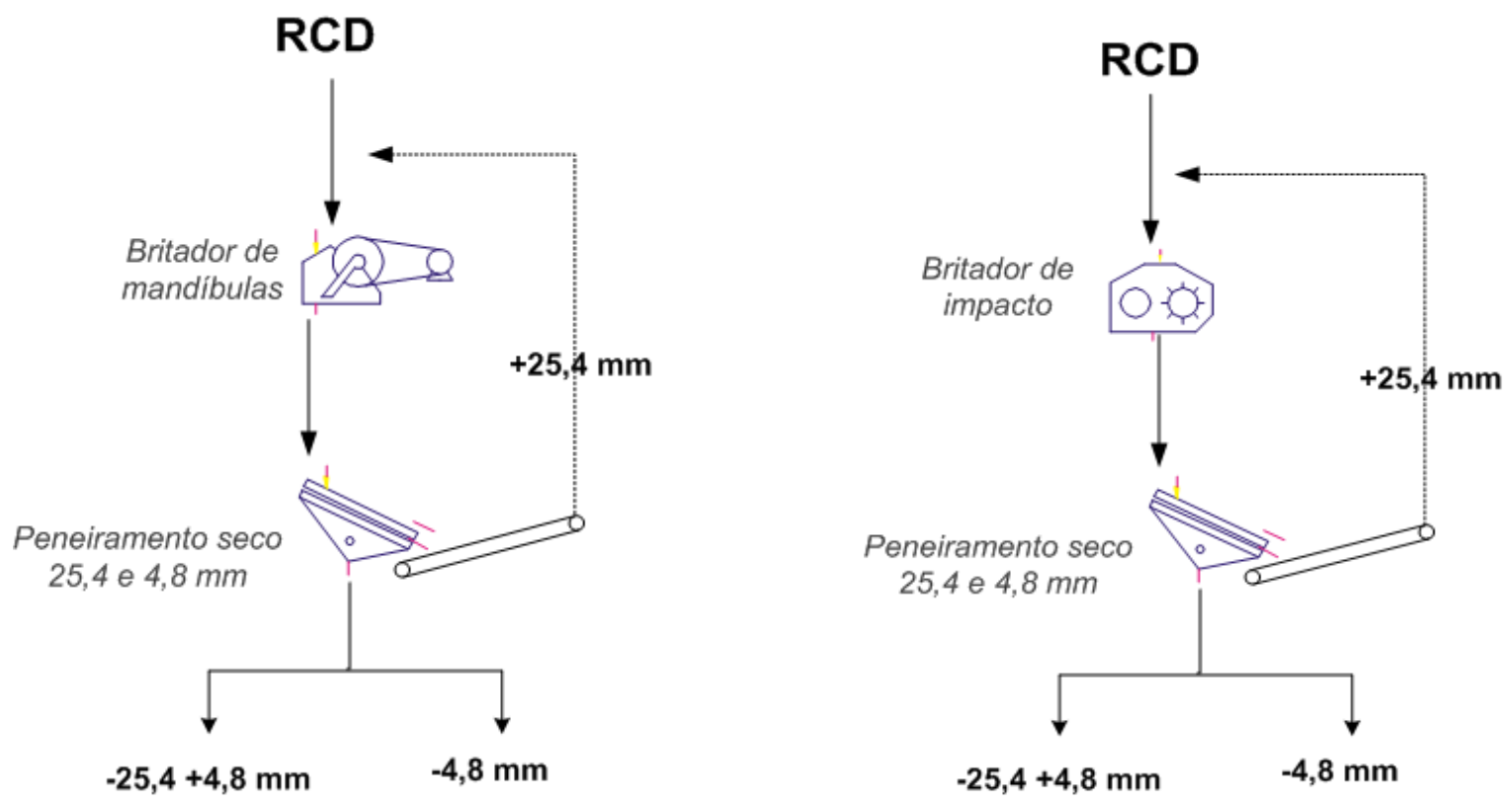

Figura A.2 - Re-processamento do RCD para cada grupo de qualidade, para cada origem de RCD.

Para cada tipo de agregado reprocessado, foi tomada uma alíquota de $100 \mathrm{Kg}$. Os ensaios de britagem foram realizados em circuito fechado com peneira de $25,4 \mathrm{~mm}$, o que significa que todos os produtos estão abaixo dessa malha. Posteriormente cada agregado foi peneirado em 4,8 mm (conforme fluxograma) e então determinado o balanço de massa e a qualidade dos produtos produzidos.

Os britadores utilizados foram:

- Britador de mandíbulas, modelo 2015 (marca Metso; 7ª), com abertura de mandíbula na posição fechada de 1 1/2"; 
- Britador de Impacto, modelo 60605 (marca Metso; 7b) com velocidade de 1.200 rpm e 4 martelos/fileira.

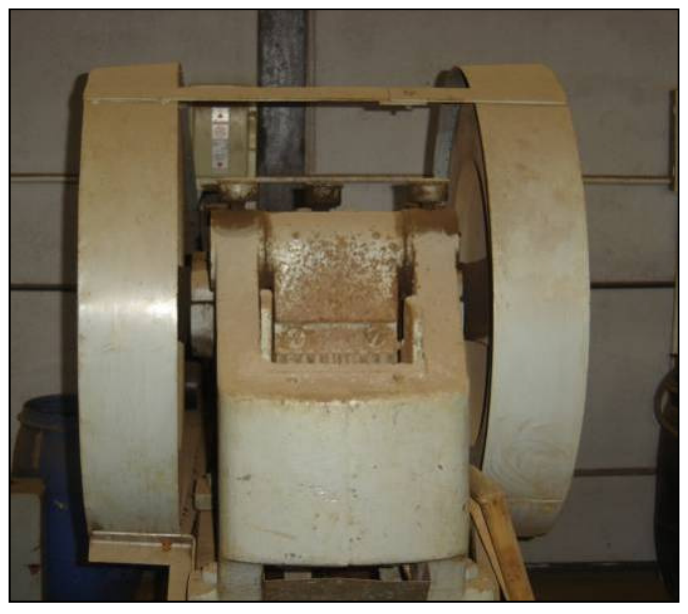

(a)

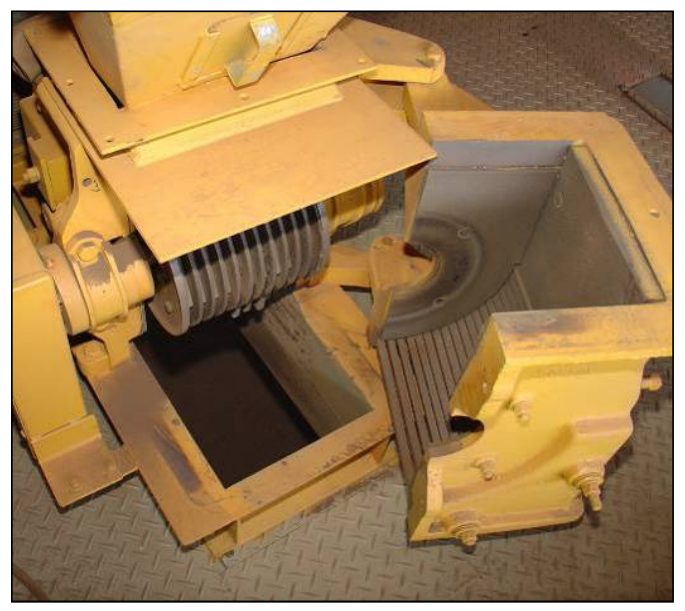

(b)

Figura A.3 - Fotografias dos britadores de mandíbulas (a) e impacto (b) utilizados.

Cada um dos agregados produzidos foi caracterizado para avaliação da qualidade conforme procedimento descrito a seguir.

\section{A.3 CARACTERIZAÇÃO DO AGREGADO GERADO PELO PROCESSAMENTO}

Os agregados graúdos obtidos pelo reprocessamento foram caracterizados de forma semelhante à realizada para os resíduos antes do processamento. Foram avaliadas as seguintes propriedades: teor de contaminantes, distribuição granulométrica, distribuição de densidade e propriedades físicas. As propriedades foram avaliadas para a fração graúda $(+4,8 \mathrm{~mm})$. Para cortes na densidade mencionada utiliza-se 0 cone de meio denso com polpa de ferrosilício em escalas de laboratório para simulações de operações industriais de jigagem. Além das diferenças físicas dos equipamentos, a eficiência em uma operação industrial não é a mesma da obtida em laboratório, o que pode ser corrigido por estimativas de perdas de recuperação (ineficiência da separação). 